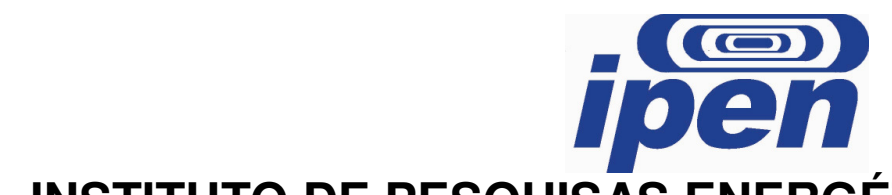

INSTITUTO DE PESQUISAS ENERGÉTICAS E NUCLEARES

Autarquia associada à Universidade de São Paulo

\title{
MUDANÇAS CLIMÁTICAS NO CONTEXTO DAS CIÊNCIAS E DA DIVULGAÇÃO CIENTíFICA
}

\author{
LILIAN DE OLIVEIRA BUENO
}

Dissertação apresentada como parte dos requisitos para obtenção do Grau de Mestre em Ciências na Área de Tecnologia Nuclear - Materiais.

Orientador:

Dr. Afonso Rodrigues de Aquino 
INSTITUTO DE PESQUISAS ENERGÉTICAS E NUCLEARES Autarquia associada à Universidade de São Paulo

\title{
MUDANÇAS CLIMÁTICAS NO CONTEXTO DAS CIÊNCIAS E DA DIVULGAÇÃO CIENTíFICA
}

\author{
LILIAN DE OLIVEIRA BUENO
}

Dissertação apresentada como parte dos requisitos para obtenção do Grau de Mestre em Ciências na Área de Tecnologia Nuclear - Materiais.

Orientador:

Dr. Afonso Rodrigues de Aquino 
Aos meus pais Luiz (in memoriam) e laci, meus primeiros professores, por seus ensinamentos, por sua capacidade de lutar, perserverar e amar, por sua lição de vida, enfim. Aos meus filhos, Diego e Ísis, fonte de inspiração, com quem aprendo todos os dias. 


\section{AGRADECIMENTOS}

Aos meus pais, pelos valores fundamentais que me transmitiram, pelo amor incondicional que sempre me acompanha aonde quer que eu esteja.

Ao meu orientador, Prof. Dr. Afonso Rodrigues de Aquino, decisivo para o desenvolvimento do mestrado, para as superações, motivação necessária e perseverança nas várias etapas. Para sempre levarei comigo tudo que aprendi com ele, seu carinho, seu apoio, seus conselhos e as palavras que me fizeram acreditar ser possível concretizar esta pesquisa.

Ao Ipen, pela oportunidade de desenvolver este trabalho.

À professora Dra. Martha Marques Ferreira Vieira, com quem tanto aprendi sobre metodologia da pesquisa científica, pelo convívio, ensinamentos, atenção e disponibilidade de sempre. Suas revisões e comentários sempre sensatos e inteligentes contribuíram com a qualidade deste trabalho.

Ao professor doutor José Luiz Proença, da ECA/USP, pela participação na banca examinadora, por seus comentários e valorosa discussão suscitada.

Aos professores das disciplinas de Fundamentos em Tecnologia Nuclear, pelo aprendizado. Aos professores doutores Álvaro Carneiro, Gaianê Sabundjian, Luiz Antonio Mai, Luciana Vanni Gatti, do Ipen, por contribuírem com minha formação de maneira tão especial. Carneiro, com suas críticas e contribuições durante o seminário de área, foi muito importante para o aprimoramento desta dissertação, e como membro da banca examinadora foi extremamente cuidadoso e criterioso. Um exemplo de profissional.

Aos professores doutores José Goldemberg e Oswaldo Lucon, que ministraram a disciplina Energia, Desenvolvimento e Meio Ambiente, no IEE/USP, e ao professor doutor Carlos Celso do Amaral e Silva, que ministrou a disciplina Avaliação, Comunicação e Gerenciamento de Riscos Ambientais, na Faculdade de Saúde Pública da USP, todos muito importantes na minha formação como pósgraduanda.

À doutora Ana Maria Pinho Leite Gordon, pelas sugestões e contribuições no exame de capacidade.

Aos participantes da pesquisa que realizei entre indivíduos do público, cientistas e jornalistas. 
Não posso esquecer a amizade de lliene Nunes, o incentivo e o carinho decisivos ao longo desta jornada. José Patricio Náhuel Cárdenas foi outro amigo fiel que em vários momentos me trouxe muitas contribuições pessoais e acadêmicas. À amiga Silvana Massan, pelo incentivo.

Ao citar meus queridos amigos de sempre Edvaldo Paiva, Margarete Bustos, Walkíria Gomes e Sérgio Tavares agradeço a todos do Ipen. Um agradecimento especial aos amigos e excelentes profissionais da biblioteca do instituto.

Aos meus sogros Nestor e Maria e cunhadas Solange e Sandra, por sua preocupação e ajuda em vários momentos importantes. À família Aleman, em especial à Isabel, pelos comentários, pela avaliação crítica e pelas valiosas dicas acadêmicas.

À minha irmã Eliane, por me ajudar com o banco de dados que organizei para o trabalho, e ao meu irmão Luiz Antonio, brilhante profissional da área de matemática e informática, pelo auxílio na elaboração dos gráficos e na editoração, além da revisão das apresentações. Aos meus cunhados Marcio e Luciane, igualmente irmãos queridos, por seu carinho e apoio. Aos meus lindos sobrinhos Caroline, Lucas e Matheus, filhos amados, por encherem meu coração de esperança. Mais um agradecimento à minha mãe, pela imensa ajuda, especialmente na etapa final, por seu apoio incondicional e auxílio com minha pequena. Sem esse auxílio, esta dissertação não teria sido concluída.

Ao meu marido Rodrigo Bueno. Aos meus filhos, Diego e Ísis, por alimentarem minha esperança em um futuro melhor para esse planeta.

As dificuldades pelas quais passamos só tornam maiores as conquistas. E é assim que encerro mais essa etapa, cheia de alegria e com ainda maior gosto pelos desafios.

A todas as pessoas que de uma forma ou de outra fizeram parte desta pesquisa, minha gratidão e um pouco do meu coração com vocês. 
"Os desafios para a criação de modelos sustentáveis de vida humana, mais equânimes na justiça e nas benesses, não poderão ser vencidos por cientistas pensando em separado, produzindo sem vinculações, como o que o conhecimento acadêmico fragmentado gerou nos últimos cinqüenta anos. A interdisciplinaridade e a transdisciplinaridade, longe de uma utopia, surgem como uma grande meta, uma exigência natural para a sobrevivência da espécie humana, se ela quiser continuar sua escalada. Acreditamos que, por meio da adoção de uma ética global, do resgate e da criação de novos valores humanos, possamos criar as condições essenciais para que isso aconteça. Os humanos precisam somar esforços, saberes e conquistas. Pode ser um sonho, mas as possibilidades existem"

\footnotetext{
${ }^{1}$ Genebaldo Freire Dias, no livro "Educação Ambiental - princípios e práticas”. Op. Cit.
} 


\title{
MUDANÇAS CLIMÁTICAS NO CONTEXTO DAS CIÊNCIAS E DA DIVULGAÇÃO CIENTÍFICA
}

\author{
Lilian de Oliveira Bueno
}

\section{RESUMO}

A abordagem do tema mudanças climáticas por dois jornais diários e duas revistas semanais de informação em 2006 e 2007 e a percepção deste tema por formadores de opinião constituem o tema central deste trabalho. Uma pesquisa de campo foi realizada com assinantes dos jornais Folha de S. Paulo e O Estado de S. Paulo e das revistas Veja e Época, com jornalistas desses veículos e com cientistas da área de mudanças climáticas. Mostrou-se elevado o interesse do público pelos temas de ciência, em geral, e meio ambiente em particular. Nos periódicos analisados foram detectados conceitos incorretos do ponto de vista técnico e a cobertura voltou-se principalmente às pesquisas que mostravam impactos das mudanças climáticas. Segurança energética, outro fator fortemente relacionado à questão climática, orientou a pesquisa exploratória em busca de aferir a relação percebida pelo público entre mudanças climáticas e energia nuclear. Também pode ser traçado um paralelo entre o colapso ambiental e a catástrofe nuclear, presente no imaginário popular desde as explosões das bombas atômicas em Hiroshima e Nagasaki. Considerando o papel das ciências de modo geral, é imprescindível destacar que a melhor pesquisa não pode estar dissociada da comunicação eficiente e eficaz, capaz de mobilizar os cidadãos e sensibilizar tomadores de decisão. O diálogo entre cientistas e público, saberes tradicionalmente compartimentados, pode e deve ser praticado e a imprensa tem um papel fundamental neste processo. 


\title{
CLIMATE CHANGE AS SEEN BY SCIENCE AND SCIENTIFIC DISSEMINATION
}

\author{
Lilian de Oliveira Bueno
}

\begin{abstract}
The climate change approach by two daily newspapers and two weekly magazines in 2006 and 2007, and this theme perception by opinion-makers, constitute the major target of this work. A survey was conducted with subscribers to Folha de S. Paulo and O Estado de S. Paulo newspapers, Veja and Época magazines, with their journalists, as well as with climate change scientists. The survey showed that is equally high the public interest in general science subjects and in specific environmental themes. In the analyzed periodicals, some incorrect technical concepts were detected and the press coverage focused, mainly, on research into climate change impacts. Energy security, another factor strongly related to climate, was explored by the research to evaluate public view of a relation between climate change and nuclear energy. A parallel may be made between climate change and nuclear catastrophe, present in the popular imaginary, since the atomic bomb explosions in Hiroshima and Nagasaki. Considering the science role in general, it is essential to highlight the fact that the state of the art research should not be dissociated from efficient and effective communication, able to mobilize citizens and touch decision-makers. Although the dialogue between scientists and the public was considered, traditionally, as related to separated fields of awareness, it may be achieved and the media has a fundamental role in this process.
\end{abstract}




\section{SUMÁRIO}

Página

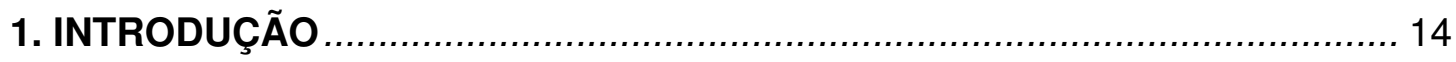

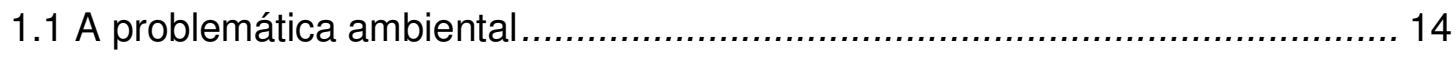

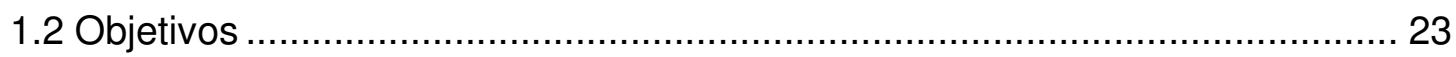

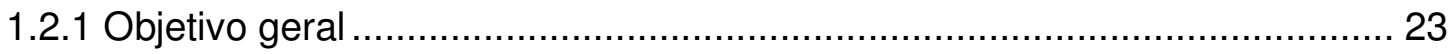

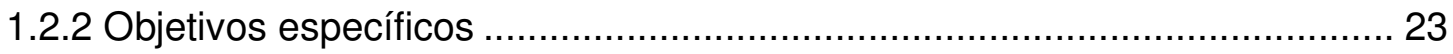

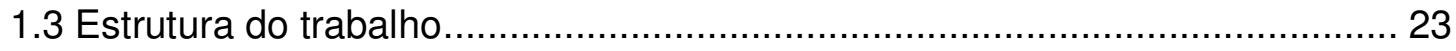

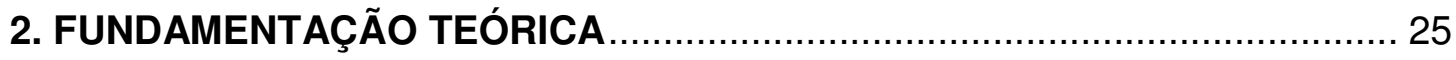

2.1 Meio ambiente e desenvolvimento ......................................................... 25

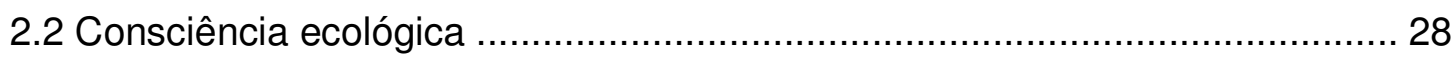

2.3 Importância da Educação Ambiental..................................................... 30

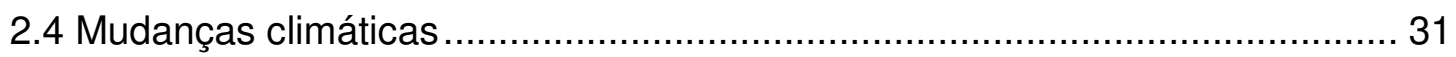

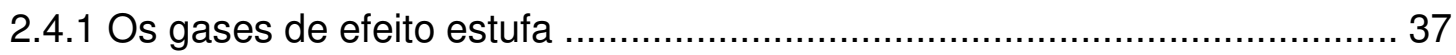

2.4.2 A crise climática e as negociações internacionais .................................... 43

2.4.3 Adaptação e mitigação.................................................................... 50

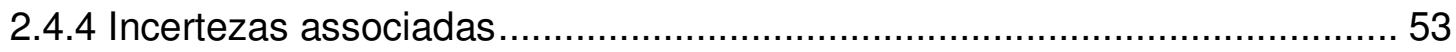

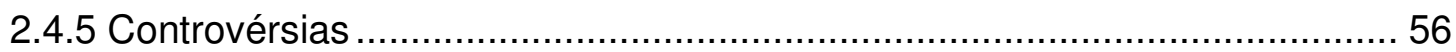

2.5 Segurança energética e mudanças climáticas .......................................... 59

2.6 Energia nuclear e mudanças climáticas ................................................... 64

2.7 A mediação dos meios de comunicação .................................................. 65

2.8 Abordagem do tema mudanças climáticas na imprensa.............................. 68

2.9 Percepção pública sobre meio ambiente e mudanças climáticas ................... 71

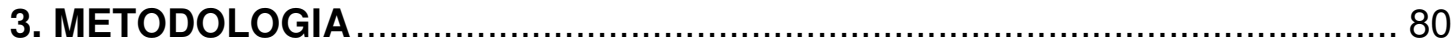

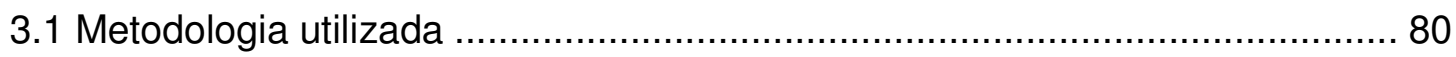

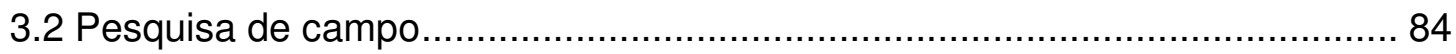

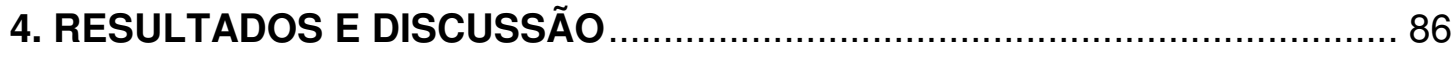

4.1 Informação científica na imprensa ..................................................... 86

4.1.1 Análise de textos jornalísticos sobre mudanças climáticas ......................... 86

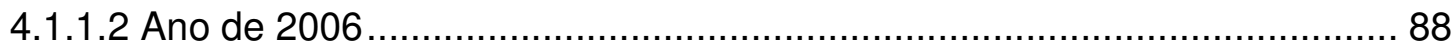

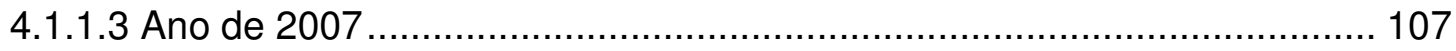

4.1.1.4 Resumo geral ........................................................................... 145 


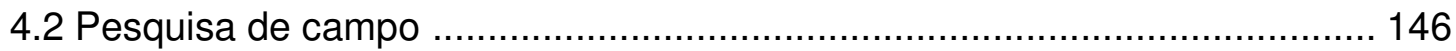

4.2.1 Questionamento aos cientistas .................................................. 146

4.2.2 Questionamento aos jornalistas .................................................... 158

4.2.3 Questionário destinado ao público ................................................. 164

4.2.3.1 Perfil dos participantes ................................................................ 164

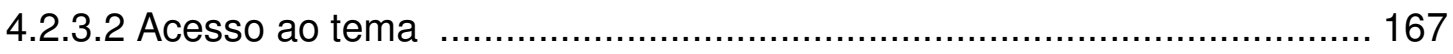

4.2.3.3 Interesse por temas científicos e ambientais ...................................... 168

4.2.3.4 Conceitos científicos e senso comum .............................................. 171

4.2.3.5 Sobre o combate à mudança do clima ................................................. 174

4.2.3.6 Energia nuclear em pauta ............................................................... 181

4.2.3.7 Participação real e participação ideal ................................................ 188

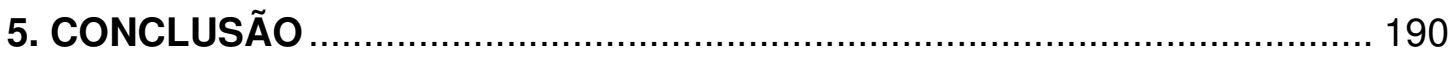

6. TRABALHOS FUTUROS ............................................................ 198

APÊNDICE A - Questionário destinado aos cientistas ............................ 199

APÊNDICE B - Questionário destinado aos jornalistas ............................ 201

APÊNDICE C - Questionário destinado ao público ................................. 202

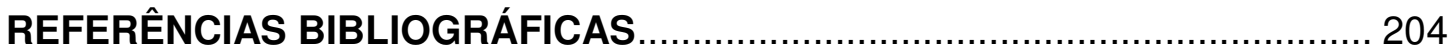




\section{LISTA DE TABELAS}

TABELA 1.1 - População mundial estimada em 2008 e 2009 por região

TABELA 2.1 - Proporção de municípios, por condição de esgotamento sanitário,

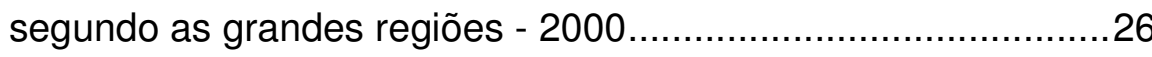

TABELA 2.2 - Taxa de aumento populacional e de aumento das emissões de $\mathrm{CO}_{2}$ entre 1950 e 2005

TABELA 4.1 - Textos sobre mudanças climáticas da editoria de Ciência da FSP em 2006

TABELA 4.2 - Textos sobre mudanças climáticas da editoria Vida\& de OESP em 2006

TABELA 4.3 - Textos sobre mudanças climáticas da editoria Ciência da FSP em 2007 108

TABELA 4.4 - Textos sobre mudanças climáticas da editoria Vida\& de OESP em 2007 120

TABELA 4.5 - Respostas dos cientistas sobre temas das entrevistas 155

TABELA 4.6 - Respostas do público sobre principal meio de acesso a informações sobre o tema mudanças climáticas 168

TABELA 4.7 - Palavras associadas ao tema mudanças climáticas 175 


\section{LISTA DE FIGURAS}

FIGURA 2.1 - Componentes do sistema climático, seus processos e

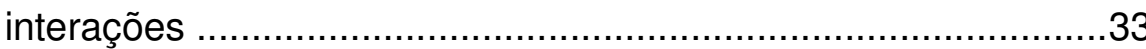

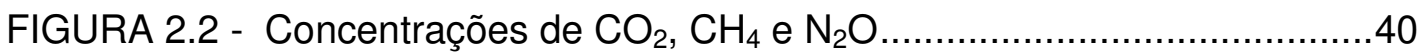

FIGURA 2.3 - Principais componentes da forçante radioativa entre 1750 e 2005

FIGURA 2.4 - Países que mais investiram em energia limpa em 2009 e expansão de investimentos nesse segmento de 2004 a 2009....63

FIGURA 4.1 - Página de reportagem da revista Veja de 08/02/2006 ...............100

FIGURA 4.2 - Capa da revista Veja de 21/06/2006 ......................................102

FIGURA 4.3 - Capa da revista Veja de 11/04/2007 ......................................136

FIGURA 4.4 - Capa da revista Época de 05/02/2007 …...............................142

FIGURA 4.5 - Textos da editoria Vida\& (OESP) - anos de 2006 e 2007 .........145

FIGURA 4.6 - Textos da editoria Ciência (FSP) - anos de 2006 e 2007 ..........145

FIGURA 4.7 - Textos publicados em 2006 e 2007 - principais editorias ..........146

FIGURA 4.8 - Perfil dos participantes quanto ao sexo ...................................165

FIGURA 4.9 - Perfil dos participantes quanto à formação..................................166

FIGURA 4.10 - Perfil dos participantes quanto à faixa etária ..........................166

FIGURA 4.11 - Perfil dos participantes quanto à assinatura de periódicos......167

FIGURA 4.12 - Interesse por temas relacionados à ciência - Homens ..............169

FIGURA 4.13 - Interesse por temas relacionados à ciência - Mulheres.............169

FIGURA 4.14 - Interesse por questões ambientais - Homens ………..............170

FIGURA 4.15 - Interesse por questões ambientais - Mulheres .........................170

FIGURA 4.16 - Ações de combate às mudanças climáticas - Brasil .................177

FIGURA 4.17 - Ações de combate às mudanças climáticas - Mundo ................179

FIGURA 4.18 - Associação entre energia nuclear e mudanças climáticas ......182

FIGURA 4.19 - Participantes que desconhecem associação entre energia nuclear e mudanças climáticas (Grupo 1) 182

FIGURA 4.20 - Participantes que consideram energia nuclear como alternativa (Grupo 2) 185

FIGURA 4.21 - Participantes que consideram que energia nuclear gera mudanças climáticas (Grupo 3). 
FIGURA 4.22 - Participantes que não responderam de forma direta à questão (Grupo 4)

FIGURA 4.23 - Participação ideal versus participação real com relação à conscientização sobre mudanças climáticas - Homens 188

FIGURA 4.24 - Participação ideal versus participação real com relação à conscientização sobre mudanças climáticas - Mulheres............189

FIGURA 4.25 - Participação ideal versus participação real com relação à conscientização sobre mudanças climáticas - Comparativo .....189 


\section{LISTA DE ABREVIATURAS E SIGLAS}

ABNT - Associação Brasileira de Normas Técnicas

AIEA - Agência Internacional de Energia Nuclear

ANDI - Associação Nacional dos Direitos da Infância

CFCs - Clorofluorcarbonetos

COP - Conferência das Partes

COPPE - Coordenação dos Programas de Pós-Graduação em Engenharia

EUA - Estados Unidos da América

GEE - Gases de efeito estufa

HCFCs - Hidroclorofluorcarbonos

IAC - InterAcademy Council

IBGE - Instituto Brasileiro de Geografia e Estatística

IDH - Índice de Desenvolvimento Humano

INPE - Instituto de Pesquisas Espaciais

IPCC - Painel Intergovernamental sobre Mudanças Climáticas

LBA - Large Scale Biosphere-Atmosphere Experiment in Amazônia

LNCC - Laboratório Nacional de Computação Científica

MCT - Ministério da Ciência e Tecnologia

MDL - Mecanismo de Desenvolvimento Limpo

OCDE - Organização para a Cooperação e o Desenvolvimento Econômico

ONG - Organização não-Governamental

ONU - Organização das Nações Unidas

PIB - Produto Interno Bruto

PNUD - Programa das Nações Unidas para o Desenvolvimento

PNUMA - Programa de Meio Ambiente das Nações Unidas

UFAL - Universidade Federal de Alagoas

UNESCO - Organização das Nações Unidas para a Educação, a Ciência e a Cultura

UNFCCC - Convenção-Quadro das Nações Unidas sobre Mudança do Clima USP - Universidade de São Paulo

WMO - World Meteorological Organization

WEC - World Energy Council 


\section{INTRODUÇÃO}

\subsection{A problemática ambiental}

Degradação ambiental e desafios gigantescos em termos de qualidade de vida. A sociedade atual enfrenta turbulências causadas por seu modelo de desenvolvimento baseado no lucro, no consumismo, no desrespeito ao semelhante. Ao mesmo tempo em que o progresso científico e tecnológico foi determinante para diversos avanços das sociedades, levou a ameaças capazes de inviabilizar a continuidade da espécie humana.

Os problemas ambientais foram desencadeados pelo uso predatório dos recursos naturais, a partir de um modelo que depende de um suprimento contínuo e inesgotável de matéria e energia que são utilizadas e devolvidas ao meio ambiente (Braga et al., 2005). Alertam diversos autores que, se o modelo de desenvolvimento da sociedade não for alterado, a humanidade caminha para 0 colapso.

Conforme destaca Morais citando Grün, a explosão da primeira bomba atômica no deserto de Los Alamos, Novo México, em 1945, e os bombardeios às cidades de Hiroshima e Nagasaki plantaram as primeiras sementes do ambientalismo contemporâneo (Grün, 2001 apud Morais, 2004).

O livro "Primavera Silenciosa", da bióloga Rachel Carson, em 1962, chama atenção de forma marcante para o problema causado pela utilização de pesticidas, principalmente o DDT, na agricultura. Voltado ao grande público, conquista atenção para $\circ$ problema por referir-se à ausência do canto dos pássaros na primavera, uma imagem profundamente emotiva que se somou à narrativa apontando os danos da substância para o homem e para os ecossistemas. A substância, cancerígena e bioacumulativa, foi banida na maioria dos países na década de 1970. A publicação contribuiu para aumentar a consciência do público com relação aos impactos ambientais causados pelas atividades humanas.

$\mathrm{Na}$ discussão sobre os problemas ambientais da atualidade, não se

pode deixar de abordar alguns grandes marcos para a área ambiental: a Conferência da Biosfera (UNESCO), em 1968, com a criação do Clube de Roma, grupo que atuou no sentido de catalisar mudanças globais, alertando para os limites do crescimento (título de um relatório publicado em 1972 em mais de trinta 
idiomas e que alcançou enorme repercussão mundial); a Conferência de Estocolmo, em 1972, com o conceito de ecodesenvolvimento e a criação pela Organização das Nações Unidas (ONU) do Programa das Nações Unidas para o Meio Ambiente (PNUMA), no mesmo ano, em Nairóbi, África. A Primeira Conferência das Nações Unidas sobre o Meio Ambiente ou Conferência de Estocolmo, como ficou conhecida, deixou registrada a importância estratégica na busca pela qualidade de vida, conforme lembra Morais (Morais, 2004). Os 113 países reunidos nesta conferência discutiram a importância da educação para mudanças profundas nos modelos de desenvolvimento, nos hábitos e comportamentos dos indivíduos e da sociedade. Dessa época surge o rótulo Educação Ambiental como um novo processo (Dias, 2004).

Destaca Morais que a crise do petróleo em 1973 serve de impulso à área nuclear e marca a identidade dos movimentos ecológicos. Ainda na década de 1970, ocorre em Londres a publicação do Manifesto pela sobrevivência creditando à industrialização e aos valores consumistas a responsabilidade pela degenerescência do meio ambiente. No que diz respeito à educação ambiental, em 1975 ocorre em Belgrado um workshop contando com a participação de 65 países e uma conferência intergovernamental sobre o tema em 1977, em Tibilisi, Geórgia (Morais, 2004).

Constituem ainda marco na área ambiental: o relatório sobre desenvolvimento sustentável "Nosso Futuro Comum", editado em 1987 pela Comissão Mundial do Desenvolvimento e Meio Ambiente sob a coordenação da então primeira-ministra da Noruega Gro Brundtland; a entrada em vigor no mesmo ano do Protocolo de Montreal, para eliminar a produção e o uso de substâncias potencialmente destruidoras da camada de ozônio; a conferência Rio-92, realizada na cidade do Rio de Janeiro em 1992, com a publicação da Agenda 21 , contendo alertas sobre problemas ambientais; a Conferência Rio+5, em 1997 e a Conferência Rio+10, em 2002. Dentre os resultados da Rio-92, surgiu a Agenda 21, instrumento de política que traz ações prioritárias para os países se comprometerem em prol de soluções para os problemas sócio-ambientais, e o embrião para o Protocolo de Quioto, principal mecanismo mundial para conter as emissões dos gases de efeito estufa (GEE). Também foram criados dois dos mais importantes Acordos Multilaterais Internacionais: as Convenções do Clima e da Biodiversidade. 
Um papel primordial das políticas e leis é a conciliação de todos os aspectos do desenvolvimento econômico, proteção ambiental e inclusão social. A legislação ambiental mundial trouxe marcos históricos, como a Lei do Ar Puro, adotada na Inglaterra em 1956, em virtude dos problemas de poluição em Londres, e em 1970 nos EUA. Em 1977, foi verificado o aparecimento de buracos na camada de ozônio sobre a Antártica e, em 1983, foi registrada uma redução da ordem de $50 \%$ do ozônio, fato repetido em 1985. Com a assinatura do Protocolo de Montreal, em 1987, foi estabelecido um cronograma para interrupção do consumo e banimento das substâncias responsáveis pela depleção da camada de ozônio, os CFCs. O documento foi ratificado por 188 países e sofreu cinco emendas nos anos de 1990. O acordo é um exemplo de sucesso no atingimento de metas.

A Conferência da ONU sobre Meio Ambiente e Desenvolvimento Rio92, ao chamar atenção para o combate à degradação do planeta e estabelecer a Agenda 21, trouxe avanços importantes no combate aos problemas ambientais. Dentre os 27 princípios estabelecidos, vários autores destacam especialmente os seguintes:

- Princípio do poluidor pagador, em que o custo das medidas deve estar contido no custo dos bens e serviços que causam a poluição;

- Princípio da prevenção, especialmente para as atividades perigosas;

- Princípio das responsabilidades comuns, porém diferenciadas, cujo exemplo são as discussões envolvendo mudanças climáticas e redução de emissões dos GEE;

- Princípio da tutela pública do meio ambiente, em que cabe ao Governo defender o bem de uso comum (Goldemberg e Lucon, 2008).

Goldemberg frisa que as mudanças denominadas antropogênicas eram insignificantes antes da Revolução Industrial, no final do século XIX, mas se tornaram preocupantes devido ao aumento populacional e ao uso excessivo de recursos, notadamente os energéticos, principalmente nos países industrializados. A natureza, do ponto de vista econômico, é tanto fornecedora de matériasprimas como receptora de rejeitos danosos. 
Barbieri lembra que os problemas ambientais são anteriores à revolução industrial. Houve devastação de florestas e perda de fertilidade do solo em muitas áreas, mas a poluição gerada, confinada em áreas específicas, era absorvida com mais facilidade, pois se constituía basicamente de matéria orgânica (Barbieri, 2007).

De acordo com dados das Nações Unidas², a população mundial corresponde a aproximadamente 6,8 bilhões de habitantes, com mais de $80 \%$ vivendo em regiões menos desenvolvidas, devendo chegar a 9,1 bilhões em 2050 (TAB. 1.1). A atividade industrial é responsável por emissões de gases de efeito estufa que correspondem a 900 bilhões de toneladas de dióxido de carbono, tendo 450 bilhões permanecido na atmosfera. Cerca de $80 \%$ das emissões é causada pela industrialização, uso do solo e desmatamento. A queima de combustíveis fósseis já ocasionou um aumento de 0.758 graus Celsius na temperatura média do planeta e elevação de 22 centímetros do nível do mar durante o século XX (IPCC, 2007).

TABELA 1.1 - População mundial estimada em 2008 e 2009 por região (em milhares)

\begin{tabular}{lcc}
\hline Região & Ano de 2008 & Ano de 2009 \\
\hline Mundo & 6750062 & 6829360 \\
\hline África & 987092 & 1009893 \\
\hline Ásia & 4075309 & 4121097 \\
\hline Europa & 731568 & 732206 \\
\hline América Latina e Caribe & 576102 & 582418 \\
\hline América do Norte & 345053 & 348360 \\
\hline Oceania & 34937 & 35387 \\
\hline
\end{tabular}

Fonte - Department of Economic and Social Affairs of the United Nations Secretariat (2009)

O desenvolvimento desordenado, sem planejamento, teve como consequências níveis crescentes de poluição e degradação ambiental. Com a qualidade do ar comprometida, somando-se a poluição das águas e solos, foram significativos os impactos na saúde das pessoas. A tecnologia que contribui para reversão de situações críticas também tem seus limites:

\footnotetext{
2 United Nations. World Population Prospects: The 2008 Revision. Disponível em: <http://unstats.un.org/unsd/demographic/products/vitstats/serATab1.pdf>
} 
"Métodos de planejamento, modelos matemáticos, equipamentos para controle de poluição e processos tecnológicos alternativos menos poluentes foram desenvolvidos. Isso possibilitou a correção de problemas existentes, como também a estimativa antecipada de efeitos e impactos de situações hipotéticas futuras por meio de simulações com modelos físicos e matemáticos. Passou-se, assim, a admitir que existem limites que devem ser respeitados e que a tecnologia é fundamental, mas não é capaz de resolver todos os problemas quando alguns limites, às vezes desconhecidos, são alcançados (efeito estufa, depleção da camada de ozônio)" (Braga et al., 2005).

Braga lembra ainda que o conceito de desenvolvimento sustentável, proposto pela Comissão Mundial do Desenvolvimento e Meio Ambiente no relatório "Nosso Futuro Comum”, em 1987, requer melhor especificação do ponto de vista prático. De acordo com o autor, o conceito - que preconiza o atendimento das necessidades da geração presente sem comprometer a habilidade das gerações futuras de atender as suas próprias necessidades - seria um ato de fé ou um desejo filosófico de preservação. Braga afirma que a expressão necessidades futuras envolve um grau de subjetividade, posto que existe a questão do grau de desenvolvimento da região ou país em questão. Certamente os parâmetros válidos para um país como o Japão não são os mesmos para um país da África Oriental, com consumo de energia próximo a $2.000 \mathrm{kcal} /$ dia (Braga et al., 2005).

Goldemberg destaca que a população mundial de aproximadamente 6 bilhões de habitantes consome em média oito toneladas de recursos minerais por ano, movimentando algo em torno de 48 bilhões de toneladas. Há um século essa população era de 1,5 bilhões e o consumo menor do que duas toneladas per capita, com impacto dezesseis vezes menor (Goldemberg e Lucon, 2008).

Dias lembra que a sociedade humana, empurrada por padrões de consumo insustentáveis, experimenta um profundo colapso de ética e valores humanísticos, verificável em suas atitudes diárias, permitindo o crescimento da corrupção, a corrosão da democracia e o alargamento do fosso entre ricos e pobres.

"Afugentou-se a gente do campo e as cidades se tornaram superpovoadas, imersas em problemas crônicos de saneamento e serviços, abrigando hordas de desempregados, subnutridos, doentes e analfabetos em favelas, regadas a drogas, prostituição e violência" (Dias, 2004). 
Com as alterações ambientais, a crise foi agravada, promovendo mudanças consideráveis. Goldemberg pondera que a presença do homem na Terra é bastante recente em termos geológicos e depende de condições ambientais bastante específicas: clima, temperatura, presença de água e de outras formas de vida. Distúrbios além desses limites, mesmo com a notável capacidade de adaptação, são por demais perigosos (Goldemberg e Lucon, 2008).

Crescendo além de sua capacidade de suporte, as cidades não conseguem mais arcar com seus custos de manutenção. A Terra estaria exibindo sintomas evidentes de um limite crítico na sua resiliência ecossistêmica, ou seja de sua resposta ou capacidade de se recuperar das tensões que the foram impostas (Dias, 2002).

Nesse contexto, surge o desafio das mudanças globais do clima, causadas pela ação do homem. Os países mais afetados serão os que menos contribuíram para o problema. De acordo com o IPCC, painel das Nações Unidas sobre mudanças climáticas, a temperatura do planeta deve aumentar de 1,8 a $4^{\circ} \mathrm{C}$ até o final do século 21 e o nível do mar deve sofrer elevação entre 18 e $59 \mathrm{~cm}$. Eventos climáticos extremos vão se tornar mais frequentes (IPCC, 2007).

Goldemberg destaca que para se identificar as políticas necessárias a fim de evitar a degradação ambiental, pode-se avaliar o custo da reparação dos danos causados ou o custo de se evitar o problema. A comparação pode ajudar a decidir sobre a ação mais conveniente ou mais efetiva. Para mitigação, os custos são em geral menores, mas é preciso assumir o risco de causar o impacto sabendo que o poluidor não será cobrado na íntegra pelo ocorrido. Este enfoque pode ser aplicado a qualquer problema ambiental (Goldemberg e Lucon, 2008).

Vários economistas estudaram os custos dos danos provenientes das mudanças climáticas. O britânico Sir Nicholas Stern publicou um relatório em 2006, a respeito do tema - "Review on the Economics of Climate Change". Algumas conclusões, listadas por Goldemberg e Lucon, são apresentadas a seguir, de forma resumida:

- Ainda há tempo para evitar os piores impactos das mudanças climáticas;

- As diferentes análises de custos e riscos concluem que a ação intensa e pronta, de longe, é melhor do que não agir; 
- Os custos e riscos das mudanças climáticas equivalerão a perdas anuais de $5 \%$ do PIB global permanentemente, podendo chegar a $20 \%$, considerando maiores impactos e riscos;

- Os custos das ações de mitigação de emissões podem se limitar a cerca de $1 \%$ do PIB global ao ano;

- Os investimentos nos próximos 10-20 anos terão um efeito profundo no clima do planeta a partir de 2050;

- Os impactos econômicos serão de proporções similares aos das últimas grandes guerras e da crise de 1929, porém impossível de reverter as tendências;

- A concentração de GEE poderá dobrar dos níveis pré-industriais até 2035 , com aumento na temperatura média acima de $2^{\circ} \mathrm{C}$;

- No longo prazo, há chances de mais de $50 \%$ de exceder $5^{\circ} \mathrm{C}$;

- Mesmo níveis moderados de aquecimento global terão sérios impactos na renda mundial, na vida humana e no meio ambiente;

- A adaptação é essencial e deve ser acelerada, de forma a se criar resiliência e reduzir custos para as mudanças que ocorrerão nos próximos 20 anos e que não podem ser mais revertidas;

- Em países em desenvolvimento a adaptação custará bilhões de dólares todo ano e trará mais pressões sobre os recursos escassos;

- Os custos de estabilização são significativos mas gerenciáveis, enquanto o atraso é perigoso e muito mais caro;

- A estabilização entre 450 e 550 ppm de $\mathrm{CO}_{2}$ eq requer reduções de emissões de pelo menos 25\% abaixo dos níveis atuais até 2050 e talvez algo como $80 \%$;

- Muito difícil estabilizar as concentrações em 450 ppm;

- Estabilizar concentrações entre 500 e 550 ppm custaria 1\% do PIB global, se houver ação imediata;

- Custos podem ser menores se houver ganho em eficiência;

- Custos serão mais altos se tecnologias demorarem a ser incorporadas e os políticos falharem em colocá-las em prática; 
- A distribuição dos custos das ações será desigual, mas mesmo se os países ricos cortarem 60 a $80 \%$ até 2050, os países em desenvolvimento precisam adotar medidas significativas;

- O setor de eletricidade deverá se descarbonizar em pelo menos $60 \%$ até 2050 (para 500 ppm) e serão necessários profundos cortes no setor de transportes;

- Mesmo com renováveis e outras tecnologias com pouco carbono, as fontes fósseis preencherão pelo menos metade de toda a energia primária de 2050;

- Carvão continuará sendo importante e a captura e sequestro de $\mathrm{CO}_{2}$ na fonte é fundamental;

- Cortes nas emissões industriais, agrícolas e combate ao desmatamento são essenciais.

- São necessários para uma resposta efetiva: dar um preço ao carbono por taxas, comércio ou regulamentos; apoio à inovação e desenvolvimento de novas tecnologias e remoção de barreiras à eficiência energética; informação e educação sobre as mudanças climáticas (Stern, 2006 apud Goldemberg e Lucon, 2008).

No que diz respeito à redução de emissões, há ações em curso; algumas delas, ambiciosas. As bases de cooperação estão expressas na Convenção do Clima e no Protocolo de Quioto. Vale destacar que, embora sejam importantes as ações individuais, estas não são suficientes e tornou-se urgente uma visão internacional sobre metas de longo prazo.

O relatório Stern também pontua como elementos-chave:

- O comércio de emissões;

- Metas ambiciosas de mitigação de emissões;

- Cooperação tecnológica internacionalmente coordenada;

- Ações para diminuir o desmatamento;

- Adaptação e assistência ao desenvolvimento, principalmente voltadas aos mais pobres;

- Mecanismos de financiamento internacional.

Vale lembrar ainda que a adaptação é uma medida complementar mas não alternativa - à mitigação. Goldemberg explica que há muitos benefícios 
em se evitar as mudanças climáticas através da conservação de energia, troca de combustíveis e captura de $\mathrm{CO}_{2}$ por meio do reflorestamento (Goldemberg e Lucon, 2008). Várias são as estimativas de custos para as opções. O IPCC levantou estudos para diferentes países sobre custos da estabilização das emissões.

O Relatório de Desenvolvimento Humano 2007/2008 do PNUD apresenta a proposta de cortar as emissões em pelo menos 80\% até 2050; investir anualmente um adicional de pelo menos U\$ 86 bilhões em esforços de adaptação, a fim de proteger os mais pobres do mundo, apoiando a produção de biocombustíveis sem prejudicar os direitos dos pequenos agricultores ou populações indígenas; e apoiando os esforços para reduzir o desmatamento de florestas em países como o Brasil. No relatório é sugerido que, com o apoio de tais medidas e através de uma cooperação financeira internacional e tecnologia de baixo carbono, países em desenvolvimento também deveriam participar, cortando suas emissões em 20\% até 2050 (PNUD, 2008).

O meio ambiente tem sua capacidade de assimilar agressões de agentes poluidores. Para evitar a degradação ambiental, são estabelecidos limites, porém mesmo se forem atendidos todos os padrões de emissão, o meio pode não suportar o aumento da poluição. Explica Goldemberg que se torna então necessário um gerenciamento pela qualidade, que pode ter mecanismos como metas de redução baseadas em inventários e compensação de emissões entre processos (Goldemberg e Lucon, 2008).

A redução da poluição pode ser preventiva, para evitar os danos, ou reparatória. No primeiro caso, enquadram-se as tecnologias mais limpas. No segundo caso, estão os acidentes ambientais. O custo é sempre um fator a se considerar, lembrando que este decresce ao longo do tempo.

Diante de tanta informação, números, argumentos, estudos, cenários, merece destaque a observação de Silva, no prefácio ao livro de Trigueiro:

"Necessitamos, em primeiro lugar, comunicar nossas idéias em linguagem mais simples e direta, capaz de envolver mais gente. Precisamos também de algum recolhimento para elaborar melhor a relação entre as idéias e a prática. Achar maneiras de transformar o conhecimento em fazeres, em tecnologia, em substituição de coisas e comportamentos. Nesses tempos de informação rápida, superficial e excessiva, sem recolhimento para avaliar e processar, restará o consumo: das novidades, dos 
tratados, das declarações sem compromisso" (SILVA, M., 2002 In: Trigueiro, A. (Coord.), 2002).

\subsection{Objetivos}

\subsubsection{Objetivo geral}

O objetivo geral deste trabalho é analisar como o tema mudanças climáticas foi apresentado ao grande público entre os anos de 2006 e 2007 pela grande imprensa, verificando como esse público percebe o fenômeno e suas implicações e assimila o conhecimento adquirido, a partir de uma pesquisa com leitores das publicações analisadas e um grupo seleto de jornalistas e cientistas.

\subsubsection{Objetivos específicos}

1. Verificar o interesse do público em temas relacionados à ciência e meio ambiente.

2. Verificar como o tema mudanças climáticas tem sido compreendido pelo grande público.

3. Analisar a percepção do público pesquisado com relação ao combate a um dos principais problemas da atualidade na área ambiental.

4. Analisar a relação entre o tema mudanças climáticas e a energia nuclear, a partir da percepção deste público.

\subsection{Estrutura do trabalho}

$\mathrm{Na}$ introdução, são apresentadas questões referentes à problemática ambiental, visando a compreensão do tema e suas implicações, além dos objetivos desta pesquisa.

No segundo capítulo, são abordados conceitos relacionados à sustentabilidade, ecologia e a importância da educação ambiental. Para melhor entendimento do tema central, mudanças climáticas, foram explicitados os principais conceitos envolvidos, como o que são gases de efeito estufa, a adaptação e mitigação, controvérsias sobre a crise climática e incertezas associadas, além das negociações internacionais que norteiam os processos 
decisórios. Segurança energética é outra discussão essencial do capítulo, que traz à tona a relação das fontes renováveis em geral e da energia nuclear em particular como resposta ao desafio de enfrentar as mudanças climáticas globais. A mediação realizada pelos meios de comunicação e os desafios desta abordagem também são introduzidos neste segundo capítulo.

$\mathrm{Na}$ terceira parte, são apresentadas a metodologia para seleção e análise das notícias veiculadas nos periódicos selecionados para este estudo e para a pesquisa de campo realizada com o público de assinantes dos jornais e revistas analisados e com o grupo de cientistas e jornalistas.

O quarto capítulo apresenta os resultados e discussão dos dados obtidos a partir dos textos jornalísticos analisados e a partir das entrevistas realizadas com jornalistas, cientistas e público de assinantes dos jornais Folha de S. Paulo, O Estado de S. Paulo e revistas Veja e Época. A pesquisa com assinantes foi realizada com 108 voluntários.

O capítulo seguinte apresenta as conclusões do estudo e o último capítulo traz sugestões para trabalhos futuros. Ao final, são apresentados os modelos de questionários aplicados aos cientistas, aos jornalistas e ao público. 


\section{FUNDAMENTAÇÃO TEÓRICA}

\subsection{Meio ambiente e desenvolvimento}

Alguns autores conceituam a qualidade de vida no planeta como dependente do equilíbrio entre três elementos: população, recursos naturais e poluição (Braga et al., 2004). Vários são os enfoques possíveis quando se trata de conceituar e discutir temas relacionados ao desenvolvimento.

De acordo com Goldemberg, as abordagens mais importantes seriam a econômica, social e ambiental. Relacionando desenvolvimento econômico e consumo de energia, explica o autor, há caminhos que possibilitam o desenvolvimento da sociedade sem um aumento correspondente desse consumo. Há evidências históricas nos países desenvolvidos e nos países em desenvolvimento vem ocorrendo o mesmo, a chamada redução da intensidade energética. Países retardatários no processo de industrialização, como o Japão, atingiram pico de intensidade energética menor do que seus predecessores, indicando adoção anterior de processos industriais e tecnologias inovadoras e modernas, energeticamente mais eficientes (Goldemberg e Lucon, 2008).

Entre os indicadores utilizados para se medir o grau de desenvolvimento econômico de um país está o PIB, que é o total de bens e serviços produzidos, entretanto outros índices são utilizados como medida de desenvolvimento. Um desses índices é o IDH, que engloba indicadores sociais, como longevidade, grau de instrução e padrão de vida. Desigualdades na distribuição de renda podem ser comparadas pelo índice Gini, que mede o quanto a renda ou o consumo entre indivíduos se desvia da condição ideal, igualitária. Diversos outros indicadores foram criados posteriormente e contemplam outras dimensões, incluindo a ambiental. Segundo o IBGE, no caso brasileiro, o desafio de construir indicadores capazes de caracterizar e subsidiar o processo de desenvolvimento sustentável soma-se à exigência de expressar a diversidade característica do país (IBGE, 2010).

Com a finalidade de medir a sustentabilidade do planeta, surgiu o conceito de pegada ecológica. A pegada ecológica mede a área correspondente de terra bioprodutiva e ecossistemas aquáticos necessários para produzir os recursos utilizados e para assimilar os resíduos produzidos por uma dada população, sob um determinado estilo de vida. 
Vale lembrar que dois terços da população mundial não têm acesso aos confortos da civilização moderna. O progresso do século $X X$ baseou-se na exploração dos combustíveis fósseis, que além de acarretarem graves distúrbios ambientais para este século, somam-se os problemas geopolíticos para se obter esses recursos (Goldemberg e Lucon, 2008).

O Brasil é um país que ainda tem muitos desafios a enfrentar. Um exemplo é o acesso a condições de serviços fundamentais, como saneamento básico. Em pleno século XXI, 47,8\% dos municípios brasileiros ainda não dispõem de coleta de esgoto, situação bem distante de atingir uma condição satisfatória. Conforme a TAB. 2.1, a Região Norte é a que possui a maior proporção de municípios sem coleta (92,9\%), seguido do Centro-Oeste (82,1\%), Sul $(61,1 \%)$, Nordeste $(57,1 \%)$ e Sudeste $(7,1 \%)$. Os municípios que têm apenas serviço de coleta superam aqueles que coletam e tratam o esgoto $(32,0 \%$ e $20,2 \%$, respectivamente). No Sudeste, a região do país com a maior proporção de municípios com esgoto coletado e tratado, somente um terço deles apresenta uma condição adequada de esgotamento sanitário.

TABELA 2.1 - Proporção de municípios, por condição de esgotamento sanitário, segundo as Grandes Regiões - 2000 (em porcentagem)

\begin{tabular}{lccc}
\hline \multicolumn{1}{c}{ Região } & Sem coleta & Só coletam & Coletam e tratam \\
\hline Brasil & $\mathbf{4 7 , 8}$ & $\mathbf{3 2 , 0}$ & $\mathbf{2 0 , 2}$ \\
\hline Norte & 92,9 & 3,5 & 3,6 \\
\hline Nordeste & 57,1 & 29,6 & 13,3 \\
\hline Sudeste & 7,1 & 59,8 & 33,1 \\
\hline Sul & 61,1 & 17,2 & 21,7 \\
\hline Centro-Oeste & 82,1 & 5,6 & 12,3 \\
\hline
\end{tabular}

Fonte: IBGE - Pesquisa Nacional de Saneamento Básico 1989/2000 (IBGE, 2002)

Os indicadores do IBGE mostram que, entre 1989 e 2000, o serviço de saneamento nos municípios cresceu em apenas $10 \%$ e o esforço maior se voltou à ampliação do tratamento do esgoto coletado. A cobertura do serviço de esgotamento sanitário é reduzida e o tratamento do esgoto coletado não é abrangente. Nos distritos brasileiros que não dão nenhum tipo de tratamento ao esgoto produzido $(66,2 \%)$, o esgoto é despejado in natura nos corpos de água ou no solo, comprometendo a qualidade da água utilizada para o abastecimento, 
irrigação e recreação. Do total de distritos que não tratam o esgoto sanitário coletado, a grande maioria (84,6\%) despeja o esgoto nos rios, sendo os distritos das regiões Norte e Sudeste os que mais se utilizam desta prática $(93,8 \%$ e $92,3 \%$, respectivamente). No Brasil, ao mesmo tempo em que se discute legislação moderna e eficiente, não se obteve êxito em proporcionar condições dignas de saneamento básico a toda a população.

No que se refere às políticas para reduzir a degradação ambiental, Goldemberg explicita que a combinação otimizada dos programas de ação depende em última instância do contexto institucional dos países, de suas atividades específicas e da aceitação política dessas medidas. Essa combinação possui diversas variáveis. A continuidade das políticas é apontada como algo fundamental.

Vargas afirma que o processo de globalização "é uma nova fase pela qual está passando o sistema capitalista mundial, envolvendo aspectos monetários, financeiros, patrimoniais, tecnológicos, culturais e ambientais, e que irão influir decisivamente na ordem econômica que aos poucos se afirma." Continua o autor afirmando que o problema não está na insustentabilidade do atual padrão de desenvolvimento do sistema, mas no próprio sistema, já que a lógica do mercado, a financeirização da riqueza, sob a forma monetária pode ser tudo menos sustentável. Propõe ainda as seguintes questões:

"É possível conciliar o "socialmente equitativo", o "ambientalmente equilibrado" e o "economicamente eficiente e produtivo"? É possível se definir novas prioridades ao ensino e à pesquisa, passando da perspectiva da produtividade para a perspectiva da preservação dos recursos naturais? Como construir verdadeiros indicadores de sustentabilidade? Como tratar, e aqui o fundamental, no mesmo nível, as questões técnicas, ambientais, políticas e sociais?" (Vargas, 2002).

Almeida afirma que o caminho ideal a ser seguido passa pela gestão democrática da diversidade, sem perder de vista o conjunto da sociedade. $A$ direção do desenvolvimento sustentável deixa de ser linear e única, para se tornar um modelo rico em alternativas, capaz de enfrentar com novas soluções a crise social e ambiental.

"É preciso conceber um desenvolvimento que tenha nas prioridades sociais sua razão-primeira, transformando, via participação política, excluídos e marginalizados em cidadãos. Esta me parece uma verdadeira chance para a reorganização 
conseqüente da sociedade, visando a sustentação da vida e a

manutenção de sua diversidade plena" (Almeida, 2002).

Os problemas ambientais podem ocorrer nos níveis local, regional e global. Nas resoluções de problemas ambientais locais, estão envolvidos a esfera imediata de governo, os agentes privados e públicos do local e os cidadãos. No nível regional, são as regiões como metrópoles e áreas circunvizinhas, juntamente com as comunidades do entorno e órgãos públicos e privados da região, que estão relacionados aos problemas. Goldemberg lembra que a poluição regional tem que ser tratada no nível estadual, nacional e eventualmente entre países. Em âmbito global, estão os problemas como a destruição da camada de ozônio, mudanças climáticas, perda da biodiversidade, desertificação.

\subsection{Consciência ecológica}

A palavra "ecologia" deriva do grego oikos, no sentido de "casa", e logos, que significa "estudo". A ecologia é a ciência que estuda todas as relações entre os organismos atuais e os ambientes envolventes, a distribuição dos organismos nestes ambientes, bem como a natureza das suas interações ${ }^{3}$. Ecologia é comumente utilizada como sinônimo de meio ambiente.

O Primeiro Relatório Nacional para a Convenção sobre a Diversidade Biológica, produzido pelo Ministério do Meio Ambiente, mostra que o Brasil possui $20 \%$ da diversidade biológica da Terra, a flora mais rica (aproximadamente 22\% do total mundial), $10 \%$ dos anfíbios e mamíferos, $17 \%$ das aves, mais de três mil espécies de peixes de água doce e de cinco a dez milhões de insetos. Também abriga o país a maior floresta remanescente, a Mata Atlântica, o Pantanal de Mato Grosso, biomas costeiros e marinhos, o cerrado e a caatinga (Braga et al., 2005).

Dentre tantas discussões sobre o meio ambiente e como disciplinar o acesso a bens e serviços ambientais, várias têm sido as tentativas de responder a esse questionamento. No campo da economia, duas correntes de pensamento são evidentes: a economia do meio ambiente e dos recursos naturais e a economia ecológica. Na primeira, o indivíduo compra do poder público o que se denomina direito de uso do ambiente. Na segunda linha de pensamento, a economia seria um subsistema da atividade humana e subordinado às leis que

3 IBGE, 2004. Vocabulário Básico de Recursos Naturais e Meio Ambiente. Disponível em http://www.ibge.gov.br/home/presidencia/noticias/vocabulario.pdf 
regem os ecossistemas da biosfera. E contesta os princípios e mecanismos de mercado para valoração dos bens e serviços econômicos.

"Os esforços de convergência entre as duas escolas têm dado alguns resultados, pelo menos no intercâmbio entre os muitos conceitos da economia ecológica (e mais especificamente da ecologia) e a abordagem econômica neoclássica do ambiente. Estão, entretanto, ainda distantes de produzir uma integração entre si e uma abordagem econômica do ambiente em condições de inseri-lo na economia real com todas as nuances que 0 caracterizam." (Braga et al., 2005)

Reigota apresenta a postura da ciência aliada ao desenvolvimento numa perspectiva ecologista. $O$ desenvolvimento de estudos sobre a biodiversidade envolvendo profissionais de áreas como a botânica, antropologia ecológica dentre outras e membros de comunidades de indígenas ou agricultores permite troca de conhecimentos institucionalizados com aqueles transmitidos através da tradição e costumes. É um exemplo de como os conhecimentos sistematizados podem se beneficiar do conhecimento popular ou étnico e também o contrário. O estudo de espécies possibilita aplicações medicinais ou nutricionais ao mesmo tempo em que se preserva o ecossistema. Desse diálogo, cientistas e aqueles que exploram economicamente esses conhecimentos não devem ser os únicos beneficiados. As comunidades locais onde se situam os recursos naturais seriam favorecidas, por meio de acesso aos resultados, parceria autoral na difusão, pagamento pelo know-how, parcela nos lucros obtidos (Reigota, 2002).

Também observa que a síntese entre o local e o global permite à ciência voltar-se ao enfoque ecológico. Algumas palavras características da ciência clássica ou moderna seriam, de acordo com o autor, harmonia, equilíbrio, descoberta, objetividade, racionalidade, dados quantitativos. Enquanto a ciência pós-moderna apresenta um vocabulário que reflete o novo contexto: dúvida, desordem, incerteza, caos, probabilidade, fragmentos, auto-organização, sistema longe do equilíbrio, interpretação, dados qualitativos, diálogo.

A economia não pode mais ser vista como um sistema dissociado da natureza, uma vez que as sociedades humanas não podem sobreviver sem o clima da baixa atmosfera, sem a água e os recursos da litosfera, sem a fotossíntese e ação microbiana no solo (Reigota, 2002).

Então, é necessário ter clareza que, para a economia da sustentabilidade, os conceitos e métodos usados na ciência econômica devem 
levar em conta as restrições que a dimensão ambiental impõe à sociedade. Esta, por sua vez, deve estar organizada para que a troca de matéria e energia com a natureza não transgrida certas leis. Portanto, visando não só proteger o meio ambiente, mas também promover o desenvolvimento, a economia e a ecologia devem integrar-se nos processos decisórios (Rampazzo, 2002).

\subsection{Importância da Educação Ambiental}

Conforme especialistas em educação ambiental, os avanços da ciência e da tecnologia precisam estar a serviço da educação, que tem o papel fundamental de ajudar a criar consciência e promover melhor compreensão dos problemas que afetam o meio ambiente.

Dias afirma que a Educação Ambiental deve dirigir-se a pessoas de todas as idades, a todos os níveis, na educação formal e não-formal. Os meios de comunicação social têm a responsabilidade de estar a serviço dessa missão educativa (Dias, 2004).

Entre as recomendações da Conferência Intergovernamental sobre Educação Ambiental aos Países Membros, ocorrida em Tbilisi, em 1977, a de número 1, em suas alíneas "c" e "d", explicita:

- "Um objetivo fundamental da educação ambiental é lograr que os indivíduos e a coletividade compreendam a natureza complexa do meio ambiente natural e do meio criado pelo homem, resultante da integração de seus aspectos biológicos, físicos, sociais, econômicos e culturais, e adquiram os conhecimentos, os valores, os comportamentos e as habilidades práticas para participar responsável e eficazmente da prevenção e solução dos problemas ambientais, e da gestão da qualidade do meio ambiente.

- O propósito fundamental da educação ambiental é também mostrar, com toda clareza, as interdependências econômicas, políticas e ecológicas do mundo moderno, no qual as decisões e comportamento dos diversos países podem ter conseqüências de alcance internacional. Nesse sentido, a educação ambiental deveria contribuir para o desenvolvimento de um espírito de responsabilidade e de solidariedade entre os países e as regiões, como fundamento de uma nova ordem internacional que garanta a conservação e a melhoria do meio ambiente" (Conferência Intergovernamental de Tbilisi, 1977 apud Dias, 2004).

Com os esforços de organismos internacionais, como a UNESCO e o

PNUMA, houve intercâmbio de informações e difusão de ideias novas a respeito de educação ambiental. 
$\mathrm{Na}$ mesma conferência, ficou registrada a necessidade de programas de Educação Ambiental que sensibilizem o público com relação ao seu ambiente, envolvendo-o na resolução dos problemas da sociedade.

Com relação à educação e informação na área ambiental, a Conferência de Moscou, em 1987, sugeriu:

- "Elaboração de programas educativos relativos aos meios de comunicação, essenciais para desenvolver nos indivíduos maior capacidade para analisar e avaliar a natureza, os objetivos e propósitos das informações. Ao mesmo tempo será necessário melhorar a qualidade das mensagens que dependem, em grande parte, do conhecimento e do grau de sensibilização do comunicador, e promover a cooperação entre cientistas e comunicadores;

- Utilização dos novos meios de comunicação e dos métodos pedagógicos ativos;

- Criação de um banco de programas audiovisuais;

- Desenvolvimento e uso de museus. Museus regionais, museus de história natural e ecomuseus desempenham um papel importante na integração sistemática de experiências e novos dados ambientais, na apresentação de materiais e na educação do público, bem como dos estudantes e professores" (Dias, 2004).

A Educação Ambiental é encarada como agente catalisador de mudanças, pelo seu caráter interdisciplinar e por abordar a questão ambiental em todos os seus aspectos, sócio-culturais, políticos, científico-tecnológicos, éticos, ecológicos. Otimizando novos processos educativos, deve levar a caminhos diferentes, com melhoria do ambiente e da qualidade de vida.

\subsection{Mudanças climáticas}

As mudanças climáticas são um dos principais problemas ambientais da atualidade e têm mobilizado cientistas, ambientalistas, políticos, indivíduos do público. Com a divulgação do último relatório do IPCC, em 2007, a discussão climática ganhou maior visibilidade.

A conclusão-chave, que sustenta todo o material produzido nos relatórios, é a de que as mudanças climáticas já estão ocorrendo e que são resultado de atividades humanas. Em 2007, foi publicado um relatório-síntese contendo os achados dos três grupos de trabalho ("The Physical Sciences Basis", "Impacts, Adaptation and Vulnerability" e "Mitigation of Climate Change"). Mais de 500 autores e 2.000 revisores trabalharam no último relatório-síntese, que passou pelo aval de delegados de mais de 100 nações participantes. 
O IPCC foi criado em 1988, pela World Meteorological Organization (WMO) e pelo PNUMA. Em 2007, foi publicado o quarto relatório do painel do clima, resultante de cada um dos três grupos de trabalho, os quais se dedicam a estudar e compilar informações científicas disponíveis sobre mudanças climáticas; impactos ambientais e sócio-econômicos das mudanças climáticas e formulação de estratégias de resposta. Além dos relatórios de avaliação, o IPCC também disponibiliza relatórios especiais e publicações técnicas sobre temas específicos. Os relatórios resultam de um consenso dos cientistas da área climática e conselheiros governamentais de todo o mundo.

Uma das questões em discussão sobre as mudanças do clima é como identificar se de fato o mundo está ficando mais quente e qual seria a origem dessa alteração.

É importante destacar que o sistema climático é complexo e envolve várias interações. Muitos dos processos ainda dependem de exaustiva pesquisa para melhor compreensão. Segundo a WMO, o clima é definido como a média das condições meteorológicas da temperatura, precipitação e velocidade dos ventos em um período de trinta anos. Ar, água, gelo, terra e vegetação, assim como a interação entre esses elementos compõem o sistema climático. Além da dinâmica interna desse sistema, há forçantes externas, como por exemplo a circulação atmosférica e oceânica ou eventos como El Niño, fenômeno que implica no aquecimento das águas do Pacífico na costa do Peru e Equador, devido a flutuações do padrão de pressão atmosférica (Barros, 2008). Essas forçantes podem ser naturais, como variações da energia emitida pelo sol, ou provocadas pelo homem (antrópicas), como mudanças no uso do solo.

Na FIG. 2.1 estão representados os componentes do sistema climático, os processos envolvidos e as interações entre eles, como divulgado pelo IPCC, em seu quarto relatório, chamado AR4. Na seção seguinte, os gases de efeito estufa serão mencionados de forma mais detalhada. 


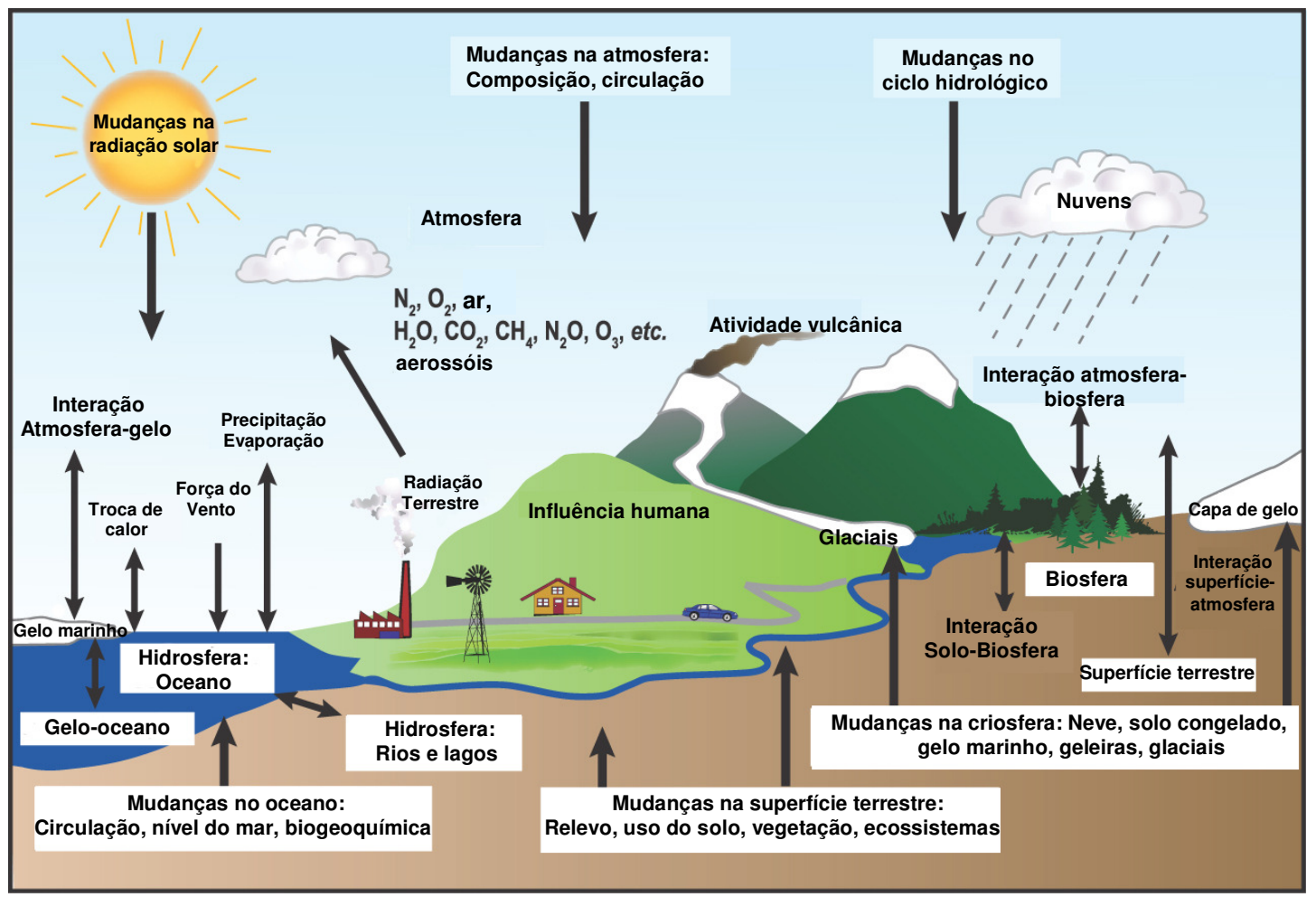

FIGURA 2.1 - Componentes do sistema climático, seus processos e interações

Fonte - IPCC, 2007

Para entender o sistema climático, é preciso diferenciar tempo e clima. O primeiro seria o que vivenciamos de mês a mês e de ano a ano, oscilando constantemente. Clima é a média dessas flutuações ao longo do tempo (Walker e King, 2008).

A energia emitida pelo Sol que chega à atmosfera terrestre pode ser medida em Watts por metro quadrado. Setenta por cento do fluxo de energia é absorvido e reemitido como calor e trinta por cento é refletido, pelas nuvens, pelos aerossóis e em determinadas regiões da superfície terrestre. Do total dessa radiação absorvida, três quartos o são pela superfície e um quarto pelas nuvens e vapor d'água. Com isso a Terra é aquecida. Parte do calor absorvido, ao ser reemitido, é absorvido pelos gases de efeito estufa e emitido para a superfície.

Barros observa que para alterar o balanço radioativo da Terra, de forma a modificar a temperatura de equilíbrio, podem ocorrer basicamente três situações:

- Variação da energia solar incidente por alterações na órbita da Terra e no Sol; 
- Variação na fração de radiação refletida devido a mudanças na cobertura de nuvens ou devido a aerossóis, por exemplo;

- Variação na radiação infravermelha emitida pela Terra devido à alteração no teor dos gases de efeito estufa.

A resposta a essas modificações ocorre de forma direta ou indireta, quando um processo desencadeia outro que influencia o primeiro. Tais mecanismos são conhecidos como mecanismos de retroalimentação, como o vapor d'água - que em maior quantidade amplifica o aquecimento e em menor quantidade provoca mais resfriamento -, ou o efeito causado pelas nuvens ao refletir a radiação solar (promovendo resfriamento da superfície) e ao absorver a radiação emitida pela Terra (promovendo aquecimento), aumentando assim o efeito estufa.

Barros exemplifica que um mecanismo de retroalimentação negativo resulta da radiação emitida pela Terra e a temperatura da superfície. Com o aumento da temperatura, maior fluxo de radiação é emitido, promovendo o resfriamento da superfície. Com isso, a temperatura do planeta se mantém relativamente estável (Barros, 2008).

De acordo com registros de temperatura realizados desde o século $X V I I$ na Inglaterra, pode-se identificar, especialmente no final do século $X X$, aquecimento. As medições mais abrangentes se iniciaram em 1850. No início das medições diretas, as diferentes estações meteorológicas não eram padronizadas. Também há maior número de medições no hemisfério norte do que no hemisfério sul e nos continentes do que no mar. As temperaturas marinhas são medidas desde metade do século XIX. As medições realizadas por estações meteorológicas em número cada vez maior nos continentes e nos oceanos, em balões meteorológicos e dados de satélites proporcionam uma ampla cobertura do planeta.

Já a reconstrução do clima passado (paleoclimatologia) é feita por meio de indicadores naturais, como os anéis de crescimento das árvores de diferentes épocas. Em regiões tropicais, os corais fornecem tais informações e, nas regiões polares, o gelo guarda tais registros. Até mesmo a vegetação fornece pistas dessa temperatura, pelo sedimento acumulado no fundo dos lagos. Ou seja, somados os resultados de pesquisas de todos esses registros indiretos, é possível ter uma ideia de como era o clima no passado (Walker e King, 2008). 
Normalmente nos estudos paleoclimáticos vários indicadores são utilizados simultaneamente (Barros, 2008).

Para representar os processos físicos diretamente envolvidos e mecanismos de realimentação e/ou interação entre os diversos componentes do complexo sistema terra-oceano-atmosfera são utilizados modelos climáticos, programas computacionais que simulam ou analisam a resposta do sistema climático ante uma situação de aumento ou diminuição do fluxo de energia. A chamada resolução espacial de tais modelos tem aumentado. Supercomputadores conseguem fornecer mais detalhes dos elementos climáticos. Nos cálculos são considerados elementos como os processos atmosféricos, física do oceano, formação do gelo marinho, vegetação do planeta. Grandes fontes de incerteza vêm das nuvens, dos aerossóis e da representação do ciclo do carbono.

O quarto relatório do IPCC, de 2007, indica que 11 dos últimos 12 anos (1995 a 2006) figuravam entre os 12 mais quentes do registro de temperatura da superfície global. A tendência linear de aquecimento de 1906 a 2005 indicava $0,74^{\circ} \mathrm{C}$, superior à tendência de aquecimento de $0,6^{\circ} \mathrm{C}$ apresentada no relatório anterior - o terceiro do IPCC, de 2001. No AR4, o aquecimento das últimas décadas foi considerado inequívoco.

Os cientistas concluíram que o aquecimento global é resultado do aumento das emissões de gases de efeito estufa geradas pelas atividades humanas. Alguns cientistas, entretanto, apresentam posição diversa desse consenso e apresentam outros argumentos para refutar essa conclusão principal.

Evidências do aquecimento são várias, como a perda do permafrost (áreas de gelo permanente) e a retração das geleiras alpinas. Muitos dos impactos das mudanças do clima vão aumentar os problemas de desenvolvimento que o mundo já enfrenta. Como se pode inferir, as mudanças climáticas influenciam as condições de vida e também questões de desenvolvimento econômico e social. De acordo com o IPCC, políticas climáticas são mais efetivas quando vinculadas a estratégias sustentáveis de desenvolvimento nacional e regional. Outro ponto é que os países mais pobres, com menos recursos e menor capacidade de adaptação são os mais vulneráveis (IPCC, 2007).

Independente do que seja feito agora para mudar os hábitos de emissão de carbono, os efeitos só serão sentidos várias décadas mais tarde. Isto 
porque os oceanos absorvem a energia advinda da quantidade extra de GEE gradualmente. Ou seja, a escala de tempo envolvida é de décadas ou até séculos (Walker e King, 2008).

As conclusões do IPCC adotam uma terminologia em relação à probabilidade de ocorrência dos eventos:

- Praticamente certo: > 99\% de probabilidade de ocorrer

- Muito provável: > 90\%

- Provável: > 66\%

- Mais provável do que não: > 50\%

- Improvável: <33\%

- Muito improvável: $<10 \%$

- Excepcionalmente improvável: $<1 \%$

O relatório atribui à influência das atividades humanas o aumento do nível do mar durante a última metade do século XX (muito provável); mudanças nos padrões de vento (provável), afetando com relação a tempestades extratropicais e padrões de temperatura; aumento de temperaturas das noites de calor extremo, noites frias e dias frios (provável); aumento do risco de ondas de calor, áreas afetadas por secas desde os anos 1970 e freqüência de eventos de fortes precipitações. Com o aumento do carbono lançado por atividades antropogênicas tem ocorrido, ainda, a acidificação dos oceanos, causando problemas para os ecossistemas aquáticos. Mesmo com práticas de mitigação e de desenvolvimento sustentável, as emissões globais vão continuar a crescer nas próximas décadas. (IPCC, 2007).

Walker e King destacam que o relatório do IPCC é baseado em mais de 29 mil dados de observação distribuídos em 75 estudos e que mostram mudanças significativas em sistemas físicos e biológicos em todo o mundo. Destacam ainda o que os cientistas do clima sempre chamam atenção: de que é sempre difícil relacionar ocorrências específicas com a mudança climática, mas alguns eventos recentes chamam extrema atenção. São situações que mostram como mudanças no clima podem ter um impacto brutal para o ser humano:

- Em Darfur, região ao sul do Saara, "mais de dois milhões de pessoas foram deslocadas, tiveram suas casas destruídas e suas vidas arruinadas". Uma estiagem em meados da década de 1980 
deu início ao conflito, em que foram mortos 400 mil civis. Pastores árabes e fazendeiros africanos se mataram por escassos recursos de água e terras.

- O Furacão Katrina, em 2005, sexto mais forte furacão atlântico registrado provocou mais de 1,8 mil mortes e prejuízos de cerca de US\$80 bilhões. O aquecimento global não deve aumentar o número de furacões, mas os deixará mais intensos.

- As ondas de calor na Europa em 2003 mataram pelo menos 35 mil pessoas (Walker e King, 2008).

\subsubsection{Os gases de efeito estufa}

A superfície da Terra recebe radiações visíveis, uma pequena quantidade de ultravioleta, o infravermelho e ondas de rádio. As radiações ultravioleta são absorvidas pela camada de ozônio que envolve a Terra a uma altitude de aproximadamente 25 quilômetros. As radiações visíveis e o infravermelho são, em grande parte, absorvidos nas camadas intermediárias da atmosfera pela poeira e pelo vapor d'água.

Uma pequena parte da energia incidente na superfície da Terra é utilizada pelos vegetais e potencializada, por meio da fotossíntese, em alimento matéria orgânica. Outra parte é refletida pela nuvens e por partículas suspensas no ar, retornando ao espaço e portanto sendo perdida para a Terra. Este fenômeno, chamado albedo, define-se como a medida da capacidade de um material refletir a luz. A radiação remanescente chega à superfície em forma de luz direta ou difusa na proporção de $10 \%$ de radiação ultravioleta, $45 \%$ radiação visível e 45\% de infravermelho (Braga et al., 2004).

Em publicação do IBGE, o efeito estufa é definido como a capacidade que a atmosfera da Terra apresenta de reter parte da radiação térmica emitida pela superfície do planeta. A luz solar atravessa a atmosfera e após ser interceptada e parcialmente absorvida pelas superfícies sólidas e massas d'água, é reemitida como radiação térmica (calor), que encontra dificuldade para sair da atmosfera. O efeito estufa garante temperaturas mais altas na superfície da Terra, e minimiza as variações diárias e estacionais de temperatura. Sem este fenômeno a temperatura do planeta seria bem mais baixa (IBGE, 2004). 
O carbono é o principal constituinte da matéria orgânica. O ciclo do carbono é perfeito, pois é devolvido ao meio na mesma taxa em que ocorre sua síntese pelos produtores, as plantas e animais em seu processo de respiração.

$\mathrm{Na}$ presença da luz solar, as plantas utilizam o $\mathrm{CO}_{2}$ e o vapor de água para sintetizar compostos orgânicos de carbono, hidrogênio e oxigênio. No processo de respiração, ocorre a liberação da energia armazenada nas moléculas orgânicas. Pela fotossíntese e respiração, o carbono completa seu ciclo biogeoquímico, passando da fase inorgânica à orgânica e vice-versa. Caso haja aumento de $\mathrm{CO}_{2}$ na atmosfera, parte deste $\mathrm{CO}_{2}$ é absorvida pelo oceano, ficando dissolvido na água.

No ciclo principal, produtores, consumidores e decompositores participam dos processos de fotossíntese e respiração. No ciclo secundário, há o decaimento das plantas e animais incorporados por processos geológicos na crosta terrestre. Foram esses organismos transformados em combustíveis fósseis e calcário. Portanto, os combustíveis fósseis são energia solar armazenada na forma de moléculas orgânicas no interior da Terra (Braga et al., 2004).

A partir da Revolução Industrial, com o uso intenso dos combustíveis fósseis, o $\mathrm{CO}_{2}$ passou a ser devolvido à atmosfera em quantidades superiores à capacidade das plantas (fotossíntese) e dos oceanos (reação de difusão) nos seus processos. É este desequilíbrio o responsável pelo incremento do efeito estufa.

Os GEE retêm relativamente pouca radiação solar, enquanto absorvem com maior eficiência a radiação emitida pela superfície da Terra (Xavier e Kerr, 2004). São responsáveis por manter a troposfera aquecida. Entre os principais estão vapor de água, dióxido de carbono $\left(\mathrm{CO}_{2}\right)$, metano $\left(\mathrm{CH}_{4}\right)$, óxido nitroso $\left(\mathrm{N}_{2} \mathrm{O}\right)$, ozônio troposférico $\left(\mathrm{O}_{3}\right)$, hexafluoreto de enxofre $\left(\mathrm{SF}_{6}\right)$ clorofluorcarbonos (CFCs) e hidroclorofluorcarbonos (HCFCs), entre outros. Sem os gases de efeito estufa, a temperatura média estimada na Terra seria de $15^{\circ} \mathrm{C}$ negativos, com tendência de resfriamento (D'Amélio, 2006).

Xavier e Kerr (2004) destacam que a contribuição de um gás para o efeito estufa depende do comprimento de onda no qual ele absorve radiação, de sua concentração, de sua intensidade de absorção por molécula, de quão fortemente os outros gases concorrem com ele nos mesmos comprimentos de onda e do seu tempo de residência na atmosfera. Ressaltam ainda que "o 
balanço energético global do planeta é complexo e a concentração dos gases é apenas um dos componentes que o influenciam".

As emissões dos gases de efeito estufa cresceram, com aumento de $70 \%$ entre 1970 e 2004. Para o $\mathrm{CO}_{2}$ esse aumento foi de 80\% entre 1970 e 2004. Sua principal fonte é o uso de combustíveis fósseis. As mudanças no uso da terra contribuem com uma parcela menor. A remoção do $\mathrm{CO}_{2}$ da atmosfera envolve diferentes processos com escalas de tempo diferentes. Cerca de $50 \%$ será removido da atmosfera dentro de 30 anos, e $30 \%$ será removido dentro de alguns séculos. Os $20 \%$ restantes devem ficar na atmosfera por muitos milhares de anos. Em suma, mesmo que as concentrações fossem estabilizadas, continuariam contribuindo para uma tendência de aquecimento, já que a vida média de alguns gases é longa, ou seja permanecem na atmosfera por um longo tempo (IPCC, 2007).

$\mathrm{O}$ metano $\left(\mathrm{CH}_{4}\right)$ é outro gás de efeito estufa importante, que teve aumento de um valor pré-industrial de cerca de 715 ppb para 1732 ppb no início da década de 90, sendo de 1774 ppb em 2005. A concentração atmosférica de metano em 2005 ultrapassava em muito a faixa natural dos últimos 650.000 anos (320 a 790 ppb). A explicação para o aumento das concentrações do gás está predominantemente na agricultura e no uso de combustíveis fósseis (IPCC, 2007). Pesquisas detectaram emissões de metano pela vegetação.

A concentração atmosférica global de óxido nitroso $\left(\mathrm{N}_{2} \mathrm{O}\right)$ aumentou de um valor pré-industrial de cerca de $270 \mathrm{ppb}$ para $319 \mathrm{ppb}$ em 2005. A taxa de aumento foi aproximadamente constante desde 1980. Mais de um terço de todas as emissões de óxido nitroso é antrópica, devendo-se principalmente à agricultura (IPCC, 2007).

$\mathrm{Na}$ FIG. 2.2 é demonstrado o aumento das concentrações de $\mathrm{CO}_{2}, \mathrm{CH}_{4}$ e $\mathrm{N}_{2} \mathrm{O}$. 


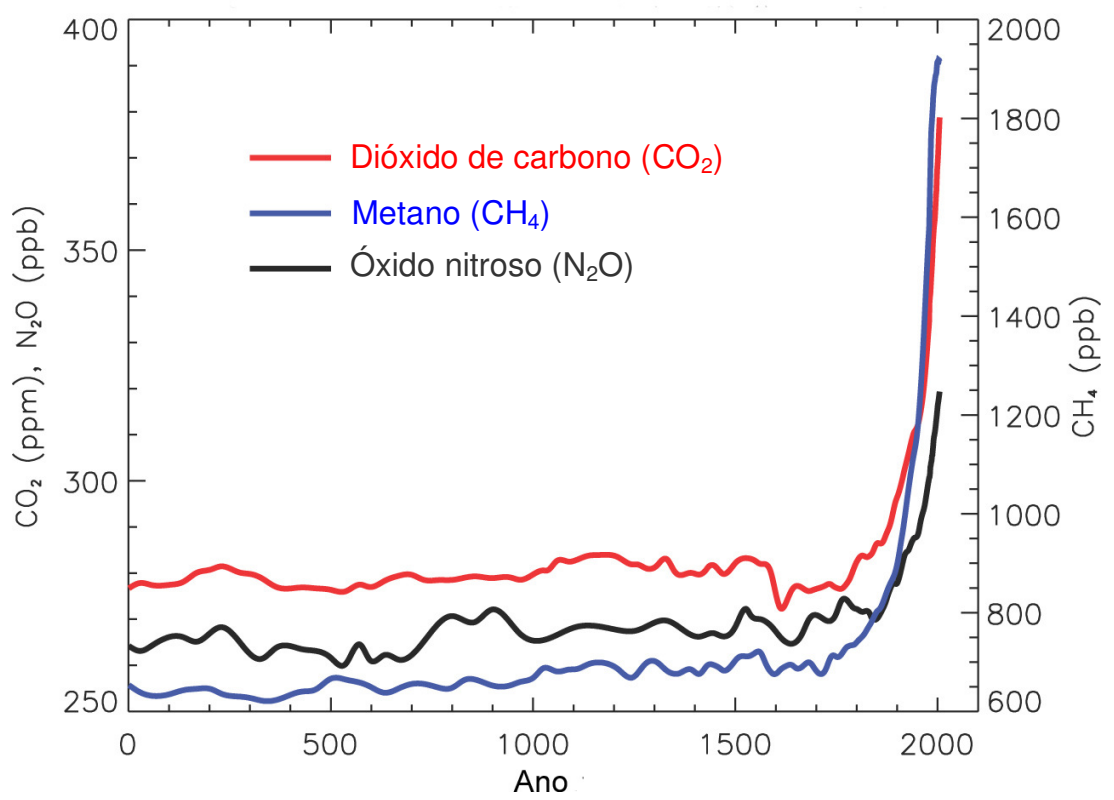

FIGURA 2.2 - Concentrações de dióxido de carbono, metano e óxido nitroso Fonte - IPCC, 2007

Barbieri ressalta que concentrações de metano e de óxido nitroso geram danos maiores do que quantidades equivalentes de $\mathrm{CO}_{2}$. Por conta das quantidades de $\mathrm{CO}_{2}$ lançadas ao longo do tempo por variadas fontes esse gás acabou sendo utilizado como base para medidas. Considerando o tempo médio de permanência dos GEE na atmosfera, o IPCC criou uma medida de potencial de aquecimento global a partir do $\mathrm{CO}_{2}$ como referência. $\mathrm{O} \mathrm{CH}_{4}$ tem potencial de aquecimento 21 vezes maior que o $\mathrm{CO}_{2} \mathrm{e}$ o do $\mathrm{N}_{2} \mathrm{O}$ é 310 vezes maior em relação ao $\mathrm{CO}_{2}$ (Barbieri, 2007).

Satterthwaite (2009) afirma que considerações a respeito das mudanças nas emissões de $\mathrm{CO}_{2}$ nas últimas décadas não podem ser dissociadas do crescimento econômico dos países e os setores onde ocorreu este crescimento, assim como não se pode dissociar as emissões das alterações na renda nacional e sua distribuição. Ao analisar as implicações do crescimento populacional e da urbanização para as mudanças climáticas, demonstra que esse crescimento não impulsiona a mudança climática, mas sim o número de consumidores e seu nível de consumo. A contribuição em termos de emissões pode variar de um fator de mais de 1.000, dependendo das circunstâncias de onde se vive e do estilo de vida. Na TAB. 2.2 é estabelecido um comparativo 
entre o aumento de população e as emissões de $\mathrm{CO}_{2}$ por regiões e nos países com maior incremento em emissões do gás de efeito estufa.

Embora na África Subsaariana tenha havido crescimento populacional de 18,5\% entre 1980 e 2005, as emissões de $\mathrm{CO}_{2}$ aumentaram em 2,4\%. Para a Ásia, o aumento populacional de 63,1\% representou aumento de $82,7 \%$ de emissões de $\mathrm{CO}_{2}$ no mesmo período. Para a Europa, o aumento populacional de $1,8 \%$ equivaleu a decréscimo de $12,6 \%$ em emissões. Na América do Norte, 0 aumento populacional de $4 \%$ foi acompanhado por um aumento de 13,9\% nas emissões e na América Latina e Caribe 9,4\% de aumento populacional equivaleu a incremento de $6,4 \%$ nas emissões. Os países que mais aumentaram suas emissões foram China, EUA, Índia, Coréia e Japão, nessa ordem (WRI e ONU apud Satterthwaite, 2009).

TABELA 2.2 - Taxa de aumento populacional e de aumento das emissões de $\mathrm{CO}_{2}$ entre 1950 e 2005

\begin{tabular}{|c|c|c|c|c|}
\hline \multirow[b]{2}{*}{ Região } & \multicolumn{2}{|c|}{$1980-2005$} & \multicolumn{2}{|c|}{$1950-1980$} \\
\hline & $\begin{array}{c}\text { Crescimento } \\
\text { populacional } \\
(\%)\end{array}$ & $\begin{array}{c}\text { Aumento de } \\
\text { emissões de } \\
\mathrm{CO}_{2}(\%)\end{array}$ & $\begin{array}{c}\text { Crescimento } \\
\text { populacional } \\
(\%)\end{array}$ & $\begin{array}{c}\text { Aumento de } \\
\text { emissões de } \\
\mathrm{CO}_{2}(\%)\end{array}$ \\
\hline África (Norte) & 3,0 & 2,5 & 2,5 & 1,0 \\
\hline África (Subsaariana) & 18,5 & 2,4 & 10,7 & 2,2 \\
\hline Ásia & 63,1 & 82,7 & 64,1 & 30,6 \\
\hline Europa & 1,8 & $-12,6$ & 7,6 & 39,7 \\
\hline América Latina e Caribe & 9,4 & 6,4 & 10,2 & 5,3 \\
\hline América do Norte & 4,0 & 13,9 & 4,4 & 19,9 \\
\hline Oceania & 0,4 & 2,1 & 0,4 & 1,3 \\
\hline \multicolumn{5}{|c|}{$\begin{array}{l}\text { Países com maior incremento populacional e nas emissões de } \mathrm{CO}_{2} \text { : } \\
\text { participação global entre } 1980-2005(\%)\end{array}$} \\
\hline China & 15,3 & 44,5 & & \\
\hline EUA & 3,4 & 12,6 & & \\
\hline Índia & 21,7 & 9,9 & & \\
\hline Coreia do Sul & 0,5 & 3,7 & & \\
\hline Japão & 0,5 & 3,6 & & \\
\hline
\end{tabular}

Fonte - Emissões de GEE - Climate Analysis Indicators Tool (CAIT), World Resources Institute (WRI), Washington DC; dados populacionais - United Nations, Department of Economic and Social Affairs, Population Division, New York. Apud Satterthwaite, 2009.

Segundo o IBGE, o aquecimento global pode ser definido como a elevação da temperatura média anual do planeta Terra causada pelo aumento das concentrações na atmosfera dos chamados gases estufa, incremento este provocado, sobretudo, pelas atividades antrópicas (IBGE, 2004). 
O potencial de aquecimento global (PWA, em inglês) estima o efeito climático de cada gás de efeito estufa, a partir da forçante radiativa e do tempo de vida desse gás na atmosfera. A forçante radioativa, expressa em Watts por metro quadrado, retrata a energia absorvida e refletida por diversos componentes. É um balanço entre a quantidade de radiação que chega e a que é refletida considerando-se cada composto. Um composto capaz de refletir tem uma forçante negativa, que contribui com o resfriamento do planeta, enquanto outro que absorve tem a propriedade de esquentar, e portanto forçante positiva.

As estimativas de contribuição de cada forçante radioativa para 0 clima entre 1750 e 2005 está representada na FIG. 2.3, constante no relatório AR4. Estão representados os GEE de longa vida, o ozônio troposférico e estratosférico, o vapor d'água estratosférico, o albedo da superfície, a influência dos aerossóis e o rastro de aviões. A principal forçante negativa é representada pelos aerossóis. O total líquido devido à ação antrópica resulta em um valor positivo, de $+1,6 \mathrm{~W} / \mathrm{m}^{2}$, superior à forçante natural pelo aumento da atividade solar.

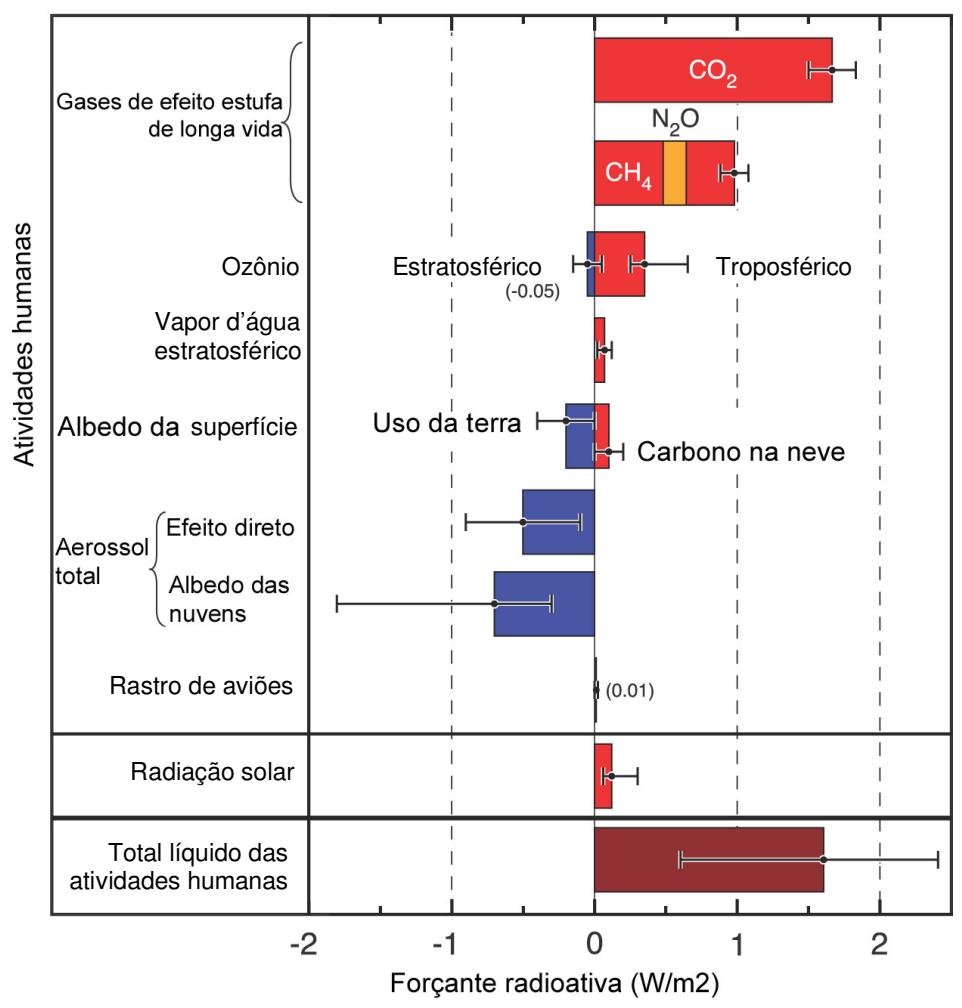

FIGURA 2.3 - Principais componentes da forçante radioativa entre 1750 e 2005 Fonte - IPCC, 2007 
As emissões parciais de cada país são geradas e contabilizadas a partir dos processos industriais que utilizam tecnologias produtoras $\mathrm{e}$ consumidoras de energia à base de carbono e do uso e mudança de uso da terra. Para calcular o aumento das concentrações dos GEE e da temperatura global, são consideradas as emissões globais e não locais ou regionais, pois os gases são diluídos por toda a atmosfera, produzindo aquecimento em todo o globo (Houghton, 1997 apud Aímola, 2006).

De acordo com o relatório AR4, entre os setores provavelmente afetados pelas mudanças estão ecossistemas terrestres, costeiros e aquáticos; o acesso à água em regiões secas e em médias latitudes e nos trópicos, com mudanças nos padrões de chuva e processos de evapotranspiração e em áreas dependentes de neve e geleiras. A agricultura em baixas latitudes e os sistemas costeiros em baixas altitudes serão impactados, em função respectivamente da redução de disponibilidade de água e do aumento do nível do mar e maior risco de extremos climáticos. A saúde de populações com baixa capacidade adaptativa está em risco. Serão especialmente afetados os que menos contribuíram com as mudanças climáticas. Pobres, crianças pequenas e os mais velhos podem estar particularmente em risco (IPCC, 2007).

Embora a adaptação ou a mitigação sozinhas não possam evitar todos os impactos das mudanças climáticas, juntas podem reduzir os riscos das mudanças climáticas. Para atingir níveis de estabilização das emissões, há necessidade de esforços e investimentos nas próximas décadas. Os investimentos em tecnologias tornaram-se primordiais.

\subsubsection{A crise climática e as negociações internacionais}

O IPCC realiza avaliações científicas sobre os estudos relacionados a mudanças climáticas e a partir dessa revisão da literatura disponível publica relatórios. O primeiro foi divulgado em 1990, seguido de uma atualização em 1992. Em 1995 foi publicado o segundo relatório e em 2001 ocorreu a publicação do terceiro relatório.

O terceiro relatório estabeleceu que existiam evidências mais fortes da influência humana no clima global, sendo muito provável (de 90 a 99\%) que o 
aumento das concentrações de GEE contribua substancialmente para o aquecimento global.

A Convenção do Clima, aprovada em 1992 na Conferência do Rio, contém recomendações para redução de emissões e o Protocolo de Quioto estabeleceu limites para emissões, contendo um cronograma para o atingimento das metas. Ambos reconhecem a responsabilidade compartilhada e diferenciada pelo aquecimento global e impõem aos países desenvolvidos maiores obrigações. Para a redução das emissões existem os mecanismos seguintes:

- MDL - permite reduzir emissões por meio de projetos de desenvolvimento sustentável em países em desenvolvimento;

- Implementação conjunta - permite execução conjunta de medidas entre países com metas de emissão obrigatórias, ou seja, um país industrializado pode compensar suas emissões financiando projetos de emissão em outros países industrializados;

- Comércio de emissões - países podem trocar suas cotas de emissões, ou seja, os que cumpriram suas metas ou não atingiram o teto de emissões podem vender para países que não alcançarem suas metas, independentemente do desenvolvimento de projetos conjuntos.

- Bolhas - países do anexo I podem cumprir suas metas conjuntamente, podendo estabelecer limite de redução conjunto, que pode ser diferenciado entre cada país.

Viola explica que desde Estocolmo-72, passando pela Rio-92 até o momento atual, a resolução dos problemas ambientais agendados sempre foi colocada num contexto de governabilidade global. Mas o papel dos diferentes atores passou por mudanças. Nos anos 1970 o papel destacado foi dos estados; na década seguinte foi da sociedade civil e nos anos 1990 o eixo da governabilidade foi deslocado para o mercado e seus atores. A governabilidade global se baseia em um sistema misto, enfatiza o autor, e não pode estar enviesado por pressupostos ideológicos ou utópicos. Para a governabilidade do ambiente global, o que realmente interessa é que determinado regime possa atender à resolução do problema ambiental ao qual está vinculado, da forma mais viável. 
"O que realmente interessa num regime ambiental é o estabelecimento de regras de ação realistas que permitam uma negociação progressiva entre os diversos atores na procura do objetivo comum. Em não poucas ocasiões, quando os regimes não funcionam, verifica-se que os atores estabeleceram regras sem nenhum compromisso com a dinâmica real do mundo contemporâneo" (Viola, 2002).

Continua o autor explicitando que só é possível efetivar um regime quando é processado realisticamente, identificando-se interesses e dando a cada ator a importância e a hierarquia devidas. Maior ou menor realização da governabilidade global depende da orientação dos atores. Os interesses nacionais não podem estar acima de qualquer outra coisa. Dessa forma, não existiria governabilidade global. A necessidade cada vez maior de cooperação internacional demanda muita flexibilidade nas negociações. Segundo Viola, o benefício coletivo exige cada vez mais ações que contrariam interesses de cada estado, de forma individual.

A atmosfera, tomada como bem público global e por sua capacidade limitada, ganhou o status de preocupação comum da humanidade, segundo Viola. Com isso, foram construídos, de forma consensual, regimes internacionais relacionados aos problemas de uso desse bem comum.

Viola lembra o papel chave da comunidade científica, ao abordar o regime internacional de mudança climática, cujos parâmetros fundamentais são a Convenção-Quadro das Nações Unidas sobre Mudança Climática, assinada no Rio de Janeiro em 1992, e o Protocolo de Quioto, assinado em 1997 na cidade japonesa:

"Quando a grande maioria de cientistas concorda no diagnóstico de um problema e é eficiente em comunicá-lo ao público em geral e aos decisores, cria-se aquilo que denominamos "comunidade epistêmica", adquirindo, então, peso internacional" (Viola, 2002).

A criação do IPCC deu início ao processo de análise e avaliação dos efeitos da mudança climática, traduzido politicamente na constituição do Comitê Negociador Internacional para uma Convenção sobre Mudança do Clima. O papel exercido pelo IPCC na formação de opinião pública internacional tem sido fundamental.

Viola afirma que os subsídios fornecidos pelo IPCC para as negociações no âmbito da convenção foram valiosos. Os EUA foram diminuindo 
seu papel de liderança, conforme avançavam as negociações. $O$ argumento sobre o alto nível de incertezas balizou a posição norte-americana, contrária ao estabelecimento de metas de redução de emissão dos GEE, enquanto Holanda e Alemanha mantinham-se favoráveis ao estabelecimento das metas obrigatórias de reduções. No texto final da Convenção, o compromisso para os países do Anexo I - desenvolvidos, da OCDE, e industrializados ex-comunistas em transição para a economia de mercado. Para países não pertencentes ao Anexo I, como o Brasil, ficou estabelecido o compromisso dos inventários nacionais de emissões de carbono (Viola, 2002).

Os países do Anexo I se comprometeram a reduzir as emissões totais de seis gases de efeito estufa, durante o primeiro período de compromisso do protocolo (2008-2012), em 5,2\% abaixo dos níveis de emissão de 1990, com metas específicas que variam de país para país (IIDS, 2010).

No histórico sobre o processo de negociação, Viola recorda o impulso favorável da opinião pública norte-americana pelo enfrentamento do problema climático. Na I Conferência das Partes da Convenção de Mudança Climática, ocorrida em Berlim, em 1995, o governo Clinton alterou a postura dos EUA e assumiu liderança defendendo as metas obrigatórias para os países desenvolvidos e metas de redução das emissões para os países em desenvolvimento. Naquele momento, o Brasil defendeu o não estabelecimento de tais metas obrigatórias para os países em desenvolvimento, na primeira fase, posição seguida por Japão e União Europeia (Viola, 2002).

$\mathrm{Na}$ II COP, em 1996, em Genebra, os norte-americanos apresentaram a ideia de cotas comercializáveis de emissão de carbono, como mecanismo complementar na redução de emissões. Também foram iniciadas as negociações para o estabelecimento de um protocolo. Nas duas COP's seguintes, em Genebra (1996) e em Quioto (1997), foram desenvolvidas as negociações que originaram o Protocolo de Quioto. Os EUA foram bem sucedidos em sua intenção de estabelecer metas de redução de emissões de menos de $5 \%$ até 2010 , tomandose como base 1990, algo modesto em relação ao que desejavam os europeus. No que diz respeito ao estabelecimento de metas de redução da taxa de crescimento das emissões por parte dos emergentes, os EUA não obtiveram êxito. Por fim, o país condicionou sua assinatura ao Protocolo à flexibilização das metas por meio de mecanismos de mercado, pelo que foram apoiados por 
Canadá, Austrália, Rússia e países do Leste Europeu. O governo Clinton não enviou o Protocolo ao Senado norte-americano para ser ratificado, enquanto tentava obter compromissos de alguns países emergentes pela atenuação no crescimento das emissões.

Nas COP's seguintes (Buenos Aires, 1998; Bonn, 1999 e Haia, 2000) houve quatro coalizões:

- União Europeia, formada por 15 países, a maioria com média intensidade de carbono por habitante e por unidade de PIB;

- Grupo Guarda-Chuva, formado por três subgrupos: países com alta intensidade de carbono por habitante e média por unidade de PIB EUA, Canadá e Austrália; média intensidade por habitante e com dificuldades em reduzir emissões - Japão, Nova Zelândia, Noruega, Suíça, Islândia; ex-comunistas que sofreram drástica redução nas emissões de carbono pelo colapso na economia - Rússia, Ucrânia, Bielo-Rússia, Bulgária, Romênia - e possuem créditos no conjunto de compromissos;

- G77/ China, formado por mais de 100 países em desenvolvimento, exceto as ilhas - todos apóiam o Protocolo, com possibilidade de ganhos pela implementação de MDL's;

- Pequenos Estados-llhas - vulneráveis às mudanças climáticas, desejam aumentar os compromissos de redução de emissões de todos os países.

Viola registra que G77/China e a Aliança de Pequenos Estados- Ilhas propuseram transferência de tecnologias limpas dos países desenvolvidos para aqueles em desenvolvimento. O grupo Guarda-Chuva e UE apoiaram pacote mais limitado. Os países exportadores de petróleo defenderam a compensação por eventuais quedas na receita de exportação. A UE propôs um regime de sanção para quem não cumprisse seus compromissos, posição contrária ao grupo Guarda-Chuva, que apresentou regime menos radical. Um alvo controverso que terminou sem solução foi o teto para a contabilidade dos sumidouros de carbono como deduções das emissões dos países do Anexo I (Viola, 2002).

O terceiro relatório oficial do IPCC foi publicado em janeiro de 2001, alertando para os riscos da mudança climática e para a necessidade de rápida 
ação. O governo Bush se retirou das negociações de Quioto em março de 2001, alegando falta de relevância depositada nos mecanismos de mercado e não estabelecimento de metas para os países de renda média com rápido crescimento de emissões. A União Europeia decidiu fazer do Protocolo de Quioto parte da sua política exterior.

"Os países passaram a considerar a aprovação final do Protocolo de Quioto como um emblema em favor de uma governabilidade do ambiente global baseada na negociação multilateral, em desacordo com a política unilateralista do governo Bush" (Viola, 2002).

A União Europeia cedeu em vários pontos do protocolo, por exemplo aceitar um regime reduzido de sanções e não colocar restrições ao uso dos mecanismos flexibilizadores, para completar e ratificar o Protocolo. O acordo ficou aquém do proposto em Haia pelo governo Clinton e que havia sido rejeitado pela União Europeia.

De acordo com Viola, as dificuldades da construção de um regime para atenuar a mudança climática se devem à maximização do interesse nacional. Diante das dificuldades da cooperação para a mitigação da mudança climática, os esforços dos países deverão orientar-se para a adaptação (Viola, 2002).

O Protocolo de Quioto entrou em vigor em 16 de fevereiro de 2005. Após a assinatura do documento ocorreram COP's: em Montreal, Canadá (COP11); em Nairóbi, Quênia (COP-12); em Bali, Indonésia (COP-13); em Poznan, Polônia (COP-14); em Copenhague, Dinamarca (COP-15). A COP-16 ocorreu em Cancún, no México, em novembro de 2010.

Na COP-11, iniciou-se o processo de discussão do segundo período de compromisso do protocolo, pós-2012. Em Bali (COP-13) houve a adoção do Plano de Ação de Bali, iniciando um processo capaz de possibilitar a implementação completa, efetiva e sustentada da Convenção, por meio de ações cooperativas de longo prazo, de modo a alcançar resultados acordados e adotar decisões em dezembro de 2009, na COP-15, em Copenhague (IIDS, 2010). Sobre a recomendação do Grupo de Trabalho III do IPCC no AR4 - de redução de emissão dos GEE de 25 a 40\% com relação aos níveis de 1990, até 2020, de forma que o aumento da temperatura média global não ultrapasse $2^{\circ} \mathrm{C}$ - a COP13 foi branda. Em uma nota de rodapé destacou a contribuição do AR4 e enfatizou a urgência do problema e necessidade de cortes profundos nas 
emissões globais. O acordo não explicita o quanto cada país vai reduzir suas emissões. É resultado de uma reunião dos EUA com Brasil, África do Sul, Índia e China e não é reconhecido por países que se sentiram excluídos nas negociações, achando que seus pontos de vista não foram levados em conta.

De Bali até Copenhague, o caminho foi longo. No ano de 2008, foram quatro sessões de negociações dos grupos de trabalho, em Bangcoc, Tailândia; em Bonn, Alemanha; em Acra, Gana; em Poznan, Polônia, respectivamente nos meses de abril, junho, agosto e dezembro. Em 2009, mais seis sessões paralelas, até a Conferência de Copenhague.

"No caminho até Copenhague, muitos sentiram que haviam sido obtidos avanços satisfatórios em questões como adaptação, tecnologia e criação de competências, mas persistiam "profundas divisões" a respeito de mitigação e certos aspectos de financiamento" (IIDS, 2010).

Como resultado final, ficou acertado a adoção de decisão onde a COP tomava nota do Acordo de Copenhague. Os países que o apoiassem poderiam expressar sua concordância. Em maio de 2010, 130 já haviam assinalado seu apoio ao Acordo. Em junho de 2010, 42 países do Anexo I e 37 países não incluídos no Anexo I informaram sobre suas metas de redução de emissões e sobre suas ações de mitigação, conforme pactuado no acordo (IIDS, 2010).

Sobre a COP-16 no México, o embaixador mexicano do clima Luis Alfonso de Alba declarou em agosto de 2010 a jornalistas que seria dada atenção particular àqueles países que sentiram que seus pontos de vista não foram levados em conta de forma significativa.

"Na COP-15, em Copenhague, foi produzido um acordo para limitar a elevação da temperatura mundial a 2 graus Celsius, que só foi fechado no apagar das luzes da conferência dinamarquesa por um punhado de nações ricas e grandes países em desenvolvimento.

No entanto, muitos países pequenos, frustrados por terem sido deixados de lado, se recusaram a assiná-lo.

De Alba citou entre os países que se sentiram excluídos na COP15 Indonésia, Malásia, Filipinas, Coreia do Sul, Paquistão, nações do Golfo, Nicarágua, Equador, Bolívia, Chile, Peru e Colômbia.

Com vistas à cúpula de Cancún, disse o diplomata, o México espera estabelecer uma parceria com países africanos, organizando encontros no continente negro" (UOL, 2010).

A reportagem "Brasil teme 'FMI ambiental' nas metas de redução", publicada na editoria de Ciência da Folha de S. Paulo em 16/08/2010, apresentou 
uma discussão a respeito do mecanismo de funcionamento da ICA, sigla em inglês para Análise e Consultoria Internacional, termo criado pelo Acordo de Copenhague. A ICA se aplicou a países em desenvolvimento; EUA, Japão e outros países desenvolvidos defendiam que tal mecanismo deveria ter poder de cobrança, como o FMI. O Brasil encarou tal postura como ingerência externa e defendeu, junto com outros países emergentes, que a ICA fosse apenas "um órgão técnico e não de regulação das políticas ambientais".

Aímola enfatiza que a percepção de cada nação a respeito do potencial de danos climáticos severos prevalece e acaba sendo determinante para as posições dos países nas negociações, muito mais do que o conhecimento científico sobre essas ameaças (Aímola, 2006).

A Comunicação Nacional é um dos principais compromissos dos países signatários da Convenção de Mudança do Clima. O Inventário Nacional de Emissões e Remoções Antrópicas de Gases de Efeito Estufa não controlados pelo Protocolo de Montreal é parte da Comunicação Nacional à Convenção Quadro da ONU sobre Mudança do Clima. A Segunda Comunicação Nacional, em processo de elaboração, tem prazo legal para submissão em 31 de março de 2011. Esta Comunicação segue diretrizes metodológicas do IPCC e a responsabilidade por sua elaboração é do $\mathrm{MCT}$, ministério responsável pela coordenação da implementação da Convenção de Mudança do Clima no Brasil, conforme divisão de trabalho no governo que foi estabelecida em 1992 (Brasil, 2009).

\subsubsection{Adaptação e mitigação}

As mudanças climáticas afetarão mais fortemente os países que menos contribuíram para o problema e que são também os menos preparados para lidar com a nova situação (IPCC, 2007). Serão necessárias medidas de adaptação e mitigação, que podem reduzir os riscos. Embora a adoção de medidas pelos governos nacionais seja fundamental, há muitas questões a serem consideradas. O custo de tais medidas e a melhor forma de encaminhar as decisões envolvem muitas variáveis, incluindo decisões que podem envolver governos em vários níveis. Especialmente conhecer os impactos das mudanças climáticas de determinada região. Muitas das nações a serem impactadas são 
aquelas com menos condições de arcar com programas ou projetos de maior porte para combater as alterações climáticas.

Walker e King (2008) mencionam que na adaptação às mudanças climáticas parte da resposta envolve projetos de engenharia, por meio de sistemas de alarme e preparo. E mudanças em vários aspectos da vida serão necessárias, o que pode ser particularmente difícil.

É preciso investimento para os projetos de adaptação. Em algumas partes do mundo começam a ser incorporados sistemas para atenuar os efeitos das mudanças climáticas.

Mas no imaginário sobre o tema, ainda domina o cenário de desastre quando o assunto são as mudanças climáticas. As tecnologias de captura e armazenamento de carbono, por exemplo, não recebem ampla projeção na mídia. Um exemplo sobre o desconhecimento desse tema é citado pelo IPCC em um de seus relatórios especiais sobre captura e armazenamento de dióxido de carbono, em que afirma ser pequeno número de estudos de percepção pública sobre armazenamento de $\mathrm{CO}_{2}$ no oceano, indicando que há pouca preocupação ou conhecimento sobre o tema (IPCC, 2005). Deve-se ressaltar que há diferentes estágios de engajamento, participação e conhecimento sobre o tema, dependendo de qual país é levado em consideração.

A Convenção-Quadro das Nações Unidas sobre Mudanças do Clima adotou alguns princípios, entre eles o de precaução, que significa antecipar soluções diante de algo que se sabe que irá ocorrer ou poderá ocorrer, segundo alguma estimativa (Barbieri, 2007). Precaução significa antecipar a cautela diante da incerteza, de algo que não se conhece ou cujo conhecimento é insuficiente para estabelecer medidas de prevenção.

O PNUD, em seu Relatório de Desenvolvimento Humano 2007/2008, propõe cortar as emissões em pelo menos $80 \%$ até 2050; investir anualmente um adicional de pelo menos U\$ 86 bilhões em esforços de adaptação, a fim de proteger os mais pobres do mundo, apoiando a produção de biocombustíveis sem prejudicar os direitos dos pequenos agricultores ou populações indígenas; e apoiando os esforços para reduzir o desmatamento de florestas em países como o Brasil. O relatório argumenta que, com o apoio de tais medidas e através de uma cooperação financeira internacional e tecnologia de baixo carbono, países 
em desenvolvimento também deveriam participar, cortando suas emissões em 20\% até 2050 (PNUD, 2008).

Já que a atividade que mais consome petróleo é o transporte individual, assim como a fonte de emissões de $\mathrm{CO}_{2}$ é a que cresce mais rápido, tanto os países desenvolvidos como os países em desenvolvimento deveriam utilizar diferentes combustíveis no setor de transporte, aponta o relatório. Destaca ainda que o Brasil possui um dos exemplos mais bem sucedidos mundialmente, com um terço de seu setor de transporte rodando com etanol de cana-de-açúcar, "o mais limpo e barato biocombustível desenvolvido nas últimas décadas". A redução do desmatamento é apontada como prioridade para assegurar que as emissões de $\mathrm{CO}_{2}$ possam ser suficientemente mitigadas. Entre os anos 2000 e 2005 houve uma perda anual média de $73 \mathrm{mil} \mathrm{km}^{2}$ de florestas em todo o planeta - área equivalente à superfície do Chile. Cada hectare perdido amplia as emissões de gases que provocam o efeito estufa. O relatório recomenda transferências financeiras de países desenvolvidos para os países em desenvolvimento que reduzirem voluntariamente suas emissões de GEE, preservando suas florestas.

O Banco Mundial destaca as ambiciosas metas brasileiras relacionadas ao plano nacional de ações sobre mudanças climáticas. Entre elas, a redução do desmatamento em 80\% em 2020; expansão da capacidade instalada de energias renováveis em 7.000 MW em 2010; aumento de energia renovável proveniente de bagaço de cana para $11 \%$ do total da geração elétrica; aumento do uso de etanol como combustível para $11 \%$ por ano; diminuição do uso de energia devido à melhoria de 10\% em eficiência energética em 2030 (WB, 2010).

A divulgação do quinto relatório do IPCC (AR5) já tem data marcada e a seleção de autores movimenta a comunidade científica mundial. Em setembro de 2013 será divulgado o capítulo do grupo de trabalho I, que cuida das bases das ciências físicas; em março de 2014, o relatório do grupo de trabalho II, sobre impactos, adaptação e vulnerabilidade e em abril de 2014 o relatório do grupo III, referente às possibilidades de mitigação. Em setembro de 2014 será apresentado o relatório-síntese, reunindo as conclusões de todos os grupos de trabalho. 


\subsubsection{Incertezas associadas}

A Convenção-Quadro das Nações Unidas sobre Mudanças do Clima ${ }^{4}$, assinada em 1992 e em vigor internacional desde 1994, preconiza em seu artigo 3 (Princípios), item 3, que a falta de plena certeza científica não deve ser usada como razão para postergar medidas para prever, evitar ou minimizar as causas da mudança do clima e mitigar seus efeitos negativos, quando surgirem ameaças de danos sérios ou irreversíveis. Também destaca que as políticas e medidas adotadas para enfrentar a mudança do clima devem ser eficazes em função dos custos, de modo a assegurar benefícios mundiais ao menor custo possível. Tais políticas e medidas devem levar em conta os diferentes contextos socioeconômicos, ser abrangentes, cobrir fontes, sumidouros e reservatórios significativos de gases de efeito estufa e abranger os setores econômicos.

Aímola (2006) destaca que, diante das incertezas, a possibilidade de interferência perigosa no clima - que levou à assinatura da Convenção do Clima e à instauração de um Regime Internacional de Mudanças Climáticas - torna-se difusa.

Mols aponta as três fontes de incertezas na ciência: em medições, em análises de dados e em modelos. Os cientistas tentam minimizá-las ao máximo, mas é impossível suprimi-las. Na percepção do público, ao contrário, a ciência é uma enciclopédia de fatos absolutamente verdadeiros, observa (Mols, 2010).

Continua Mols afirmando que quando o público ouve cientistas dizendo que eles não sabem sobre tudo a respeito de determinada questão, concluem ou tendem a concluir que os cientistas não sabem nada ou que uma opinião é tão boa quanto qualquer outra ou, no caso específico do IPCC, que erros evidentes em um relatório invalidam todo o restante. Incerteza em ciência, contudo, é algo diferente da má ciência. Há níveis de incerteza, variando de extremamente incerto a virtualmente certo. Dificilmente algo em ciência é absolutamente certo (Mols, 2010).

Merece reflexão a observação de Richard Feynman, físico ganhador do prêmio Nobel, a respeito das certezas na ciência:

"É muito mais interessante viver sem saber do que ter respostas que devem estar erradas. Não me sinto assustado em não saber as coisas" (Feynman apud Mols, 2010).

\footnotetext{
${ }^{4}$ United Nations Framework Convention on Climate Change (UNFCCC), disponível em www.unep.org
} 
Quando se fala no aumento da certeza do último relatório de avaliação do IPCC, é importante frisar que a confiabilidade de mais de $90 \%$ refere-se ao fato de as mudanças climáticas serem creditadas à ação antropogênica. Isso não quer dizer que as projeções de futuro, por exemplo, de aumento de temperatura têm essa confiança.

A atribuição com alto grau de certeza de que as mudanças se devem à ação humana pode ser explicada pelo conhecimento decorrente de observações experimentais dos últimos anos. São estudos mais extensos e melhor realizados. Por exemplo, aumentaram as informações sobre a Amazônia, importante ecossistema para o mundo, vide o projeto LBA, de grande escala, que permitiu desenvolver pesquisas climáticas e ambientais na região. No entanto, especialistas reconhecem que ainda há muito a ser feito para compreender melhor este e outros ecossistemas e suas contribuições para o balanço atmosférico global.

Como explica Aímola, em alguns casos as incertezas resultam da ausência de informações ou de conhecimento que, em princípio, poderiam ser superadas com pesquisa adicional. Em outros casos, resultam da variabilidade natural inerente aos processos climáticos, "o que torna a previsibilidade destes processos extremamente grosseira, como ocorre com as flutuações das condições de tempo atmosférico". Em outras situações ainda, "como no caso das inovações tecnológicas, as incertezas vêm de processos que são essencialmente imprevisíveis" (Aímola, 2006).

\footnotetext{
"Os níveis de incerteza nos estudos de mudanças climáticas podem variar desde incertezas estatísticas, quando os pesquisadores podem atribuir probabilidades a diferentes possibilidades, passando por incertezas de cenários, quando os pesquisadores podem caracterizar uma variedade de resultados plausíveis, mas não podem entender os processos subjacentes o suficiente para atribuírem probabilidades, indo até a ignorância quando os pesquisadores não têm suficiente conhecimento nem mesmo para desenvolverem cenários plausíveis"(Aímola, 2006).
}

Aímola discorre sobre como deveriam as incertezas diminuir a fim de que o sistema de decisão coletiva baseado em negociações sobre abatimento de emissões evitasse os impactos climáticos perigosos. Destaca que o sistema do clima tem dinâmica própria e que pode surpreender tanto cientistas quanto políticos. O sistema de relações envolve elementos e processos naturais e elementos e processos humanos. Aponta estratégias utilizadas para tratar das 
incertezas nos estudos sobre mudanças climáticas. Nos modelos de análise integrada, explica, são considerados os vários aspectos do problema: físico, econômico e social, em um quadro conceitual. Os dois principais desafios no trabalho com tais modelos seriam, conforme apontado pelo IPCC (Houghton et al., 1995 apud Aímola, 2006):

- Integrar e manipular um grande e diverso conjunto de dados e modelos a partir de muitos pesquisadores e um conjunto amplo de disciplinas;

- Aprimorar nesses modelos o tratamento de questões de relevância para políticas, tanto quanto aprimorar a apresentação dos resultados para os políticos.

Aímola argumenta que não existem teorias ou modelos sobre como o conhecimento científico pode evoluir. Relembrando Karl Popper, afirma que se fosse possível prever a evolução de uma teoria científica, então já se conheceria tudo o que ela pretende explicar e então esta não seria necessária (Popper, 1980 apud Aímola, 2006). Não existindo estudos sistemáticos sobre como as incertezas em uma área específica irão evoluir, os programas de pesquisa tentam atacar as questões ainda sem respostas. Com mais investimentos em pesquisas em determinadas áreas, a tendência é avançar no conhecimento.

Mesmo não sendo possível prever a evolução do conhecimento, continua Aímola, é possível imaginar cenários de evolução desse conhecimento.

"Se um modelo de mudança do clima apresenta incertezas epistêmicas e paramétricas, contendo parâmetros cujas incertezas sobre os seus verdadeiros valores podem ser representados por distribuição de probabilidades subjetivas, então poderemos imaginar várias evoluções destas incertezas através de transformações temporais da forma das distribuições. As probabilidades subjetivas baseiam-se em grandes conjuntos de informações de várias áreas e em opiniões de muitos especialistas e por isso estarão sujeitas a revisões contínuas. Novas evidências observacionais, conjugadas ao aprimoramento de técnicas de modelagem levarão inevitavelmente a revisão de posição por parte desses especialistas e novas distribuições de probabilidades passarão a representar as incertezas sobre os valores dos parâmetros dos modelos" (Aímola, 2006).

Aímola cita ainda dois tipos básicos de evolução das incertezas: a evolução gradual e a evolução abrupta. No primeiro caso, a distribuição de 
probabilidades muda de forma gradual de ano a ano, a uma taxa constante, implicando em alteração significativa após muitos anos e, no segundo caso, podem ocorrer várias situações: inicialmente gradual com um salto para a certeza total, ou inicialmente gradual e com saltos pequenos seguidos de fases de estagnação ou avanço gradual, entre outras situações.

\subsubsection{Controvérsias}

Alguns cientistas apresentam argumentos contra a conclusão principal do IPCC de que o aumento na concentração dos gases de efeito estufa levou ao aumento da temperatura média. Esta conclusão resultou especialmente das simulações realizadas pelos modelos computacionais. Os que discordam desses resultados argumentam que o clima envolve muitas variáveis e os modelos são limitados, ou seja, incapazes de abranger a totalidade de tais variáveis. Também argumentam que há causas naturais que provocam mudanças do clima, como os movimentos da Terra e as atividades solares, para contestar a componente antropogênica como responsável pelo aquecimento global. Outras críticas estão relacionadas ao investimento no combate às mudanças climáticas, quando há outros problemas de maior urgência para se resolver.

O cientista canadense e cético sobre a influência humana no aquecimento global Tim Patterson afirmou à revista Veja, na edição 2006, de 02/04/2007 ${ }^{5}$, que todo o dinheiro desperdiçado com Quioto poderia ser usado para fornecer água potável à África. O professor de ciência ambiental Chris de Freitas, da Universidade de Auckland, na Nova Zelândia, afirmou à revista Veja, edição 2031 de 24/10/2007 ${ }^{6}$, que ser cético não significava ser contrário ao ambiente. Seria "zelar pelo ambientalismo de forma coerente".

No Brasil, o pesquisador Luiz Carlos Baldicero Molion, da Universidade Federal de Alagoas, defende que a variabilidade natural do clima não permite afirmar que o aquecimento seja decorrente da intensificação do efeito estufa causada por atividades humanas, ou mesmo que a tendência de aquecimento persistirá nas próximas décadas. Segundo ele, a redução do albedo planetário e a atividade solar mais intensa entre 1925 e 1946 provocaram o aumento da temperatura dos oceanos. Com isso, a absorção de $\mathrm{CO}_{2}$ pelos oceanos pode ter

\footnotetext{
5 http://veja.abril.com.br/020507/vejaessa.shtml
}

${ }^{6} \mathrm{http}: / /$ veja.abril.com.br/241007/p_086.shtml 
sido reduzida e mais $\mathrm{CO}_{2}$ ter ficado armazenado na atmosfera. Assim, teria ocorrido um aumento desse gás como resposta ao aumento de temperatura dos oceanos e do ar subjacente. Também destaca que o clima do planeta resulta de tudo o que ocorre no Universo. Outros argumentos e estudos são utilizados pelo pesquisador para contestar afirmações sobre o aquecimento da Terra.

O bom senso, defende Molion, sugere adotar "políticas de conservação ambiental bem elaboradas e mudanças nos hábitos de consumo para que as gerações futuras possam usufruir dos recursos naturais disponíveis atualmente". A conservação ambiental é necessária e independe de mudanças climáticas, de acordo com ele (Molion, 2008).

Em 2007, quando o IPCC divulgou seu relatório de maior alcance mundial, um dos cientistas do chamado grupo cético, Bjorn Lomborg, da Copenhagen Business School, afirmou, também à revista Veja, edição 2031, de 24/10/20077: "Num planeta onde 15 milhões de pessoas morrem todo ano por causa de doenças infecciosas que poderiam ser evitadas, e no qual só se fala em efeito estufa, me parece que estamos invertendo nossas prioridades". Lomborg defendia que o custo de combate ao aquecimento era elevado demais para o benefício de se ter um mundo ligeiramente menos quente no futuro e seguia essa linha de pensamento em suas palestras e entrevistas.

Em 2010, Lomborg, que chegou a ser chamado de 'Hitler do Clima', afirmou ao jornal inglês The Guardian, na edição 30/08/2010 ${ }^{8}$, que irá lutar contra a mudança climática. Após rever métodos para combater a mudança climática em conjunto com um grupo de economistas, ele sugere que haja investimentos em energias limpas como eólica, marés, solar e nuclear. O cientista defende investimentos de US $\$ 100$ bilhões por ano em métodos de redução do aquecimento global. Uma reviravolta em seu posicionamento frente à ameaça climática.

Em novembro de 2009, a postura de cientistas participantes do IPCC foi questionada após o vazamento de e-mails trocados entre pesquisadores do centro de pesquisas climáticas da Universidade de East Anglia, na Inglaterra. Os e-mails mostravam relutância dos pesquisadores em compartilhar dados climáticos e sugeria a exclusão de papers que contrariavam conclusões de

\footnotetext{
${ }^{7}$ http://veja.abril.com.br/241007/p_086.shtml

${ }^{8} \mathrm{http}: / /$ www.guardian.co.uk/environment/2010/aug/30/bjorn-lomborg-climate-change-u-turn
} 
trabalhos utilizados no AR4. Tal postura foi atacada e utilizada como argumento para críticas às conclusões do IPCC, especialmente pelos céticos do clima. Chamado de Climagate, discutiu-se o episódio, que foi investigado e inocentou os cientistas envolvidos no que diz respeito à desonestidade nos dados.

Divulgado às vésperas da COP-15, não se pôde precisar qual foi o impacto de tais revelações nos resultados de Copenhague. Para Ben Stewart, diretor de mídia do Greenpeace em entrevista ao jornal britânico The Guardian", não se pode dizer que não houve influência do episódio nos resultados da conferência. O caminho teria ficado mais longo e o fardo mais pesado. Segundo ele, a mídia criou uma simetria entre os diferentes lados do debate, contribuindo para confundir o público.

De acordo com Michael Jacobs, conselheiro do primeiro ministro britânico Gordon Brown e pesquisador adjunto na London School of Economics, na mesma reportagem, o episódio teve menos impacto do que algumas pessoas esperavam. Poderiam ter sido feitos mais questionamentos por qualquer governo durante a COP-15, mas isso não aconteceu. Houve tentativas de usar o episódio para sustentar posições contrárias a acordos globais para conter emissões, por parte da Arábia Saudita. Para ele, a descrença climática aumentou.

Bob Ward, diretor de comunicação do Instituto de Pesquisas Grantham sobre Mudanças Climáticas e Meio Ambiente, afirmou ao jornal britânico, na mesma reportagem, que o episódio "não afetou o processo político de forma direta", pois os governos têm conselheiros científicos que sabem que se trata de "tempestade em copo de água". Sobre o impacto na opinião pública, afirmou não ter percebido nenhuma evidência de que houve alguma grande mudança. Embora destaque que pode haver um efeito indireto, de um público confuso que sinta menor necessidade de pressionar em prol de políticas para cortar emissões.

Ao revisar os processos e procedimentos do IPCC, o IAC, organização científica mundial, recomendou ${ }^{10}$ que o painel do clima deveria ser tão transparente quanto possível na forma como trabalha, como seleciona pessoas para participar de seus relatórios e suas escolhas por informações científicas.

\footnotetext{
${ }^{9}$ http://www.guardian.co.uk/environment/cif-green/2010/jul/08/hacked-climate-science-emails-climatechange

${ }^{10} \mathrm{http}: / /$ reviewipcc.interacademycouncil.net/ReportNewsRelease.html
} 
Para o próximo relatório do IPCC (AR5), o presidente do IPCC Rajendra Pauchauri ${ }^{11}$ afirmou em carta aos 831 cientistas participantes que 0 trabalho impõe uma grande responsabilidade e é preciso certificar que erros de qualquer tipo sejam completamente eliminados do AR5. Conclamou os participantes a trabalhar com um nível de rigor talvez não antes visto nos relatórios anteriores. Já foram feitas correções de afirmações do relatório anterior, como por exemplo erros de revisão e cálculo sobre o derretimento das geleiras do Himalaia em 2035. Outros erros em cálculos e números foram detectados no mesmo capítulo e informados por cientistas participantes do próprio IPCC.

De acordo com o jornal The Guardian, Pauchauri também aconselhou que os pesquisadores mantenham distância da mídia e que perguntas sobre o grupo de trabalho dos pesquisadores sejam direcionados aos que presidem cada grupo. Questões gerais sobre o IPCC devem ser encaminhadas ao secretariado do órgão, de acordo com orientação do dirigente. Interpretações das afirmações feitas por Pauchauri dão conta que os pesquisadores são livres para falar com jornalistas sobre seu próprio trabalho, mas que deveriam evitar falar sobre 0 procedimento do IPCC, que é bastante complexo. Para Ben Kirtman, da área de modelagens climáticas, na Universidade de Miami, EUA, e fonte também ouvida na reportagem do jornal britânico, Pauchauri deveria simplesmente ter lembrado aos pesquisadores que eles não representam formalmente o IPCC.

\subsection{Segurança energética e mudanças climáticas}

De acordo com o Conselho Mundial de Energia (WEC), o mundo precisa desenvolver uma abordagem prática e coerente para reduzir as emissões de GEE. Profissionais da área de energia têm buscado identificar políticas que implementadas possibilitem promover o desenvolvimento sustentável (WEC, 2007).

Uma forma eficiente de descarbonizar a economia é investir em energias renováveis. Em 1990, nos países da OECD, as fontes renováveis correspondiam a $5,8 \%$ da total de energia primária e $12,7 \%$ no total mundial. Em 2008, esse total passou a 6,9\% e 12,8\% respectivamente. Em 2009, dados

\footnotetext{
${ }^{11} \mathrm{http} / /$ www.guardian.co.uk/environment/2010/jul/19/ipcc-scientists-media
} 
estimados mostram que as fontes renováveis somam 7,3\% nos países OECD, 0 que representa uma taxa de crescimento anual de 1,2\% entre 1990 e 2009.

Neste contexto, se insere o desafio de adoção de políticas energéticas que contribuam para combater as mudanças climáticas. Com a avalanche de mudanças vivenciadas nos últimos anos, a questão climática passou a ser assunto primordial na agenda global. Trata-se de um desafio considerável manter o suprimento energético sem, no entanto, agravar a crise climática.

Outra questão importante seriam as políticas públicas, que não teriam se mostrado adequadas à dimensão do problema. A crise econômica vivenciada nos últimos anos - que se expandiu de forma rápida e em escala global - teria desencorajado os esforços de combate às mudanças climáticas, de acordo com o WEC (WEC, 2009). Aponta o organismo internacional que o impacto da crise pôde ser sentido de modo considerável no setor de energia:

- Houve diminuição da demanda energética global.

- Os preços sofreram impacto devido à volatilidade dos custos dos combustíveis e das commodities.

- A capacidade de investimento foi afetada, especialmente aquela dos pequenos e médios investidores.

De acordo com as análises do WEC, a intensidade de carbono por unidade de energia utilizada é o fator principal para as diferenças entre os níveis de emissões dos países. A intensidade de carbono emitido depende obviamente dos recursos de cada país e das fontes energéticas adotadas. Dois setores importantes cujos níveis de emissão crescem de forma significativa são transportes e eletricidade (WEC, 2009). Este último, que responde por cerca de 2/3 do total de emissões, possui o maior potencial para diminuir emissões e sua intensidade de carbono, devido à disponibilidade de tecnologias mais limpas. A adoção das fontes renováveis e investimentos em eficiência energética são objetivos tanto para os países desenvolvidos como os países em desenvolvimento.

Vale ressaltar que o a matriz energética brasileira, de acordo com relatório de 2009 do WEC, em sua oferta de energia primária, é composta por:

- $43 \%$ petróleo

- $27 \%$ outras fontes renováveis 
- $14 \%$ hidroelétricas

- $8 \%$ gás

- $7 \%$ carvão

- $1 \%$ nuclear

Ainda segundo o WEC, a conservação de energia responde por $20 \%$ aproximadamente do aumento de eficiência no uso de energia por parte dos consumidores. As políticas de eficiência energética têm sido adotadas junto com instrumentos de mercado e se constituem em desafio para todos os países. Outra questão que merece ser destacada é que a intensidade energética também é influenciada por mudanças na estrutura econômica, já que os serviços requerem sete vezes menos energia por unidade de valor agregado do que a indústria (WEC, 2004).

Nas indústrias intensivas em energia, a redução de consumo de energia por tonelada de produto tem se mostrado uma tendência geral, nos países mais desenvolvidos, enquanto que nos demais a situação é variável, pelas diferenças nos processos de produção e nos próprios produtos (WEC, 2004). A mesma análise do órgão mundial de energia aponta que a América do Norte e a Oceania estão entre as poucas regiões do mundo que, desde 1973, vêm obtendo grandes melhorias no nível de eficiência geral dos transportes. Na América do Norte, isso se deve ao melhor funcionamento dos automóveis, seguida pela implantação de padrões referentes à economia de combustível nos carros novos. $\mathrm{Na}$ Europa Ocidental, poucos programas de eficiência energética foram implantados e, em termos gerais, a eficiência do setor de transportes não sofreu qualquer avanço a partir de 1990. O consumo de energia nos transportes tem aumentado mais lentamente do que o PIB, devido à melhoria da eficiência energética, combinado com o contínuo aumento no preço dos combustíveis e medidas de eficiência energética em transporte urbano. Também ocorre a saturação do mercado de venda de automóveis. Em alguns países, pode ser observado declínio no consumo de energia em transportes.

$\mathrm{Na}$ América Latina, África e Sudoeste Asiático, o consumo de energia nos transportes aumentou mais rapidamente do que a atividade econômica, devido ao maior número de veículos automotivos em circulação e porque o transporte de mercadorias antes realizado por meio de ferrovias e hidrovias 
passou a ser feito por rodovias. Baixas condições econômicas que prevalecem na América Latina reverteram essa tendência nos últimos anos. Na China e no Sul da Ásia, o consumo de energia nos transportes tem aumentando menos devido ao crescimento lento da frota de automóveis e ao papel ainda predominante das ferrovias para transporte de mercadorias (WEC, 2004).

O aquecimento global e o esgotamento das reservas de petróleo e gás entre 2030 e 2050 servem de motivação para as políticas de eficiência energética. Nos países não pertencentes à OCDE, a eficiência energética serve de alívio às restrições de investimento do lado do fornecimento. A partir de 2000, com 0 aumento dos preços do petróleo, muitos países, especialmente os menos desenvolvidos, enfrentam restrições de ordem macroeconômica. $\mathrm{Na}$ análise do WEC (2004), as autorizações para o intercâmbio de emissões de $\mathrm{CO}_{2}$ podem permitir que os países do Anexo I evitem, no curto prazo, grandes restrições para suas indústrias, mas, no longo prazo, os preços devem aumentar, tornando a energia cada vez mais cara.

Continua o WEC (2004) observando que as decisões sobre investimentos em infraestrutura devem incorporar a possibilidade de aumentar 0 preço da energia e de restringir as emissões de $\mathrm{CO}_{2}$. A diminuição das emissões de $\mathrm{CO}_{2}$ no setor dos transportes poderia ser feita incluindo-se o valor do carbono nas decisões públicas, de forma que a escolha dos consumidores possa recair sobre soluções energéticas eficientes.

Além da eficiência energética, o incentivo ao uso de energia renovável e à energia nuclear está em pauta. O WEC aponta, em seu relatório de 2010, que mais de 30 países estão investindo em programas nucleares. Em todo o mundo, 52 reatores estão em construção, 140 autorizados ou planejados e 344 em estágio de proposição. A atual capacidade mundial de cerca de $367 \mathrm{GW}$ deve ampliar entre $600 \mathrm{GW}$ e $1.340 \mathrm{GW}$ no ano de 2030. Esse desenvolvimento deve ocorrer em países que já dispõem de infraestrutura na área nuclear que também estão tentando diminuir a participação do carvão em sua matriz energética. Países como EUA, Itália, Finlândia e Suécia decidiram expandir sua capacidade nuclear. Também cita como exemplos de países que planejam crescimento para seu setor nuclear Brasil, Rússia, Índia, China, África do Sul, Japão, Ucrânia, República Tcheca e EUA. O potencial nuclear está sendo considerado para satisfazer o crescimento da demanda energética em países como a Indonésia, 
Irã, Casaquistão, Vietnam, Países do Golfo Pérsico, Nigéria, Polônia e Itália. Em 2009, a China ampliou em 75\% o investimento em infraestrutura na área nuclear em relação ao ano de 2008. E a capacidade nuclear instalada do país deve aumentar de $2 \%$ para $5 \%$. Países com capacidade nuclear instalada estão aumentando a vida útil da infraestrutura existente; aumentando a capacidade dessa infraestrutura e construindo novas instalações.

Companhias originárias de países com expertise na área estão oferecendo suporte para países iniciantes, que também estão sendo auxiliados pela AIEA. Para muitos países, carvão e petróleo permanecem como recursos essenciais, mas fontes renováveis, nuclear e gás têm potencial para alterar a composição da matrix energética e a dependência de energia em muitos países. Um mix diversificado proporciona segurança no suprimento e se constitui em uma opção interessante do ponto de vista ambiental, explicita o organismo mundial (WEC, 2010).

Para incrementar a matriz energética em renováveis, países e cidades em todo o mundo vêm investindo em leis específicas ou políticas de cotas, de forma que a participação vá aumentando gradativamente. O mercado de renováveis é promissor e tem alcançado recordes de investimento.

$\mathrm{Na}$ FIG. 2.4 estão demonstrados os países que lideram os investimentos em energia limpa em 2009 e que apresentam maior crescimento em termos percentuais nesses investimentos nos últimos cinco anos (2004-2009). Os dados são de Bloomberg New Energy Finance/Pew, de 2010.

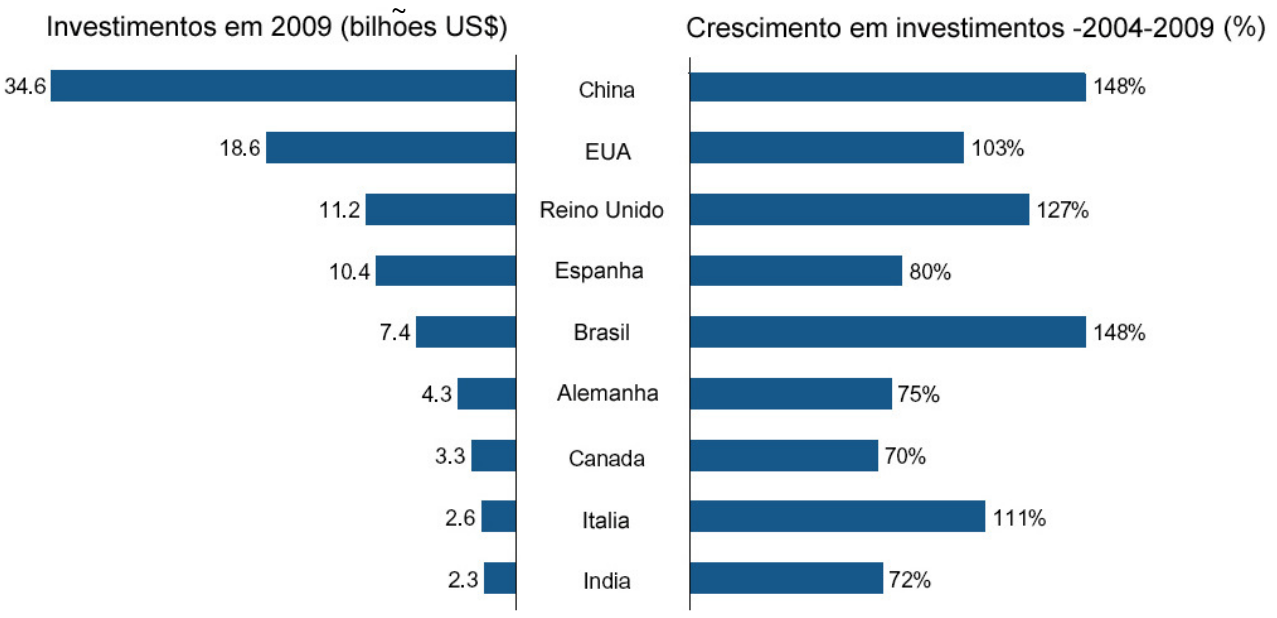

FIGURA 2.4 - Países que mais investiram em energia limpa em 2009 (bilhões de dólares) e expansão de investimentos nesse segmento de 2004 a 2009

Fonte -Bloomberg New Energy Finance/Pew, 2010 (Apud WEC, 2010). 


\subsection{Energia nuclear e mudanças climáticas}

Mil novecentos e quarenta e cinco marcou a explosão da primeira bomba atômica. Após dois meses desta explosão, civis de Hiroshima e Nagasaki viveram o mesmo drama. O medo das armas nucleares pautou os anos $1970 \mathrm{e}$ inspirou filmes hollywoodianos. Os ecologistas se lançaram à defesa do planeta contra a ameaça nuclear. Com a crise do petróleo em 1973, o mundo desperta para outra ameaça: o fim dos combustíveis fósseis. A energia nuclear desponta como alternativa.

Especialmente na França, em 1974, o primeiro ministro Pierre Messmer incrementa os investimentos na área nuclear. O Plano Messmer, como ficou conhecido, aproximou governo e indústria. Electricité de France, distribuidora de energia, e Areva, empresa do ramo nuclear, dão suporte às medidas governamentais que resultaram no sucesso do projeto nuclear francês. A Areva tornou-se uma indústria competitiva e imponente e a política energética, um exemplo de sucesso (WEC, 2009).

Morais registra que o mundo começou a assistir a uma sequência de catástrofes a partir da década de 1980: Seveso, Bhopal, Three Miles Island, Chernobyl. A desertificação do Mar de Aral, a poluição do lago Baikal, a poluição do ar em níveis alarmantes em megalópolis como a Cidade do México e Atenas. Desastres regionais como a poluição do rio Reno, atingindo Suíça, França, Alemanha, Países Baixos e até o mar do Norte. Todos esses eventos despertaram para o perigo global que ameaçava o planeta. $E$ alimentaram os movimentos em prol do ambiente.

Pesquisas indicam que uma expansão de 10 vezes mais usinas nucleares em operação diminuiriam as emissões de $\mathrm{CO}_{2}$ em $15 \%$ em um período de 75 anos (van der Zwaan, 2002 apud McCormick, 2007). McCormick observa que não há uma solução tecnológica única para a mudança climática, o que é compartilhado por vários pesquisadores. O caminho a ser adotado deveria ser 0 desenvolvimento de estratégias de mitigação diversificadas que promovam o uso das melhores tecnologias energéticas de baixa emissão em conjunto a outras medidas como conservação de energia, eficiência energética e programas de gerenciamento da demanda. A expansão da energia nuclear ajudaria a controlar os níveis de emissões, permitindo um ganho de tempo para a transição em 
direção às fontes energéticas alternativas de baixa emissão ou emissão zero de carbono. Sem a expansão nuclear, aumentam as probabilidades de se ultrapassar os níveis estipulados como metas (Knapp, 1999 apud McCormick, 2007).

\subsection{A mediação dos meios de comunicação}

De acordo com o relatório Science and the Media, produzido no Reino Unido, o posicionamento dos indivíduos e sociedade frente a varias questões é diretamente influenciado pela mídia, que ao mesmo tempo pode contribuir para tornar a ciência melhor.

"A ciência está no centro de quase todos os desafios que enfrentamos - como combater as mudanças climáticas, como produzir alimentos para a crescente população, como tratar doenças incuráveis que custam tantas vidas. A compreensão pública e atitude em prol da ciência continuam a ser fortemente influenciadas pela mídia" (BIS, 2010).

No documento, também é mencionada a homogeneização da ciência, ou seja a cobertura pasteurizada, pelos vários veículos, uma realidade de certa forma imposta porque os competidores certamente vão noticiar ou reportar aquele tema. Este seria um fator desencorajador do jornalismo original.

Ao mesmo tempo, a crise no jornalismo tradicional, diminuição de anunciantes, transformação do modelo de negócios das empresas que produzem jornais está impondo novos desafios. Seria possível novos modelos de jornalismo? E quanto à independência na produção dos conteúdos? Quais as melhores estratégias para novos modelos de jornalismo, especialmente no âmbito da ciência? Algumas questões intrigantes somam-se à realidade das novas tecnologias transformando o modo de se produzir as notícias, incluindo-se aí as redes sociais e todas as formatações e possibilidades advindas com a internet.

Há diversas recomendações no relatório, passando pelo treinamento de jornalistas a abertura e transparência por parte das instituições. A situação atual seria de cada vez mais cientistas interagindo com a mídia, a partir de uma nova cultura construída, que se distancia do tempo em que os cientistas permaneciam isolados nos seus laboratórios.

São imensos os benefícios de se ampliar a confiança do público e a compreensão do modo de se fazer ciência. E mais: tornou-se fundamental que o 
conhecimento gerado nas instituições esteja disponível ao público e àqueles responsáveis por informar o debate público (BIS, 2010).

Duarte explica que o desenvolvimento cada vez mais célebre dos meios de comunicação, com as novas tecnologias e a revolução digital, influencia na remodelação da esfera política, de várias formas: "transformando os padrões do discurso, as relações entre representantes e representados, o acesso do cidadão aos vários nichos de poder, a desmistificação dos líderes políticos, as mudanças dos conceitos de tempo e espaço, de organização da vida social e, principalmente, na percepção do mundo e de uma nova realidade midiática" (Duarte, 2007).

Continua Duarte enfatizando que participação tornou-se, então, componente indispensável do processo de construção da cidadania na sociedade atual, caracterizada como do conhecimento, sendo o uso desse conhecimento um dos grandes diferenciais competitivos entre as nações. A mídia tem papel central na vida das sociedades e a relação entre informação, conhecimento e cidadania tornou-se estreita. As novas tecnologias e instrumentos de comunicação seriam essenciais na nova realidade, permitindo a inserção social de comunidades e com isso permitindo o resgate da cidadania (Duarte, 2007).

Vale ressaltar que o jornalismo é, na prática, uma forma de se realizar a luta pelo poder, conforme pontua Marcondes Filho, para quem "a imprensa instrumentaliza as informações que colhe, recebe ou mesmo fabrica-as, transformando-as em notícias para usá-las no jogo político-ideológico, em uma palavra, no jogo do poder" (Marcondes, 1993 apud Faria, 2007).

$\mathrm{Na}$ seleção e construção das informações jornalísticas, Chaparro relaciona uma série de interesses: os dos entrevistados, legítimos, que também devem ser conhecidos e levados em conta; o do leitor; o do anunciante, que garante o lucro do empreendimento jornalístico, e o interesse maior do empresário dono do meio (Chaparro, 1996 apud Faria, 2007).

Faria destaca que a imprensa tradicional tem sido a vitrine de exibição dos temas da agenda pública. Estado e atores privados enviam sua mensagem para que a imprensa possa não somente difundir a informação, mas assumi-la sob a ótica do interesse público. E uma nova realidade seria o espaço público caracterizado pela hipertrofia dos meios. Nela, a audiência, à deriva, estaria sempre em fuga, incerta, desatenta, rebelde ou intoxicada por informações. O 
interesse público não existe em si, de acordo com Faria, mas se constitui de um emaranhado de interesses.

"Quando a mídia é permeável a determinada mensagem, a diferença é significativa, pois implica reverberação, impacto e difusão em grande escala." (Faria, 2007)

A mediação dos meios de comunicação ocorre sob uma nova ótica, mais abrangente e muito mais rápida. Morais comenta que a Revolução Industrial praticamente fez cessar o tempo humano e instalou o tempo da máquina, que impõe os próprios ritmos, sem se interessar pela estruturação fundamental do ser humano. Um tempo de vertiginosas mudanças sociais e de ritmos antes desconhecidos. Época do fast food, do microondas, do sedex ultra-rápido, da internet, pois afinal é preciso correr. Sem a tecnologia que tornou o mundo mais eficiente, as sociedades complexas não têm mais como viver (Morais, 2004).

"De forma mais ou menos explícita a mídia não só está presente na configuração do mundo atual; ela é também um dos principais elementos desse organismo vivo e pulsátil (a Terra), que tem como sangue a informação. Eis por que as investigações a respeito da mídia constituem caminhos para que busquemos compreender a sutileza da trama deste nosso mundo. Tanto a produção midiática e sua história multifacetária, quanto a formação de seus usuários, são elementos esclarecedores sobre os tempos atuais - e cabe aos educadores a compreensão da atualidade e dos poderes da mídia." (Morais, 2004).

Especificamente no Brasil, a TV e mais recentemente a internet ocupam lugar de destaque. Morais afirma que a internet, em seus novos ângulos, com a educação, seus desejos, projetos e misteres cada vez mais "será parte da trama de nossas existências".

A grande importância da TV na sociedade brasileira é explicitada por diversos estudiosos em comunicação, por ser um lazer disseminado em todas as classes sociais, ainda com o advento da TV por assinatura. Baccega observa que a importância da TV é que "o espaço público começa e termina nos seus limites". O que não foi veiculado por ela não aconteceu, sendo os fatos selecionados por critérios de interesses diversos, da empresa ou da transformação do fato em espetáculo capaz de capitanear a atenção do público, "prendendo-o pela emoção" (Baccega, 2003 apud Morais, 2004). 


\subsection{Abordagem do tema mudanças climáticas na imprensa}

Há escassez dos cursos na área ambiental voltados para estudantes de comunicação ou jornalistas profissionais (Trigueiro, 2005). O investimento é muito mais pessoal, do que institucionalizado. O cenário estressante das redações pouco deixa tempo para o aperfeiçoamento dos profissionais. A exigência da cobertura sobre mudanças climáticas por si só já representa uma imenso desafio. $O$ profissional além de apurar precisa se atualizar constantemente sobre o que tem sido publicado e discutido sobre o assunto. Muito embora esta seja uma premissa do exercício da atividade do jornalista em seus mais variados campos.

Trigueiro observa que um exemplo da carência de profissionais com capacitação na área ambiental pôde ser notado na Rio-92. O novo filão meio ambiente demandava material. Para atender essa demanda, técnicos de diversas áreas tornaram-se colunistas e articulistas. Trigueiro também enfatiza nomes que fizeram história no jornalismo ambiental, como Washington Novaes, atualmente colunista de publicações - entre elas $O$ Estado de S. Paulo, analisado neste estudo - e profundo conhecedor da temática ambiental,.

Em uma revisão para a revista Science que analisou livros publicados sobre mudanças climáticas e o debate travado sobre o assunto, Kitcher diferencia três questões nos discursos: primeiramente, se as mudanças climáticas especialmente as ações que aumentam as emissões de GEE - estão contribuindo para um aquecimento da Terra. Em segundo lugar, sobre as probabilidades de que vários fenômenos vão ocorrer e quais serão as consequências para os seres humanos e outras espécies. Em terceiro lugar estão as considerações sobre o que deveria ser feito para combater o aquecimento e limitar os danos. Kitcher também mostra na literatura a respeito do tema alguns pontos que contribuem para a confusão do público estimulada pela mídia. "Aparentemente a ideia de expor a ciência ambiental como um duelo entre perspectivas de experts rivais é seduzente demais para se resistir" (Kitcher, 2010).

Em um trabalho que analisou de forma detalhada mais de 150 artigos sobre mudanças climáticas nos jornais The Guardian, The Independent, The Times e The Daily Telegraph entre 1997 e 2007, Doulton e Brown identificaram oito discursos característicos:

- Otimismo - mudança climática será benéfica; 
- Racionalismo - outras questões relacionadas ao desenvolvimento são mais importantes; deveríamos lidar com a mudança climática como ela ocorre;

- Mitigação ética - o ocidente deveria liderar;

- Mitigação certeira - posição de ameaça da Índia e China;

- Desastre - mostra o que já está acontecendo; algo precisa ser feito;

- Catástrofe potencial - ricos devem agir logo, mas não há necessidade de revolução;

- Crise - a única saída é uma revolução;

- Oportunidade - superar as mudanças climáticas pode ajudar os pobres.

Ao abordar as diferenças nas coberturas, Doulton e Brown (2009) afirmam que diferentes tipos de atores influenciam diferentes discursos. Um ator apenas, observam, pode ser particularmente importante em influenciar 0 surgimento de um discurso, como por exemplo Bjorn Lomborg e o racionalismo. Também observam que papers científicos são raramente utilizados como base para textos jornalísticos e que embora haja cobertura de imprensa para os relatórios do IPCC, particularmente dentro do discurso de catástrofe potencial, os relatórios são um processo político.

Doulton e Brown continuam explicitando que os cientistas são algumas vezes usados para legitimar histórias, podendo o trabalho dos mesmos formar a espinha dorsal de relatórios de ONG's. O estudo aponta que há ocasionalmente artigos jornalísticos escritos por um cientista. Quando os achados científicos são utilizados como base para textos jornalísticos, a tendência é que se concentrem em pesquisas que mostram menores ou maiores impactos das mudanças climáticas.

Observam os autores que fatores sociais, políticos e econômicos podem explicar a cobertura. Um aumento na cobertura pode ser reflexo de maior importância política do tema ou da preocupação do público com o assunto. Conclui a pesquisa que a imprensa acentua e perpetua as visões de países em desenvolvimento e os pobres como vítimas em face de desastres e de que eles podem ser ajudados pelos países ricos do ocidente (Doulton e Brown, 2009). 
No Brasil, a Agência de Notícias dos Direitos da Infância (Andi) promoveu o monitoramento de notícias publicadas em 50 jornais de 26 Estados brasileiros e do Distrito Federal entre julho de 2005 e junho de 2007 e julho de 2007 a dezembro de 2008. Este monitoramento detectou que referências ao contexto brasileiro aumentaram de $42,7 \%$ dos textos para $72,3 \%$, no segundo período analisado. Também a diminuição dos ganchos jornalísticos foi percebida em 2008. O mesmo trabalho identificou que a cobertura no primeiro período de investigação apontava os líderes mundiais como responsáveis por apresentar respostas para as mudanças climáticas; no segundo período de cobertura, a responsabilidade voltou-se para o Executivo brasileiro. O estudo também detectou uma tendência de diminuição da abordagem do tema por parte dos jornais a partir de 2007.

O estudo da Andi aponta também que a menção na mídia brasileira sobre causas e soluções relativas aos fenômenos climáticos se manteve estável entre os dois períodos. Causas das mudanças climáticas registrou $36 \%$ e soluções, 41\%. Por outro lado, a referência às consequências sofreu uma redução expressiva de 58,5\% (2005/2007) para 34,4\% (2007/2008).

Para estratégias de mitigação foi registrado aumento de 45,5\% para $51,1 \%$. Em 2005/2007 o foco foi o setor energético $(45,1 \%)$ e no período 2007/2008, o uso do solo e das florestas (25,4\%). Adaptação passou a ser tema abordado de forma mais frequente, saltando de $3,6 \%$ para $11,9 \%$. As temáticas mais fortemente vinculadas a mudanças climáticas foram GEE e questões energéticas. Na mesma pesquisa da Andi, entre julho de 2005 e junho de 2007, $46 \%$ dos textos selecionados fizeram alguma referência à energia; no segundo período analisado, o índice foi de 42,7\%.

É necessário observar que a discussão sobre energia ainda está concentrada na utilização dos combustíveis fósseis $(31,6 \%$ e 25,9\%, respectivamente). No debate em torno das energias limpas o uso do etanol ocupa $10 \%$ do universo pesquisado, com maior incidência de notícias sobre esse tema entre maio e junho de 2008, período em que a cobertura referente à $9^{\text {a }}$ Convenção da ONU sobre Diversidade Biológica (CDB) e a Climate Change Talks (evento promovido pela Convenção-Quadro das Nações Unidas sobre Mudança do Clima) ressaltou o empenho do governo do presidente Luís Inácio Lula da 
Silva em defender a cultura da cana-de-açúcar das acusações de que a produção de biocombustíveis poderia potencializar a crise mundial de alimentos.

Em geral, a cobertura do segundo período de monitoramento (20072008) se tornou mais voltada ao cenário nacional (Andi, 2008).

Um estudo realizado pelo jornalista britânico Mike Shanahan com 111 jornalistas de 35 nações em desenvolvimento concluiu que apenas $31 \%$ dos profissionais recebeu algum treinamento formal sobre o assunto. Os profissionais citaram a falta de cursos ou oficinas de capacitação como o grande gargalo na cobertura. Além dessa dificuldade, os principais pontos relatados foram:

- A falta de pesquisas sobre a realidade local e de especialistas locais preparados para falar com jornalistas;

- Dificuldades de acesso à informação e falta de compreensão do assunto;

- Dificuldade em convencer os editores sobre a importância de pautas sobre alterações climáticas;

- Insuficiência de recursos para viajar para áreas remotas ou para conferências relevantes sobre clima (Shanahan, 2009).

\subsection{Percepção pública sobre meio ambiente e mudanças climáticas}

No Brasil as pesquisas de opinião pública normalmente são realizadas por institutos especializados sob a encomenda de governos, instituições públicas e privadas. Crespo lembra que no Brasil tornou-se hábito a realização de pesquisas que procuram situar a opinião pública diante de fatos conjunturais, polêmicos ou de grande interesse. Em períodos eleitorais, as pesquisas sobre os candidatos a eleições recebem ampla divulgação nos meios de comunicação. Empresas também se utilizam das pesquisas de opinião para aferir sua imagem ou traçar estratégias de mercado.

Crespo explica que as pesquisas de opinião podem ser utilizadas como uma ferramenta para se medir fenômenos sócio-culturais, bem como instrumento para acompanhar acontecimentos de impacto na vida da população.

"Nos países de tradição democrática, a pesquisa de opinião tem sido um instrumento frequentemente empregado no processo de formulação de políticas públicas, funcionando como consulta à 
população sobre diversos assuntos de interesse público" (Crespo, 2005).

Nas questões relacionadas a meio ambiente países como Estados Unidos, Canadá, Inglaterra e França desenvolvem pesquisas de opinião há anos e possuem séries históricas de vinte, trinta e até quarenta anos. Mas para o Brasil, que viveu os anos de ditadura militar, as primeiras pesquisas de opinião ocorreram nos anos 1980, sobre os efeitos da industrialização vivida nos anos 1960 e 1970. As pesquisas versavam sobre a contaminação do ar em Cubatão e em São Paulo, porém nenhuma se tornou sistemática. Em outros temas, as pesquisas são pontuais.

Nos anos 1980, o Instituto Gallup americano iniciou uma pesquisa de opinião em vários países, simultaneamente, para verificar o quanto a população estava preocupada com os problemas ambientais globais, aponta Crespo. No Brasil, nenhuma iniciativa nesse sentido. A explicação, prossegue ela, é que a problemática ambiental não estava na agenda pública e também havia o custo de sondagens como essa, representativas de toda a população em um país como o Brasil, de extensão continental.

\footnotetext{
"Por que aqui alguém gastaria dinheiro e tempo para perguntar à população pouco escolarizada e cheia de necessidades básicas por satisfazer sobre um tema que ninguém sabia direito do que se tratava? Naquele tempo - tão pouco tempo, na verdade - os ambientalistas eram os "ecochatos", ou "xiitas verdes", e não faziam ministros nem secretários de estado. Eram uns românticos que pregavam amor à natureza, ou radicais que se opunham ao desenvolvimento que o governo e as empresas se propunham a produzir (usinas nucleares, hidrelétricas, desmatamento para urbanização ou plantação de soja, retificação de rios para torná-los navegáveis, etc.)" (Crespo, 2005).
}

A superexposição da temática ambiental antes, durante e depois da Conferência Rio-92 é apontada por Crespo como algo que contribuiu para um "fluxo de consciência pública". A extensão e aumento da densidade da vida política democrática foi fundamental para a modernização da gestão ambiental e progressivo crescimento do tema na agenda pública.

Em 1991, tem início o trabalho de se traçar um panorama sobre o que o brasileiro pensa da ecologia, a partir de uma pesquisa nacional de opinião. As 
pesquisas foram realizadas em 1992, 1997 e 2001 (próximo a conferências ambientais Rio-92, Rio+5 e Rio+10), voltadas a:

- entender o conceito de meio ambiente, segundo um repertório cognitivo e o nível de informação;

- mensurar o conhecimento sobre os problemas ambientais;

- mensurar a disposição da população em ajudar na solução dos problemas identificados;

- avaliar o desempenho dos atores e instituições com a responsabilidade ou missão de proteger o meio ambiente (Crespo, 2005).

A pesquisa mostrou que quanto mais alto o nível de escolaridade, mais consistente é o interesse, o conhecimento e a preocupação com as questões ambientais. Moradores de cidades médias e grandes são mais informados e interessados na causa ambiental. Pode-se inferir a partir dos dados obtidos que aumentando a escolaridade da população há mais chances de um compromisso maior com o que preconiza o desenvolvimento sustentável. Indivíduos mais velhos (55 anos ou mais) têm menor interesse e os mais jovens (16 até 22 anos) também se mostraram pouco interessados. Entretanto, a tendência vem sendo revertida talvez pela proliferação de programas de educação ambiental, normalmente nas escolas, ou porque 0 ambientalismo tornou-se algo politicamente correto, observa Crespo. Como resumo do perfil do brasileiro ambientalista ou simpatizante revelado na série histórica de 1992 a 2001, tem-se o indivíduo entre 22 e 45 anos, com alta escolaridade e que tem na televisão seu principal meio de informação sobre o assunto. Menos de $40 \%$ leem jornais regularmente e somente 15\% afirmam fazê-lo diariamente (Crespo, 2005).

$\mathrm{Na}$ última pesquisa nacional, $25 \%$ da população não era capaz de identificar um problema ambiental na sua cidade ou no país. Dentre esses, havia mais mulheres que homens, na proporção de $30 \%$ para $20 \%$. Os respondentes que não identificaram problemas ambientais estavam mais concentrados no Centro-Oeste $(36 \%)$ e Nordeste (35\%). No Norte e no Sudeste os percentuais foram respectivamente $21 \%$ e $20 \%$.

De acordo ainda com essas pesquisas da série histórica, o menos interessado nas questões ambientais mostrou ser predominantemente do sexo 
feminino, possuir baixa escolaridade (primário), ter 50 anos ou mais e morar no interior ou nas periferias urbanas. A pesquisa também mostrou que os brasileiros consideram o meio ambiente como sinônimo de fauna e flora. $O$ repertório cognitivo dos brasileiros é bastante restrito, deixando de lado algo que se relacione aos seres humanos e suas criações quando pensam em meio ambiente. O imaginário das pessoas é povoado pelos santuários ecológicos.

$\mathrm{Na}$ primeira pesquisa da série $\mathrm{O}$ que o brasileiro pensa... a pergunta por que proteger o meio ambiente e conservar os recursos naturais teve como resposta predominante "porque é bom para a saúde humana". A resposta por demais antropocêntrica indica o elo apreensível entre meio ambiente e ser humano. Crespo acredita que "possivelmente fortalecer os laços entre fatores que determinam melhor qualidade de vida, saúde e meio ambiente seja mais eficiente do que os apelos a uma consciência que busque estabelecer uma certa essencialidade na natureza ou um valor demasiadamente econômico aos recursos minerais". Há indicativos de que a consciência ambiental ainda é superficial (pensamento descolado da ação, atitude), mas também há indícios de que há uma evolução ao longo dos anos.

Ainda sobre a série de pesquisas, Crespo destaca que os principais problemas ambientais identificados - que permanece ao longo de toda a década - são: o desmatamento, no país ou no mundo; saneamento ambiental quando a referência é a cidade ou o bairro. Índices altos (22\%) para aqueles que não souberam opinar e para aqueles que responderam nenhum problema ao comentar sobre seu bairro (34\%). Afirma ela ainda que o enfrentamento dos problemas ambientais não é prioridade para os brasileiros e sim para parte das elites informadas, antenadas com as tendências de pensamento e comportamento globais. Para a população, desemprego, violência, carências de saúde e educação são as prioridades. Ao elegerem um ranking de problemas que merecem maior atenção, meio ambiente aparece na décima primeira posição. Mesmo entre os mais escolarizados, meio ambiente ocupa apenas o nono lugar. Nos países desenvolvidos, aponta, a posição oscila, de acordo com o momento. Em tempos de crise econômica as questões ambientais perdem posição (Crespo, 2005).

$\mathrm{Na}$ pesquisa do Instituto Gallup de 2009, que integra uma série histórica realizada há 25 anos, pela primeira vez os norte-americanos 
responderam que entre meio ambiente e crescimento econômico deveria ser dada prioridade ao crescimento econômico, mesmo que isso trouxesse consequências para o meio ambiente. Em 1984, 60\% das pessoas escolheu meio ambiente; em 2003 e 2004 essa percentagem ficou abaixo de 50\% (47 e 49\% respectivamente), registrando em 2009 42\% pela opção ambiental, enquanto crescimento econômico subiu para 51\%. A recessão econômica é apontada para essa reversão de prioridades (Newport, 2009).

Sobre o imaginário da temática ambiental no Brasil, Trigueiro destaca que edições do programa Globo Repórter, exibido em horário nobre da emissora de maior audiência na TV aberta do país, a Rede Globo, e outros programas do gênero na linha jornalística ou de documentário produzidos no Brasil ou importados de outros conglomerados mundiais - como a BBC e National Geographic - "parecem reforçar, mesmo que involuntariamente, a idéia de que meio ambiente é sinônimo de fauna e flora" (Trigueiro, 2005). A linha editorial do Globo Repórter investiu fortemente, a partir de 1998, em temas relacionados à natureza. Até janeiro de 2003 foram ao ar mais de 100 programas enfocando a temática vida selvagem, que alcançaram audiência com boa margem à frente daqueles apresentados pelas concorrentes no horário.

Destacando o caráter multidisciplinar da área ambiental, Trigueiro aponta como desafios para o jornalista traduzir os conteúdos sem prejuízo da informação, evitando o risco de ser "irritantemente didático e até pedante". Lembra ainda que a simplificação dos conceitos também traz o risco de comprometer a essência da informação que se quer divulgar. Por outro lado, o cientista tende a falar para os pares, afastando o público leigo. Além de explicitar o desafio com relação à semântica, Trigueiro lembra a questão do tempo de validade da notícia, um senso de urgência que permeia o processo de produção e consumo do factual.

Ao citar o artigo $4^{\circ}$ parágrafo $1^{\circ}$ da Convenção-Quadro das Nações Unidas sobre Mudança do Clima que define o compromisso dos países em desenvolvimento de "promover e cooperar na educação, treinamento e conscientização pública em relação à mudança do clima, e estimular a mais ampla participação nesse processo", Trigueiro enfatiza que este compromisso depende basicamente do apoio da mídia. Questiona também a falta de 
visibilidade do assunto na grande imprensa, referindo-se aos prazos das projeções climáticas.

"Numa sociedade cada vez mais imediatista, o que vai acontecer daqui a algumas décadas tem cada vez menos importância". (Trigueiro, 2005)

Porém a divulgação do quarto relatório do IPCC em 2007 - e portanto posterior à publicação do artigo de Trigueiro - alterou esse panorama. $\mathrm{O}$ assunto passou a ser constante no noticiário e a ampla cobertura trouxe questões recorrentes no jornalismo, como o risco do sensacionalismo, catastrofismo e a falta de preparo das redações para este desafio. A alta rotatividade nas redações, falta de profissionais qualificados e deficiências nas estruturas de trabalho, incluindo-se aí o número de profissionais envolvidos na cobertura de temas de alta complexidade (as redações cada vez mais "enxutas") completam o cenário. Por outro lado, o farto material de agências de notícias e as novas tecnologias de informação trazem um universo vasto de conteúdos.

Wolcott e Sengupta afirmam que ao mesmo tempo em que existe farta documentação sobre os benefícios de se integrar os sistemas que envolvem o conhecimento científico e o do público, a cultura científica ainda permanece distante do público em geral. A educação superior perdendo seu propósito primeiro de formar antes de mais nada cidadãos tem contribuído com a produção de duas realidades: a dos cidadãos que perderam a capacidade de se engajar com a ciência e a dos cientistas que perderam a capacidade de se engajar efetivamente com o público. Assegurar o engajamento de ambos em um novo processo requer mudanças em percepções e competências de todos os atores: comunidade científica, cidadãos e governos (Wolcott e Sengupta, 2010).

Em um trabalho que analisou a abordagem sobre o fenômeno efeito estufa em revistas e jornais não científicos de grande circulação e em livros paradidáticos, Xavier e Kerr verificaram que a grande maioria dos textos jornalísticos apresentou um tratamento inadequado do fenômeno e sua relação com mudanças climáticas globais.

"São muito comuns e equivocadas as abordagens catastrofistas deterministas. Transmitem em geral que estamos diante de um efeito maléfico, quando na verdade ele é importante para o desenvolvimento da biosfera e o que traz inquietação são as alterações observadas em seu padrão. Mesmo que essas abordagens tenham por objetivo alertar quanto a possível 
evolução do problema, elas são deseducativas e refletem uma tentativa de manipulação do público-alvo. Ao final pode-se terminar alimentando um efeito oposto, pois os sinais de mudanças climáticas são fracos do ponto de vista da percepção humana e lentos se considerada a duração de uma vida. Ao mesmo tempo elas podem não se consolidar, por força de fatores ainda não equacionados devidamente nos modelos climáticos disponíveis" (Xavier e Kerr, 2004).

Também detectaram que nos livros paradidáticos houve mais coerência com as hipóteses aceitas pela comunidade científica, mas ainda assim alguns autores deixaram de abordar certos aspectos importantes ou significativos. No que diz respeito aos textos jornalísticos, a maioria não usou tratamento adequado quando discutiu o efeito estufa como principal causador das mudanças climáticas. Também houve predomínio de uma visão catastrófica, causada pela confusão do efeito principal com sua variação, e a ausência de rigor científico no tratamento da questão. Alguns exemplos de erros encontrados foram distorções na previsões de consequências, falhas na indicação dos GEE, suas fontes naturais e antropogênicas, variação nos níveis de emissão. O estudo também sugere uso de assessoria na produção dos textos e encomenda de artigos a especialistas. Citando Olson (2000), afirmam que adotar o perfil sensacionalista chama mais atenção e resulta em mais vendas.

Uma abordagem interessante que chamou a atenção no trabalho citado diz respeito à percepção sobre o assunto, algo talvez do campo de psicólogos, sociólogos, comunicólogos e porque não cientistas embuídos da visão multidisciplinar e comprometidos com a divulgação científica. Vale destacar o trecho para uma reflexão:

"Independentemente da racionalidade científica com que analisamos o problema, a possibilidade de que venham catástrofes é algo muito presente no imaginário popular (...) Suas consequências localizadas são perceptíveis e determinadas (impermeabilização do solo e consequentes alagamentos, efeito ilha de calor, malefícios da poluição do ar, estresse urbano, etc). É intuitivo, portanto, que desastres globais também estejam se delineando mesmo que possa haver ainda muitas incertezas quanto aos resultados oferecidos pelos modelos científicos" (Xavier e Kerr, 2004).

Ao analisar o tema imaginário do aquecimento global, Dantas afirma que o efeito do aquecimento global traz oportunidade para a humanidade repensar sua relação com a natureza. Retrata ainda a mudança no ambientalismo, devido ao desafio imposto pelo aquecimento global, já que a 
questão passou a ser não mais apenas salvar espécies em extinção ou incentivar o convívio maior com a natureza, mas "assegurar a sobrevivência da civilização humana tal como a conhecemos para futuras gerações". O ambientalismo passou a não envolver apenas ativistas e passou a ter enfoque multidisciplinar, reunindo articulações e parcerias entre governos, comunidade científica, mídia e sociedade (Dantas, 2009).

Estudo desenvolvido com 1.250 estudantes de 166 universidades em 43 países mostrou que aspectos ecológicos, sociais e econômicos merecem ênfase especial e precisam ser considerados, ao invés do foco em aspectos técnicos, como tradicionalmente tem ocorrido. A maioria dos estudantes, de acordo com a pesquisa, está insatisfeita com seu nível de informação sobre mudanças climáticas. Para o autor do estudo, o professor Walter Leal Filho, da Universidade de Hamburgo, as mudanças climáticas não podem mais ser tratadas como um assunto de meteorologistas e físicos. A importância do debate entre universitários é fundamental, já que eles serão os futuros profissionais das áreas de ciências, educação, direito, engenharia, entre outras, e precisam estar conscientes sobre o impacto de suas profissões no que diz respeito à ameaça climática (Leal Filho, 2010).

Entre as motivações importantes para o engajamento desse público de universitários, algumas das razões citadas foram:

- Ocorrência de eventos locais e globais;

- Entendimento dos impactos de eventos geofísicos para comunidades locais;

- Vislumbrar a necessidade de ação global, regional e local contra as mudanças climáticas;

- Entender o papel da política no processo de resolução do problema;

- Aceitar a necessidade de governança para as mudanças climáticas;

- Consciência sobre as medidas de mitigação e adaptação;

- Visão crítica dos sistemas e contexto que exacerba os impactos das mudanças climáticas; 
- Distinção do papel entre instituições globais e governos nacionais;

- Uso de processos mentais para entender e interpretar as causas e consequências dos eventos relacionados ou resultantes das mudanças climáticas.

Na pesquisa, mudanças climáticas foram relacionadas a aumento do mar por $74 \%$ do público; aumento da pobreza por $67 \%$; danos à biodiversidade por 34\%; aumento de espécies extintas 22\%; derretimento de geleiras $29 \%$; aumento em tempestades para 27\%; aumento de secas para 31\%; aumento de conflitos $16 \%$; e $19 \%$ relacionam a mais fome em função da baixa fertilidade do solo (Leal Filho, 2010). 


\section{METODOLOGIA}

Parra e Santos afirmam que a pesquisa de campo tem como base observar os fatos tal como ocorrem. A consulta pode se dar por meio de questionário ou entrevista junto aos elementos envolvidos (Parra e Santos, 2003).

Após pesquisa preliminar, foram estruturados questionários a fim de balizar o estudo junto aos pesquisadores da área de mudanças climáticas, jornalistas das publicações selecionadas e público assinante dos periódicos em questão.

\subsection{Metodologia utilizada}

Como a proposta do trabalho foi a de analisar a cobertura do tema mudanças climáticas por um determinado período por parte da grande imprensa, em quatro publicações selecionadas, e a compreensão desse tema pelo público, passando pelos mecanismos de tradução e produção de conteúdos, optou-se por uma técnica combinada de análise. Pesquisa quantitativa, com indivíduos do público, ao mesmo tempo em que produtores de conteúdo tanto da esfera científica quanto do jornalismo foram selecionados, de forma a enriquecer a discussão. Esta última seleção seguiu o critério qualitativo. Foram selecionados jornalistas das publicações analisadas. Quanto aos cientistas, a seleção ocorreu pelos critérios de citação nas reportagens analisadas e pelas áreas diversificadas, porém conexas, em que estes atuam, de forma a possibilitar multiplicidade de visões.

Os anos de 2006 e 2007 foram escolhidos pela importância desse período na cobertura do tema e pela importância que representou a divulgação do relatório do IPCC para a área ambiental em geral e para a área de mudanças climáticas em particular. As publicações objeto de análise foram escolhidas pela tiragem representativa e alcance em termos de distribuição.

Na primeira etapa, foram selecionados nos jornais diários Folha de $\mathrm{S}$.

Paulo e O Estado de S. Paulo e nas duas revistas semanais Veja e Época os textos jornalísticos relacionados ao tema. Nesta seleção, foram identificados os textos que tratavam do tema como abordagem principal em qualquer dos cadernos ou editorias. Textos que apenas faziam referência às mudanças climáticas sem no entanto apresentar conceitos ou discussões relacionadas ao tema foram descartados. Para o jornal Folha de S. Paulo a seleção foi feita por 
meio de pesquisa no banco de dados do periódico. Para O Estado de S. Paulo, na impossibilidade de se adotar o mesmo critério pelo fato de o acesso ao banco de dados estar fechado ao público, optou-se por selecionar o material por meio de clipping eletrônico da agência noticiosa Radiobrás ${ }^{12}$ e ao mesmo tempo confrontar o material que se obteve com aquele constante no site do Jornal da Ciência ${ }^{13}$. Para a seleção dos textos de modo geral, foram adotadas palavras-chave para a busca:

- Aquecimento global

- Aquecimento do planeta

- Clima global

- Efeito estufa

- Emissões de $\mathrm{CO}_{2}$

- Emissões de carbono

- Gases estufa

- Inventário de emissões

- Inventário de carbono

- IPCC

- Painel Intergovernamental de Mudanças Climáticas

- Mudança(s) climática(s)

- Mudança(s) do clima

- Convenção do clima

- Conferência das partes/COP

- Gases de efeito estufa

- Eventos climáticos extremos

- Catástrofe climática

- Savanização

- Vulnerabilidade climática

Para a revista Veja, foi acessado pela internet o site da revista em que consta todas as edições digitalizadas e realizado levantamento de textos sobre mudanças climáticas. Para a Época, o levantamento foi solicitado ao centro de

\footnotetext{
${ }^{12} \mathrm{http} / / /$ clipping.radiobras.gov.br

${ }^{13}$ http://www.jornaldaciencia.org.br/busca.jsp
} 
documentação da publicação, já que o banco de dados não pode ser acessado por usuários externos.

Foram totalizados 677 textos. Após uma leitura cuidadosa, os textos dos jornais receberam uma denominação de acordo com seu discurso predominante. Essa espécie de rotulagem foi feita apenas para os textos da editoria de ciência, que foram divididos em subtemas:

Pesquisas sobre mudanças climáticas - quando, no texto, são apresentados resultados de pesquisas realizadas por instituição científica nacional ou internacional, e quando essa pesquisa seja o eixo norteador da notícia, tendo mais destaque os resultados aferidos e a comunicação desse conteúdo do que qualquer outro aspecto presente no texto;

Consequências ou efeitos das mudanças climáticas - quando a maior ênfase do texto recai nos resultados de conseqüências ou efeitos reais ou potenciais das mudanças do clima, em nível local ou global;

Política envolvendo mudanças climáticas - quando o foco principal do texto se relaciona a aspectos políticos, discussões, cobertura de processos decisórios do painel do clima da ONU ou política ambiental e debates conexos a essas questões;

Combate às mudanças climáticas em geral - quando no desenvolvimento do texto predominam as medidas relacionadas ao combate às mudanças climáticas, quais sejam medidas de redução de GEE, controle de emissões de poluentes de várias fontes que contribuem com o incremento do efeito estufa, adoção de legislação ou medidas legais que sirvam como controle de emissões;

Combate ao desmatamento - pela importância que assume o tema no país, a adoção de medidas ou discussões voltadas ao combate ao desmatamento como forma de conter o incremento do efeito estufa que gera as mudanças climáticas foi classificado em separado;

Mercado de carbono - a classificação foi adotada quando esse tema é o foco principal do texto, servindo com eixo central que norteia todas as outras informações constantes;

Impacto econômico - quando o destaque do texto é o impacto econômico que as mudanças climáticas acarretam ou podem acarretar; 
Impacto ao turismo - quando o destaque do texto é o impacto ao turismo que as mudanças climáticas acarretam ou podem acarretar;

Inventário de emissões - texto focado em levantamento de emissões de gases de efeito estufa;

Divulgação científica - textos estruturados no sentido de explicar conceitos científicos;

Al Gore - textos focados na figura do ex-vice-presidente norte americano Al Gore;

Variação climática natural - predominância de informações sobre variação climática natural;

Financiamento de projetos do clima - financiamento à pesquisa sobre mudanças climáticas;

Controvérsia sobre as mudanças climáticas - controvérsia sobre a existência de mudanças climáticas;

Alerta sobre aquecimento global - evento chamando atenção sobre as consequências das mudanças climáticas agravadas pelo homem.

Para a classificação adotada foram especialmente considerados os títulos, entretítulos e abertura da matéria, compreendendo o trecho inicial, particularmente os dois primeiros parágrafos. Frequentemente o texto apresenta a possibilidade de classificação em mais de um quesito. Para a adequação a uma das categorias, é adotado o critério quantitativo, de espaço dedicado à exposição. Reportagens que não puderam ser adequadas a nenhuma das categorias, foram dispostas em classificação mais específica, como por exemplo inventário de emissões ou divulgação científica.

Após essa classificação, foram contabilizadas as ocorrências e tabulados os resultados. Em seguida, foram contabilizados os textos presentes em outras editorias. Para cada jornal diário, as abordagens foram comparadas entre os anos de 2006 e 2007.

Os discursos e informações constantes em reportagens foram destacados e avaliados quanto a critérios de abordagem de conceitos corretos do ponto de vista acadêmico, ou seja, se não demonstravam incorreções técnicas.

A presença da componente nuclear como associação ao discurso sobre mudanças climáticas foi analisada, como parte do processo exploratório do conteúdo. 
Para as revistas, verificou-se como o assunto foi tratado e a frequência com que esteve no noticiário. Também foram selecionados infográficos e imagens utilizados como suporte para o entendimento do leitor a respeito do assunto, especialmente as capas publicadas. A referência a estudos científicos e fontes de instituições nacionais e internacionais foram buscadas nos textos publicados, de forma a elucidar o foco das abordagens.

\subsection{Pesquisa de campo}

Em uma segunda etapa, foram formuladas questões para os cientistas selecionados e jornalistas das publicações analisadas, com o objetivo de permitir entender como o tema mudanças climáticas tem sido abordado pela imprensa e como ele tem sido encarado pela comunidade científica. Traçar perspectivas e possibilidades de aproximação entre a ciência e a tradução de conteúdos para um público não especialista norteou o foco dos questionários.

Para os jornalistas, todas as entrevistas foram feitas por telefone, no primeiro semestre de 2010. Os profissionais da Folha de S. Paulo e da revista Época foram escolhidos por serem editores, sendo que a transferência de cargo na Folha fez com que fossem entrevistados o editor de Ciência por 6 anos e 0 então editor interino, que assumiu o cargo após trabalhar como repórter da editoria por 6 anos. Em O Estado de S. Paulo, pela estrutura diferenciada, em que não há caderno de ciência, mas o caderno Vida \&, que engloba vários temas incluindo ciência, foi entrevistado o repórter especial que há 10 anos trabalha na publicação e que participou de várias coberturas sobre mudanças climáticas. A revista Veja não aceitou participar deste estudo.

Os cientistas foram contatados no primeiro semestre de 2010 e responderam ao questionário por e-mail. Por solicitação, optou-se por não identificar as respostas aos seus autores. Foram ouvidos cinco cientistas da área, selecionados pela área em que atuam, pela familiaridade com o atendimento à imprensa e por já terem sido fontes para reportagens em vários veículos.

A partir da hipótese de aproximação entre o universo da ciência e do senso comum e a criação de uma opinião pública mundial em torno da temática ambiental, foi realizado um levantamento bibliográfico a respeito das pesquisas enfocando meio ambiente e sobre mudanças climáticas em particular, no Brasil e no exterior. Para isso, foram utilizadas bases de dados nacionais e internacionais. 
Além de buscar pesquisas sobre como a temática ambiental ou sobre mudanças climáticas têm sido compreendidas pelo público em geral, foi realizado levantamento a respeito de estudos com enfoque em análises de conteúdo de imprensa do ponto de vista qualitativo ou quantitativo.

Por fim, foram buscados assinantes das quatro publicações analisadas para responder a um questionário com perguntas abertas e fechadas sobre o tema. Os assinantes deveriam:

- ler pelo menos uma das publicações analisadas no formato impresso ou digital;

- ser moradores do Estado de São Paulo;

- ter pelo menos 16 anos completos.

Além disso, não poderiam:

- ser especialistas na área de meio ambiente;

- ser ligados ao setor nuclear;

- ser jornalistas.

A pesquisa com assinantes foi realizada no primeiro semestre de 2010 com 108 participantes. A forma de resposta ao questionário foi combinada, o que permitiu aumentar o número de participantes. Responderam de forma imediata ao questionário impresso $19 \%$ dos participantes, outros $70 \%$ por e-mail e cerca de $11 \%$ foram aplicados pessoalmente - o participante foi respondendo de forma livre à entrevistadora, que registrava as respostas.

Tabulados os dados, foram verificados quais os aspectos comuns nesse grupo e como o tema tem sido compreendido. Por ser um público seleto, com acesso à informação qualificada, os participantes fornecem importantes subsídios sobre como a informação científica e, em particular, a cobertura ambiental sobre mudanças climáticas tem sido recebida junto a formadores de opinião. 


\section{RESULTADOS E DISCUSSÃO}

Conforme apresentado no capítulo sobre metodologia, os textos dos jornais diários foram selecionados e receberam uma classificação, somente para fins didáticos. Após uma leitura cuidadosa, receberam uma denominação de acordo com seu discurso predominante. Essa espécie de rotulagem foi feita apenas para os textos da editoria de ciência. Os critérios para a nomenclatura adotada foram explicitados no capítulo metodologia.

\subsection{Informação científica na imprensa}

Nos jornais diários, a editoria que publica reportagens sobre ciência pode ser exclusivamente dedicada ao tema ou pode contemplar vários assuntos, dentre eles ciência. Na Folha de S. Paulo, que registra circulação de 295.558 exemplares por dia $^{14}$, a editoria recebe 0 nome de Ciência e dispõe de outros espaços que veiculam temas de ciência e meio ambiente, de forma difusa. $O$ caderno Mais, publicado aos domingos, traz artigos dessa temática.

Em O Estado de S. Paulo, com circulação de 212.844 exemplares por $\mathrm{dia}^{15}$, a editoria chamava-se Vida \&, no período analisado (2006-2007), passando a se chamar Vida no início de 2010, veiculando temas de ciência, tecnologia, meio ambiente e educação.

Dados do Índice de Verificação de Circulação (IVC) indicam em aproximadamente 12,8 milhões o número mensal de leitores de jornais pela internet $^{16}$, consideradas visitas únicas, em janeiro de 2009.

Para as revistas, Veja é a que possui maior tiragem, com 1.083.742 exemplares (dados de 2010) ${ }^{17}$, segundo o IVC. A revista Época é a segunda revista semanal em circulação com 409.028 mil exemplares ${ }^{18}$.

\subsubsection{Análise de textos jornalísticos sobre mudanças climáticas}

Foram selecionados textos relacionados ao tema mudanças climáticas publicados entre os anos de 2006 e 2007, de quatro periódicos, sendo duas

\footnotetext{
${ }^{14} \mathrm{http}: / / \mathrm{www}$.anj.org.br/a-industria-jornalistica/jornais-no-brasil/maiores-jornais-do-brasil.

15 Idem

${ }^{16} \mathrm{http}$ ///www.anj.org.br/a-industria-jornalistica/jornais-no-brasil/leitura-online-dos-jornais.

${ }^{17} \mathrm{http}: / /$ www.aner.org.br/Conteudo/1/artigo42424-1.asp.

${ }^{18}$ Idem'
} 
revistas semanais, Veja e Época, e dois jornais diários, Folha de S. Paulo e O Estado de S. Paulo. O período foi escolhido pelo marco que representou na divulgação do tema para o grande público.

Nestes anos, destacam-se os seguintes fatos:

- Cruzada empreendida pelo ex-vice-presidente norte americano Al Gore, pelo convencimento sobre a gravidade das mudanças climáticas, com a divulgação do filme "Uma Verdade Inconveniente", produção apresentada em Cannes em maio de 2006 e que estreou no Brasil no dia 2 de novembro daquele ano. Gore, que esteve no Brasil em outubro divulgando o filme e o livro homônimo, afirmou que "políticos, ecologistas ou não, só serão capazes de fazer mais ou menos dependendo de como as pessoas se sentem em relação à crise".

- Publicação do Relatório Stern, divulgado em 30 de outubro de 2006, estudo encomendado pelo governo britânico a Nicholas Stern, chefe do serviço econômico do governo e ex-economista chefe do Banco Mundial, demonstrando impactos econômicos relacionados à crise climática.

- Realização da COP-12, em Nairóbi, Quênia, em novembro de 2006.

- Divulgação da primeira parte do quarto relatório do IPCC (AR4), produzida pelo grupo de trabalho I (Bases das Ciências Físicas), no dia 2 de fevereiro de 2007, em Paris.

- Divulgação da segunda parte do quarto relatório do IPCC (AR4), produzido pelo grupo de trabalho II (Mitigação), no dia 6 de abril de 2007, em Bruxelas.

- Divulgação do terceiro capítulo do quarto relatório do IPCC (AR4), na sede da ONU em Bangcoc, Tailândia, no dia 4 de maio de 2007, produzido pelo grupo de trabalho III (Impactos, Adaptação e Vulnerabilidade).

- Outorga do Prêmio Nobel da Paz de 2007 ao IPCC e a Al Gore, em outubro de 2007.

- Divulgação do relatório-síntese do IPCC, envolvendo os três grupos de trabalho, no dia 17 de novembro, em Valencia, Espanha. 
- Realização da COP-13, em Bali, Indonésia, em dezembro de 2007.

\subsubsection{Ano de 2006}

Para o jornal diário Folha de S. Paulo (FSP), em 2006, foram analisados 125 textos de Ciência, 18 de Opinião, 10 de Mundo, 9 de Dinheiro, 5 de Ilustrada, 3 de Brasil, 3 Mais, 2 Cotidiano, 2 Turismo, um de Esporte, um Caderno Especial - Guia de profissões. Os 125 textos da editoria Ciência estão distribuídos em temas conforme demonstrado na TAB. 4.1.

TABELA 4.1 - Textos sobre mudanças climáticas da editoria de Ciência da FSP em 2006.

\begin{tabular}{lc}
\hline Tema & Incidência \\
\cline { 2 - 3 } Pesquisas sobre mudanças climáticas. & $33 \%$ \\
\cline { 2 - 3 } Consequências ou efeitos das mudanças climáticas & $21 \%$ \\
\hline Políticas envolvendo mudanças climáticas. & $20 \%$ \\
\hline Enfrentamento das mudanças climáticas em geral & $6 \%$ \\
\hline Combate ao desmatamento & $5 \%$ \\
\hline Mercado de carbono & $2 \%$ \\
\hline Impacto econômico & $2 \%$ \\
\hline Impacto ao turismo & $2 \%$ \\
\hline Outros & $9 \%$
\end{tabular}

Percebe-se, portanto, que as pesquisas sobre mudanças climáticas foram a abordagem principal com $33 \%$, seguida por conseqüências ou efeitos das mudanças climáticas com $21 \%$. Políticas envolvendo mudanças climáticas foi a abordagem principal em $20 \%$ dos textos, seja política de modo geral seja política ambiental. Há predominância de enfoque em políticas mundiais em relação à política nacional.

Na nota da editoria de Ciência de 10/01/2006 "Lixo tóxico cria ursos polares hermafroditas", efeito estufa foi utilizado como sinônimo de aquecimento global. Percebe-se pela análise dos textos publicados pela imprensa que em geral esta associação se tornou comum.

$\mathrm{Na}$ nota de 17/04/2006, na mesma editoria, um exemplo do apelo emocional do tema, tendo em vista consequências para a fauna: 


\section{“Efeito estufa deixa morsas órfãs}

Cientistas que descobriram um número surpreendente de bebês morsas abandonados dizem que a culpa pode ser do aquecimento global. Segundo estudo na revista "Aquatic Mammals", as mães morsas abandonam os filhotes na banquisa para acompanhar o limite do gelo marinho, que derrete cada vez mais rápido."

Um outro exemplo de como o termo efeito estufa foi utilizado na Folha, em 22/05/2006:

"Avanço do agronegócio mudou perfil do desmate, diz cientista

(...)Essa mudança tem implicações diretas -e desagradáveis- para as emissões brasileiras de gás carbônico (CO2, o maior vilão do efeito estufa). A devastação da Amazônia lança todo ano 200 milhões de toneladas do gás na atmosfera.

Antes da mecanização, a floresta derrubada podia passar até 20 anos se decompondo, liberando lentamente o carbono estocado em forma de matéria vegetal. Parte dessa perda era compensada por rebrota.(...)"

$\mathrm{Na}$ edição de 27/05/2006, efeito estufa foi mencionado como algo negativo no título "Acordo contra efeito estufa terá uma nova fase após 2012".

\section{"Acordo contra efeito estufa terá uma nova fase após 2012}

Da Redação - Representantes de 165 países concordaram ontem que os controles climáticos devem continuar mesmo depois da expiração do Protocolo de Kyoto, em 2012. Essa é a data limite para que 35 países ricos reduzam em pelo menos 5,2\% em relação aos níveis de 1990 suas emissões de gases causadores do efeito estufa, apontado como o responsável pelo aquecimento global(...)".

Em 15/06/2006, novamente o uso equivocado da expressão combate ao efeito estufa, no texto "G8 não pode deixar clima de lado, dizem cientistas".

\section{“G8 não pode deixar clima de lado, dizem cientistas}

(...)No ano passado, na Escócia, o G8 havia prometido fazer do combate ao efeito estufa uma prioridade. Agora, a questão do suprimento de energia passou a ter prioridade máxima.

Segundo Krieger, os governos devem apostar na multiplicidade das fontes energéticas (do nuclear ao etanol), tentando ao mesmo tempo diminuir emissões de gás carbônico (...)."

Em 28/06/2006, a expressão efeito estufa foi utilizada como sinônimo de aquecimento global.

"Efeito estufa turbinou furacões de 2005

Estudo fornece evidência concreta para ligar o aquecimento global ao Katrina e a outros eventos climáticos intensos 
Parcela humana da culpa pela alta temperatura nas águas atlânticas -energia que alimenta os ciclones- é de $50 \%$, dizem cientistas

Rafael Garcia
Da Reportagem Local

Um estudo publicado ontem por uma dupla de climatologistas oferece dados concretos para aquilo que ambientalistas vinham tentando fazer desde o final do ano passado: culpar o aquecimento global pela temporada de furacões devastadores em 2005.

O trabalho, escrito por Kevin Trenberth e Dennis Shea, do Centro Nacional para Pesquisa Atmosférica dos EUA, calcula que ações humanas foram a razão de metade do aumento da temperatura média das águas do Atlântico Norte tropical $(+0,9 C)$. Foi esse o fenômeno que ofereceu combustível para eventos climáticos intensos, como o furacão Katrina, que devastou Nova Orleans em setembro do ano passado.(...)"

No texto de 22/09/2006 houve a abordagem do tema impactando outras áreas. Novamente efeito estufa, no título, foi utilizado de forma equivocada, como algo maléfico.

"Efeito estufa prejudica o turismo, diz relatório

Mudanças acontecerão em pouco mais de 10 anos

Do Independent - Alguns dos principais sítios turísticos do mundo podem ser destruídos num futuro próximo pelo aquecimento global, afirmou um relatório divulgado ontem avaliando os perigos da mudança do clima sobre o turismo de massas.

O relatório, intitulado "Futuro das Viagens no Mundo", afirma que em 2020 as características naturais de algumas maravilhas do mundo serão danificadas, enquanto outros ficarão superlotados.

Em pouco mais de uma década, o aquecimento projetado acabará com as praias de Goa (Índia) e levará a furacões mais intensos sobre os Everglades (EUA), enquanto uma horda de esquiadores invadirá o antes remoto reino do Nepal em busca de neve, que será escassa nos Alpes e em montanhas baixas.

Em particular, o relatório alerta que a mudança climática esquentará muitas das cidades turísticas do Mediterrâneo, como Atenas -cujas temperaturas subirão facilmente aos 40C, causando noites "insuportavelmente" quentes. A Toscana e a costa Amalfi, na Itália, sofrerão mais ondas de calor (o efeito é previsto para grande parte da Europa e América do Norte), com um número maior de dias secos e maior risco de incêndios.(...)"

Efeito estufa continuou a ser tratado como algo maléfico e como sinônimo de aquecimento global, conforme pôde ser verificado em outros exemplos, também da editoria de Ciência.

\section{"EUA mudarão política de clima, diz Gore}

(...)O acordo internacional contra o efeito estufa vinha sendo mantido em banho-maria pela administração Clinton, com resistência do Senado, e foi 
rejeitado de vez por George W. Bush em 2001, levantando o planeta contra os Estados Unidos.(...)" - 18/10/2006

\section{"Brasil é segundo no mercado de carbono}

País fica atrás da Índia na lista de nações em desenvolvimento que mais "vendem" projetos para combater efeito estufa - 13//11/2006"

Outros espaços do jornal trouxeram textos informativos, porém mais trabalhados e com possibilidades de uso de linguagem e estruturação bastante particulares. Levar informação e promover conscientização sobre as mudanças climáticas pode exigir habilidades variadas. No texto do Caderno Mais de 3/09/2006, um exemplo extraído do jornal francês Le Monde. Uma construção que utilizou figuras de linguagem persuasivas e mexeu com o imaginário sobre o aquecimento global.

\section{"No calor da Groenlândia}

Aquecimento das águas diminui geleiras, compromete modo de vida da população e põe em risco clima mundial

\section{Gaólle Dupont}

É uma paisagem enganadora. À beira da calota glacial da Groenlândia, tudo parece perfeitamente imóvel. Nada além de pedra e gelo, até onde a vista alcança. Onde está o céu? Onde fica a terra? E o mar? Nesse cenário imenso, as referências habituais desaparecem. A oeste, o deserto de neve ofuscante estende-se até o horizonte. A leste, um gigantesco rio petrificado, a geleira Helheimgletscher, desce até um fiorde, emoldurada por duas altas montanhas.

Primeiramente liso como uma nuvem, o gelo se contorce e racha ao avançar para o mar, onde grandes icebergs se destacam, rapidamente aprisionados pela banquisa. Não vemos a água do fiorde. O gelo de água doce e o da água do mar, misturados, formam na superfície um espesso magma branco cheio de arestas.

Nenhum indício do fantástico movimento que está em operação. No entanto, a calota glacial se move. Ela derrete. Apurando o ouvido, percebemos o som de uma grande torrente de montanha: é a água que corre embaixo da geleira. (...)".

Dentro da importância da divulgação científica, da simplificação dos conceitos e das ideias suscitando discussões, o texto de Marcelo Gleiser, colunista do jornal, na editoria de Ciência em 30/04/2006, merece destaque. Gleiser é professor de física teórica do Dartmouth College, em Hanover (EUA).

\section{Marcelo Gleiser: Dia da Terra: um guia para os perplexos}

(...)Fica difícil saber em que acreditar, especialmente porque construir uma nova conscientização global de preservação do planeta pode exigir mudanças custosas em informar e educar a população, em monitorar indústrias e 
plantações, o uso de poluentes, o controle dos esgotos, do lixo, das emissões dos carros, caminhões, navios, aviões.

O que fazer? Existem três possibilidades. Uma é deixar para lá essa história de tomar conta do planeta e se preocupar só quando o problema for realmente óbvio e irremediável. Péssima escolha. Outra é tentar filtrar do mundo de informação que recebemos as que são de fato confiáveis e não tendenciosas. Essa possibilidade é meio difícil pois, a menos que sejamos especialistas no assunto, não sabemos a priori em quem acreditar. A terceira, que me parece a mais sábia, é usar o bom senso. Talvez uma analogia entre a Terra e a nossa casa seja útil. Começamos com a casa limpa, abastecida e com o número de pessoas ideal para que todos possam viver com conforto. O número de pessoas cresce, o espaço aperta, a demanda por água e alimentos aumenta.

Um número maior de pessoas implica em aumento no consumo de energia e na produção de lixo. Ainda por cima, alguns habitantes gostam de fumar, enchendo o ar de poluentes. A solução é impor regras contra o fumo em excesso, reduzir o lixo e o consumo de energia. Caso contrário, a casa original rapidamente não daria conta da demanda crescente dos seus habitantes.

A Terra é bem maior do que uma casa mas também é finita. A atmosfera, os oceanos e o solo reciclam eficientemente a poluição e o lixo que criamos. Mas todo sistema finito tem um limite. Não há dúvida de que, se não mudarmos o modo como usamos e abusamos do planeta, acabaremos chegaremos a esse limite. Infelizmente, a ciência não pode prever exatamente quando isso vai ocorrer. Mas ela, junto com o bom senso, afirma que é uma mera questão de tempo."

A figura de catástrofe foi utilizada no noticiário em geral, como no exemplo a seguir, de 13/06/2006, editoria Mundo. No mesmo texto, o uso da energia nuclear para geração energética apareceu como ameaça, tendo em vista seu potencial como "tecnologia conversível em arma de destruição em massa".

\section{"Estudo nega que terror seja maior ameaça}

Cientistas de Oxford afirmam que catástrofe do aquecimento global pode gerar mais tensão e guerras

Da Redação - No final de 2003, pesquisa concluída pelo Pentágono mencionou a possibilidade de uma "catástrofe global que custaria milhões de vidas em guerras e desastres". Referia-se aos efeitos do aquecimento do planeta, problema que o governo de George W. Bush diz ser "um mito". O episódio, que reflete um prognóstico alarmante e a ausência de sensibilidade política para levá-lo a sério, é citado em relatório divulgado ontem, no Reino Unido, pelo independente Grupo de Pesquisa de Oxford, em documento intitulado "Respostas Globais para Ameaças Globais, Segurança Sustentável para o Século 21".

O argumento de seus três autores -Chris Abbott, Paul Rogers e John Sloboda- é de que a "guerra ao terrorismo" não é o melhor instrumento para garantir às próximas gerações um mundo mais seguro.

Muito pelo contrário, afirmam. Embora centenas de bilhões de dólares tenham sido gastos, foram recrutados terroristas em número maior que o neutralizado por atividades repressivas. Além do mais, a guerra ao terrorismo desviou a atenção de questões que, essas sim, podem gerar futuros conflitos de maior gravidade. 
O aquecimento global é um deles, dizem os autores. Citam relatórios de especialistas para os quais dentro de 20 anos a atmosfera estará saturada de poluentes, o que gerará mudanças radicais no clima. Isso provocaria o deslocamento maciço de populações de áreas litorâneas e de deltas dos grandes rios que o mar poderá inundar. Haveria queda na oferta de alimentos, imigração em patamares inéditos, tensões sociais e guerras. $O$ estudo cita ainda entre as causas de futuros conflitos a concorrência em torno do petróleo, com reservas concentradas no Oriente Médio.

Essa pressão não diminuirá com a construção maciça de reatores termonucleares. A energia nuclear, afirma, cria uma tecnologia conversível em arma de destruição em massa e é alvo potencial de radicais.

É necessário partir para fontes de energia renováveis, com políticas energéticas "sustentáveis" que economizem e deixem de depender de regiões cujas jazidas inevitavelmente gerariam novas guerras.(...)"

A dimensão ética do problema apareceu em nota produzida na edição de 31/08/2006, editoria de Ciência. Um encontro com o objetivo de discutir as dimensões éticas das mudanças climáticas ocorreu na cidade do Rio de Janeiro. O assunto foi descrito na reportagem como "aparentemente transcendental".

"Grupo quer regras mais éticas para discutir corte de emissão

\author{
Claudio Angelo \\ Enviado especial ao Rio
}

Um grupo de especialistas se reúne até hoje no Rio de Janeiro para debater um tema aparentemente transcendental: como o mundo pode agir de maneira ética em relação à mudança climática. A idéia do grupo é incluir nas negociações internacionais sobre o aquecimento global noções de igualdade e justiça que geralmente são ofuscadas por argumentos econômicos. Um exemplo é a responsabilidade por desastres naturais, que tendem a aumentar com a mudança climática e a afetar mais os países pobres (que emitem pouco gás carbônico e, portanto, são menos responsáveis pelo aquecimento) que os ricos. Quem paga pelo afundamento das nações-ilhas do Pacífico ou pelas secas na África e no Nordeste brasileiro? Ironicamente, a discussão vem sendo liderada por alguém que até poucos anos atrás representava justamente o país mais antiético do debate climático: Donald Brown, ex-subsecretário de Estado dos EUA e negociador-chefe do governo Bill Clinton na Convenção do Clima das Nações Unidas na época em que os EUA assinaram (mas nunca chegaram a ratificar) o Protocolo de Kyoto, em 1998.(...)"

Na editoria Brasil, duas reportagens foram publicadas, em novembro, e uma nota em dezembro sobre a contribuição das hidrelétricas para o aquecimento global. Na reportagem de 6/11/2006, editoria Brasil, intitulada "Mundo perdeu dez anos ao ignorar mudança do clima", produzida a partir de uma entrevista com Achim Steiner, diretor-executivo do PNUMA, a afirmação de que o fenômeno mudanças climáticas teria ocupado lugar de destaque no imaginário do público, pelo filme do ex-vice-presidente dos EUA AI Gore, "Uma Verdade Inconveniente", 
e pelas evidências "de que o fenômeno já está acontecendo e terá impactos econômicos graves".

$\mathrm{Na}$ editoria Opinião, cinco editoriais e 12 artigos assinados. Os editoriais versaram sobre um ano da entrada em vigor do protocolo de Quioto; efeitos das mudanças climáticas; a posição oficial brasileira nas negociações internacionais (proposta de fundo para financiar queda de desmatamento); custos das mudanças climáticas, a partir dos estudos econômicos do relatório Stern; emissões de gases estufa em países pobres e resistências desses países com relação às metas de redução. Este último editorial, de 11/11/2006, faz menção às usinas nucleares e aos lobbies no Planalto "para ressuscitar usinas nucleares". Um artigo assinado por Othon Pinheiro da Silva na seção Tendências/Debates em favor da opção nucleoelétrica defendeu "o momento do sim" para as usinas nucleares.

Reportagem da editoria llustrada de 17/02/2006 mencionou que a principal reportagem da Revista Vogue, "a bíblia dos fashionistas", tratou do aquecimento global e do modo como ele afeta o guarda-roupa de inverno no hemisfério Norte, tornando-o mais leve.

$\mathrm{Na}$ editoria de Esportes uma única reportagem, de 22/12/2006, abordou o cancelamento de etapas da Copa do Mundo de esqui nos Alpes, "uma das regiões mais afetadas pelo aquecimento global". Também foram mencionadas as medidas para compensar emissões e iniciativas de equipes de esportistas para conter emissões de gases de efeito estufa. No texto, foi descrito que haveria "um aquecimento médio de $2 \mathrm{C}$ a $6 \mathrm{C}$ decorrente do efeito estufa". A simplificação sem explicação do que os valores representam e a atribuição equivocada do aumento da temperatura ao efeito estufa induzem a um erro de compreensão do conteúdo científico para os leitores. Trata-se de uma referência aos diferentes cenários de emissões de GEE provocando maiores ou menores impactos na temperatura do planeta.

A mesma questão das pistas de esqui já havia aparecido no primeiro semestre do ano, no caderno de Turismo, edição de 6/04/2006. Foram apresentados estudos de cientistas dizendo que as pistas de Chacaltaya poderiam desaparecer devido às mudanças climáticas.

No caderno Mais foram publicados três textos sobre o tema, sendo dois em setembro e um em novembro. O texto "No calor da Groenlândia", de 
3/09/2006, impressionou pela riqueza de detalhes e histórias envolventes. O texto foi publicado no Le Monde, e permitiu aproximação com a realidade da população local, afetada pelo aquecimento das águas "que diminui geleiras, compromete modo de vida da população e põe em risco clima mundial”. Um trecho é transcrito a seguir:

"Karl Pivat, um caçador de 73 anos, descreve sem hesitar, com o dedo pousado num mapa, as mudanças causadas pela recente alteração climática. "Antes havia muito mais gelo e neve em todo lugar", diz o ancião. "Nós vimos as geleiras encolherem cada vez mais. A banquisa também está mais fina." Ele está enraivecido com os países ricos, que, ao emitirem gases do efeito estufa em excesso, são responsáveis por essa situação? "Essa pergunta não tem sentido para Karl", explica Anders Stenbakken, o diretor do departamento de turismo, que serve de intérprete. "Ele não procura a causa. Ele constata a mudança e se adapta a ela. A maioria dos groenlandeses sem dúvida teme menos o aquecimento climático que os ocidentais. Eles sabem que o homem é vulnerável à natureza e sempre a enfrentaram."

O velho já viu outras mudanças. Ele nasceu numa casa de pedra e turfa, cujas aberturas eram fechadas com a ajuda de intestinos de focas. Quando criança, sua mãe the contava as histórias do velho mundo, evocações de caças heróicas, longas celebrações e mortes violentas desses tempos conturbados. Seu pai caçava de caiaque, com arpão. Ao longo de décadas, Karl viu surgirem "os fuzis de caça, o rádio, as canoas a motor". "Temos conforto, televisão. Não passamos mais fome!", afirma. Depois de tantas revoluções, alguns graus a mais não o impressionam muito."

Para o jornal O Estado de S. Paulo (OESP), em 2006, foram analisadas 33 reportagens da editoria Vida \&, 12 artigos da seção Espaço Aberto, 6 artigos de Opinião, 3 reportagens de Economia e 1 Editorial, este abordando mudanças climáticas como assunto transverso, não como foco principal. Os temas veiculados na editoria Vida \& estão representados na TAB. 4.2.

TABELA 4.2 - Textos sobre mudanças climáticas da editoria Vida\& de OESP em 2006.

\begin{tabular}{ll}
\hline Tema & Incidência \\
\cline { 2 - 2 } Políticas envolvendo mudanças climáticas & $33 \%$ \\
\hline Pesquisas sobre mudanças climáticas & $21 \%$ \\
\hline Enfrentamento das mudanças climáticas em geral & $15 \%$ \\
\hline Consequências ou efeitos das mudanças climáticas & $9 \%$ \\
\hline Mercado de carbono & $9 \%$ \\
\hline Impacto econômico & $6 \%$ \\
\hline Panorama de emissões & $3 \%$ \\
\hline Outros & $3 \%$ \\
\hline Elaborada pela autora & $1 \%$ \\
\hline
\end{tabular}


O texto "País é o 34ํㅜ em ranking de condição ambiental", da editoria Vida\&, de 24/01/2006, chamou atenção, por abordar uma pesquisa das Universidades de Yale e Columbia, nos EUA, que classificou vários países em um ranking, de acordo com a qualidade ambiental relacionada a ecossistemas e à saúde humana. O estudo considerou indicadores como qualidade do ar, recursos hídricos, infraestrutura sanitária, mortalidade infantil, energias renováveis, conservação da biodiversidade e emissões de gases do efeito estufa. No estudo, - Brasil ficou em 4ํㅡ nas Américas e em 34ํ na classificação global, atrás de Argentina $\left(30^{\circ}\right)$, Chile $\left(26^{\circ}\right)$ e Colômbia (17ํ).

Nas citações à energia nuclear nos textos analisados, vale destacar reportagem de 30/09/2006, "Uma receita para clima melhor: estagnação", da editoria Vida\&, sobre um estudo desenvolvido por consultoria internacional a respeito do impacto econômico de reduções de emissões em nível suficiente para afastar a ameaça do aquecimento global. O relatório dizia que a energia nuclear podia ter papel importante, mas não crucial.

Nova referência à energia nuclear, em texto do jornal The New York Times, reproduzido na edição de 17/12/2006, editoria Vida\&, com o título "Cruzada pela cobrança de $\mathrm{CO}_{2}$ emitido". Na reportagem, afirmou-se que a ideia de cobrar pelo $\mathrm{CO}_{2}$ emitido "tem apoio de quem produz eletricidade a partir de reatores nucleares - isentos de carbono".

O uso do termo efeito estufa como algo que deve ser combatido ou como sinônimo de aquecimento global pôde ser identificado em textos ao longo de todo o ano de 2006. Na cobertura da COP-12, parte do texto da reportagem de 18/11/2006 "Decisões sobre clima são adiadas para 2008", que também mencionou o combate ao efeito estufa, é transcrita a seguir:

"A $12^{a}$ Conferência das Partes da Convenção-Quadro da ONU sobre mudanças Climáticas terminou ontem em Nairóbi, no Quênia, com uma agenda de decisões adiada para 2008. Deixou ao menos mais portas abertas do que fechadas para se combater o efeito estufa e o aquecimento da Terra. (...)"

No texto "Conservação poderá gerar lucro", de 28/11/2006, ao tentar explicar conceitos e termos relacionados às mudanças climáticas, há uma afirmação pouco precisa e confusa, não relacionando de forma clara os conceitos efeito estufa e aquecimento global. Também não fica claro que o gás carbônico é um gás de efeito estufa e o papel do carbono neste sistema. 
"O carbono é um dos elementos que, acumulados na atmosfera, promovem o efeito estufa e o aquecimento global. A principal fonte hoje no mundo é a queima de combustíveis fósseis, como petróleo e carvão, especialmente nos países desenvolvidos.

Porém, o corte e a queima da mata converte o carbono estocado na floresta em um gás-estufa. É justamente essa prática que coloca o Brasil entre os maiores emissores do mundo."

$\mathrm{Na}$ seção Espaço Aberto, especialmente os textos de Washington Novaes (jornalista há 53 anos - muitos deles dedicados à cobertura de temas de meio ambiente -, com importantes passagens pelos principais veículos de comunicação, atualmente colunista, consultor de jornalismo e produtor independente) trazem forte conteúdo informativo - com base em pesquisas científicas e jornalísticas - e primam pela precisão no uso da linguagem. Outros especialistas de várias áreas do conhecimento se utilizaram do espaço para abordar as mudanças climáticas.

José Goldemberg, físico, professor emérito da USP, em artigo de 17/01/2006, "A renascença da energia nuclear", criticou os custos do setor nuclear, enfatizando que é fraco o argumento de que energia nuclear não contribui para a emissão de gases que provocam o aquecimento da Terra, como as usinas termoelétricas, que queimam carvão, derivados de petróleo ou gás. No texto, afirma Goldemberg:

“(...) Para tornar a energia nuclear competitiva seria necessário dar ao carbono um valor de mais de US\$200 por tonelada, enquanto ele está sendo comercializado hoje por menos de US\$10 por tonelada. Por esse motivo, alguns ecologistas têm até se manifestado a favor da energia nuclear, como James Lovelock, mas a própria publicidade dada a declarações de ecologistas que antes eram contrários à energia nuclear e agora mudaram de idéia torna esta "conversão" um tanto quanto suspeita. Por trás disso há provavelmente uma guerra entre os produtores de carvão e gás natural - que não querem perder o seu mercado tradicional de suprir usinas termoelétricas $e$ as indústrias que produzem equipamentos nucleares. É esta luta que explica o entusiasmo de certos setores por energia nuclear, e não a ação virtuosa, que seria reduzir as emissões de carbono. (...)"

Goldemberg afirmou no mesmo artigo que "o domínio da tecnologia nuclear por si só não torna o país grande potência nesta área". Também criticou os custos de conclusão de Angra 3.

Em artigo de 4/08/2006, intitulado "Não basta perder o sono com 0 clima", Washington Novaes afirmou que: 
“(...) Por mais que os acontecimentos e a ciência recomendem prudência nas políticas em todo o mundo, diante das evidências das mudanças climáticas em toda parte, que impõem transformações drásticas nas matrizes energéticas - de modo a reduzir a emissão de gases poluentes da atmosfera , as lógicas políticas e financeiras continuam a traçar, para manter o predomínio do petróleo e do carvão mineral como principais fontes de energia, uma rota de fuga em direção a tecnologias temerárias e formatos insustentáveis, como a energia nuclear (que é mais cara, vulnerável por vários ângulos e incapaz de resolver o problema do lixo radiativo).(...)"

A referência à energia nuclear no artigo foi centrada nos aspectos de sua vulnerabilidade e incisiva na questão dos rejeitos radioativos.

No editorial "O fiel da balança ambiental", de 16/01/2006, reflexões sobre o consumo e estilo de vida:

“(...)A questão central, como se sabe, é a dos padrões de consumo de energia, fontes de alimentos e matérias-primas. Mantidos os padrões que caracterizam o estilo de vida do Ocidente desenvolvido, o crescimento colossal da demanda combinada dos 2,5 bilhões de habitantes da China e da Índia representará para o meio ambiente uma carga literalmente insuportável. Desde já provoca alarmantes efeitos em cascata por toda parte, observa o estudo, citando, entre outros, o aumento das pressões sobre as reservas florestais brasileiras. (...)"

A miséria, globalização acelerada e problemas sociais mundiais foram retratados em vários artigos, que funcionam de forma complementar ao conteúco noticioso das editorias. Ainda em 2006, a abordagem sobre mudanças climáticas era tímida, do ponto de vista quantitativo.

Uma discussão que continua atual se refere às eleições. $O$ debate climático continua sendo encarado como questão marginal. Seguem as discussões políticas, mas na prática as medidas nacionais ainda são muito incipientes. Não há iniciativas mais fortes de reduções de emissões e continua a política ambiental pouco agressiva e compromissada com a revolução e revisão de valores que o momento exige. Na seção Espaço Aberto de 22/09/2006, o jornal publicou artigo intitulado "Em qual país é esta eleição", em que Washington Novaes discute o tema ambiental, vinculado às mudanças climáticas, na agenda política brasileira.

“(..) Muitas vezes tem sido citado aqui o pensamento do secretário-geral da ONU, Kofi Annan, segundo quem os problemas que ameaçam a sobrevivência da espécie humana são as mudanças climáticas em curso e a insustentabilidade dos padrões mundiais de produção e consumo. Se é assim, essas questões deveriam estar no centro das discussões sobre 0 futuro do País. Mas não estão. 
Qual é, por exemplo, a estratégia brasileira para enfrentar mudanças climáticas? Não está na pauta. Mas já começamos a sofrer com elas, inclusive em áreas que - estas, sim - geram preocupações: estamos perdendo partes de safras por causa de secas, inviabilizando culturas por causa do aumento da temperatura; estamos tendo custos cada vez mais altos com inundações, deslizamentos de terras, inviabilização de rodovias. (...)"

Merece ressalva que nem todos os eventos climáticos extremos podem ser creditados às mudanças globais do clima, geradas pelo aumento de emissões dos gases de efeito estufa.

No artigo "Biomassas - para sair das platitudes", também de Washington Novaes, publicado em 20/10/2006, na seção Espaço Aberto, foi destacada a importância de se tratar o tema mudanças climáticas de forma mais ampla, com implicações em vários setores. Trata-se de uma discussão importante e reiterada no artigo, a partir de declaração do então secretário-geral da ONU.

“(...) Há poucos dias, Kofi Annan, que está deixando a Secretaria-Geral da ONU, advertiu: 'A ação na área de mudanças climáticas é particularmente urgente, dadas suas profundas implicações em praticamente todos os ângulos do bem-estar humano, desde o emprego e a saúde ao crescimento econômico e à segurança (...) Enquanto não deixarmos de tratar mudanças climáticas com uma preocupação apenas ambiental - e em lugar disso reconhecermos a natureza ampla dessa ameaça -, nossa ação será insuficiente.' O risco, já disse ele, traduz-se em ameaças à sobrevivência da espécie humana.(...)"

No ano de 2006, a revista semanal Veja publicou duas capas sobre o tema, em junho e dezembro, e 11 edições, das 52 anuais, veicularam reportagens sobre mudanças climáticas. Vinte e uma edições continham pelo menos algum texto sobre mudanças climáticas. Foram detectados erros em conceitos técnicos como a definição de efeito estufa e o termo ter sido utilizado inadequadamente como sinônimo de aquecimento global, além de associações aos gases de efeito estufa como gases tóxicos. As fontes dos gases de efeito estufa também não foram explicitadas adequadamente. A cobertura seguiu o tom catastrofista.

A reportagem da edição 1939, de 18/01/2006, "A poluição que vem da mata", abordou a emissão de metano pela vegetação. O efeito estufa foi utilizado como sinônimo de aquecimento global. Os gases de efeito estufa também foram expostos no texto como gases tóxicos e suas fontes foram limitadas e não especificadas. A explicação para o fenômeno efeito estufa também foi inadequada. 
"O metano, assim como o dióxido de carbono, o óxido nitroso e os fluorcarbonetos, gases tóxicos produzidos em sua maior parte pela atividade humana, concentra-se em quantidades cada vez maiores na atmosfera, impedindo que o calor dos raios solares que chegam à Terra se disperse adequadamente. O resultado é o chamado efeito estufa."

$\mathrm{Na}$ reportagem de 8/02/2006, "O ano mais quente", sobre as altas temperaturas de 2005, a mesma referência foi feita aos gases de efeito estufa, chamados de gases tóxicos, "produzidos pela atividade humana, que permanecem na atmosfera e provocam o chamado efeito estufa". Também as emissões que se pretende estabilizar são de dióxido de carbono e não de monóxido de carbono, produzido na queima de combustíveis e que se liga ao oxigênio para formar $\mathrm{O} \mathrm{CO}_{2}$.

"O climatologista David King, consultor ambiental do governo inglês, reconhece que será difícil estabilizar a concentração de monóxido de carbono na atmosfera daqui a dez anos, como seria desejável."

As ameaças do aquecimento foram mostradas de forma esquemática, com imagens-símbolo da temática e com tratamento visual de alta qualidade, conforme retrata a FIG. 4.1.

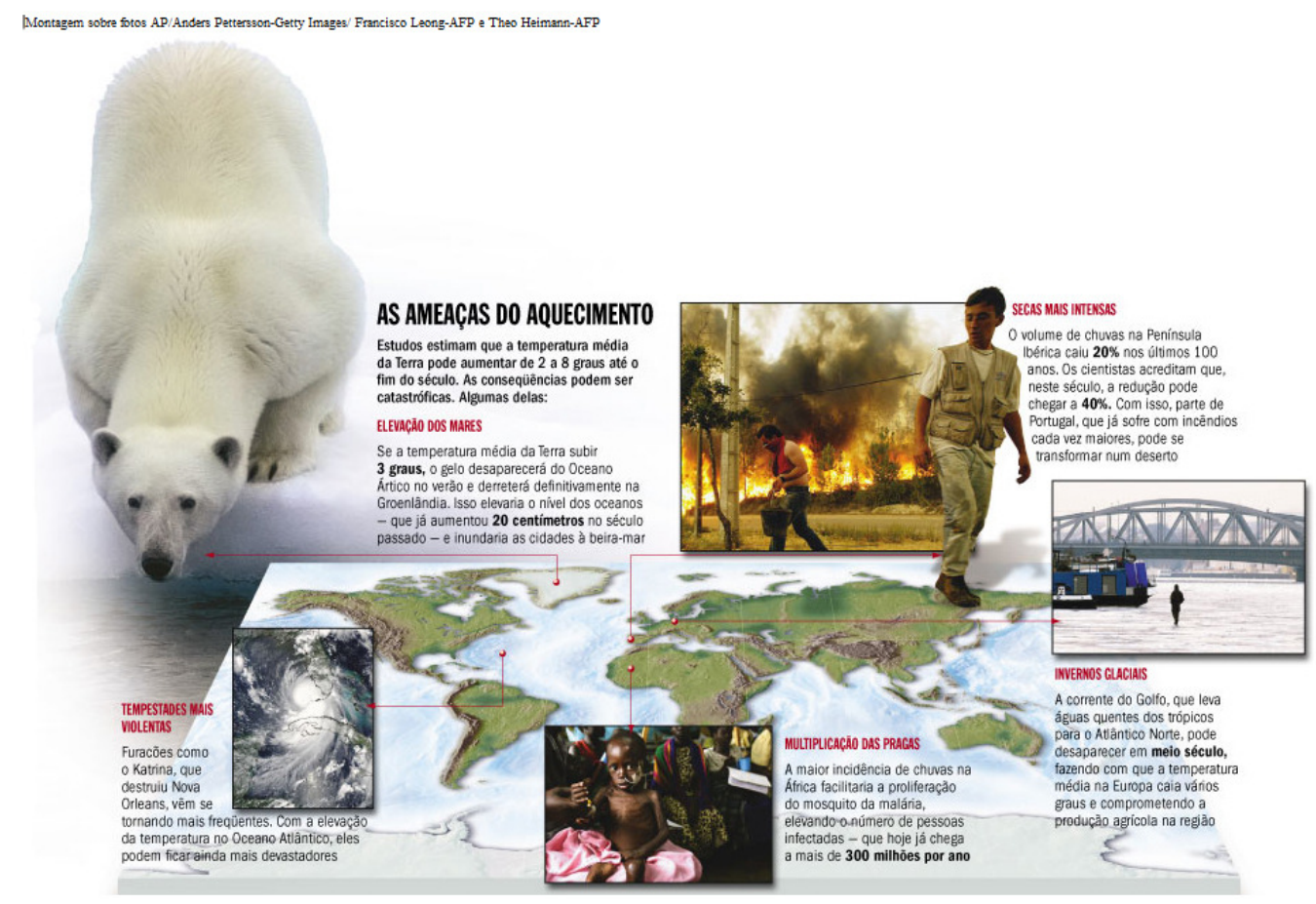

FIGURA 4.1 - Página de reportagem da revista Veja de 08/02/2006

Fonte - http://veja.abril.com.br/080206/popup_clima.html 
Em artigo de Stephen Kanitz, de 15/02/2006, seção Ponto de Vista, apresentou-se uma visão para a questão ambiental relegada a segundo plano:

"Criamos uma economia mundial que incentiva produtos descartáveis, criamos uma sociedade consumista, predadora e destruidora, tudo isso para maximizar o PIB. O endeusamento do PIB e do pleno emprego como meta política é a causa do aquecimento global, da destruição da ecologia, do desmatamento florestal, da poluição global e do crescimento exponencial do lixo."

Em "Cenários para a Amazônia", de 29/03/2006, foi apresentado um estudo desenvolvido por pesquisadores brasileiros e norte-americanos para a região, com dois cenários possíveis. Alguns dos termos utilizados, seguindo a linha de estudos desenvolvidos para a região: previsões sombrias, panorama alarmante, devastação, destruição.

$\mathrm{Na}$ edição 3/05/2006, a reportagem "Uma mina de ouro no Ártico", discorreu sobre um efeito inusitado do aquecimento global: a exploração econômica no Ártico. Ao mesmo tempo em que ameaça espécies, abriria possibilidades econômicas. Dois trechos elucidam o tom da reportagem:

"O aquecimento global está produzindo efeitos devastadores no Ártico. No último verão no Hemisfério Norte, a calota de gelo foi reduzida ao menor tamanho já registrado. A ponto de, pela primeira vez, cientistas russos navegarem até o Pólo Norte sem precisar abrir caminho com navios quebragelos. Isso ocorre porque a temperatura na região polar aumenta em média duas vezes mais que no resto do planeta. O fenômeno tem efeitos ecológicos danosos - toda uma fauna adaptada ao frio rigoroso, que inclui ursos-polares, baleias, focas e morsas, está ameaçada de extinção -, mas, paradoxalmente, está provocando uma espécie de corrida do ouro ao Círculo Polar. Isso ocorre por dois motivos principais: o derretimento do gelo vai permitir a exploração das reservas de petróleo e gás natural no Oceano Ártico e abrir novas e mais curtas rotas de navegação.

(...)É verdade que com o degelo aumenta o perigo dos icebergs, mas, em compensação, os campos petrolíferos no Ártico não serão ameaçados pela instabilidade política e pelos homens-bomba do Oriente Médio."

Uma ilustração com a seguinte legenda é apresentada:

"Eu sou um otimista. Tenho toda a certeza de que o aquecimento global vai ser anulado pelo inverno nuclear."

Em 21/06/2006, a capa de Veja, demonstrada na FIG. 4.2, trouxe a figura do urso polar e a edição traz uma série de reportagens a partir de discurso 
catastrófico ("Os sinais do Apocalipse", "Já começou a catástrofe"), contendo narrativas dessa natureza:

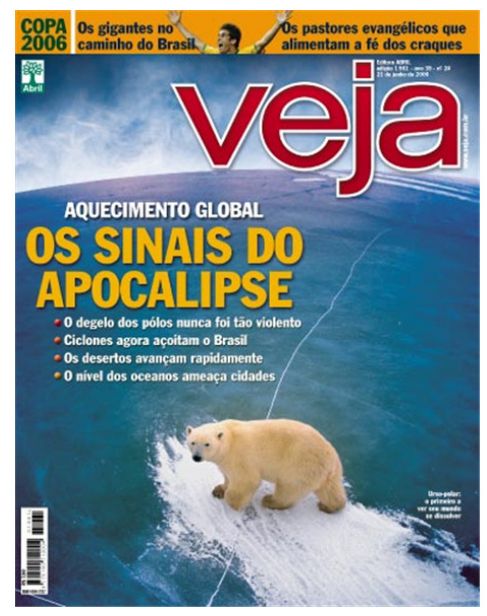

FIGURA 4.2 - Capa da revista Veja de 21/06/2006

Fonte - http://veja.abril.com.br/idade/exclusivo/210606/capa.html

"Já começou a catástrofe causada pelo aquecimento global, que se esperava para daqui a trinta ou quarenta anos. A ciência não sabe como reverter seus efeitos. A saída para a geração que quase destruiu a espaçonave Terra é adaptar-se a furacões, secas, inundações e incêndios florestais."

Alguns trechos desta cobertura:

"O aquecimento global fez diminuir em $20 \%$ a calota polar ártica nas últimas três décadas, reduzindo o território de caça dos ursos-polares. Muitos deles ficaram sem alimento. A mudança radical de seu habitat provocada pelo homem está custando caro aos ursos. Recentemente, no Mar de Beaufort, no Alasca, pesquisadores americanos que há 24 anos estudam a região identificaram um caso inédito de canibalismo na espécie: duas fêmeas, um macho jovem e um filhote foram atacados e comidos por um grupo de machos. Estimativas apontam que os ursos-polares podem desaparecer em vinte anos."

"Até os mais céticos comungam agora da idéia apavorante de que a crise ambiental é real e seus efeitos, imediatos. O que divide os especialistas não é mais se o aquecimento global se abaterá sobre a natureza daqui a vinte ou trinta anos, mas como se pode escapar da armadilha que criamos para nós mesmos..."

"Vários países estão reconsiderando a energia nuclear, que hoje provê 16\% do total. Só a China quer construir 32 usinas até 2020."

"Campanhas de ONGs e ambientalistas propõem que cada pessoa faça sua parte, como deixar o carro na garagem alguns dias por semana. São atitudes louváveis, mas de pouco efeito prático. "São necessárias grandes estratégias 
e investimentos pesados para transformar o modo como o mundo viveu nos últimos vinte anos", define o americano John Reilly, do MIT."

Algumas notas sobre ferramenta para medir o quanto cada pessoa contribui para o efeito estufa e cartas de leitores comentando reportagens sobre o tema são encontradas no levantamento de textos da revista referentes ao assunto.

Na edição 1967, de 2/08/2006, a reportagem "Será que já começou?" abordou a elevação de temperaturas em todo o mundo que podem estar relacionadas ao fenômeno do aquecimento global. Para balizar a discussão, ouviram um especialista para explicar a situação.

“(...)Diz o meteorologista Carlos Nobre, do Instituto Nacional de Pesquisas Espaciais: "Ainda não conseguimos determinar com precisão por que os bloqueios de ar frio estão ocorrendo com freqüência maior. Mas é grande a probabilidade de que por trás deles esteja o aquecimento global provocado pelo homem"."

Mas, no decorrer do texto, os conceitos relacionados às mudanças climáticas são expostos de forma equivocada. Gases de efeito estufa não são mencionados, e em seu lugar os gases tóxicos são culpados novamente

"O aquecimento global, causado pelos gases tóxicos produzidos por fábricas, automóveis e termelétricas, não é mais uma vaga ameaça ao futuro do planeta. Ele se tornou realidade. Está por trás dos furacões cada vez mais devastadores, das inundações, do derretimento das calotas polares e do avanço das áreas desérticas".

No site da revista, sob o título "Aquecimento global em profundidade", foi publicado material específico sobre o tema, animações, imagens, textos e outros conteúdos exclusivos, com divulgação na edição impressa de 13/09/2006. Os textos tratam da origem do fenômeno e seus efeitos, além da busca da ciência por soluções eficazes.

$\mathrm{Na}$ edição 1975, de 27/09/2006, na reportagem "A agonia dos oceanos", alguns erros conceituais como mencionar $0 \mathrm{CO}_{2}$ como gás venenoso. Porém apresenta vários pontos positivos, como mostrar situações críticas nos oceanos, de degradação ambiental. Os exemplos e informações divulgadas tornaram o material bastante interessante e atrativo.

Na edição 1979, de 25/10/2006, a revista publicou uma entrevista com James Lovelock, cientista que desenvolveu a teoria de Gaia, de que a Terra é um 
organismo vivo que se auto-regula. O título da entrevista, A vingança de Gaia, é o mesmo do livro em que o autor aborda o rompimento do equilíbrio natural do planeta, por conta das mudanças climáticas. Alguns trechos que sintetizam o conteúdo da reportagem:

"Pelas minhas estimativas, a situação se tornará insuportável antes mesmo da metade do século, lá pelo ano 2040."

"É um erro acreditar que podemos evitar o fenômeno apenas reduzindo a queima de combustíveis fósseis. O maior vilão do aquecimento é o uso de uma grande porção do planeta para produzir comida. As áreas de cultivo e de criação de gado ocupam o lugar da cobertura florestal que antes tinha a tarefa de regular o clima, mantendo a Terra em uma temperatura confortável. Essa substituição serviu para alimentar o crescimento populacional. Se houvesse 1 bilhão de pessoas no mundo, e não 6 bilhões, como temos hoje, a situação seria outra. Agora não há mais volta."

"Há previsões mais confiáveis de um aumento de até 6 graus até o fim do século. Essa vai ser a média global. Em algumas regiões, o aumento de temperatura será ainda maior."

"Não é só uma questão de aumento de temperatura. Com a mudança climática, será impossível cultivar alimentos ou criar animais de abate, porque simplesmente não haverá chuva ou água para a irrigação."

"A única opção é substituir as fontes de energia mais comuns por usinas nucleares, mais limpas do que hidrelétricas ou termoelétricas. O gás carbônico vai nos matar se não fizermos nada a respeito. As pessoas têm medo do lixo atômico, mas isso é um mito. A quantidade de resíduos produzida pelas usinas nucleares é irrisória e não causa grandes problemas ambientais. A energia nuclear, no entanto, não é uma solução, e sim uma medida para ganharmos tempo. A roda do aquecimento global já está em movimento, e não há como freá-la."

"Cem gramas de urânio equivalem a 200 toneladas de carvão, em termos de energia gerada. Com 100 gramas de urânio não se produzem mais do que 100 gramas de lixo atômico, enquanto a poluição emitida pela queima de 200 toneladas de carvão é de 600 toneladas de dióxido de carbono. Entre 100 gramas e 600 toneladas de resíduos, é óbvio que o carbono é um problema maior."

"A ciência e a tecnologia passaram a ser rejeitadas e classificadas como ruins para o ambiente. E o que acontece com as plantas geneticamente modificadas e com a energia atômica. Vivemos em uma sociedade hipocondríaca."

$\mathrm{Na}$ entrevista, Lovelock também registrou a crítica de que os cientistas estudam o aquecimento global de maneira fragmentada e acabam com dificuldades em desenvolver uma visão geral do fenômeno. 
Em outra entrevista publicada na edição 1981, de 8/11/2006, intitulada "O alerta global", Nicholas Stern mostrou que o prejuízo com o aquecimento do planeta era muito maior do que se imagina. Novamente se percebe a confusão na definição do efeito estufa, explicado equivocadamente como o acúmulo de gases poluentes na atmosfera. O equívoco persiste ao longo de praticamente todo o material produzido em 2006. O trecho inicial da reportagem é transcrito a seguir:

"O inglês Nicholas Stern, chefe do serviço econômico do governo de seu país, recebeu há dezesseis meses uma tarefa colossal: medir o impacto do aquecimento global na economia mundial. Ex-economista-chefe do Banco Mundial e diplomado pelas universidades de Cambridge e de Oxford, Stern lançou mão de modernos modelos matemáticos e econômicos na tentativa pioneira de estimar os prejuízos decorrentes do chamado efeito estufa - o acúmulo de gases poluentes na atmosfera, que está fazendo a temperatura da Terra subir assustadoramente."

Em "Para abraçar a causa verde", na edição 1983, de 22/11/2006, novamente gases de efeito estufa são chamados de fortes poluentes. A reportagem aborda uma campanha voltada a reduzir as emissões per capita de gases de efeito estufa, a partir de pequenas alterações na rotina. Um quadro mostra como e quanto é possível ajudar. Em outro, quantas árvores plantar para pagar a dívida. Para o leitor, fica a ideia de compensação. Poluir para depois ter atitudes para minorar o dano. Um modismo que traz falsa impressão de redenção.

Em "Salvar o planeta dá lucro", de 06/12/2006, o mercado de créditos de carbono, a explicação sobre seu funcionamento e a apresentação do Brasil como vice-líder no registro de projetos dessa natureza. Uma imagem publicada refletiu dificuldades para os povos da África. Impactante, a foto tinha a seguinte legenda:

"Mulheres da tribo masai buscam água na Tanzânia: secas mais freqüentes na África são reflexo das mudanças climáticas"

Na edição de 27/12/2006, a redução da neve nas estações de esqui foi tema de reportagem. O estudo foi divulgado pela OCDE, que previu que o fenômeno tende a piorar. Os quadros são constantes na cobertura. Explicitam de forma esquemática algum aspecto da reportagem.

Em 30/12/2006, uma edição especial chegou às bancas. Alerta global era o título de capa que despertava para o problema das mudanças climáticas. Trazia uma síntese da situação e apresentava soluções para enfrentá-la, de acordo com o editorial. Em doze páginas, mostrou sete projetos radicais para 
salvar o planeta e, nos quadros que acompanhavam as fotos, as principais consequências das mudanças climáticas. Como imprecisão, pode ser citada a referência ao $\mathrm{CO}_{2}$ como o gás causador do efeito estufa, como se ele fosse o único.

Ao mencionar a opção pela energia nuclear para ajudar a diminuir as emissões dos gases de efeito estufa, enfatizou o texto que ainda não se conseguiu uma forma totalmente segura de descartar o lixo radioativo, mas diante da crise relacionada ao aquecimento global cada vez mais cientistas acham melhor "optar pelo lixo nuclear e pesquisar formas de processar seus resíduos."

Na revista Época em 2006 foram seis edições contendo reportagens sobre o tema mudanças climáticas. A cobertura também apresentou erros conceituais, em definições básicas relacionadas ao sistema climático. Na edição 405, de 20/02/2006, a reportagem "Vem aí uma era glacial?" mostrava exemplos de mudança drástica do planeta e afirmava:

"Por paradoxal que pareça, o aquecimento global pode, segundo estudos, desencadear uma nova era glacial em algumas regiões".

Também fez referência ao degelo na Groenlândia, como um problema não só para os esquimós e ursos-polares, mas um fator de contribuição para elevação do nível dos mares, ocasionando inundação de cidades.

A edição 412, de 10/04/2006, "O aquecimento global é tão grave?" trouxe argumentos dos chamados cientistas céticos do aquecimento, questionando o pânico criado em torno do assunto.

$\mathrm{Na}$ edição 418, a discussão sobre o custo de se evitar as mudanças climáticas, afirmando que as empresas responsáveis pela emissão de gases poluentes começaram a despertar para a questão, por terem descoberto o "ótimo negócio".

$\mathrm{Na}$ edição 437, de 02/10/2006, uma entrevista com Al Gore apresentando sua causa: mudar a mentalidade do povo americano. Segundo ele, "políticos, ecologistas ou não, só serão capazes de fazer mais ou menos dependendo de como as pessoas se sentem em relação à crise".

$\mathrm{Na}$ edição 439, de 16/10/2006, a capa estampava o título "Pense verde". Os textos traziam muitas referências a trabalhos de instituições científicas e dados sobre problemas como desmatamento, trânsito, falta de água, lixo, ou seja, reuniu dados de vários campos importantes para a discussão da degradação 
ambiental em que se encontra o planeta. Apesar de algumas incorreções como o fato de o efeito estufa ser apontado como "a maior ameaça enfrentada por nossa civilização" ou a explicação incorreta sobre a existência do fenômeno, "emissão de poluentes, como o gás carbônico, que alteram a atmosfera terrestre", vários pontos positivos podem ser destacados. Um deles é a abordagem das leis ambientais como modernas, porém difícil de implementar, especialmente em regiões "onde as disputas são decididas a bala". Ou seja, além de impor medidas restritivas, é preciso fiscalizar, fazer cumprir, se não de pouco adianta a legislação. No restante dos textos, o alerta feito pelos cientistas e o problema do convencimento de políticos e economistas sobre a dimensão da crise. Em alguma medida, um pouco de exagero, como o fato de as descobertas deixarem os próprios pesquisadores "apavorados". Porém a tônica era de que o homem se sairá bem deste "maior desafio do século". A apresentação do metano como gás de efeito estufa e a discussão sobre o percentual da população das cidades e o que isso representa foram outros pontos positivos.

$\mathrm{Na}$ edição 442, de 06/11/2006, discussão sobre o crescimento da China e da Índia, e sobre o desafio de manter o crescimento adotando tecnologias não poluentes. A energia nuclear foi citada no programa energético desses países, mas com a ressalva de que a fonte representa baixo percentual de contribuição. Outras opções foram mencionadas, confrontando a demanda energética com a insustentabilidade do padrão almejado.

\subsubsection{Ano de 2007}

Basicamente a cobertura dos jornais diários no ano de 2007 consistiu em explicitar os relatórios do IPCC. O tom de catástrofe, devastação ficou marcado na cobertura de Veja, que buscou impactar o leitor. É desta publicação uma das capas de maior impacto ou mais chamativas para o problema, mostrando ursos polares em seu habitat, ameaçado pelas mudanças climáticas.

No ano de 2007, no jornal Folha de S. Paulo, foram analisadas 169 reportagens da editoria Ciência, 19 na editoria Opinião, 17 na editoria Mundo, 7 da editoria Mais, 7 na editoria Brasil, 7 na editoria Dinheiro, 4 da editoria Equilíbrio, 2 na editoria Informática, 3 na Revista da Folha (revista dominical), 2 na Folhinha (destinada ao público infantil), 2 na Folhateen e um para cada um dos 
seguintes cadernos: Turismo, Veículos, Negócios, Revista Morar (suplemento). Também em 2007 foi editado um Caderno Especial. A abordagem na editoria Ciência seguiu os temas demonstrados na TAB. 4.3.

TABELA 4.3 -Textos sobre mudanças climáticas da editoria Ciência da FSP em 2007

\begin{tabular}{lc}
\hline Tema & Incidência \\
\hline Políticas envolvendo mudanças climáticas & $33 \%$ \\
\hline Pesquisas sobre mudanças climáticas & $28 \%$ \\
\hline Enfrentamento das mudanças climáticas em geral & $22 \%$ \\
\hline Consequências ou efeitos das mudanças climáticas & $11 \%$ \\
\hline Combate ao desmatamento & $2 \%$ \\
\hline Outros & $4 \%$ \\
\hline
\end{tabular}

Fonte - Elaborada pela autora

$\mathrm{Na}$ editoria Ciência, a abordagem de $33 \%$ dos textos foi predominantemente política e $28 \%$ para pesquisas relacionadas ao tema mudanças climáticas desenvolvidas em instituições científicas. Combate às mudanças climáticas foi tema predominante em outros 37 textos, totalizando $22 \%$. Conseqüências do aquecimento global e/ou seus efeitos foi mensurado como abordagem principal em outros 19 textos, totalizando 11\%. Desmatamento e combate ao desmatamento foram a abordagem principal em 3 textos (1,8\%). Inventário de emissões foi o enfoque principal de 2 textos (1,2\%). Marketing com a causa ambiental, denúncia, projeções (panorama energético) e MDL foram a abordagem principal de um texto para cada um dos temas. Um texto da editoria Ciência teve como abordagem principal a dúvida a respeito das mudanças climáticas.

No início do ano a cobertura apresentou tom de revelação, como auxiliando o leitor a acessar item a item o que as previsões climáticas vaticinavam. Também um texto contendo denúncia de que a empresa Exxon financiaria a negação do efeito estufa foi publicada nesse período (edição de 5/01/2007, com o título "Exxon financia negação do efeito estufa, acusa grupo"). As consequências das mudanças climáticas, medidas de combate (especialmente na União Europeia) e discussões no campo político também deram a tônica do primeiro trimestre do ano. Com a divulgação do quarto relatório do IPCC, nos meses de fevereiro, abril e maio, a cobertura voltou-se para os dias de reunião, os 
termos utilizados no documento, as negociações políticas e discussões. Também o relatório síntese sobre os três grupos de trabalho (bases das ciências físicas, adaptação e mitigação, impactos econômicos e vulnerabilidade) foi divulgado em novembro. Em dezembro, houve a cobertura da COP-13, de Bali, Indonésia.

A falta de água potável, elevação do nível do mar, ondas de calor, derretimento de geleiras, aumento da temperatura, savanização da Amazônia e outras conseqüências descritas nos estudos sobre mudanças climáticas figuram em títulos explicativos e especialmente sugestivos - "O inferno é aqui", "Assando a Mata Atlântica", "Baixada submersa", "Abominável mundo novo", "Nuvens negras" -, adotados em sub-retrancas e quadros de reportagens, que funcionam como um complemento, material de apoio para o conteúdo principal ou até mesmo um resumo, objetivando trazer melhor entendimento do que foi publicado. Infográficos e glossários ajudam a entender expressões e termos de estudos acadêmicos. Um exemplo é "Pequeno Dicionário de Balinês", que tem como entretítulo "O que você precisa saber para entender as negociações sobre o clima”. Constam ainda reproduções de conteúdos veiculados por agências internacionais e matérias produzidas a partir de entrevistas com especialistas nacionais, seja no campo técnico-científico (como Carlos Nobre, José Goldemberg, Luís Pingelli Rosa) ou no campo político (Marina Silva - então ministra do meio ambiente do Brasil, Yvo de Boer - secretário-executivo da UNFCCC).

De abril a junho, foi publicado extensivo material sobre combate à crise climática, especialmente no campo político internacional, mas também surgiram alguns exemplos sobre projetos nacionais para combater emissão de gases de efeito estufa, como projetos patenteados por dois grupos de pesquisa para captura e queima de metano, explicitados na reportagem "Usina pode ganhar com gás emitido em represas”, de 26/06/2007, publicada na editoria de Ciência.

No terceiro e quarto trimestre do ano, as metas de redução de gases de efeito estufa, mobilização para negociações internacionais e o papel da ONU nas discussões figuram nas pautas predominantemente sobre política e ambiente. No texto "Circo do fim do mundo acaba entre acusações e lágrimas", de 15/12/2007, assinada pelo então editor Claudio Angelo, uma impressão muito intimista do que foi a conferência, apresentando uma narrativa bastante eficaz em seu propósito de aproximar o leitor do ambiente da conferência: 
"É difícil transmitir a tensão que se viu e sentiu em Bali na última semana das negociações do Mapa do Caminho. A melhor expressão desse sentimento talvez tenha sido a do secretário-executivo da Convenção do Clima, o holandês Yvo de Boer: diante do impasse na plenária, exausto após uma reunião que fora interrompida às $3 h 30$ da manhã e reiniciada às $8 h$, ele pôs a mão no rosto, chorou e saiu da sala.

(...)

Nesse momento, Ban Ki-moon interveio na plenária. Daí em diante, seguiramse trocas de acusações, com os chineses culpando De Boer (que chorou) e os sul-africanos acusando os EUA de jogo sujo. Diplomacia à flor da pele."

Com a utilização de termos explicativos para o Protocolo de Quioto como "a iniciativa da ONU contra o efeito estufa" (em editorial de 1/06/2007, intitulado "Ataque preventivo"), a mensagem persistente é de que tal efeito é prejudicial.

No editorial "Era da certeza", de 4/02/2007, uma explicação para o fenômeno efeito estufa, porém apenas dois gases de efeito estufa são mencionados. Também não há menção ao efeito benéfico desses gases para a atmosfera terrestre, possibilitando condição de vida:

“(...) Veículos, indústrias, termelétricas não-nucleares, desmatamento e até agropecuária lançam na atmosfera os chamados gases do efeito estufa, como dióxido de carbono $\left(\mathrm{CO}_{2}\right)$ e metano $\left(\mathrm{CH}_{4}\right)$. Tais substâncias dificultam a irradiação, de volta para o espaço, do calor da Terra aquecida pelo Sol. Como sua concentração no ar cresce desde a época pré-industrial, o efeito estufa se agrava, e o clima extrapola seus limites naturais de variação.(...)"

Novamente, em editorial de 14/01/2007, intitulado "Por um clima melhor", o fenômeno efeito estufa é explicitado de forma equivocada - seria, de acordo com o texto, o aquecimento anormal da atmosfera.

“(...) Arrancando no que já se chama de revolução pós-industrial, a Comissão Européia comunicou o compromisso voluntário de cortar, até 2020, no mínimo $20 \%$ sobre os níveis de 1990 as suas emissões de gases que provocam o efeito estufa, o aquecimento anormal da atmosfera.(...)"

Outro exemplo de uso incorreto do termo efeito estufa é encontrado no entretítulo de reportagem do caderno de Ciência de 27/06/2007 - "IBGE registra aumento no nível do mar no RJ e em SC".

"Elevação em Macaé, no Estado do Rio, sugere que cidade pode estar afundando

Medições feitas de 2001 a 2006 demonstram que em Imbituba, SC, nível médio do oceano subiu $1 \mathrm{~cm}$; efeito estufa é possível culpado" 
Na reportagem "China passa os EUA e se torna o maior poluidor", de 21/06/2007, editoria Ciência, houve menção equivocada ao "combate ao efeito estufa".

Na editoria Mundo, o uso do termo efeito estufa de forma inadequada pode ser observado em reportagem de 21/12/2007, com o título "Bush barra lei estadual para combate a efeito estufa". Trata-se de lei que limita emissões veiculares.

Marcelo Leite assina o texto "Aquecimento é 'inequívoco', diz painel”, publicado na editoria Ciência em 3/02/2007, exemplo de trabalho de qualidade, do qual se reproduz um trecho:

“(...) Nessas negociações multilaterais, a escolha das palavras tem muito peso. No relatório anterior, de 2001, o IPCC dizia que a contribuição humana era apenas "provável". No código climático-político, isso quer dizer "mais de $66 \%$ de certeza.

Já se sabia que o documento aprovado ontem iria vitaminar o vocabulário sobre certeza, pondo mais pressão sobre governos para que enfrentem o problema. Por isso o relatório era tão aguardado. Mas ele também alterou significativamente as projeções de 2001.(...)"

Na mesma reportagem, no entretítulo "O mais aguardado prognóstico da saúde do clima no planeta encerra de vez o debate sobre se os humanos têm ou não culpa pelo efeito estufa" foi cometida a mesma incorreção, ao se utilizar efeito estufa como sinônimo para aquecimento global. A expressão "encerra de vez" também não é recomendável, já que a incerteza é própria do processo de produção do conhecimento científico.

$\mathrm{Na}$ análise do material produzido pela publicação em 2007, também é perceptível a ocorrência de erros em entretítulos e legendas, como por exemplo a legenda de foto publicada em 24/03/2007, na editoria Ciência:

"Surfista observa ressaca no Leblon, evento que ficará mais freqüente com o aquecimento global"

Em nenhum momento da reportagem ficou evidente que as ressacas ficariam mais freqüentes. O tema da reportagem são as obras de engenharia como apoio à adaptação às mudanças climáticas na cidade do Rio de Janeiro, um projeto da Coppe.

$\mathrm{Na}$ reportagem "País ignora seu novo clima, diz cientista", de 8/03/2007, editoria Ciência, foi mencionado o atraso brasileiro nas pesquisas sobre o tema: 
"O Brasil está dez anos atrasado na realização de estudos científicos para investigar os impactos que a mudança climática já estão causando e continuarão a causar no país, e perde até para Trinidad e Tobago nesse tipo de estudo. A avaliação é do climatologista Carlos Afonso Nobre, pesquisador do INPE. (...)"

Faltaram matérias sobre uso de fontes energéticas alternativas no país e no mundo, matriz energética e plano energético brasileiro tendo em vista o cenário com a componente mudanças climáticas. Porém o volume de informações no ano originado pela divulgação dos relatórios e a quantidade de estudos fez com que a seleção de temas, apuração e edição de conteúdos fosse um trabalho minucioso.

Quanto aos editoriais, abordam os alertas da comunidade científica e as discussões políticas que lançam a questão climática como prioridade, porém sem posicionamento decisivo por parte do governo brasileiro, como uma espécie de jogo em que se está perdendo ou avançando muito pouco. Em um dos títulos, o xadrez é a referência utilizada. A articulação política no cenário mundial e a posição brasileira, consubstanciada em expressões como "o mutismo de sempre sobre a mudança climática global”, e referência a omissões brasileiras em não assumir metas de redução figuraram em outros textos.

Os dados antigos do Brasil sobre inventário de mudanças do clima também mereceram destaque, pois o único inventário produzido até então continha dados de 1994 (permanece o mesmo até novembro de 2010, tendo passado por consulta pública o esboço da segunda comunicação nacional). Uma organização social em parceria com o MCT preparava dados para o segundo inventário, em 2007, que no entanto não contemplava as emissões de GEE oriundas de desmatamento. Dados desse estudo, sobre o qual se publicou editorial intitulado "Herança poluída", na edição de 26/11/2007, mostravam que o país "segue na contramão, sem dar a devida atenção a eficiência energética, energias alternativas e transporte ferroviário."

As negociações de Bali "aquém do necessário" (título de outro editorial, de 14/12/2007) foram assunto de três editoriais no último trimestre do ano.

Em cadernos como Equilíbrio há bons exemplos de reportagens que abordam o tema mudanças climáticas, como a reportagem "Vida sustentável", publicada em 15/02/2007: 
"O planeta está esquentando, e o risco de catástrofes naturais, aumentando. E o que você tem a ver com isso? Tudo. A queima de combustíveis fósseis e a produção desenfreada de lixo - duas das principais causas do aquecimento global - estão diretamente relacionadas ao estilo de vida urbano, consumidor e predador da natureza que os humanos vêm adotando de modo cada vez mais acelerado.

Dá para mudar? Dá. Até mesmo na vida cotidiana, vivendo em cidade grande, morando em apartamento, trabalhando em prédio fechado com arcondicionado e tendo carro.

A Folha ouviu especialistas e reuniu dicas simples para cuidar melhor da Terra e reduzir o impacto da nossa passagem por aqui. Para construir um planeta menos arriscado onde viverão seus netos e os netos dos seus netos. Para ser sustentável no dia-a-dia.

É claro que não é tudo. Há ameaças maiores. Somos moradores do país que concentra um terço das florestas mundiais e que ainda as desmata. Temos a maior biodiversidade do planeta e poucos governantes atentos a isso.(...)"

$\mathrm{Na}$ editoria Mundo, a cobertura se concentrou mais nos meses de junho e outubro, com quatro reportagens em cada um desses meses. No primeiro caso, deveu-se à reunião do G8 e, em outubro, à outorga do Nobel ao IPCC e ao ex-vice-presidente norte-americano Al Gore.

Na mesma editoria, o texto de 24/11/2007 "Clima ameaça aliado de Bush na Austrália" mostrou como o aquecimento global seria fator determinante numa eleição majoritária de um país rico. Os entretítulos explicavam a matéria:

"Seca de três anos aguça preocupação ambiental e pode encerrar governo do premiê John Howard, há 11 anos no poder.

Líder conservador enfrenta diplomata 18 anos mais novo, que defende retirada do país do Iraque e adesão ao Protocolo de Kyoto".

No caderno Mais, publicado aos domingos, textos especiais e trabalhados de forma distinta da cobertura diária ajudam a entender com estilo mais livre o tema. As histórias fogem do conteúdo diário imposto pelos eventos que ameaçam burocratizar a cobertura, que se torna praticamente obrigatória e corre o risco de padronização nos diferentes veículos. Um exemplo de história diferenciada é o texto "Aquecimento ilhado", de 16/09/2007, assinado por Eduardo Geraque, mostrando o plano de São Tomé e Príncipe contra mudanças do clima, elaborado a partir de consultas públicas. Um trecho da reportagem é transcrito:

“(...) Todo o plano, feito em dois anos, partiu de informações obtidas com a sociedade.

'Foram inquiridas mulheres e homens das camadas mais desfavorecidas do país, tais como agricultores, pescadores (que fornecem $70 \%$ da proteína consumida no país), habitantes das zonas rurais longe das zonas urbanas, assim como habitantes de bairros degradados', diz o texto da metodologia 
do plano, ao qual a Folha teve acesso. Empresas, gestores públicos e ONGs também foram entrevistadas.

Uma lista de 16 problemas foi colocada para os habitantes da zona costeira. O aumento do nível do mar, a erosão costeira e a diminuição das chuvas (o aquecimento poderá também causar secas) causam preocupação em 100\% dos entrevistados.(...)"

$\mathrm{Na}$ editoria Brasil, a publicação de textos em apenas sete edições talvez sirva como indicador de como a crise climática não havia sido incorporada à agenda nacional. E ainda em 2010 a situação não se alterou de forma significativa. Possivelmente se reflete em números de matérias jornalísticas na editoria sobre política nacional, que atualmente se chama Poder, após a reforma editorial da Folha de S. Paulo, ocorrida maio de 2010.

A segunda comunicação nacional do MCT sobre emissões de gases de efeito estufa ainda não foi finalizada, tendo passado por consulta pública os relatórios de referência que compõem o documento. Os dados do país sobre suas emissões estão dispersos e a metodologia de cálculo e padrões de intercomparações para os diferentes setores são questões importantes a se tratar. Ainda está situada principalmente no nível do discurso a questão climática.

Em reportagem de 28/11/2007, "Países pobres vão sofrer mais com clima; ricos terão de ajudar, diz ONU", o detalhe de infográfico enriquece o conteúdo, trazendo um mapa sobre a distribuição do desenvolvimento humano e um quadro com as emissões de $\mathrm{CO}_{2}$.

Em Informática, a utilização do termo aquecimento global na ficção e o tema influenciando as configurações de monitores de computador pautaram duas reportagens. Parece uma subutilização do assunto. Ainda confinado à editoria Ciência, o tema mudanças climáticas poderia chegar ao caderno apresentando abordagem mais voltada ao público jovem e ávido por inovações tecnológicas.

$\mathrm{Na}$ Folhinha, suplemento voltado ao público infanto-juvenil e veiculado aos sábados, apenas duas edições ao longo de 2007 trataram do tema, que esteve na pauta de discussões ao longo de todo o ano, acalorado pela divulgação dos relatórios do IPCC e pela realização da COP em Bali. Sob os títulos "O que acontece com o planeta? Á água vai acabar? O que dá para fazer" e "Matemática do ambiente" foram preparados textos diferenciados e as dúvidas de pequenos leitores foram respondidas por especialistas. Embora os exemplos sejam 
positivos, o tema poderia ter sido melhor explorado e em maior número de edições.

Sobre energia nuclear, reportagens da Folha em 2007 citaram:

“(...) O relatório é neutro quanto à utilização de energia nuclear.(...)"

(UE reduzirá emissões em 20\% até 2020, Ciência, 11/01/2007)

“(...) A proposta da UE, presidida pela chanceler alemã Angela Merkel, menciona a importância da energia nuclear, apesar de não classificá-la como renovável. Esse reconhecimento é uma vitória do presidente francês, Jacques Chirac. Ele liderou a oposição a metas para energia renovável porque mais de $70 \%$ da eletricidade francesa é de origem nuclear.(...)"

(Cúpula da UE adota meta de renováveis, Ciência, 10/03/2007)

“(..) Apesar de reclamações de alguns países, a energia nuclear aparece, pela primeira vez em um relatório do IPCC, como uma opção de mitigação. O problema dela, dizem os críticos, é o lixo tóxico que é gerado".

(Crise do clima precede guinada cultural, Ciência, 6/05/2007)

“(...) A boa notícia é que as soluções estão ao alcance da mão. As diversas opções incluem carros e eletrodomésticos econômicos, o uso de biocombustíveis, a energia nuclear e a redução do desmatamento. O pacote todo pode cortar até $63 \%$ das emissões a um custo razoável (até US\$100 por tonelada de $\mathrm{CO} 2$ abatida). A custo zero, é possível cortar 7 bilhões de toneladas (quase o que a humanidade emite por ano hoje).

No Brasil, a ministra do Meio Ambiente, Marina Silva, disse que quer terminar o plano nacional de enfrentamento da crise do clima em 90 dias.

'Já há várias ações em curso. Não vamos começar do zero.'

Já o ministro Sérgio Rezende (Ciência e Tecnologia) destacou a menção que o IPCC fez à energia nuclear como potencial 'limpo'. 'A resistência a ela vem de alguns ambientalistas pouco esclarecidos', disse."

(IPCC mostra caminho para curar o clima, Ciência, 05/05/2007)

“(...)Um dos momentos de tensão aconteceu na madrugada de sexta-feira, quando se discutiu o papel da energia nuclear. "Foi o maior pau", disse Thelma Krug, da delegação brasileira. No final, a menção à energia nuclear como tecnologia limpa foi mantida, mas junto de objeções dos opositores." (Discussão política entre países foi limpa, dizem ambientalistas, Ciência, 05/05/2007)

"SUSTENTABILIDADE: conceito associado ao desenvolvimento sustentável, envolve a utilização racional dos recursos naturais a longo prazo. Propõe a substituição de combustíveis fósseis e energia nuclear por fontes renováveis, como energia solar ou eólica. No campo social, significa melhor distribuição de renda, universalização do saneamento básico e do acesso à informação, à saúde, à educação e à participação coletiva nas decisões." (Ecoglossário - reportagem de capa da Revista da Folha, 26/08/2010)

Nas referências a James Lovelock, ambientalista de renome mundial, também há citações à energia nuclear, como forma de conter as emissões de carbono. $\mathrm{O}$ tom de alerta é recorrente nas referências às conclusões dos estudos. 
Na reportagem "ONG tentou subornar cientista para questionar IPCC, diz jornal”, publicada em Caderno Especial de 03/02/2007, o secretário-geral do Programa das Nações Unidas para o Meio Ambiente, Achim Steiner, afirmou que era hora de ampliar Quioto. "É mais urgente do que nunca que a comunidade internacional entre em negociações sérias para um novo tratado mundial abrangente para deter o aquecimento global".

Na reportagem "Brasil não monitora mudanças do clima", da editoria de Ciência, 11/04/2007, foi abordada sobre a falta de noção exata de quais seriam as mudanças climáticas mais significativas que estão ocorrendo no Brasil e em toda a América Latina.

$\mathrm{Na}$ cobertura do tema, chamam atenção algumas imagens marcantes em 2007 que até hoje permanecem no imaginário e são associadas ao tema mudanças climáticas. Uma foto do período demonstra o apelo emocional da discussão, mostrando manifestantes desfilando em Berlim com bonecos representando George Bush, um urso polar e um globo terrestre pegando fogo (legenda de foto publicada na editoria de ciência em 02/06/2007, relacionada a reportagem "Lula critica plano de Bush para conter o aquecimento global").

Na editoria Dinheiro, de 13/05/2007, foi publicada reportagem sobre a preocupação dos brasileiros a respeito do tema aquecimento global. Mostrava que $79 \%$ das pessoas já ouviram falar em aquecimento global, enquanto apenas $19 \%$ não tinham ouvido falar e $1 \%$ não sabia do que se tratava.

A pesquisa foi realizada pelo instituto Ipsos, a pedido do Centro das Indústrias do Estado de São Paulo.

"Para $79 \%$ dos entrevistados, o aquecimento é um risco real que levará o mundo à catástrofe. Consideram uma jogada de marketing $9 \%$ dos entrevistados e $12 \%$ não sabem ou não responderam. Segundo a pesquisa, $72 \%$ dos entrevistados acham que a vida deles será afetada diretamente pelo aquecimento global, e apenas $16 \%$ acreditam que não.

A pesquisa mostra também que $50 \%$ das pessoas acham que 0 desmatamento é o maior vilão do aquecimento global. A indústria vem em segundo lugar, com 16\%. Em terceiro, o aumento de poluentes, com $16 \%$. $O$ desperdício de água e energia e o governo ocupam a quarta posição, com $3 \%$.

Apesar da consciência do problema, chama a atenção na pesquisa o fato de a maior parte das pessoas - 58\% da amostra - dizer que não está fazendo nada para evitar o efeito do aquecimento global. Do total, $22 \%$ afirmam que aderiram à coleta seletiva de lixo, $13 \%$ deixam de comprar produtos que afetam o ambiente e apenas 5\% se preocupam em comprar produtos com embalagens fáceis de serem recicladas." 
Outra pesquisa na mesma linha foi publicada em 06/06/2007, na editoria de Ciência, com o título "Público se preocupa mais com o clima". Desta vez, o público pesquisado foi de usuários da internet, em 47 países.

"A preocupação do público com o clima triplicou nos últimos seis meses, e dois em cada cinco consumidores querem que os governos limitem as emissões de gases-estufa.

Os dados são de uma pesquisa de opinião com 26,4 mil usuários da internet em 47 países, feita pelo Instituto para Mudança Ambiental da Universidade de Oxford, no Reino Unido, e pela consultoria Nielsen Europe."

Exemplo de erro na cobertura, devido a pressa no fechamento ou equívocos de informação de natureza técnica:

A reportagem "Floresta nem sempre esfria o planeta", publicada na editoria de Ciência, em 25/04/2007, informou incorretamente que, "se as florestas no norte do mundo continuassem sendo derrubadas como hoje, a temperatura média do planeta poderia ficar até $6^{\circ} \mathrm{C}$ maior". O certo era $6^{\circ} \mathrm{C}$ menor. A informação foi corrigida, na seção "Erramos".

A publicação da seção "Erramos" ocorre sempre na página 3 e é uma forma de corrigir os erros veiculados pelo jornal. Ressalte-se que existe um sistema de avaliação interno que contabiliza o desempenho de cada profissional e dentre eles consta o critério de erros. Obviamente não são todos os erros possíveis de serem corrigidos.

$\mathrm{Na}$ edição de 3/02/2007, Caderno Especial, no texto "Infra-estrutura urbana e saúde pública deverão ser repensadas”, o pesquisador José Marengo foi entrevistado. Um ponto importante para a discussão do tema mudanças climáticas e a questão ambiental foi comentada pelo entrevistado: a vida nas cidades trouxe mudanças e problemas relacionados ao crescimento desordenado e falta de planejamento ou zoneamento adequado. Não há que se creditar tudo ao efeito das mudanças climáticas.

"São Paulo com qualquer chuvinha vira 'una Venezia'. Isso é resultado de uma mistura dos efeitos das mudanças do clima com coisas que não têm a ver", explica o peruano Marengo, com sotaque carregado.

"As pessoas moram nas encostas e nos leitos dos rios. A cidade está muito impermeável, com muito lixo. Tudo isso precisa ser analisado."

Diferenciar o que é resultado das mudanças climáticas do que é ocasionado por outros fatores é uma das questões que merece atenção. Após o longo período de cobertura e acompanhamento do tema de forma mais ostensiva, 
repórteres especializados já estão mais familiarizados com o tema e tendem a ser mais cautelosos. Perguntar aos especialistas toda e qualquer dúvida sempre é um cuidado importante. A tendência é que os erros técnicos diminuam ao longo dos anos. Nos veículos em que não existe uma estrutura regular de cobertura do assunto há maior possibilidade de ocorrência de erros dessa natureza.

$\mathrm{Na}$ cobertura da COP-13, ficou marcada a discussão predominantemente política, que pôde ser observada ao longo de grande parte do ano.

\footnotetext{
'Mapa do caminho' já tem seu primeiro rascunho

Prévia do texto que vai guiar ações pós-Kyoto precisa superar desvio de rotas

Esboço sugere que nações ricas reduzam suas emissões entre $25 \%$ e $40 \%$ até 2020, mas ainda há resistências de vários países em Bali

Claudio Angelo

Enviado especial a Bali

"Não cozinhe o clima". A frase, estampada num termômetro gigante no Centro Internacional de Convenções de Bali, é ironicamente cruel para quem chega ao local sob um sol de $32^{\circ} \mathrm{C}$ e uma umidade do ar de $97 \%$. Mas ontem, no final da primeira semana de negociações na COP-13, a conferência do clima de Bali, ela serviu para reforçar um alerta: o "mapa do caminho", o esboço de negociação do regime climático que vai entrar em vigor após Kyoto, ainda precisa superar alguns desvios de rota.

Um rascunho do mapa circulou ontem em Bali. Ele reconhece que, para evitar os piores efeitos da mudança climática, os países industrializados (o chamado Anexo 1) precisarão reduzir suas emissões entre $25 \%$ e $40 \%$ até 2020. O texto diz ainda que as emissões globais de gases-estufa precisam chegar ao pico em 10 ou 15 anos, para depois então cair para "muito menos que a metade" dos níveis de 2000, até 2050.

Reconhece também que os esforços feitos hoje para implementar a Convenção do Clima são insuficientes para resolver o problema do aquecimento global, do qual as evidências científicas são "inequívocas". Mas sua aprovação pelos ministros que chegam nesta semana a Bali para o segmento de alto nível da COP, que começa na quarta-feira, ainda enfrenta resistências de vários países."
}

$\mathrm{Na}$ edição de 21/06/2007, editoria de Ciência, foi noticiado que a China passou os EUA e se tornou o maior poluidor do planeta, referindo-se às emissões de $\mathrm{CO}_{2}$ em valores absolutos. No cálculo per capita, ou quanto cada cidadão emite, os EUA continuavam na liderança. A reportagem "China passa os EUA e se torna o maior poluidor" trouxe no parágrafo final novamente referência ao combate ao efeito estufa.

"Os chineses estão tentando responder ao cerco diplomático. No começo do mês, divulgaram sua estratégia nacional de combate ao efeito estufa, pela qual se comprometem, por exemplo, a aumentar a eficiência de seu uso de energia em $20 \%$ até 2010." 
No caderno Veículos, a reportagem "Automóveis híbridos devem salvar Terra", de 11/02/2007, apresenta, além do título apocalíptico, uma abertura também imprecisa:

"Temperaturas $4^{\circ} \mathrm{C}$ mais altas, praias com menos areia, furacões e tufões mais intensos. $O$ cenário de caos anunciado pelo IPCC (Painel Intergovernamental sobre Mudança Climática), divulgado no dia 2, coloca os automóveis como um dos principais vilões do ambiente."

Ao continuar a leitura do material, percebe-se que a abordagem do assunto foi interessante, comparando informações sobre diferentes marcas e modelos em termos de emissões e exemplificando como diferentes países tentaram começar a atacar o problema de emissões. Mas para chamar atenção do leitor, o repórter cometeu incorreções técnicas. Logo na abertura deixou o leitor com informações parciais, sem explicações sobre a elevação de temperatura, que na verdade se baseia em um dos cenários traçados pelos pesquisadores. Também as generalizações - praias com menos areia, furacões e tufões - reforçou a ideia que povoa o imaginário sobre as catástrofes relacionadas às mudanças climáticas.

É da editoria Cotidiano um bom exemplo de como o jornalismo pode ajudar na questão ambiental de forma ainda mais intensa, gerando reflexão. A moda de neutralizar emissões e adotar medidas de compensação como o plantio de árvores pela internet, que caracterizaram os hábitos dos cidadãos naquele primeiro momento de maior contato com a problemática envolvendo as mudanças do clima, pautou a reportagem da Revista da Folha, suplemento dominical sobre diversos assuntos. Especialista em psicologia sócio-ambiental pontuou de forma bastante interessante a discussão. Entretanto, trata-se de apenas um parágrafo, um pequeno espaço ante uma cobertura ostensiva de vários veículos no sentido de mostrar catástrofes.

"Ninguém duvida que o aquecimento global seja um problema. Provoca derretimento de geleiras, elevação do nível dos mares, inundações e muita, muita culpa. Culpa por atividades cotidianas, como andar de carro, que polui e destrói a camada de ozônio, e até tomar um banho longo, que põe em risco um recurso finito.

Para Eda Tassara, 68, coordenadora do Laboratório de Psicologia SócioAmbiental e Intervenção da USP, o debate, em vez se transformar numa discussão sobre a mudança de hábito dos consumidores, foi canalizado para as catástrofes. Portanto, é natural que as pessoas se sintam culpadas e impotentes. E reajam com respostas imediatas, como clicar num site ecológico." 
(Caos ecológico leva pessoas a neutralizarem culpa e carbono, Revista da Folha, 26/08/2007)

O cenário de catástrofe, sem dúvida, dominou o noticiário nesse período de 2007. Podem ser detectados alguns exageros e expressões e modismos, visões apocalípticas e proféticas, como salvar o clima, uso de verbos e expressões relacionadas ao aquecimento para provocar envolvimento do leitor, porém é importante ressaltar que o texto é rico em informações e traz sínteses importantes sobre os eventos e pesquisas desenvolvidas.

A produção de um caderno especial (03/02/2007), contando inclusive com a colaboração de pesquisadores brasileiros que trabalharam nos relatórios do IPCC foi um recurso do jornal que auxiliou no melhor entendimento da questão por parte dos leitores.

Para as edições de 2007 do jornal O Estado de S. Paulo, foram analisadas 136 reportagens da editoria Vida \& (onde são publicados os temas de ciência e meio ambiente), 17 da editoria Economia, 15 artigos da seção Espaço Aberto (artigos assinados), 5 editoriais, 4 reportagens da editoria Internacional, 3 da editoria Nacional, 3 do Caderno Especial (suplemento publicado por ocasião do terceiro relatório do IPCC de 2007), 8 artigos da editoria Opinião (artigos assinados), uma nota (coluna assinada - Celso Ming). Entre os textos da editoria Vida\& a abordagem predominante é apresentada na TAB. 4.4.

TABELA 4.4 - Textos sobre mudanças climáticas da editoria Vida\& de OESP em 2007

\begin{tabular}{lc}
\hline Tema & Incidência \\
\hline Políticas envolvendo mudanças climáticas & $41 \%$ \\
\hline Enfrentamento das mudanças climáticas em geral & $20 \%$ \\
\hline Consequências ou efeitos das mudanças climáticas & $11 \%$ \\
\hline Pesquisas sobre mudanças climáticas & $10 \%$ \\
\hline Combate ao desmatamento & $8 \%$ \\
\hline Inventário de emissões & $4 \%$ \\
\hline Mercado de carbono & $3 \%$ \\
\hline Impacto econômico & $2 \%$ \\
\hline Outros & $1 \%$ \\
\hline
\end{tabular}

Fonte - Elaborada pela autora 
Entre os textos da editoria Vida \&, houve predominância de matérias com abordagem política (41\%). Combate às mudanças climáticas foi tema predominante em $20 \%$ dos textos e $10 \%$ tinham relação predominante com pesquisas relacionadas ao tema mudanças climáticas desenvolvidas em instituições científicas. Conseqüências das mudanças climáticas e/ou seus efeitos foi mensurado como abordagem principal em 10\% dos textos. Desmatamento e combate ao desmatamento foram abordagem principal em $8 \%$ dos textos. Inventário de emissões foi o enfoque principal de 6 textos (4\%). Quatro textos $(2,9 \%)$ abordavam mercado de carbono, três textos $(2,2 \%)$ com predominância sobre o impacto econômico das mudanças climáticas.

A dinâmica da cobertura foi bem semelhante à encontrada no jornal Folha de S. Paulo, em termos de distribuição dos assuntos. Futuro quente e sombrio e previsões alarmantes foram alguns termos encontrados em termos de titulação. 'Guerras mundiais são fichinha perto disso' e 'Não haverá refúgios no país' são títulos publicados a partir de declarações de cientistas em entrevistas coletivas. O conteúdo de várias reportagens fica semelhante, sobretudo quando se refere a eventos como a divulgação dos relatórios ou cobertura de COP, mas a diferença no título é o detalhe.

Na reportagem de 2/02/2007, "Mudanças superaram projeção da ONU de 2001", a afirmação de que os países seriam pressionados a mudar seu estilo de produção e consumo.

"O dado desmente quem diz que a Terra está apenas passando por mais um ciclo natural e que as atividades humanas têm pouco impacto no clima. Uma saída para os "céticos do aquecimento" é colocar o próprio IPCC em dúvida tese difícil de se defender com esta análise na Science.

Com o fato consumado, o debate político e o econômico mudam. Países que não assumiram ainda sua parcela de culpa, especialmente os Estados Unidos, serão pressionados a mudar seu estilo de produção e consumo. Nações em desenvolvimento, como o Brasil, terão de encontrar alternativas para frear suas emissões de gases-estufa sem perder o trilho do crescimento. Depois deste, o próximo estudo do IPCC só sai em 2012, quando termina o prazo inicial do protocolo, como lembra o brasileiro Paulo Artaxo, membro do painel. "Este relatório será a base das negociações pós-Kyoto. Imagina as repercussões econômicas..."

$\mathrm{Na}$ arena política, os debates seguem um outro ritmo. Apesar de todos os estudos até a presente data mostrando o quanto se ganha ao evitar a degradação ambiental e claro diminuir as emissões de gases de efeito estufa e 
combater desmatamento, fatores diretamente envolvidos no fenômeno aquecimento global, as iniciativas são ainda incipientes. O poder de iniciativa está nas mãos dos governos e a sociedade ainda não assumiu um papel engajado, participativo nesse processo. Os formadores de opinião esboçam um nível de informação e se declaram interessados nas questões ambientais, mas estariam eles praticando ações ambientalmente amigáveis? Estariam dispostos a mudar atitudes e qual o nível desse engajamento, quando isso significa mudanças em padrões de consumo?

A abordagem jornalística, carregada de "cor local", procurando aproximar o leitor e mexer com seus sentidos, pode causar algum incômodo para alguns pesquisadores. Um exemplo extraído da cobertura do Estado, editoria Vida \&, de 3/02/2007:

“(...) A descrição feita pelo pesquisador do Instituto Nacional de Pesquisas Espaciais (Inpe) José Antonio Marengo, um dos cientistas que participaram do Painel Intergovernamental de Mudanças Climáticas (IPCC), é de fazer inveja a roteiristas de filmes de catástrofes. "Não haverá refúgios climáticos. Todos vão sentir." (...)"

$O$ pesquisador respondeu aos questionamentos do repórter e acrescentou suas observações e comentários. Na hora de relatar o tema, o repórter utiliza comparações, registra impressões, utiliza figuras de linguagem para tornar a narrativa interessante. Nas vezes em que excede o uso dessas figuras ou que titula de forma diversa daquele contexto em que o pesquisador inseriu a declaração ou que a pressa no fechamento impede maiores refinamentos de conteúdo ou de linguagem pode ocorrer o problema. Bem utilizadas, as figuras de linguagem são uma forma de prender a atenção do leitor.

Em outro texto da mesma editoria, de 3/02/2007, 'Guerra mundiais são fichinha perto disso', uma frase foi extraída do depoimento do pesquisador para titular a reportagem. No entretítulo, uma negação ao título: "Não é o 'fim do mundo', diz ele. Mas, com ou sem a colaboração dos países, a temperatura do planeta vai continuar subindo."

Ao longo do texto, que traz uma entrevista com pesquisador que trabalhou para o IPCC, respostas para algumas questões e o trecho a partir do qual foi elaborado o título:

"Qual é o impacto deste cenário para o homem?

Na história nunca se chegou nem perto de um problema desta envergadura. $A$ $1^{\underline{a}}$ e a $2^{\underline{a}}$ Guerras Mundiais são fichinha perto disso. E não existe um órgão 
para tomar decisões desse âmbito, nem a ONU. Enfrentaremos dificuldades seriíssimas.

Alguma medida, como o Protocolo de Kyoto, pode impedir as interferências climáticas perigosas?

$O$ estrago já foi feito. O ponto de retorno já passou. Um aumento de $3^{\circ} \mathrm{C} \mathrm{em}$ 100 anos é muito alto. O dióxido de carbono tem um tempo de vida na atmosfera de 100 anos. Se cessássemos hoje as emissões, o efeito estufa seria significativo por pelo menos mais uns 500 anos."

As mesmas incorreções com relação a combater o efeito estufa, como se ele fosse algo maléfico, são encontradas nas edições de 2007 de O Estado de S. Paulo, como no entretítulo da reportagem da editoria Vida \&, de 11/02/2007, "Rotina ecológica protege o ambiente".

"Ao promover algumas mudanças de hábito, qualquer pessoa pode ajudar a combater o efeito estufa (...)"

Mas logo ao iniciar a reportagem, a expressão correta (combate ao aquecimento global), que faz parte da declaração de um entrevistado:

"Tire a gravata e ajude no combate ao aquecimento global." A frase, que à primeira vista pode parecer meio esdrúxula, é a resposta que Helio Mattar, diretor-presidente da ONG ambiental Instituto Akatu, tem dado às pessoas que chegam aflitas para conversar com ele depois da divulgação, no dia 2, do relatório que prevê mudanças climáticas drásticas até o final do século. " $E$ agora, o que eu faço?", é a interrogação que tem passado pela cabeça de muita gente diante da constatação inequívoca de que o aquecimento global é culpa de todos nós.

O título de 7/04/2007, editoria Vida \&, "Efeito estufa agravará fome e sede pode atingir 1 bilhão de pessoas", também apresenta a mesma incorreção, já que o efeito estufa é o processo natural, sendo seu incremento o responsável pelos problemas climáticos que desafiam cientistas, legisladores e governantes.

Os mesmos recursos de glossários, guias e dicas sobre como combater o aquecimento, como adotar atitudes "ecológicas" e ajudar a "salvar o planeta" estiveram presentes na cobertura.

Um exemplo de como o jornalismo de ciência pode ser também investigativo pode ser atestado na edição de 11/02/2007, editoria Vida \&:

\section{"Programas para mudanças climáticas têm gasto limitado}

O Brasil está fazendo sua parte para evitar o aquecimento global? Sim, mas poderia fazer mais, começando por gastar o dinheiro já destinado para esse fim. Uma análise sobre o Orçamento da União mostra que programas não foram tocados ou acabaram sendo executados parcialmente. Um exemplo ajuda a esclarecer o leitor: para promover o desenvolvimento sustentável da Amazônia, um anseio mundial, o governo tinha $R \$ 306$ milhões, porém só utilizou $R \$ 101$ milhões. 
Pelo sistema de consultas Siga Brasil, do Senado, a reportagem do Estado listou cerca de 30 programas de cunho ambiental, relacionados direta ou indiretamente à mudança climática. Todos dos orçamentos de 2003 a 2004, ou seja, no governo Lula. De um total de $R \$ 8,7$ bilhões autorizados, foram empenhados $R \$ 4,6$ bilhões. A execução orçamentária, logo, foi de 52,8\%. Ações para aprimorar a agricultura irrigada, promover estudos de mudança climática ou usar racionalmente água ou energia deixaram de usar todos os recursos possíveis." (...)

A reportagem "Contradição enfraquece relatório sobre clima", de 4/05/2007, editoria Vida \&, buscou enfatizar a questão política prevalecendo em detrimento da técnica, já que a ausência de pesquisas sobre determinada questão abre mais uma possibilidade:

“(...) A falta de pesquisas atuais consolidadas facilitou a pressão política. Dados conflitantes sobre um mesmo tópico permitiram aos governos escolher o raciocínio que melhor Ihes convinha.

Foi com base nessa dicotomia que o IPCC rachou ao longo da semana. Países desenvolvidos, liderados pelos Estados Unidos, e nações em desenvolvimento, representados pela China e com a retaguarda do Brasil, estiveram reunidos em blocos opostos. Eles travaram uma disputa sobre quem deve começar a cortar as emissões de gases-estufa e a pagar a conta.

Países ricos lembraram que as emissões de nações em desenvolvimento serão as que mais crescerão até 2030, portanto seria mais fácil que o controle partisse delas. A delegação americana disse que entre dois terços e três quartos do percentual de crescimento da concentração de CO2 na atmosfera, que pode variar de $25 \%$ até $90 \%$ a mais até 2030 , será responsabilidade dos emergentes.

Os emergentes justificaram que, mesmo com o crescimento, os ricos manterão um índice de emissão per capita mais alto. A China falou de 9,6 e 15,1 toneladas de carbono por habitante nos países ricos - e entre 2,8 e 5,1 toneladas nos emergentes. Além disso, sustentaram as delegações, o passivo histórico cabe às nações industrializadas.(...)"

$\mathrm{Na}$ reportagem "Energia nuclear é considerada uma alternativa", de 5/05/2007, no caderno Vida \&, a menção à energia nuclear como opção para mitigação aos impactos causados pelo aquecimento global soma-se a ponderações a respeito de riscos, como os rejeitos radioativos e o acidente de Chernobyl.

"A energia nuclear foi considerada, pelo relatório do IPCC, uma alternativa concreta aos combustíveis fósseis que pode ser usada no combate ao aquecimento global. A decisão foi bem recebida em especial pelo governo brasileiro, que pretende retomar até o meio do ano seu programa nuclear, segundo o ministro da Ciência e Tecnologia, Sergio Rezende.

A palavra "nuclear" aparece cinco vezes no relatório. São menções rápidas que, no entanto, devem transformar para sempre a relação de cientistas e ambientalistas com a energia obtida pela fissão nuclear.

A classificação de "alternativa" antes era vinculada no imaginário de ecologistas a formas de produção de energia ditas limpas, ou que não geram - ou geram pouca - poluição. A fissão nuclear está longe desse conceito. Não 
apenas produz rejeitos, mas também os mais perigosos do gênero: são radioativos e altamente cancerígenos, na melhor das hipóteses de contato humano. Mesmo com os riscos de acidentes, como o ocorrido em 26 de abril de 1986 na Usina de Chernobyl, na Ucrânia, a fissão entrou para o rol de meios de contenção das emissões de $\mathrm{CO}_{2}$ e demais gases causadores do aquecimento global.

"E uma questão de bom senso. O que mais existe para a maioria da geração de eletricidade que é carbon-free?", questiona lan Hore-Lacy, da Associação Nuclear Mundial.

As cinco referências são breves e não incluem juízos de valor. Na primeira delas, o termo "advanced nuclear power" aparece em um quadro no qual os cientistas e delegados governamentais apontam como conter a poluição atmosférica.

Já na mais extensa, a perspectiva de seu crescimento para os próximos 23 anos é abordada: "A energia nuclear, que foi responsável por $16 \%$ da energia elétrica produzida em 2005, pode ter $18 \%$ do total da produção energética em 2030 se os preços de cotas de carbono forem superiores a US\$50 por tonelada de $\mathrm{CO}_{2}$ emitido", diz, prosseguindo em tom de alerta: "Mas segurança, proliferação armamentista e desperdício seguem como problemas".

Bert Metz, co-presidente do IPCC, enfatizou, no entanto, que isso não é um endosso à energia nuclear: "Isso é absolutamente uma revisão técnica. Não estamos fazendo recomendações políticas, disse."

A reportagem procurou ainda explicitar a citação à opção nuclear mesmo por parte de profissionais que a princípio são desfavoráveis à adoção desta alternativa energética.

"A simples possibilidade de menção da fissão nuclear no relatório final causou controvérsia ao longo da semana, em Bangcoc. Na quinta-feira, Hans Verolme, diretor do Programa de Mudanças Climáticas da WWF, ressaltou ao Estado que a ONG seguia não considerando a energia nuclear como "alternativa" e que não acreditava na sua inclusão no documento do IPCC. Ontem, sua postura foi mais conciliadora: "O relatório adota a neutralidade em relação às alternativas ao petróleo como fonte de energia", julga. "Em um documento de 35 páginas, cinco referências sobre energia nuclear não me parece muito importante. E não há um juízo de valor sobre nenhuma das alternativas, determinando se são boas ou más."

Também a ONG Greenpeace havia se manifestado contra a inclusão da fissão no rol de soluções. Na nota divulgada pela organização após o evento de ontem, contudo, não consta nenhuma crítica ou comentário."

Houve menção à energia nuclear em outras reportagens, pelo fato de o relatório do IPCC considerar a geração nucleoelétrica como opção no combate às mudanças climáticas. Foi publicada reportagem a partir de entrevista com o ministro da C\&T Sergio Rezende defendendo investimentos em energia nuclear ("Ministro quer que Brasil volte a investir em energia nuclear", Vida\&, 04/02/2007) e também reportagem a partir de entrevista com o ambientalista James Lovelock em favor desta forma de energia ("Para ele, fonte oferece segurança", Vida \&, 
06/02/2007). Investimentos da Grã-Bretanha em energia nuclear e o próprio relatório da ONU recomendando energias renováveis em favor do combate às mudanças climáticas e utilização da energia nuclear foram noticiados, conforme 0 texto de 03/05/2007, editoria Vida \&, "Relatório da ONU pedirá que países adotem etanol".

“(...) Outro tema voltado à energia que merece debates intensos entre os delegados, os cientistas e os observadores é a ampliação de usinas nucleares. Os Estados Unidos, por exemplo, pedem sua inclusão no relatório final dessa reunião, que será divulgado amanhã. Ambientalistas acreditam que as fontes renováveis merecem prioridade.

Um pequeno comitê, formado dentro do encontro apenas para tratar desse tema, quer definir a energia nuclear como uma das alternativas para reduzir a emissão de $\mathrm{CO}_{2}$. Contudo, indica que a tecnologia empregada tem limites. $\mathrm{O}$ texto precisa ser aprovado por todos os membros da reunião.

Stephan Singer, da ONG WWF, diz que dificilmente a energia nuclear será retirada do leque de soluções apresentadas pelo IPCC, ainda que diversos grupos digam que ela é muito perigosa e custosa para representar uma alternativa. "Não acreditamos que a energia nuclear seja uma solução."(...)"

A comoção gerada com a causa ambiental e a percepção do risco trazido pela catástrofe climática anunciada foi assunto capaz de alimentar o noticiário e resultou especialmente da estratégia do IPCC de divulgação do relatório. Na pauta nacional, a discussão sobre o plano para enfrentamento das mudanças climáticas foi noticiada pelo jornal em 28/02.

"País prepara plano para enfrentar aquecimento

Com base em estudos de impactos, governo analisa medidas a tomar

Lígia Formenti, Brasília

Erosão de vários quilômetros do litoral, extinção de inúmeras espécies de peixes, aves e répteis, inundação de mangues, aumento de doenças como malária e febre amarela. O cenário é descrito em oito estudos de pesquisadores brasileiros sobre os possíveis efeitos do aumento do aquecimento global no Brasil até o fim deste século. "O processo que se avizinha é avassalador", resumiu a ministra Marina Silva, durante a cerimônia da apresentação dos estudos, ontem, em Brasília.

Encomendada pelo Ministério do Meio Ambiente, a série de estudos deverá servir como ponto de partida para uma discussão considerada essencial por Marina: a criação de um Plano Nacional para enfrentar o aquecimento global. Informalmente, a ministra já iniciou a discussão com alguns colegas de governo. A expectativa é de que, agora, com os estudos em mãos, o assunto seja levado oficialmente ao presidente Lula. "Em quatro meses, é possível já ter um esboço deste plano", calcula o secretário de Biodiversidade e Florestas, João Paulo Capobianco.

A pressa da equipe do ministério se explica. Quanto mais rápido o processo for iniciado, maiores as chances de se tirar benefícios da comoção criada com a divulgação do Painel Internacional de Mudanças Climáticas (IPCC), no início deste mês. No relatório internacional, as previsões são igualmente 
preocupantes. "Não somos ingênuos em imaginar que, se fizermos nosso dever de casa, estaremos livres dos problemas. É preciso um esforço mundial, que todos os países ingressem nessa luta", afirmou a ministra."

Posteriormente, foi noticiada a elaboração de um plano contra mudanças climáticas pelo governo do Estado de São Paulo (29/08/2007). No dia 23/10/2007, os leitores da publicação puderam acessar uma entrevista com Gro Harlem Brundtland, ex-primeira ministra da Noruega que presidiu a Comissão Mundial sobre Desenvolvimento e Meio Ambiente. Este é um exemplo de cobertura diferenciada do tema e um registro importante. A entrevista, assinada por Andrea Vialli, é transcrita a seguir:

"Como uma das mentoras do conceito de desenvolvimento sustentável, como a senhora avalia o avanço da humanidade nessa questão, desde que o conceito foi criado, em 1987?

Temos que admitir que aumentou a consciência em todas as áreas. Temos tido avanços em entender que a questão é intersetorial e requer a participação do setor privado, instituições científicas, governos, ONGs e opinião pública. Mas estamos no meio do caminho. Muitos países passaram a adotar políticas ambientais e investir em novas tecnologias. Muitas das idéias surgidas na Comissão começaram a sair do papel, mas não é suficiente. Não estamos indo na velocidade suficiente. Os ataques terroristas de 2001 desviaram o foco das questões ambientais e só agora retomamos o debate.

Atualmente, têm sido anunciados esforços para refrear os efeitos do aquecimento global, mas os primeiros alertas foram dados há 20 anos. Por que só agora começou essa corrida em direção à sustentabilidade?

Os efeitos da ação humana sobre o aquecimento global foram descritos há 20 anos. Em 1987 já havia sido levantada a necessidade de se ter uma convenção mundial sobre o clima. Isso não ocorreu antes porque havia disputas entre os cientistas sobre o quão clara estava a questão, até onde eles estavam corretos em suas observações. $O$ debate continuou por anos. $E$, enquanto o Protocolo de Kyoto foi criado, negociado e ratificado, o debate continuou. Os EUA disseram que não iam ratificar, pois havia ainda dúvidas em relação aos estudos científicos. Agora, o debate acabou porque os cientistas chegaram a conclusões muito claras. Os EUA pararam de dizer que não têm nada a ver com a questão e duvidam da ciência, embora defendam que as metas de redução de gases de efeito estufa têm de ser voluntárias. É uma posição muito diferente da que eles tinham há um ano. Por isso eu acho que hoje a questão tomou esse corpo. Todo mundo está sendo questionado sobre o que está sendo feito para combater a mudança climática.

O Protocolo de Kyoto é suficiente para reverter os efeitos do aquecimento global?

Mesmo se o Protocolo de Kyoto for implementado à perfeição, não será suficiente. Porque, quando o acordo foi traçado, os países ricos e industrializados eram responsáveis por $30 \%$ das emissões de gases de efeito estufa. Mas as emissões globais estão aumentando por causa da China e outros países emergentes. Não será suficiente, a não ser que se apliquem compromissos de redução para todos os países. Não quero criar um debate aqui e sugerir que Brasil ou Índia tenham os mesmos compromissos de 
redução do $\mathrm{CO}_{2}$ que têm os países ricos. Mas todos os países têm que contribuir de algum modo. É isso que precisa ser negociado, e será o assunto da Conferência do Clima em Bali, em dezembro.

O Brasil tem acenado com o etanol, como uma solução para aliviar o aquecimento global, mas esbarra nos problemas sociais e ambientais associados à sua produção. Como resolver isso?

Eu diria que todos os tipos de energia têm problemas de alguma ordem. É preciso olhar para o que temos e escolher um conjunto de alternativas. Eu sei que o etanol brasileiro tem um lugar nesse cenário. Mas é preciso também ter soluções realmente novas, colocar a pesquisa científica em prática. Só o biocombustível não vai resolver."

A discussão sobre energia nuclear e seu papel no combate às mudanças climáticas também figurou em outras editorias, como Economia e Opinião.

"Adiando o fim do mundo", "Bom senso para evitar o apocalipse" foram títulos de artigos na editoria Opinião. A seção Espaço Aberto trouxe artigos assinados por colunistas de renome em suas áreas de atuação que há anos atuam como colaboradores. Nessa grife de textos, Washington Novaes, jornalista experiente na área ambiental enriqueceu e complementou o noticiário com suas reflexões. Uma delas, de 24/07/2007, merece transcrição literal, posto que seu resumo ficaria aquém do poder de argumentação que contém:

"Duas décadas de advertências. E aí?

Washington Novaes

Costuma o professor Ignacy Sachs, da Escola de Altos Estudos em Ciências Sociais de Paris, citar um de seus mestres poloneses, segundo o qual uma nova idéia precisa de pelo menos duas décadas para ser aceita. Deve ser o mínimo. Isso ficou claro mais uma vez para quem esteve presente às discussões do $2^{\circ}$ Congresso Empresarial para o Desenvolvimento Sustentável, promovido esta semana pelo Conselho Empresarial Brasileiro para o Desenvolvimento Sustentável (CEBDS). Ali - além de haver sido assinado um pacto entre grandes empresas que se comprometem a reduzir suas emissões de gases e outro entre instituições que propõem o fim do desmatamento no País, o aumento no uso de energias renováveis e o estabelecimento de metas nacionais de redução das emissões, entre outros pontos - ocorreu uma discussão sobre os 20 anos do chamado Relatório Brundtland.

Coordenado pela então primeira-ministra da Noruega, a pedido das Nações Unidas, o relatório, com o título Nosso Futuro Comum, consolidou o conceito do que passou a ser chamado de "desenvolvimento sustentável", aquele capaz de atender às necessidades das atuais gerações sem comprometer os direitos das futuras gerações. Nesse documento de abril de 1987, a coordenadora enfatizava que "os cientistas chamaram a atenção para problemas urgentes e complexos ligados à própria sobrevivência do ser humano: um planeta em processo de aquecimento, ameaças à camada de ozônio, desastres que devoram as terras de cultivo". 
Pois, nestas últimas semanas, 20 anos passados, o noticiário continuou a dizer que o buraco na camada de ozônio permanece em níveis recordes e assim permanecerá por muito tempo, que o drama do aquecimento global continua sem solução, que continuamos a consumir mais recursos naturais do que a biosfera terrestre pode repor. E o ex-secretário da ONU Kofi Annan voltou a advertir: "Se nós não colocarmos o clima sob controle, se não enfrentarmos os desafios do meio ambiente, todos os esforços que estamos fazendo serão inúteis." E o disse no mesmo dia em que se anunciava um terceiro relatório complementar do Painel Intergovernamental sobre Mudanças Climáticas (IPCC) - a ser divulgado a 4 de maio, na Tailândia -, mostrando que precisamos de mudanças drásticas para evitar que a concentração de gases na atmosfera ultrapasse 450 partes por milhão (ppm) $e$ as perdas no produto bruto mundial superem 3\%. Se a concentração chegar a 530 ppm, a perda ficará entre $5 \%$ e 20\% (como já advertiu o chamado Relatório Stern).

Nas discussões sobre os 20 anos do Relatório Brundtland, em São Paulo, ficou claro que o mestre polonês tem toda a razão. Já em 1988, o IPCC divulgou seu primeiro relatório, basicamente com as mesmas advertências do último (fevereiro de 2007): a temperatura do planeta já se elevara quase 0,8 grau Celsius em conseqüência de ações humanas; o aquecimento estava intensificando secas, inundações, furacões, aumentos de temperatura e perdas de culturas, etc. Quatro anos depois, em 1992, no Rio de Janeiro, assinava-se a Convenção do Clima, que recomendava a redução das emissões de gases poluentes pelos países industrializados, assim como a convenção sobre a diversidade biológica para tentar evitar que ela continuasse a se perder em alta velocidade. Assinava-se, também, a Agenda 21 mundial, com as estratégias e ações capazes de resolver os graves problemas sociais e ambientais do mundo. Maurice Strong, secretário da Eco92, dizia: "É a nossa última oportunidade de rever os rumos planetários, sob pena de declínio da espécie humana."

Cinco anos depois, na Rio + 5, Strong voltava à carga: "Precisamos reinventar a civilização industrial." E o ex-primeiro-ministro soviético Mikhail Gorbachev sentenciava: "Precisamos de novo paradigma; a civilização atual chegou a seu fim, exauriu as suas possibilidades. Temos de chegar a um consenso sobre novos valores. Em 30 a 40 anos a Terra poderá viver sem nós."

Ouvidos moucos. Na Rio + 10 (Johannesburgo, 2002), o presidente da França, Jacques Chirac, depois de estigmatizar a insustentabilidade dos padrões de produção e consumo no mundo, assim como a concentração da renda (gerando as inacreditáveis desigualdades e dramas sociais, que ele chamou de "apartheid mundial"), chicoteava: "As futuras gerações nos cobrarão; 'vocês sabiam', dirão elas, 'e nada fizeram'”.

Chega 2006. O relatório do Programa das Nações Unidas reafirma que estamos consumindo $25 \%$ além da capacidade de reposição do planeta. $O$ Relatório Stern diz que, por causa do clima, caminhamos para uma catástrofe econômica e só temos uma década para tentar pelo menos minimizar os prejuízos. Um terceiro relatório, da Organização para a Alimentação e a Agricultura (FAO), da ONU, assegura que as culturas de carnes precisam reduzir seu impacto sobre o meio ambiente pelo menos em 50\% - mas deverão aumentá-lo em 100\% até 2020. 
Este ano, o IPCC confirma, com grau de certeza muito maior, tudo o que vinha dizendo desde 1988. Mas os Estados Unidos, maior emissor de gases, continuam se recusando a assumir metas de redução - assim como a China, que, em breve, se tornará o maior emissor, o Brasil, quarto maior, a Índia e outros países. Só nesta semana, 15 anos depois de o País haver assinado a Convenção do Clima, o Ministério do Meio Ambiente está criando uma Secretaria de Mudanças Climáticas, depois de haver anunciado, há poucos dias, que "daqui a quatro meses" estará pronto um plano nacional para essa área. Na Agenda 21 nacional, a proposta de construção de um capítulo sobre esse tema - ali apresentada pelo autor destas linhas - foi aprovada há uns dois anos, mas não conseguiu sequer chegar ao papel, quanto mais a uma discussão.

Talvez o mestre polonês ainda fosse muito otimista. Vinte anos parecem pouco, mesmo diante de evidências dramáticas."

A possibilidade de conciliar diferentes visões e a contribuição multidisciplinar ficam patentes ao se analisar os textos distribuídos nas várias seções do periódico. Os conteúdos são complementares e mesmo quando se contradizem em alguma medida tornam o tema ainda mais interessante.

No artigo assinado por Otaviano Canuto, em 17/02/2007, editoria Opinião, que começa de forma provocativa, foi citado um trabalho científico e é informada a referência para busca pela internet. Fórmula interessante para os que desejam se aprofundar na questão.

"Aquecimento assimétrico
Otaviano Canuto
"No ano passado, durante visita de diretores-executivos do Banco Mundial à
Sibéria, uma autoridade local responsável pela gestão de gigantesca área
florestal surpreendeu a todos com uma pergunta. Entre um brinde e outro
num jantar, indagou o "por que de tanta inquietação com o aquecimento
global!
A pergunta, feita em tom de brincadeira, ilustra um dos obstáculos para o
enfrentamento do problema da mudança climática, qual seja, o fato de que
suas causas e conseqüências, além de cercadas de inevitável imprecisão,
tendem a ser avaliadas sob prismas e interesses diversos. O relatório mais
recente do Painel Intergovernamental de Mudanças Climáticas da ONU
(IPCC), publicado em 2 de fevereiro, reforçou a opinião científica de que o
mundo está aquecendo, de que as emissõe humanas de dióxido de carbono
têm ampla dose de responsabilidade e de que haverá ainda substancial
aquecimento ao longo do presente século. Mas se sabe que os impactos não
serão geograficamente uniformes. (..)
Há também a assimetria entre causas e efeitos. As causas são globais: como
os gases estufa se misturam de modo uniforme na atmosfera, de um ponto de
vista ambiental não importa de onde se originam no planeta as emissões. Isso
em si já gera um "problema de ação coletiva", vale dizer, na ausência de
algum mecanismo que inclua todo mundo fazendo algo em simultâneo, a
tentação de deixar que outros incorram no custo de cortar emissões de
carbono tende a predominar, levando ao fracasso coletivo. Para piorar, como
as conseqüências não são uniformes, a disposição a incorrer em tais custos 
de mitigação pode não guardar proporcionalidade com as responsabilidades nas causas. Será necessária muita força moral para fazer prevalecer o princípio de "justiça social planetária" no esforço diplomático global, com ônus refletindo responsabilidades, em lugar do simples cálculo de custos e benefícios. (...)"

*Otaviano Canuto, diretor-executivo no Banco Mundial, é professor da FEAUSP. Home page: www. worldbank.org/eds 15

A controvérsia em torno do tema mudanças climáticas envolvendo os chamados céticos do clima foi discutida no artigo de 06/09/2007, publicado na seção Espaço Aberto. Afirmou o artigo que os céticos não têm espaço para discussão, posto que as conclusões do IPCC são tidas como verdades absolutas, sem espaço para o contraditório e os cientistas que criticam os relatórios seriam tratados como "dissidentes". A argumentação do autor, muito mais profunda, é de que os discursos romântico e científico se fundiram, criando uma relação pósmoderna, no sentido de proteger a criação.

\section{"A heresia de Bento}

\section{Demétrio Magnoli}

Diante de meio milhão de jovens católicos reunidos em Loreto (Itália), o papa Bento XVI conclamou a humanidade a "salvar o planeta, antes que seja tarde demais". No sermão papal, o imperativo de "proteger a Criação" ganhou uma descrição pós-moderna, na qual se fundem os discursos romântico ("recriar uma forte aliança entre o homem e a Terra") e científico ("um tipo de desenvolvimento que nem sempre tem protegido os delicados equilíbrios da natureza"). Segundo a tradição cristã, o Mal está no homem. Na heresia de Bento, o Mal é um fruto do homem, mas está fora dele e se apresenta sob as formas de economia e tecnologia.

A idéia do apocalipse antecede o cristianismo. Num tablete de argila assírio, datado de 2800 a.C., pode-se ler: "Nossa Terra está degenerada nesses últimos tempos. Há indícios de que o mundo está rapidamente chegando ao fim. Suborno e corrupção generalizaram-se." Exceto pela última frase, cuja atualidade tem outros sentidos, a profecia poderia servir de epígrafe ao mais recente relatório do Painel Intergovernamental sobre Mudança do Clima (IPCC) a respeito do aquecimento global. O fim do mundo é uma melodia ancestral, inscrita profundamente no espírito humano. Hoje, a sua proclamação aproxima a religião canônica de Roma da religião pagã do ambientalismo.

Na tradição cristã, fogo e inundações anunciarão o fim da era do pecado e o início do Milênio. Talvez por isso as profecias apocalípticas do IPCC nos soem tão estranhamente familiares: a linguagem de fundo é a mesma. Uma edição da revista Life, de setembro de 1993, trazia a manchete: $O$ ano do tempo assassino. Por que a natureza enlouqueceu? Não há ciência nenhuma na imputação de insanidade e na atribuição de uma vontade homicida à natureza. Mas essa manchete se converteu em padrão, num tipo de verdade 
evidente de aceitação universal. Como entender o fenômeno sem aludir às camadas recônditas da cultura?

Os ambientalistas contemporâneos marcham atrás da bandeira da ciência, ao menos no domínio crucial do aquecimento global. A associação é estranha, quase espúria. O ambientalismo emergiu no interior do movimento romântico, no outono do século 18 . Os românticos reagiam à filosofia das Luzes, contestando o progresso e o mundo artificial da ciência e das tecnologias. Eles adoravam um passado idealizado, pleno de pureza, tecido com os fios da emoção. Civilização e natureza lhes pareciam pólos opostos e inconciliáveis: a primeira, fonte contaminada da perdição; a segunda, refúgio intocado e salvação.

(...) Nos relatórios do IPCC, sob a densa massa da linguagem científica, não é difícil identificar o pulso característico do romantismo, que se revela por inteiro na recepção midiática dos diagnósticos e prognósticos sobre a dinâmica dos climas. Hoje, a imaginação popular assimilou a curiosa idéia de que a natureza foi acometida por uma doença, em razão da ruptura dos seus "delicados equilíbrios". Os sintomas da moléstia transpareceriam em incontáveis eventos meteorológicos, como os dias muito quentes de verão, as noites sem brisa, as chuvas torrenciais, as tempestades tropicais e os furacões.

A ciência não explica a aparente unanimidade construída em torno dos relatórios do IPCC, que se sustentam sobre sofisticados aparatos de modelagem computadorizada e se vestem nas roupagens da estatística de probabilidades, mas nos chegam como profecias oraculares. Há cientistas devotados que criticam duramente esses relatórios, mas ninguém os repercute, como se a ciência pudesse excluir a divergência. Os críticos sérios enfatizam as incertezas sobre a magnitude do aquecimento global e sobre 0 grau de interferência humana no fenômeno, mas tudo se passa como se houvesse respostas incontestáveis à disposição. Os que divergem, no campo científico, são tratados como dissidentes nos regimes totalitários - isto é, como loucos, ou mercenários a soldo de companhias petrolíferas.

Não é a ciência, mas arraigadas tradições culturais que transformam uma tese bem fundamentada na proclamação de uma verdade absoluta. $A$ "religião da natureza" tem um apelo essencial no imaginário da sociedade urbana e industrial. A idéia de uma natureza primeva, sublime, que está lá fora e precisa ser protegida dos fluidos envenenados da civilização ganhou sua expressão mais extremada na profecia do apocalipse climático. A incorporação desse apocalipse pela narrativa da lgreja, realizada no encontro de Loreto, opera por meio da identificação entre natureza e Criação. 0 sermão papal chegou a reproduzir literalmente a idéia da natureza como inspiradora de espiritualidade, um tema caro aos pioneiros do ambientalismo(...)."

Para a revista Veja em 2007, foram duas capas e uma edição especial

(Mulher). No total, 15 edições trouxeram reportagens relacionadas às mudanças climáticas. Em 29 edições foi publicado algum texto relacionado ao tema, compreendendo cartas, notas e frases. Em uma das edições, incorreções técnicas com relação a fontes de emissão de gases de efeito estufa apresentadas 
de forma incompleta pela revista e conceituação do termo - erros já apresentados ao longo do ano anterior pela publicação - motivaram carta de um leitor corrigindo a publicação. Outros erros técnicos se tornaram recorrentes. Palavras catástrofes, devastação e afins povoaram o noticiário.

$\mathrm{Na}$ edição 1990, de 10/01/2007, duas cartas de leitores chamam atenção: uma relacionada às soluções para combater as mudanças climáticas, listadas em edição anterior; outra, contendo comentário sobre a opção pela energia nuclear.

"A oitava megassolução seriam a educação e a conscientização. Consumimos demais. Desperdiçamos demais. Ninguém abre mão de seus pseudoconfortos. Escola, TV e pais continuam a formar crianças consumistas. Um padrão insustentável.

Karla Aharonian - São Paulo - SP"

"A proposta de substituir termelétricas por usinas nucleares não pode avançar por uma simples razão. Dificilmente será encontrada uma solução aceitável para o descarte do lixo radioativo. No entanto, com apenas $10 \%$ dos custos da construção de 300 usinas nucleares é possível investir em pesquisa, modernização e na eficiência das termelétricas, visando a reduzir a produção de $\mathrm{CO}_{2}$ em aproximadamente dez anos.

Misael Martins, Biólogo, especialista em gestão ambiental - Santo André, SP"

Na edição 1991, de 17/01/2007, um leitor corrigiu informação publicada pela revista.

"Gostaria de destacar dois pontos: o dióxido de carbono $\left(\mathrm{CO}_{2}\right)$ e o metano $\left(\mathrm{CH}_{4}\right)$ não são resultantes da atividade humana, apenas. Vale lembrar que o primeiro faz parte do processo de respiração dos seres vivos e o segundo, dos processos de decomposição da matéria orgânica. Portanto, ambos são processos naturais. O problema é a interferência humana em ampliar a emissão desses gases, como nos casos da queima de combustíveis fósseis ou queimadas (caso do $\mathrm{CO}_{2}$ ) ou o depósito de lixo em locais abertos, no caso do $\mathrm{CH}_{4}$. O efeito estufa é um processo natural que faz com que a temperatura média no planeta seja de 15 graus Celsius positivos. Caso contrário, seria de 15 graus Celsius negativos, impossibilitando a rica biodiversidade existente. $A$ questão é o aumento do efeito estufa, que acarreta o aquecimento global.

Rogério Araújo, Consultor ambiental, mestre em gestão e auditoria ambiental - Maceió, $A L^{\prime \prime}$

Na edição 1995, de 14/02/2007, foi publicada uma entrevista com o brasileiro presidente da empresa Alcoa, Alain Belda, afirmando que as empresas precisam ajudar a combater o aquecimento global. No texto "É hora de agir", foi publicada a informação de que a Alcoa se juntou a outras nove grandes corporações para pressionar o governo americano a estabelecer metas 
ambiciosas de redução de $\mathrm{CO}_{2}$ nos Estados Unidos. "A redução das emissões é urgente e, quanto antes começarmos, melhor para os negócios", afirmou Belda.

Na edição 1996, de 21/02/2007, em reportagem "A neutralização da culpa" afirmou-se que plantar árvores para compensar a emissão de poluentes não alivia o efeito estufa, mas é parte da solução.

"De tempos em tempos, práticas criadas para reduzir a degradação do meio ambiente ganham notoriedade especial. Com o passar dos anos, algumas conquistam mais solidez e a atenção quase exclusiva das pessoas. Dois exemplos recentes são a febre de consumo de alimentos orgânicos e a "neutralização", uma invenção de economistas, especialistas em barganhas. A barganha do "comércio verde" é baseada na idéia de que quem polui a atmosfera pode e deve fazer alguma coisa para compensar, ou neutralizar, a agressão."

Na edição 1997, de 28/02/2007, "Como o calor vai afetar o Brasil”, novamente houve referência aos gases de efeito estufa como sendo tóxicos. Nem sempre o poluente é tóxico ${ }^{19}$. O erro recorrente ficou enraizado e foi transmitido ao público outras vezes. Palavras catástrofes, devastação e afins povoaram o noticiário.

"Não se passa uma semana sem que surjam evidências dos efeitos desastrosos do aquecimento global no planeta. Caso não se diminuam as emissões de gases tóxicos que aumentam o efeito estufa, dizem as previsões, as catástrofes se tornarão cada vez mais freqüentes $e$ devastadoras."

Na edição 1997, de 28/02/2007, foi publicada uma entrevista com o exsecretário executivo do Fórum Brasileiro de Mudanças Climáticas Fábio Feldman. Duas declarações do entrevistado são destacadas a seguir:

"Há um enorme descompasso entre o que propomos aos outros nos fóruns internacionais e o que realizamos dentro de casa"

"Estamos diante de um dos maiores desafios do mundo moderno, que é controlar o consumo. Enquanto muitos enxergam a aquisição de bens como um direito pessoal, é preciso salientar que esse mesmo direito pode afetar a qualidade de vida de maneira geral."

Reportagem de 21/02/2007, edição 1996, tratou da compensação para emissões de $\mathrm{CO}_{2}$. Também foi mencionada a existência de algum debate sobre a influência humana no aumento do efeito estufa:

${ }^{19}$ Um exemplo de gás poluente não tóxico é o freon, utilizado como propelente nos medicamentos para doenças respiratórias. 
“(...) Quem não se dispõe a plantar sua própria árvore neutralizadora pode recorrer a especialistas. Entidades ambientalistas e ONGs podem plantar árvores a pedido da pessoa disposta a tornar sua presença menos onerosa para a saúde ambiental do planeta. Pagam-se pelo serviço entre 10 e 30 reais por muda. O plantio não precisa ocorrer, obviamente, na região onde 0 dióxido de carbono foi emitido. Existe ainda algum debate acadêmico sobre a real influência humana na aceleração do efeito estufa - fenômeno que, em níveis normais, garante a existência de vida na Terra. Mas, do ponto de vista da percepção popular, essa questão está selada. A vida civilizada oferece risco ao planeta. Ponto. Quem puder fazer alguma coisa para ajudar estará sendo um terráqueo responsável.(...)"

A legenda de uma foto mostrando um casal que aguardava a chegada de seu filho mostrou o plantio de árvores, modismo que esteve retratado em todos os veículos analisados.

"Com sete árvores, o administrador de empresas Ronney da Cunha vai neutralizar o MBA que cursou em 2006. Gostou da idéia. Ele e sua mulher, Denise, planejam neutralizar o nascimento de Gabriel, o segundo filho do casal"

A argumentação sobre o impacto da atitude de buscar neutralizar emissões com o plantio de árvores trouxe subsídios para a discussão sobre a eficácia da medida, um ponto positivo na abordagem.

“(...) Mas qual é a real eficácia da neutralização? Para alguns cientistas, ela é apenas a materialização do sonho quintessencial do politicamente correto acomodado: nenhum hábito de produção e consumo precisa ser mudado, desde que se plantem algumas dezenas de mudas. Com a neutralização, dizem esses críticos, a poluição torna-se moralmente permitida - ou pelo menos um pouco mais aceitável. Além disso, ainda que as árvores novas funcionem como filtros, tirando o $\mathrm{CO}_{2}$, calcula-se que seria preciso cobrir com elas cada metro quadrado de toda a superfície do planeta para neutralizar o excesso de dióxido de carbono acumulado na atmosfera. Tudo isso é verdade. Mas a ciência ambiental é ainda tão especulativa que tanto o cético quanto o fanático preservacionista podem estar errados. Na dúvida, é bom evitar os excessos. Ainda que não resolva o problema do efeito estufa, a neutralização é parte da solução. "É melhor neutralizar do que não fazer nada. É um começo", diz o engenheiro florestal Paulo Braga, diretor da Max Ambiental, empresa que elabora projetos de neutralização de carbono."

Fica evidente a utilização incorreta do termo efeito estufa, utilizado como sinônimo de aquecimento global. Também a questão de se abordar a ciência ambiental como especulativa é algo inadequado.

$\mathrm{Na}$ elaboração de materiais especiais, acessíveis no site da revista, na seção "Em profundidade", houve a colaboração de especialistas (2008), revisando conteúdos relacionados a respostas e dúvidas sobre o tema. A iniciativa permitiu maior correção nas afirmações. 
A edição 2003, de 11/04/2007, teve grande repercussão entre os leitores da publicação. A capa, impactante, mostrava três ursos polares abraçados. A foto somava-se a outras da edição, mostrando urso vasculhando lixo, no Canadá e icebergs que se desprenderam das geleiras. O urso polar está ameaçado pela redução da área de mar congelado, descreve a legenda. Ou seja, o apelo emocional é forte. Os textos refletiam viagens de repórteres ao Ártico e à Antártica, para "conferir os estragos causados pelo aquecimento global". Os textos "Como o aquecimento dos pólos afeta o clima e eleva o nível dos oceanos", "Onde o desastre já começou", "As lições da Antártica para o clima", "A explosão criativa" e "Todo mundo quer ajudar a refrescar o planeta", além de fotos e vídeos disponíveis no site ajudaram a pontuar uma história de forte empatia com o público. Nos textos, menção ao Ano Polar Internacional e explicações científicas mais coordenadas com os documentos divulgados pelas instituições científicas. Na FIG. 4.3, a capa da edição 2003.

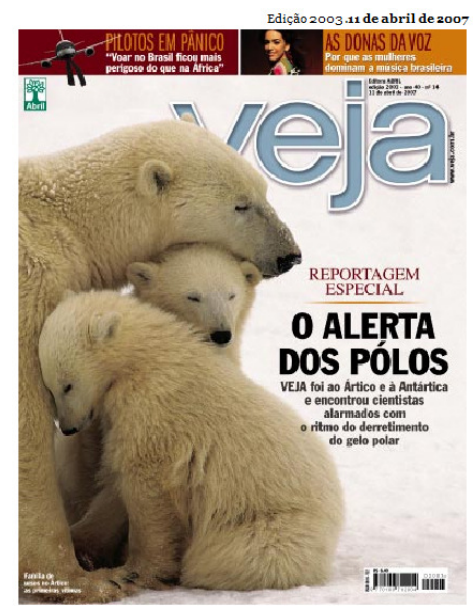

FIGURA 4.3 - Capa da revista Veja de 11/04/2007

Fonte - http://veja.abril.com.br/idade/exclusivo/110407/capa.htm

A reportagem intitulada "Explosão criativa" afirmava que "o aquecimento global pode obrigar o homem a viver nos pólos. Seria uma volta ao gelo, onde nasceu a cultura humana". Alguns dos trechos das reportagens:

"O que se ouve nos pólos agora é, infelizmente, um grito agônico".

"As crianças de hoje serão testemunhas dessa mudança brutal e talvez não possam ver ursos-polares fora de zoológicos".

"Foi no clima rigoroso da última glaciação na Europa, que só terminou 11.500 anos atrás, que o homem moderno desenvolveu os conceitos de família, de religião e de convivência social, os alicerces da civilização atual." 
Alguns conceitos científicos foram melhor explicados, de forma simples, e os erros detectados no ano anterior foram menos incidentes, possivelmente pela ampla discussão do tema, mais disseminado pelos meios de comunicação.

$\mathrm{Na}$ reportagem especial de 11/04 "Todo mundo quer ajudar a refrescar o planeta" foi apresentada ressalva a respeito do risco da discussão sobre aquecimento global encobrir a degradação ambiental de modo geral. As ameaças ambientais mais sérias foram tratadas como pragas apocalípticas.

"O risco embutido na "moda" do aquecimento global é desviar a atenção de outra ameaça ambiental igualmente grave e cujas conseqüências se farão sentir mais cedo: o esgotamento dos recursos naturais do planeta."

"Em 1798, o economista inglês Thomas Malthus afirmou que as guerras pela disputa de comida dizimariam populações inteiras. A fome seria provocada por um descompasso entre o crescimento vertiginoso da população e a produção de alimentos. Em 1962, a bióloga Rachel Carson anunciou que o uso intensivo de pesticidas provocaria um desastre ecológico. A explicação era que o DDT e outras substâncias, que permanecem no ambiente por muitos anos e se acumulam nos tecidos gordurosos, têm efeitos nocivos em animais e seres humanos. Essas e outras pragas apocalípticas foram vencidas. Disse a VEJA o climatologista Richard Lindzen, do Instituto de Tecnologia de Massachusetts: "O homem sempre foi capaz de se adaptar ao ambiente. Ele inventou as casas, o guarda-chuva, a calefação e a substituição de colheitas. Desta vez, com o aquecimento global, não será diferente".

"A exploração dos recursos naturais permitiu ao ser humano atingir no século XX níveis de conforto inéditos em sua história. Mas os especialistas em políticas ambientais advertem que é urgente coibir o desperdício, principalmente diante do rápido desenvolvimento da China e da India. Se essas duas nações, que abrigam um terço da população do globo, alcançarem patamares de consumo iguais aos de uma região rica como a Califórnia, os recursos naturais do planeta entrarão em colapso".

A reportagem de 25/04/2007, "O guardião da atmosfera", traz entrevista com Frank Rowland, Nobel de Química em 1995, que "descobriu os danos ao ozônio e agora luta contra o aquecimento global”, como anunciado no entretítulo. Uma imprecisão foi apontar os danos ao ozônio e não à camada de ozônio. Porém uma das contribuições do texto pode ser percebida no exemplo a seguir, quando Rowland mostrou como apenas um evento afeta todo outro complexo de sistemas e como se inserem as incertezas na ciência. Alguns detalhes escapam aos modelos, por serem muito específicos, mas não os inviabilizam. $O$ fato de os leitores poderem acessar um texto leve e rico em histórias ajuda a entender no geral o problema. 
"Os problemas que estão por vir são imprevisíveis. Vou dar um exemplo: o abeto-vermelho (árvore conífera rica na produção de resina, comum nas florestas temperadas) tem crescido por séculos em Kenai, península do sul do Alasca. As árvores começaram a ser atacadas por um tipo de inseto. Isso se tornou um problema, mas nunca havia chegado a ponto de ser uma ameaça maior, porque boa parte dos insetos morria nos meses mais frios. Quando o Alasca começou a esquentar um pouco mais, os escaravelhos deixaram de morrer no inverno e eliminaram completamente as árvores de abeto. Para que prevíssemos uma conseqüência como essa, precisaríamos de um modelo meteorológico e biológico muito complexo".

Por ocasião do lançamento do terceiro capítulo do quarto relatório do IPCC, a revista publicou reportagem na edição 2007, de 09/05/2007, com o título "Sim, ainda podemos limpar a sujeira". Apresentou dados sobre o custo de se combater o aquecimento global e no final ressaltou que não se deve tirar da leitura do terceiro relatório do IPCC a conclusão de que é fácil controlar o efeito estufa (no caso, seu incremento).

"Para a obtenção de resultados significativos nos níveis de gases poluentes na atmosfera, o esforço de redução das emissões precisa ser global. $O$ fracasso do Tratado de Kioto, ao qual os Estados Unidos, os maiores emissores de CO2 do mundo, não aderiram, ilustra os problemas colocados diante das tentativas de conter o aquecimento global."

A edição 2010, de 30/05/2007 - edição especial Veja Mulher - trouxe 20 maneiras de ajudar o planeta e listou hábitos que implicam em economia e reduzem o consumo.

$\mathrm{Na}$ edição 2011, de 6/06/2007, foram apresentadas seis ideias para uma moradia ecológica.

"É um conceito do século XXI, a era do aquecimento global, em que a questão ambiental deixou de estar circunscrita às rodas de ecologistas para ocupar as pranchetas de arquitetos em países da Europa e nos Estados Unidos"

$\mathrm{Na}$ edição 2014, de 27/06/2007, foi publicada reportagem "O aquecimento global já afeta a qualidade do vinho". Com a elevação das temperaturas, houve um novo desenho do mapa da produção de vinho. Um estudo mostrou que em 27 regiões produtoras de vinho o aumento de temperatura deve ser, em média, de $2^{\circ} \mathrm{C}$ até 2049.

"Além do aumento das temperaturas, regiões produtoras tradicionais podem enfrentar também secas mais intensas e prolongadas. A alternativa para enfrentá-las seria a irrigação - com o conseqüente aumento de custos, em especial na Europa."

$\mathrm{Na}$ edição 2019, de 01/08/2007, "Aquecimento nas alturas" tratou do encolhimento das geleiras do Himalaia, colocando em risco a população de cinco 
países da Ásia. Em um quadro, comentários sobre temporais na Inglaterra que ocorreram na época. Percebe-se o cuidado na narrativa com essa ressalva:

"A relação direta entre o aquecimento global e eventos tão extremos como os temporais na Inglaterra ainda é incerta. Um estudo publicado na revista Nature, na semana passada, mostrou que o nível de chuva em algumas partes do mundo, entre elas a Inglaterra, aumentou nos últimos oitenta anos por causa, em grande medida, da emissão de gases do efeito estufa. Mas o estudo não prova a ligação de episódios únicos e extremos com as alterações no clima do planeta. Os temporais nas cidades inglesas podem estar mais ligados a pequenas variações climáticas regionais, ainda difíceis de medir."

$\mathrm{Na}$ edição 2024, de 05/09/2007, o então embaixador americano no Brasil comentou a postura do governo norte-americano frente a ameaça climática.

\begin{abstract}
"Veja - Por que o governo Bush demorou tanto tempo para admitir que o aquecimento global é uma realidade e que ele pode representar uma ameaça às economias de muitos países?

Sobel - Não acho que a administração Bush tenha mudado de opinião de uma hora para a outra. Foi um processo em etapas. De qualquer modo, hoje o presidente Bush está comprometido com a luta contra o aquecimento global, juntamente com outros países."
\end{abstract}

Outras citações e entrevistas trouxeram abordagens sobre a questão climática, mas a edição 2027, de 26/09/2007, trouxe uma visão diferente dos impactos do aquecimento do planeta. Sob o título "Ouro sob o gelo", a reportagem apresentou "um impacto inesperado do aquecimento global: o início de uma nova era de exploração das riquezas do Ártico". O texto abordou a possibilidade de exploração da região, com o aquecimento global, "uma boa notícia para os negócios", embora seja "devastador para a fauna" da região. Uma abordagem que contraria os preceitos de um ambiente equilibrado com boas condições para as gerações futuras. Não cabe a conceituação como bom negócio. Os argumentos e dados do estudo citado na reportagem foram apresentados de maneira breve, a seguir.

"O aquecimento global - e o conseqüente recuo das geleiras - desencadeou uma nova era de exploração no Ártico.

Um estudo estima que a região pode conter $25 \%$ de todas as reservas de petróleo ainda desconhecidas. Com o preço do gás e do petróleo nas alturas, começou a valer a pena enfrentar as dificuldades da prospecção sob frio intenso. Naturalmente, a disputa política pelo controle do extremo norte tornou-se acirrada.(...)

(...) Boa notícia para os negócios, as mudanças são devastadoras para a fauna. De acordo com um estudo, com a redução de seu habitat, em 2050 a população de ursos-polares estará reduzida a um terço da atual." 
Na edição 2028, de 3/10/2007, um quadro relacionado à reportagem "O avanço das algas tóxicas" mostrou uma proposta do cientista inglês James Lovelock de aumentar a quantidade de fitoplâncton na superfície dos oceanos, por meio de um sistema de engenharia, trazendo águas a 200 metros de profundidade (mais ricas em nutrientes) para a superfície. A decomposição da algas seria agente facilitador do processo de formação de nuvens, que ajudam a reduzir o aquecimento, por sua capacidade de refletir a luz solar.

O papel dos biocombustíveis no combate ao aquecimento global apareceu em algumas citações e foi objeto de comentário na seção carta do leitor de 10/10/2007.

Na edição 2031, de 24/10/2007, o tema mereceu reportagem de capa ("Salvar a Terra"), com o título "Países e pessoas agem... mas alguns ainda duvidam". A abertura da reportagem se assemelhou a um roteiro de cinema:

"Em que planeta vivemos? Se for no planeta Al Gore, estamos em apuros. Um brasileiro que nasça hoje chegará à idade adulta em um mundo hostil e diferente, no qual restarão raros ursos-polares fora do zoológico e se poderá navegar pelas ruas do Recife, submersas pela elevação do nível do mar. Seus netos viverão num ambiente pestilento, com surtos de malária, dengue e febre amarela decorrentes do clima mais quente. Na Amazônia, com temperaturas 8 graus mais altas que as atuais, a floresta se transformaria em cerrado e estaria sujeita a incêndios de dimensões bíblicas. O que se chama aqui de planeta Al Gore é aquele que o político americano descreveu em seu documentário Uma Verdade Inconveniente, cuja drama-ticidade Ihe rendeu dois dos prêmios mais cobiçados que existem. O primeiro foi o Oscar, entregue em fevereiro. O segundo é o Nobel da Paz de 2007, que ele receberá no dia 10 de dezembro em Oslo, ao lado do indiano Rajendra Pachauri, presidente do Painel Intergovernamental Sobre Mudanças Climáticas das Nações Unidas (IPCC). Mas será que a Terra só tem como futuro se transformar no planeta Al Gore? Talvez não."

O texto da revista também marcou uma realidade que se pode constatar na análise da cobertura de imprensa, de que a luta contra 0 aquecimento global se tornou quase que uma doutrina e também instrumento nas mãos dos políticos. No texto, as mudanças climáticas foram descritas como "a maior religião urbana de alcance planetário de que se tem notícia". Também foram listadas as divergências entre os chamados "ambientalistas ortodoxos" e os "céticos".

$\mathrm{Na}$ reportagem afirmou-se que "seria excelente se as respostas para todas essas divergências pudessem ser encontradas no meio do caminho entre os dois extremos." 
Um quadro comparativo entre o que dizem os relatórios do IPCC e o que afirmavam os chamados céticos foi montado e, após comparar os dois discursos, a revista marcou qual o grupo estaria com a razão ou mais próximo disso, comentando que a grande dúvida seria sobre a gravidade dos efeitos das mudanças climáticas. Entretanto, a escolha da coluna sobre quem está certo não parece algo adequado.

Em 18/04, foi publicada carta de leitor da revista, que abordou uma discussão ainda não disseminada suficientemente. O questionamento é vital, mas pouco se faz para combater a degradação ambiental. As iniciativas isoladas, a falta de ações integradas, a demora e inação dos governos, em geral, não é questionada pela população.

"Por um lado comemoramos a venda recorde de automóveis no Brasil e invejamos o crescimento de Índia e China, por outro devemos ver esses fatos como agravantes do efeito estufa. Como vamos conciliar esses desafios? A economia mundial precisa de crescimento constante, que provavelmente em algum momento não será mais possível. Quais são as conseqüências em um mundo com população crescente, mesmo que à força de calor e falta de água?" (Sérgio Marchió, Mineiros, GO)

Na edição 2032, de 31/10, carta de leitor citou que "entre a inércia dos céticos e o zelo dos ortodoxos, as gerações futuras herdarão um planeta melhor se ouvirmos os conselhos dos segundos." (Vanessa C. Santos- Petrópolis, RJ)

$\mathrm{Na}$ Revista Época em 2007, foram 14 edições contendo algum texto sobre mudanças climáticas.

Na edição 450, de 01/01/2007, a reportagem "Salve o planeta" abordou o poder de compra e a consciência ambiental dos consumidores fazendo a diferença. Escolha bem seu carro, dê carona, use o sol, escolha aparelhos mais econômicos e reduza o consumo, aproveite o vento (sinalizando para energias limpas) e vote verde (ou escolha candidatos com propostas em prol do ambiente) foram alguns dos conselhos para os leitores. O uso da interatividade também foi uma ferramenta utilizada no texto, ao recomendar o download de uma cartilha sobre o efeito estufa.

Em 2007, a revista Época continuou com o tom de alerta para o aquecimento global, volta a abordar as pequenas mudanças de hábitos de consumo (edição 454, de 29/01/2007) e anotou uma situação "pior do que imaginávamos" demonstrada no relatório do IPCC. A FIG. 4.4 reproduz a edição 
454, que apresentou uma capa negra e remeteu os leitores a uma situação apocalíptica, com o título "O mundo vai acabar?".

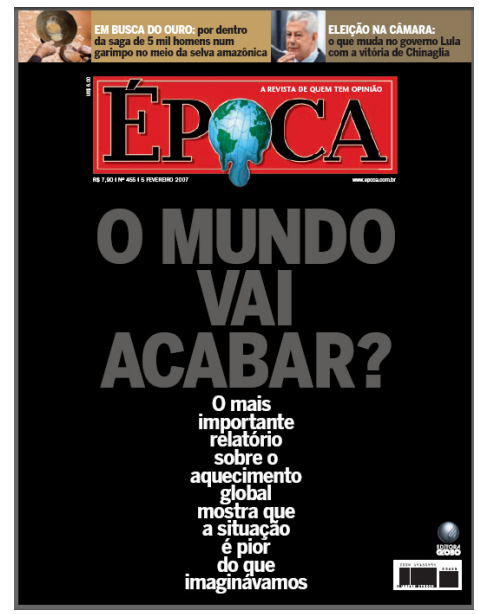

FIGURA 4.4 - Capa da revista Época de 05/02/2007

Fonte - http://veja.abril.com.br/idade/exclusivo/110407/capa.htm

A edição 457, de 19/02/2007, trouxe o título de reportagem "Catástrofe quase todo ano". O apelo continuou na edição 460, de 12/03/2007, com a reportagem "Em nome dos nossos filhos", sobre a necessidade de ações em prol das futuras gerações, a partir de entrevista com o climatologista norte-americano Ralph Cicerone. Um trecho sobre a opção nuclear foi transcrito a seguir, com detalhe para o texto contendo imprecisão técnica sobre explosão de usina nuclear, ao não especificar que uma possível explosão seria de natureza química (resultante de uma bolha de hidrogênio) e não nuclear. Porém o conceito ou ideia central - de perigo, risco extremo - foi compreendido.

"Época - O senhor é a favor do uso de energia nuclear?

Cicerone - Vamos precisar dela.

Época - E não é perigoso?

Cicerone - Sim, é. Mas podemos fazer usinas que não sofram explosão. $O$ lixo atômico, porém, continua um problema.

ÉPOCA - Essas "pequenas mudanças podem resolver o problema ou só adiá-lo?

Cicerone - Não sei, mas adiar já é válido. Porque há idéias de soluções a longo prazo, como energia a fusão nuclear, uma forma mais segura de energia nuclear. Isso deverá ser realidade em 30 ou 40 anos."

(Revista Época, 19/02/2007 - “Em nome dos nossos filhos")

Na edição 463, a foto de capa mostrou a elevação do nível do mar com impacto no RJ. Em primeiro plano, o monumento do Cristo Redentor, cartão 
postal da cidade. O título "Isto pode acontecer" foi chamada para reportagens que procuraram mostrar como o aquecimento global vai afetar o Brasil e as medidas necessárias para mitigar seus impactos negativos. Novamente, dos gases de efeito estufa o gás carbônico teve abordagem principal e as fontes dos GEE não foram mencionadas de forma mais completa. Chamam atenção os mapas, infográficos e a qualidade visual do material apresentado. Na Amazônia, no Nordeste, no litoral, o impacto das secas e inundações para diferentes culturas agrícolas, entre outros itens, foram ilustrados e descritos em forma de tópicos, de leitura mais imediata. A reportagem ouviu 12 cientistas como fontes de informação.

A edição 464, de 9/04/2007, "As ameaças para o planeta" apresentou a cobertura sobre os resultados apresentados em Bruxelas, Bélgica, por ocasião da divulgação do segundo capítulo do AR4, apontando possíveis consequências do aquecimento global em todo o mundo. No texto, o protocolo de Quioto mereceu espaço reduzido, com uma referência mais geral.

$\mathrm{Na}$ edição 483, de 20/08/2007, a referência a uma mudança nos valores de registro da temperatura média dos EUA desde 1880, pela NASA. A revisão alterou uma tabela dos anos mais quentes registrados naquele país. A forma pouco transparente pela qual a instituição lidou com o erro foi atacada. $O$ ano mais quente registrado até então passou a ser 1934, no lugar de 1998, e o erro de cálculo passou a ser um ponto a explorar pelos que negam o aquecimento global. Na publicação, a história ganhou o título "Um debate acalorado". A forma de apresentar a história, repercutindo inclusive com pesquisador brasileiro foi interessante.

$\mathrm{Na}$ edição 490, de 8/10/2007, em uma entrevista, o economista dinamarquês Bjorn Lomborg afirmou não estar claro se o aquecimento global seria mais grave que outras ameaças. Sugeriu focar a pesquisa em tecnologias limpas para combater o problema. E arriscou dizer que fazer promessas cada vez maiores não seria o caminho.

"Os países desenvolvidos se comprometeram a chegar ao ano 2000 com os níveis de emissões de 1990 e ficaram 12\% acima disso. Em 1997, o compromisso foi ficar 5\% abaixo dos níveis de 1990 e nós provavelmente ficaremos $20 \%$ acima. Essencialmente, o que nós fizemos foi repetidamente prometer cada vez mais e fazer cada vez menos" 
Na mesma edição 490, a reportagem " $R \$ 7$ bilhões para salvar a Amazônia" tratou do desmatamento e investimento na exploração sustentável da região, com informação de qualidade e relacionando à problemática das mudanças climáticas. Um quadro sobre o aquecimento global, contribuição por setor e detalhamento sobre as regiões afetadas pelo desmatamento permitiram formar uma das melhores reportagens do período analisado. Os dados apresentados permitiram uma posição bastante completa do que então ocorria com a região.

$\mathrm{Na}$ edição 498, de 3/10/2007, "O Brasil na retranca" se propôs a mostrar por que o país não iria brilhar na convenção mundial do clima. A frase do coordenador da área de mudanças climáticas do Ministério do Meio Ambiente, Gonzalez Miguez, de que "o combate às mudanças climáticas não pode atrapalhar o desenvolvimento econômico", apresentou uma visão equivocada. No texto essa ideia foi desenvolvida e em uma frase foi apresentada posição crítica. Mais adiante, a contra-argumentação baseando-se na citação aos dados do Imazon e Banco Mundial.

"Embora compreensível, o discurso oficial do país se baseia na falsa premissa de que existe uma oposição entre desenvolvimento e preservação. De acordo com estudos do Instituto do Homem e Meio Ambiente da Amazônia (Imazon) com o Banco Mundial, as cidades mais desmatadas são também as mais pobres da Amazônia."

O acompanhamento da conferência pela internet e artigos de participantes ficaram disponíveis aos leitores. No texto, uma referência ao material.

A edição 499, de 10/12/2007, trouxe reportagem explicando as negociações em Bali, Indonésia, pelos compromissos de cortes de emissões nos próximos anos, no período posterior à vigência do Protocolo de Quioto. Artigos de especialistas também foram anunciados para leitura na internet.

$\mathrm{Na}$ edição seguinte, de número 500, 17/12/2007, um resumo do que trouxe a conferência do clima em termos de resoluções. "A agenda está pronta" sintetizou aspectos negociados em Bali e outros necessários para os anos seguintes, voltados ao novo compromisso internacional de controle das emissões, em substituição ao Protocolo de Quioto. 


\subsubsection{Resumo geral}

Nas FIG. 4.5 e 4.6 estão demonstradas, de forma resumida, as abordagens do tema nas editorias Vida \& (OESP) e Ciência (FSP), com os seguintes temas predominantes: política, pesquisas sobre mudanças climáticas, enfrentamento das mudanças climáticas e consequências das mudanças climáticas.

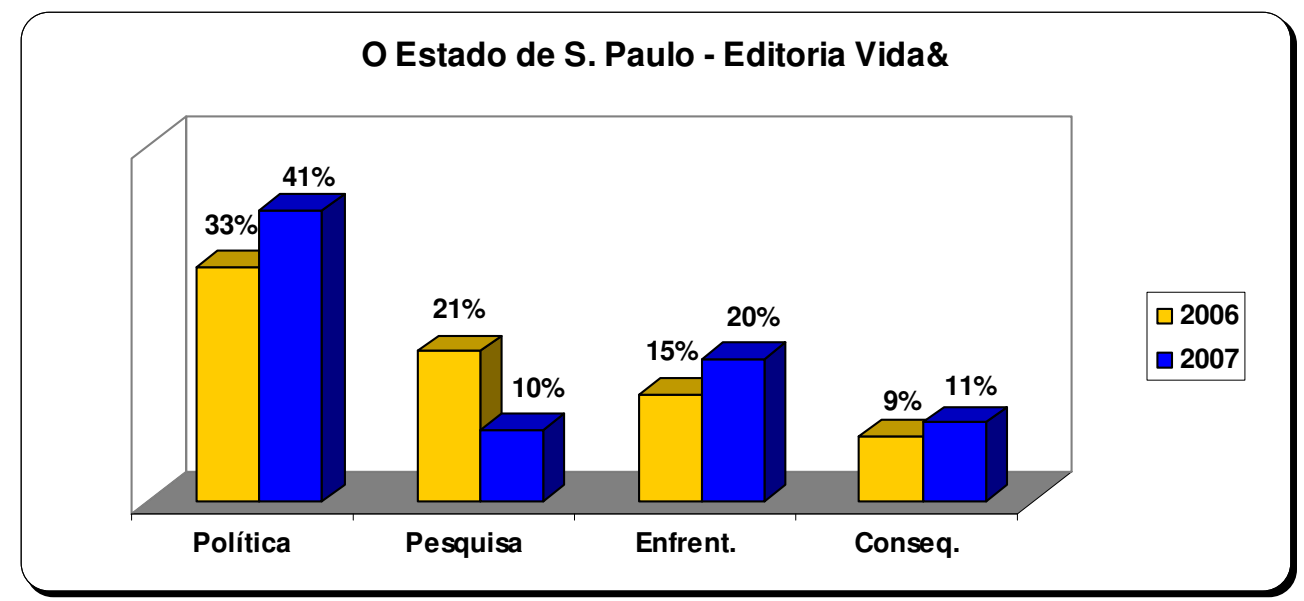

FIGURA 4.5- Textos da editoria Vida\& (OESP) - anos de 2006 e 2007 Fonte - Elaborada pela autora

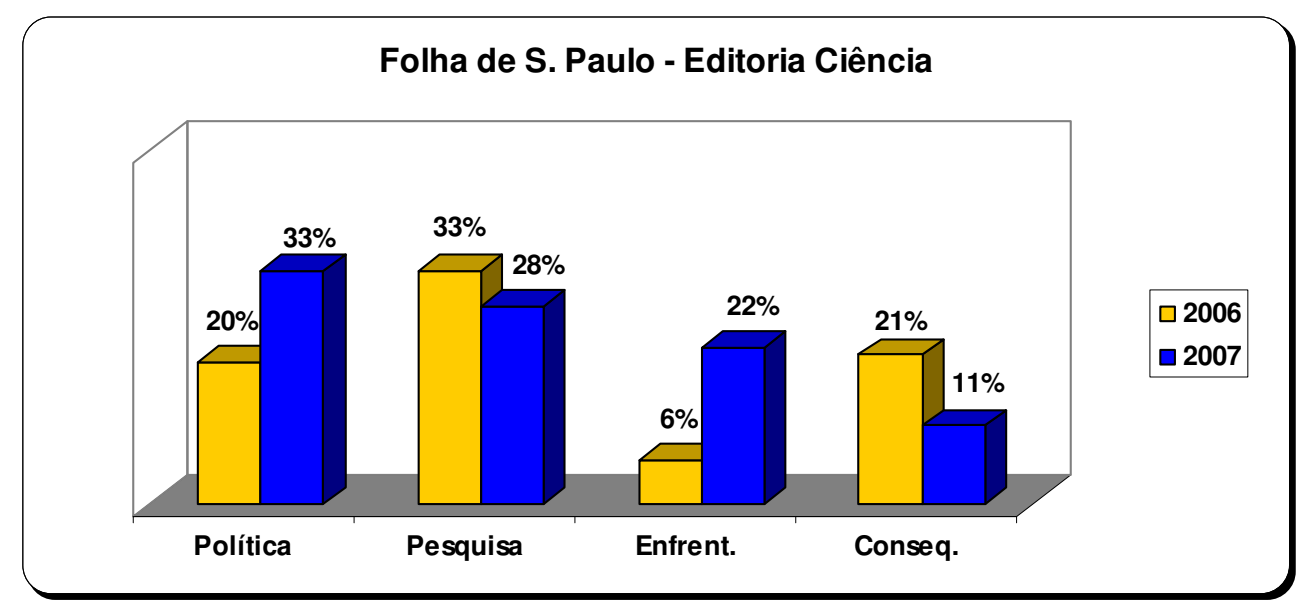

FIGURA 4.6 - Textos da editoria Ciência (FSP) - anos de 2006 e 2007 Fonte - Elaborada pela autora

Em relação aos textos dos dois jornais analisados nos anos de 2006 e 2007, na FIG. 4.7 apresenta-se em que editoria foram publicados. 


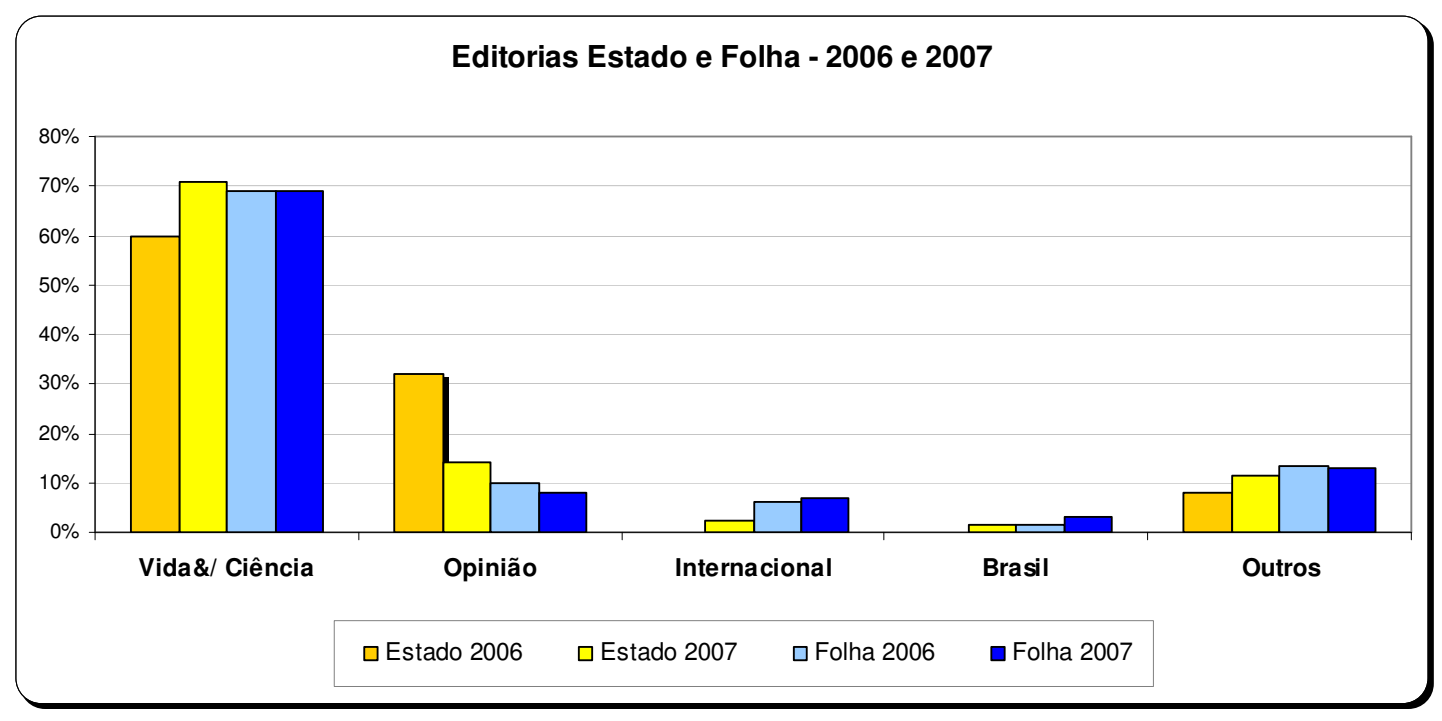

FIGURA 4.7- Textos publicados em 2006 e 2007 - principais editorias Fonte - Elaborada pela autora

\subsection{Pesquisa de campo}

A pesquisa de campo pode se utilizar de questionário ou entrevista junto aos elementos envolvidos. Permite análise e conclusões segundo objetivos previamente estabelecidos (Parra e Santos, 1998).

Após pesquisas preliminares, foi possível elaborar questionários voltados à coleta de dados sobre a experiência de cientistas, jornalistas e do público no que diz respeito a abordagem de mudanças climáticas como um assunto que ocupa a pauta nacional no jornalismo ambiental, permitindo ainda discutir temas como divulgação científica e a assimilação de conteúdos por parte do público em um mundo cada vez mais fragmentado.

\subsubsection{Questionamento aos cientistas}

Reunir informações de cientistas a respeito da relação jornalismo e ciência possibilita melhor compreender as limitações e pensar estratégias que contribuam para que o público receba informação de qualidade. Ao mesmo tempo, isso só pode ser obtido se jornalistas, cientistas e formuladores de políticas não perderem de vista o maior objetivo de todo o trabalho realizado: a sociedade.

A partir do levantamento bibliográfico realizado, foram elaboradas algumas questões para serem respondidas por cientistas que desenvolvem 
pesquisas relacionadas a mudanças climáticas globais, de diferentes áreas. Os pesquisadores entrevistados têm experiência no contato com a mídia, pois foram fontes de várias reportagens em órgãos da grande imprensa. Todos já atuaram como redatores ou revisores do IPCC. Responderam a um questionário (APÊNDICE C), com o objetivo de aferir sua percepção a respeito do contato com jornalistas e a apresentação do tema mudanças climáticas ao grande público:

- Carlos Afonso Nobre, Pesquisador Titular do INPE, Chefe do Centro de Ciência do Sistema Terrestre. Membro do IPCC. Presidente do Conselho Diretor do Painel Brasileiro de Mudanças Climáticas. Tem experiência na área de Geociências, com ênfase em Meteorologia, atuando principalmente nos seguintes temas: ciências atmosféricas, clima, meteorologia, Amazônia e modelagem climática, interação biosfera-atmosfera e desastres naturais (LATTES, on line ${ }^{20}$ ).

- José Antonio Marengo, Pesquisador Titular do INPE, Chefe da Divisão de Sistemas Naturais do Centro de Ciência do Sistema Terrestre. Membro do IPCC. Tem experiência na área de Geociências, com ênfase em Meteorologia, atuando principalmente nos seguintes temas: Amazônia, clima, mudança de clima e modelagem de clima (LATTES, on line ${ }^{21}$ ).

- Paulo Eduardo Artaxo Netto, Professor Titular do Instituto de Física da USP, Chefe do Departamento de Física Aplicada da USP. É membro do IPCC. Trabalha com física aplicada a problemas ambientais, atuando principalmente nas questões de mudanças climáticas globais, meio ambiente na Amazônia, física de aerossóis atmosféricos, poluição do ar urbana e outros temas (LATTES, on line ${ }^{22}$ ).

- Pedro Leite da Silva Dias, Professor do Instituto de Astronomia e Geofísica da USP, Diretor do LNCC/ MCT. Foi membro do IPCC (1993-1995 e 2004-2006). Suas áreas de especialização são: dinâmica da interação trópicos/extratrópicos, com ênfase no

\footnotetext{
${ }^{20}$ http://lattes.cnpq.br/1608252203113404

${ }^{21}$ http://lattes.cnpq.br/5719239270509869

22 http://lattes.cnpq.br/3977660018939385
} 
papel das fontes de calor associadas à precipitação através de estudos observacionais e de modelagem numérica; aplicações numéricas e práticas em procedimentos operacionais de previsão de tempo; experiência também em questões de variabilidade climática, mudanças climáticas e impacto ambiental (LATTES, on line $\left.{ }^{23}\right)$.

- Thelma Krug, Pesquisadora do INPE, Chefe da Cooperação Internacional. Membro do IPCC. Tem experiência na área de Probabilidade e Estatística, com ênfase em Probabilidade e Estatística Aplicadas. Suas linhas de pesquisa são emissões de gases de efeito estufa oriundas de atividades de mudança de uso da terra e emissões de gases de efeito estufa por queima de biomassa no cerrado não antropizado (LATTES, on line ${ }^{24}$ ).

Optou-se por apresentar as respostas obtidas sem, entretanto, identificar o respondente. A primeira pergunta aos pesquisadores foi:

"Como você avalia a compreensão das pesquisas relacionadas ao tema mudanças climáticas por parte da imprensa?"

Foi abordada a dificuldade dos cientistas em se fazerem compreender pelo público em geral. E fica clara a importância dessa aproximação na visão dos pesquisadores, como na resposta a seguir:

"Certamente a ciência precisa de um grande esforço em se fazer chegar ao grande público e às mídias".

Foi apontada por um dos pesquisadores a dificuldade dos jornalistas em formularem questões relevantes do ponto de vista científico. Por outro lado, também foi registrado que os jornalistas estão cada vez mais cientes do assunto. Há maior compreensão do assunto mudanças climáticas pelos jornalistas em relação ao início dos anos 90, quando o tema passou a ter mais visibilidade, segundo um dos entrevistados. "Hoje é muito mais fácil comunicar ao profissional da imprensa os conceitos fundamentais associados ao tema". Segundo o mesmo entrevistado, a maior dificuldade é passar a mensagem referente às incertezas

23 http://lattes.cnpq.br/9273702863744424

24 http://lattes.cnpq.br/9273702863744424 
científicas quanto ao tema. Mas isto não ocorre só neste tema, completa. "O tratamento da incerteza científica passa por conceitos complexos".

Uma observação bastante pertinente é feita por outro entrevistado, de que jornalistas especializados em ciência têm bom conhecimento sobre o tema e entendem bem. Jornalistas de outras áreas em geral não entendem sobre o tema o suficiente e produzem matérias superficiais, segundo o mesmo respondente. Uma das respostas indica que a imprensa, de modo geral, tem feito uma "cobertura razoável do tema", sem muita distorção. Para outro entrevistado, há exagerado sensacionalismo da imprensa, tanto nacional quanto internacional.

A pergunta seguinte foi: "Houve mudança com relação ao entendimento dos temas por parte da imprensa desde a divulgação do último relatório do Painel Intergovernamental sobre Mudanças Climáticas (IPCC)? De que forma?

Todos concordaram que AR4 foi fundamental no processo de divulgação do tema, como que um divisor de águas. Antes disso, o tema era "fundamentalmente restrito à grande imprensa". Após a divulgação, houve o despertar de interesse para o assunto por parte de veículos de setores específicos, como por exemplo órgãos de imprensa de sindicatos e entidades de classe, lembrou outro entrevistado. Outra resposta destaca que pesquisadores brasileiros envolvidos na elaboração do quarto relatório de avaliação do IPCC se empenharam mais para divulgar os resultados científicos, respondendo a uma estratégia do próprio órgão. E indica ainda que o conhecimento da mídia sobre o tema melhorou, mas ainda seria insuficiente para uma visão mais crítica do trabalho do IPCC. Outra resposta reflete que o entendimento dos jornalistas vem aumentando gradativamente.

Uma das respostas indica que embora o assunto seja mais abordado, o entendimento das questões científicas não sofreu alteração. Prossegue apontando a dificuldade do tema, que envolve alta complexidade e multidisciplinaridade das questões associadas às mudanças globais. A cobertura sensacionalista foi apontada como um problema. O interesse do público em geral e dos tomadores de decisão é grande e a imprensa não faria seu trabalho de divulgação a contento. "Às vezes gera mais dúvida do que esclarecimento".

Para outro participante, o tema mudanças climáticas passou a ser discutido regularmente pela imprensa, com entendimento cada vez melhor por 
parte dos jornalistas. E a imprensa cobre assuntos relevantes como desmatamento, queima de combustível fóssil, desastres naturais de origem climática, entre outros.

A pergunta seguinte foi: "Destacaria alguma reportagem com a qual colaborou como fonte de informação e que tenha chamado sua atenção por ter sido um exemplo diferenciado na cobertura do tema mudanças climáticas?"

Foram citados um caderno especial da Folha de S. Paulo, na época de divulgação do AR4, que contou com contribuições de pesquisadores brasileiros, e outros cadernos publicados pelos jornais $\mathrm{O}$ Estado de S. Paulo e O Globo, no mesmo período. O INPE também divulgou seu relatório do clima e colaborou com material e dados para as reportagens. Uma revista do setor sucroalcooleiro, Opiniões, foi citada como exemplo. Foram três citações para a Folha, duas para O Estado de S. Paulo, duas para o jornal O Globo e uma para a revista Pesquisa Fapesp como exemplos de veículos que apresentaram reportagens diferenciadas. Como a pergunta procurou algum exemplo para o qual o pesquisador tenha sido fonte de informação, a resposta apresentou alguma limitação. Uma dos respondentes não registrou exemplo específico. A conclusão a que se pode chegar é que o material produzido pelos principais jornais foi positivo, especialmente quando contou com a colaboração dos próprios pesquisadores escrevendo artigos ou em entrevistas mais pormenorizadas, com mais espaço para comentários e detalhamento dos temas por parte dos cientistas.

Para identificar como os pesquisadores percebem o domínio de conteúdos por parte dos jornalistas foi formulada a seguinte pergunta:

"No contato com os jornalistas, consegue perceber alguma deficiência no entendimento de conceitos ligados ao tema mudanças climáticas ou no entendimento do conteúdo de pesquisas científicas que pautam as entrevistas?"

Todos apontaram deficiências, sendo que uma das respostas listou temas mais complicados na cobertura, outra destacou problemas inclusive no entendimento de conceitos fundamentais (conceitos básicos sobre 0 funcionamento do sistema climático, a física elementar do efeito estufa), outra indica que as deficiências são menores do que antes da divulgação do AR4 e explicou que alguns entrevistadores ainda têm dificuldades com a diferença entre gases poluidores e gases de efeito estufa. Também foi indicada em outra 
resposta a falta de tempo na preparação das pautas e na captação de informação como um aspecto importante.

Uma das respostas apontou como temas mais complicados:

- a construção de cenários de mudança do clima;

- a indicação de que os impactos a mudança do clima podem ser evitados com ações intensas de mitigação e adaptação;

- o papel das florestas na mitigação da mudança do clima;

- a associação de eventos extremos com mudanças do clima quando isso é impossível de ser feito, já que alguns eventos refletem a variabilidade climática natural e não decorrem necessariamente da mudança do clima.

Uma das respostas sinaliza que muitos jornalistas não entendem do assunto e pode-se passar um tempo considerável explicando os conceitos básicos do clima e ainda assim são publicados erros.

Quando perguntados com que frequência percebem deficiência no entendimento de conceitos ligados ao tema mudanças climáticas ou no entendimento do conteúdo de pesquisas científicas que pautam as entrevistas, quatro pesquisadores responderam na maioria das vezes. Uma das respostas apenas considera que raramente são percebidas tais deficiências.

Para a questão "Quais dos seguintes pontos positivos você percebe no contato com os jornalistas que cobrem ciência e meio ambiente", as opções, com o respectivo registro de respostas, foram:

- leitura prévia do tema tratado em papers e acesso a informações científicas -2 respostas;

- entendimento dos conceitos - 1 resposta;

- bom nível de informação - 4 respostas;

- abordagens diferenciadas (pontos de vista interessantes e originais) - 1 resposta;

- boa qualidade dos textos publicados - 3 respostas;

- poucos erros relacionados a conceitos técnicos - nenhuma resposta. 
Um dos respondentes assinalou que a alternativa é verdadeira para uns jornalistas e para outros não para todos os itens, exceto o último (poucos erros relacionados a conceitos técnicos).

Ou seja, os pesquisadores ouvidos acreditam que os erros não são poucos, mas também existe um alto grau de concordância de que os textos publicados têm boa qualidade e que é bom o nível de informação dos jornalistas que cobrem ciência e meio ambiente.

Na questão seguinte, a intenção foi identificar se havia, na opinião dos especialistas ouvidos, dificuldades no contato com a imprensa. Pelas respostas, foi possível verificar que a maioria considera que não há dificuldades ou que estas são menores do que anteriormente. Uma das respostas destaca que os jornalistas que cobrem ciência e meio ambiente estão mais preparados e houve, por parte da fonte, aprendizado com relação ao uso de linguagem mais adequada. Algumas ressalvas, entretanto, foram feitas em outro registro:

- Dificuldade natural de tornar temas complexos em simples de serem entendidos, mesmo para aqueles que leem sobre o assunto e tentam aperfeiçoar seus conhecimentos;

- Aquilo que o pesquisador comenta é publicado fora de contexto ou de forma tão sintética que torna difícil a compreensão por parte dos leitores do que realmente se quis dizer;

- Há frustração em dispender tempo considerável para ver refletida na matéria apenas alguns elementos que foram citados e em outro contexto;

- Muitas vezes, por limitação de espaço, a mídia não consegue elaborar um texto com a exatidão que mereceria ter.

Outra resposta apresenta uma questão relevante na discussão sobre o conteúdo do que é publicado: às vezes o repórter liga para confirmar o que deseja publicar. Em oportunidades em que há recusa em confirmar fatos apresentados, a matéria é cancelada ou se procura outro pesquisador para entrevistar.

Foram complementares as respostas à pergunta: "Quais os maiores desafios na cobertura pela imprensa do tema mudanças climáticas?". Todas as observações mostraram que os pesquisadores se interessam em comunicar sobre 
os resultados de pesquisas e que cobram profissionais preparados, bem informados e com bom nível de conhecimento sobre o tema.

As respostas são listadas a seguir e merece ênfase que a preocupação com o tratamento político do assunto também está manifestado nas opiniões.

- Cobrir a questão da incerteza de forma realística.

- Perceber claramente que existem interesses econômicos muito fortes.

- Identificar claramente a distinção entre os cientistas que têm uma ideologia preconcebida e que usam a ciência para comprovar a ideologia daqueles cientistas que colocam claramente onde estão as incertezas.

- O desafio é buscar pluralismo de opiniões, mas com balanço sobre o que a ciência robusta diz a respeito. Se já há um enorme consenso sobre aspectos das mudanças climáticas, a imprensa tem que repercutir este consenso e não simplesmente passar a impressão que há dois lados da questão e ambos merecem o mesmo espaço.

- Não ser alarmista, citando com exatidão a forma como os resultados científicos são gerados, e o que representam.

- Mostrar diferentes cenários com diferentes impactos na sociedade, economia, ambiente.

- Mostrar a existência de soluções que podem acarretar em uma interferência não perigosa no sistema climático.

- Identificar o que é concreto do que é ainda trabalho em andamento, principalmente no âmbito das negociações da Convenção do Clima, entre outros.

- Uma boa pauta, bem estruturada e focada em temas relevantes.

- Uma boa pesquisa do jornalista no tema, com consultas sólidas antes da entrevista.

- Um bom nível de cultura geral do jornalista.

- Honestidade na cobertura, sem conceitos pré-estabelecidos e sem querer colocar respostas ou palavras na boca do entrevistado. 
Também foi enfatizado que muitas vezes jornalistas não entendem do assunto. Outra observação foi relacionada à atenção da imprensa ser mais voltada aos cientistas que evitam chamar atenção sobre as incertezas. Um dos respondentes comenta que o assunto aparece devido a algum extremo de clima, quando há tendência de se atribuir um evento meteorológico isolado à mudança de clima. Argumenta ainda que alguns jornalistas não têm a mínima base acadêmica para entender fenômenos climáticos, têm base de geografia e clima pobres, e isso gera problemas em entender o problema.

Quando solicitados a apontar um ou mais exemplos de erros encontrados na cobertura do tema mudanças climáticas, os especialistas ouvidos listaram os seguintes equívocos:

- Conceitos errados são comuns.

- Existência de exageros catastróficos.

- Necessidade de buscar vilões e heróis.

- Compreensão parcial das florestas na mitigação da mudança do clima. O próprio papel da conservação das florestas como forma de mitigar a mudança do clima é importante, mas tem que ser melhor contextualizada.

- É comum atribuir extremos climáticos à mudança climática provocada pelo aumento da concentração de gases de efeito estufa. Ainda não se pode dizer com segurança que esses eventos recentes foram provocados pelo aquecimento global. A variabilidade natural é muito grande e ainda é maior do que o efeito da mudança climática. Pode-se dizer que o aumento da frequência é compatível com o que se espera do aquecimento global. Entretanto, a atribuição com segurança não é cientificamente sustentável. Neste sentido, foram dois os cientistas que apontaram tal erro na cobertura.

- Afirmar que terremotos e tsunamis, que são eventos na escala geofísica, são conseqüência do aquecimento global.

- Atribuir aquecimento global a ações humanas exclusivamente.

Em uma das respostas, ficou registrado que seriam tantos erros que 0 respondente não consegue se lembrar de um específico, a não ser uma matéria 
de capa da revista Veja sobre aquecimento global, em que os redatores afirmaram que "a opinião não científica de alguns céticos era a opinião correta cientificamente" em quatro de seus grandes impactos das mudanças climáticas.

A última pergunta pretendia compreender, nas entrevistas, o enfoque dos jornalistas sobre o tema, considerando as seguintes opções:

- Políticas públicas de combate ao aquecimento global;

- catástrofes ou desastres naturais relacionados às alterações climáticas;

- medidas de mitigação e adaptação relacionadas às alterações climáticas;

- dúvidas técnicas envolvendo conceitos básicos relacionados ao tema;

- dúvidas técnicas envolvendo conceitos complexos relacionados a pesquisas sobre o tema;

- participação da sociedade nas discussões sobre o tema;

- abordagem política do tema mudanças climáticas;

- abordagem econômica do tema mudanças climáticas.

Os entrevistados deveriam responder sobre a frequência com que tais temas eram solicitados. Na TAB. 4.5 está relacionada a distribuição das respostas dos especialistas para a questão.

TABELA 4.5 - Respostas dos cientistas sobre temas das entrevistas

\begin{tabular}{|l|c|c|c|}
\hline Temas das entrevistas & Sempre & $\begin{array}{c}\text { Na maioria } \\
\text { das vezes }\end{array}$ & Raramente \\
\hline Políticas públicas de combate ao aquecimento global & 1 & 4 & - \\
\hline $\begin{array}{l}\text { Catástrofes ou desastres naturais relacionados às } \\
\text { alterações climáticas }\end{array}$ & 2 & 3 & 1 \\
\hline $\begin{array}{l}\text { Medidas de mitigação e adaptação relacionadas às } \\
\text { alterações climáticas }\end{array}$ & & 4 & 2 \\
\hline $\begin{array}{l}\text { Dúvidas técnicas envolvendo conceitos básicos } \\
\text { relacionados ao tema }\end{array}$ & 2 & 1 & 3 \\
\hline $\begin{array}{l}\text { Dúvidas técnicas envolvendo conceitos complexos } \\
\text { relacionados a pesquisas sobre o tema }\end{array}$ & 2 & 1 & 3 \\
\hline $\begin{array}{l}\text { Participação da sociedade nas discussões sobre o } \\
\text { tema }\end{array}$ & 1 & 1 & 2 \\
\hline Abordagem política do tema mudanças climáticas & 1 & 3 & 2 \\
\hline Abordagem econômica do tema mudanças climáticas & & & 2 \\
\hline
\end{tabular}

Fonte - Elaborada pela autora 
Os itens que resultaram em maior concordância foram a frequência das questões sobre políticas públicas de combate ao aquecimento global (na maioria das vezes - 4 respostas; sempre - 1 resposta), medidas de mitigação e adaptação às mudanças climáticas (na maioria das vezes - 4 respostas; raramente - 1 resposta) e abordagem política do tema mudanças climáticas (na maioria das vezes - 4 respostas; sempre - 1 resposta). Três pesquisadores consideraram que na maioria das vezes as perguntas versam sobre catástrofes ou desastres relacionados às alterações climáticas e dois consideram que sempre. Em abordagem econômica do tema três pesquisadores consideram a frequência na maioria das vezes e dois marcaram raramente. A participação da sociedade nas discussões é opção assinalada por três pesquisadores como de incidência rara, uma resposta para a alternativa sempre e outra para a alternativa na maioria das vezes.

Raramente surgem dúvidas técnicas envolvendo conceitos complexos relacionados a pesquisas sobre o tema, conforme três respostas e outras duas apontam que sempre surgem tais dúvidas. Para as dúvidas envolvendo conceitos básicos relacionados ao tema, as opiniões estão divididas entre sempre e na maioria das vezes (duas respostas e uma resposta, respectivamente) e duas outras respostas consideram a frequência de tais dúvidas rara. A abordagem econômica do tema é assunto raro para dois pesquisadores e três outros consideram que as perguntas sobre essa abordagem ocorrem na maioria das vezes.

A jornalista Fabíola de Oliveira, em obra publicada sobre o jornalismo de ciência, destaca a necessidade de senso crítico e capacidade de questionamento, necessárias não só ao jornalista que cobre ciência mas aos jornalistas de qualquer outra área. A relação entre cientistas e jornalistas também possui determinadas peculiaridades, de acordo com Oliveira, mas "felizmente é cada vez maior o número de cientistas que têm a consciência sobre a relevância que seu trabalho pode ter para a sociedade" (Oliveira, 2002). A dimensão social desse trabalho e a possibilidade trazida pelo jornalismo científico de transmitir ao público sobre o ofício do cientista é o foco da discussão. O processo de amadurecimento do jornalismo científico é citado pela autora, que aborda vários aspectos dessa relação. Ainda há barreiras a vencer, desafios a superar, mas é fundamental enfrentá-los, já que o resultado do trabalho desenvolvido é a 
participação dos cidadãos no processo de desenvolvimento da ciência e tecnologia e uma contribuição de alto valor para a criação de uma forte cultura científica no país, segundo vários especialistas, professores e pesquisadores. Se o Brasil quer alcançar posição de destaque no cenário mundial certamente não pode prescindir da dedicação de todos os envolvidos nesse processo.

A baixa visitação a centros e museus de ciência - uma realidade no país - e os problemas na educação formal, com a queda na qualidade de ensino em escolas públicas e privadas, retratam um cenário desalentador. $\mathrm{Na}$ multiplicação de faculdades e abertura de universidades a uma velocidade nunca antes experimentada, aferir a qualidade e o senso crítico dos profissionais formados é uma atribuição bastante prejudicada. É necessário um trabalho contínuo e por décadas para que essa situação seja melhor equacionada. Iniciativas diferenciadas sobre ensino de ciências existem apenas de forma isolada; precisariam ser disseminadas, transformando a realidade e permitindo maior participação da sociedade em questões de política científica e tecnológica, com cidadãos mais informados, interessados e cobrando ações governamentais tanto no que diz respeito à $C \& T$ como em políticas ambientais efetivas e transformadoras.

"No Brasil, a aquisição de direitos em nível legal foi uma grande conquista da sociedade e de seus movimentos, mas a democratização do campo socioeconômico ainda tem um longo caminho a ser percorrido, pois são enormes os problemas gerados pela concentração de renda, a precariedade da formação cultural e o difícil acesso à educação formal básica, e a limitada participação política na discussão e definição dos temas de interesse coletivo (Peruzzo, 2003 apud Duarte, 2007)".

Dias considera que "testemunhamos um momento da evolução do conhecimento humano repleto de contradições, interesses e busca de instrumentos teóricos, metodológicos e epistemológicos, que nos conduzam à compreensão dos processos que asseguram a vida na Terra".

"Os desafios para a criação de modelos sustentáveis de vida humana, mais equânimes na justiça e nas benesses, não poderão ser vencidos por cientistas pensando em separado, produzindo sem vinculações, como o que o conhecimento acadêmico fragmentado gerou nos últimos cinqüenta anos. A interdisciplinaridade e a transdisciplinaridade, longe de uma utopia, surgem como uma grande meta, uma exigência natural para a sobrevivência da espécie humana, se ela quiser continuar sua escalada. Acreditamos que, por meio da adoção de uma 
ética global, do resgate e da criação de novos valores humanos, possamos criar as condições essenciais para que isso aconteça. Os humanos precisam somar esforços, saberes e conquistas. Pode ser um sonho, mas as possibilidades existem." (Dias, 2004).

A simplicidade esquecida dos exemplos didáticos pode fazer muito por um texto de ciência. A eficiência em comunicar conceitos mais complexos de forma mais simples só tende a beneficiar jornalistas e público. A formação de todos os profissionais dentro de uma estratégia de ensino utilizando-se ferramentas e metodologias inovadoras é uma ponte sólida na tarefa de proporcionar um processo de comunicação eficiente.

O processo de geração de conhecimento pode ser ousado e criativo. O jornalismo não tem o papel de suprir deficiências no ensino, mas pode contribuir com a mudança de conceitos e tem trazido elementos importantes para a sala de aula, inclusive. Pesquisadores, que tem seu papel na formação de novas gerações de pesquisadores, devem estar atentos também a essa possibilidade.

\subsubsection{Questionamento aos jornalistas}

"Novos conceitos ou descobertas justificam o uso de uma nomenclatura original, como são os casos de ecossistema, transgênico e biomassa, que levaram algum tempo para evoluir da condição de palavrões até virar verbete de dicionário e, depois de um período de cozimento, ilustrar textos jornalísticos." (Trigueiro, 2005).

Foram selecionados jornalistas das publicações analisadas neste estudo e foi realizada uma análise qualitativa das informações coletadas. As respostas contribuíram para traçar um panorama de como estes profissionais, de publicações de amplo alcance, pensam a questão e para reunir sugestões voltadas à obtenção de melhores resultados no que diz respeito a essa cobertura da temática mudanças climáticas, tendo sempre como ponto principal o leitor.

Sobre a participação dos profissionais de imprensa, a descrição consta no capítulo metodologia. Vale ressaltar que todas as opiniões refletem a visão pessoal dos entrevistados e não traduzem a opinião do veículo para o qual 
trabalham. Uma breve exposição sobre a atuação dos profissionais de imprensa é apresentada a seguir.

- Alexandre Mansur - É editor de Ciência e Tecnologia da revista Época. Trabalha na publicação há 10 anos e, como jornalista, desde 1991. Atua como editor há 10 anos e como editor de Época há 5 anos. Conta com dois jornalistas para cobertura de ciência, mas toda a redação está disponível para a cobertura. Cobre mudanças climáticas desde 1991.

- Claudio Monteiro de Almeida Angelo - Repórter especial em Brasília da Folha de S. Paulo, veículo para o qual trabalha há 10 anos. Foi editor de Ciência da Folha por 6 anos, até julho de 2010. Contava com quatro repórteres para a cobertura de ciência. Trabalha como jornalista desde 1995. Foi editor na revista Superinteressante por um ano e meio.

- Reinaldo José Lopes - Editor interino de Ciência da Folha de S. Paulo, veículo para o qual trabalha há 6 anos. Atua como jornalista profissional há 9 anos. Assumiu a editoria como interino em julho de 2010. Conta com quatro repórteres para a cobertura de ciência. Conta também com dois repórteres do jornal on line.

- Herton Escobar - Repórter especial de O Estado de S. Paulo, para o qual trabalha desde 2000. Cobre especificamente temas de ciência há 10 anos, mesmo tempo em que realiza a cobertura da área de meio ambiente. Desde 1988 cobre temas relacionados a mudanças climáticas. O Estado de S. Paulo conta com sete profissionais no caderno Vida - que engloba ciência, tecnologia, meio ambiente e educação - e um editor.

Basicamente, a preparação dos profissionais entrevistados consistiu em muita leitura, entrevistas e participação em seminários e eventos preparatórios para conferências (COP's). ONG's que trabalham a temática ambiental também realizam workshops e eventos preparatórios para as conferências, conforme assinala Herton Escobar. O editor Alexandre Mansur se referiu a um curso que realizou em 1993 sobre política internacional e meio ambiente, no Instituto de Estudos da Religião, no Rio de Janeiro. Não houve treinamento específico ou 
participação em cursos formais para a cobertura sobre mudanças climáticas pelos profissionais entrevistados.

Uma das questões direcionadas aos jornalistas procurou identificar se o profissional assina algum periódico específico voltado ao tema mudanças climáticas ou recebe regularmente informes de instituição científica. Todos leem os trabalhos que saem nas principais revistas científicas (como Science e Nature). Os informes das principais revistas científicas chegam por e-mail. Outras listas como a Climate List foram considerados úteis em períodos em que ocorrem as COP's por exemplo, segundo comentário de Claudio Angelo, "porém na maior parte do tempo só contribui para encher a caixa de e-mails". Outros canais também apontados para o recebimento de informações foram o twitter, blogs, comunicação com pesquisadores (contato direto ou via assessoria). Entre os boletins citados estão Scientific American e Revista Fapesp, além de consultas regulares a revistas como Science, Nature, Geophysical Research Letters. Os serviços de agências internacionais e as reportagens dos principais órgãos de imprensa também são fontes de informação para os jornalistas.

Para a cobertura de mudanças climáticas, todos afirmaram acessar na maioria das vezes papers e relatórios científicos. Para a cobertura de ciência, todos afirmaram sempre acessar papers e relatórios científicos. Também os textos publicados pela imprensa, no Brasil e no exterior, são lidos pelos jornalistas.

“Às vezes dá para fazer a matéria só com uma entrevista rápida. Mas para qualquer outra reportagem um pouco mais elaborada, preciso ver a literatura científica, os trabalhos que já foram publicados”, destaca Escobar.

Nenhum dos jornalistas entrevistados é ligado a qualquer associação nacional ou internacional de jornalismo científico.

A questão "Quais as maiores dificuldades ou facilidades que encontra no contato com os cientistas?" procurou verificar qual a incidência de fatores positivos e negativos nessa relação entre jornalistas e pesquisadores. Pelas respostas, é possível perceber maior interesse dos cientistas querendo divulgar seus resultados, sendo que dois profissionais frisaram que essa mudança de postura parece ter ocorrido nos últimos cinco ou seis anos. Duas respostas destacaram a menor agilidade do pesquisador brasileiro em atender a uma solicitação em relação à agilidade dos cientistas do exterior. Em apenas uma das 
respostas as assessorias foram lembradas, por questionamento específico da entrevistadora, durante o processo de entrevista. Seguem as respostas, que permitem traçar um breve panorama do cenário hoje existente.

- "Não tenho grandes dificuldades; os cientistas são muito bons em explicar os temas. Cientistas brasileiros têm mais dificuldade entender a necessidade da imprensa em termos de agilidade, enquanto cientistas estrangeiros entendem melhor essa dinâmica de redações. Mas isso está mudando muito rápido. Algumas vezes as assessorias de imprensa fazem essa ponte, mas ainda encontra-se em estágio muito inicial o trabalho" (Mansur).

- "Já foi mais difícil. Houve tempo em que cientista não gostava de falar com jornalista. Eles achavam que o jornalista não ia entender sobre a pesquisa. Já ouvi muito cientista dizendo que o público não tinha que saber sobre a pesquisa dele. Acho que essa situação mudou muito. Percebo isso especialmente nos últimos 5 ou 6 anos. Hoje, com freqüência, o cientista liga, procura, querendo falar sobre uma pesquisa, ou tem algo interessante para te passar" (Angelo).

- "Não tenho grandes facilidades ou dificuldades a apontar. Não acho que os pesquisadores sejam fontes diferentes de nenhuma outra fonte de cobertura. Talvez pela Folha ter um nome bom em jornalismo científico, eles [os cientistas] nunca foram muito arredios. Tendo a achar que pelo menos os que entrevisto no Brasil são bastante didáticos. A agilidade do cientista do exterior é um pouquinho maior. Mas não muito maior. No começo dos anos 2000, essa diferença era maior. Hoje é praticamente igual. Acho que os cientistas criaram um pouco mais de cultura de lidar com a mídia" (Lopes).

- "Acho que talvez no início havia uma certa dificuldade; agora não. Mas não sei se é porque os pesquisadores ficaram mais receptivos ou porque já tenho um nome conhecido e então eles me atendem com mais facilidade. Os pesquisadores às vezes não enxergam o benefício da divulgação do trabalho deles. Acham que estão prestando um favor. Eles não veem como algo positivo. Quando é publicada a matéria dizem: "ficou super bacana...", então percebem o impacto positivo que uma divulgação científica pode trazer. Enquanto o cientista que nunca participou de uma reportagem fica um pouco receoso. Percebi alguma mudança ao longo dos anos, mas não sei dizer se é devido ao meu tempo de trabalho ou se foi uma mudança de consciência, de cultura, na postura do pesquisador. Para a cobertura do tema mudanças climáticas você tem uma abertura muito grande. Porque é um tema que está na mídia, é uma discussão global. Quando se trata de um tema mais específico, sem tanta visibilidade, o cientista fica menos à vontade digamos assim - para dar uma entrevista; ele quer saber de laboratório. Mas os grandes temas - células tronco, mudanças climáticas - tem uma abertura muito boa" (Escobar).

Uma crítica importante, apresentada por Angelo, está relacionada ao entendimento do tema da reportagem por parte do repórter e na forma como esse conteúdo é transmitido ao leitor. Sobre as dificuldades do jornalista com relação à 
linguagem utilizada pelo cientista para explicar o assunto, ele afirma que o tempo dedicado à cobertura de ciências contribui para que o profissional supere as dificuldades. "Claro que sempre há um período de adaptação", lembra. Um problema apontado pelo profissional é que, na hora de escrever o texto, "o repórter fica muito preso ao jargão e às vezes o jargão serve de muleta para disfarçar o que o jornalista não entendeu. Então como ele não entendeu, utiliza jargão. Isso é sintomático".

A pergunta final "Qual o maior desafio para a cobertura do tema mudanças climáticas" apresentou respostas muito críticas e percebe-se a preocupação dos profissionais com a abordagem do assunto, de forma que o leitor possa compreender cada vez melhor. A complexidade do tema não é vista pelos profissionais de imprensa como maior do que nenhum outro. Também a consciência sobre os perigos de se cair no sensacionalismo e a importância de se tratar o assunto de forma que ele possa permear várias esferas foram mencionados nas entrevistas, mostrando a reflexão crítica e o bom nível dos jornalistas ouvidos. O espaço para o jornalismo investigativo também foi lembrado em uma das entrevistas. Seguem algumas respostas, para melhor contextualização:

- "No momento o maior desafio é o desinteresse do público. O assunto está em baixa, mas o fenômeno existe e independe de nossa opinião. $\mathrm{O}$ problema está cada vez mais sério. Esse ano fala-se em recorde histórico de temperatura. Segundo aspecto: explicar algo muito complexo, que exige correlações tão complexas (influência das marés; interação biosfera-atmosfera) e que exige atenção para aspectos de associação não tão simples - como por exemplo o consumo e o estilo de vida influenciando as mudanças globais do clima. Terceiro aspecto que pode ser visto também como desafio: lidar com campanhas de desinformação - IPCC estaria em questão pelo vazamento de conteúdo suspeito de e-mails de pesquisadores participantes do painel do clima... Criou-se uma onda com o problema; ele existe mas não põe em dúvida a conclusão principal do IPCC.

É importante lembrar que toda vez que se consegue criar histórias, aproximar o tema das pessoas o resultado é melhor. Um exemplo disso: a revista publicou uma reportagem a partir de um relatório do Banco Mundial. Ficou algo burocrático. Se tivéssemos correlacionado este relatório com o que o Brasil precisa fazer para reduzir emissões ou talvez sobre transporte público na cidade, o metrô para reduzir as distâncias, o que pode representar em uma cidade com São Paulo, por exemplo, o resultado seria muito mais interessante." (Mansur)

- "Esse tema não é mais complexo que nenhum outro. Talvez os jornalistas não estejam maduros o suficiente para fazer as conexões 
necessárias, inserir mudanças climáticas nas outras discussões. A abordagem é que seria o diferencial". (Mansur)

- "Na parte diplomática, de negociações internacionais, [o desafio] é entender como isso funciona, o que é complicadíssimo. $E$ na sequência, transmitir para o leitor de maneira compreensível. É um tema que inclui milhões de variáveis. É preciso entender de química, de correntes oceânicas, ciências atmosféricas, carbono florestal... Ou seja, o assunto mudanças climáticas inclui muitos temas variados de ciência. Para uma pessoa ter uma boa visão de tudo, é um desafio considerável.

Outro desafio é não cair no sensacionalismo, no catastrofismo, de dizer que o mundo vai acabar amanhã. Acho que é um tema sério, urgente, mas vejo muita matéria tratando como se o mundo fosse explodir amanhã. É tentar transmitir a seriedade do problema sem sensacionalismo." (Escobar)

Na resposta de Claudio Angelo, uma pista sobre os problemas de formação na área de ciências de modo geral. Muitos autores, ao abordar o analfabetismo científico, criticam a forma como as ciências são ensinadas nas escolas, em geral, de forma burocrática e pouco criativa, sem correlacionar as disciplinas ao ambiente, à vida cotidiana, às descobertas que exercitam a capacidade de pensar, de agir. Ainda sobre os desafios da cobertura do tema mudanças climáticas pela imprensa:

- "No Brasil, as pessoas não aprenderam a olhar a literatura científica. Pouca gente faz isso. Acham chato, desinteressante. Entre as pessoas que cobrem o assunto - e que são poucas - falta um pouco de transversalidade. Os jornais ainda não incorporaram essa pauta como um assunto transverso, como por exemplo um assunto de economia. Mudanças climáticas ainda é um tema muito restrito, como um assunto de ciência, meio ambiente. Quando na verdade já deixou de ser uma questão ambiental há muito tempo. Entre os maiores desafios, eu diria que esse tema tem que permear mais esferas do que ele tem atualmente permeado". (Angelo)

- "O jornalista não pode cair no reflexo fácil de outros lados. No sentido de por exemplo abrir espaço demais para céticos do clima e pessoas cujos argumentos científicos não são bons, mas por um reflexo jornalístico de ouvir o contraditório você acaba dando espaço para quem não merece espaço. Acho que esse seria um grande desafio. Pensando no leitor, em abordagem, um desafio é você não cair na falácia da sustentabilidade, esse tipo de reportagem sobre trocar as lâmpadas, usar 'eco bags', essas ações que embora sejam importantes do ponto de vista de conscientização, em termos de resolver o problema mudanças climáticas são irrisórias. É importante estar atento e direcionar para o que é importante, que é o cidadão cobrando as ações governamentais e empresariais, pois essas sim vão fazer diferença. Não se pode achar que a atitude individual de pequena escala sem a ação global vai resolver, 
criando uma certa complacência apenas com base na ação individual. Isso é importante do ponto de vista de conscientização". (Lopes)

Ao comentar os desafios do jornalista na cobertura do tema, Escobar apresenta questões muito relevantes:

- "Há um volume muito grande de papers sendo publicados sobre mudanças climáticas. Se você quer que seu veículo tenha uma cobertura diferenciada, você precisa investigar, apurar, ir além do paper. E isso toma tempo. Em resumo, o desafio de cobrir mudanças climáticas é o mesmo desafio de qualquer matéria científica: tornar a ciência compreensível; tornar um assunto complexo, mais acessível". (Escobar)

Os APÊNDICES A e B trazem os modelos de questionário aplicado aos jornalistas e cientistas.

\subsubsection{Questionário destinado ao público}

No primeiro semestre de 2010, 108 voluntários do público em geral responderam a um questionário constituído por 11 perguntas, em sua maior parte abertas, permitindo ao participante responder da forma que achasse mais adequada.

Na parte inicial, constava a caracterização do respondente, por sexo, idade, grau de instrução, formação e área de atuação. O participante também registrou a informação a respeito de qual ou quais dos periódicos é assinante. Quatro das perguntas constantes no questionário foram constituídas por respostas fechadas, devendo o respondente registrar seu grau de interesse por assuntos relacionados à ciência e ao meio ambiente e quais os níveis de participação real e ideal a respeito da conscientização existente sobre o tema mudanças climáticas. Nas demais questões, buscou-se aferir o quanto de conhecimento sobre o tema o respondente possui, com definições relacionadas a termos técnicos (por exemplo, efeito estufa) e medidas adotadas para combater o problema relacionado ao aquecimento global.

O APÊNDICE C traz o questionário destinado ao público.

\subsubsection{Perfil dos participantes}

Os participantes desta pesquisa na parte referente à percepção do público em geral a respeito do tema mudanças climáticas foram selecionados em uma amostra aleatória, seguindo os seguintes critérios: 
- Deveriam ser assinantes de pelo menos um dos seguintes periódicos: os jornais diários Folha de S. Paulo e O Estado de S. Paulo e as revistas semanais Veja e Época;

- não deveriam ser especialistas na área ambiental ou jornalistas;

- não deveriam trabalhar no setor nuclear, pelo fato de uma das questões buscar aferir o quanto o público em geral conhece a respeito da associação entre mudanças climáticas e energia nuclear.

Dos 108 participantes, 49 eram sexo masculino e 56 do sexo feminino, além de três que optaram por não se identificar. A maioria dos respondentes possui nível superior, sendo 68 superior completo (dentre esses, 3 com duas faculdades), outros 18 de nível superior com pós-graduação, três cursando pósgraduação; cinco frequentam curso superior atualmente. Dois participantes possuem superior incompleto, seis nível médio completo e dois cursam nível médio. Quatro participantes não registraram sua escolaridade. As FIG. 4.8 e 4.9 demonstram, respectivamente, o perfil dos participantes de acordo com o sexo e com a formação.

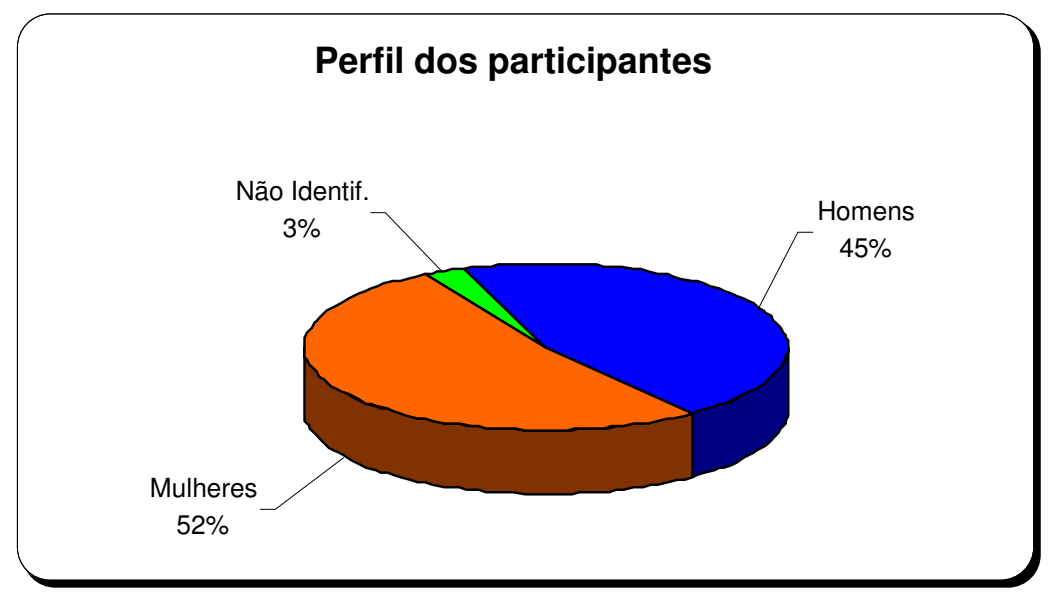

FIGURA 4.8 - Perfil dos participantes quanto ao sexo

Fonte - Elaborada pela autora 


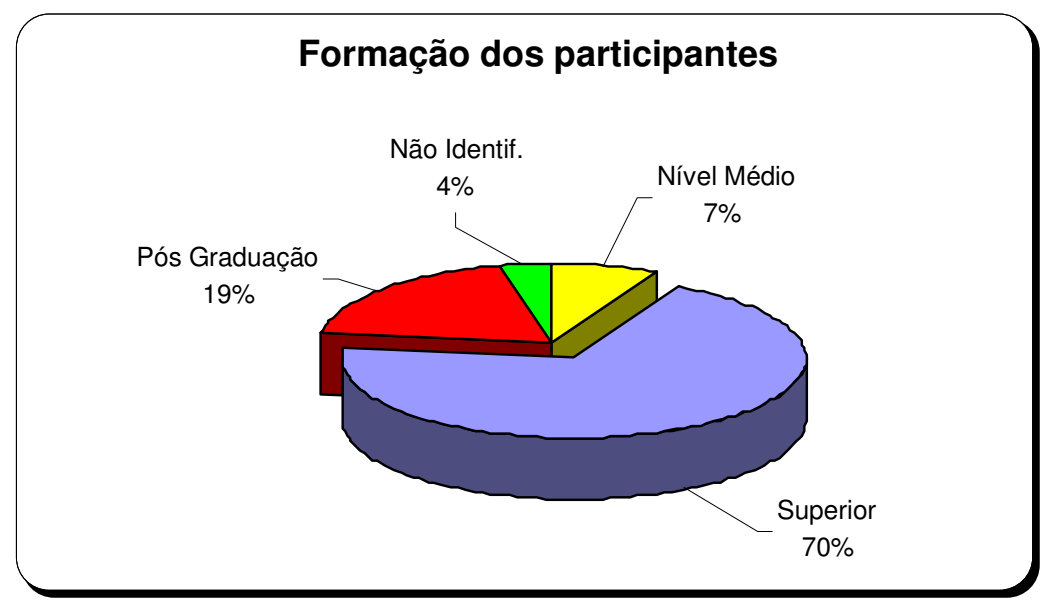

FIGURA 4.9- Perfil dos participantes quanto à formação

Fonte - Elaborada pela autora

Para os $70 \%$ com nível superior, as áreas de formação abrangem 26 carreiras. As ocupações compreendem vasta gama de atividades - de babá, taxista, bancária e cabeleireira a professores, economistas, administradores, engenheiros, advogados, médicos, empresários e tecnologistas, por exemplo.

No conjunto dos participantes predomina a faixa etária de 41 a 60 anos (50 respostas), seguida pela faixa de 20 a 40 anos (30 respostas). Outros 21 respondentes integram a faixa etária de mais de 61 anos e quatro estão na faixa etária de até 20 anos. Três participantes optaram por não identificar sua idade. $\mathrm{Na}$ FIG. 4.10 está retratada a distribuição dos respondentes por faixa etária.

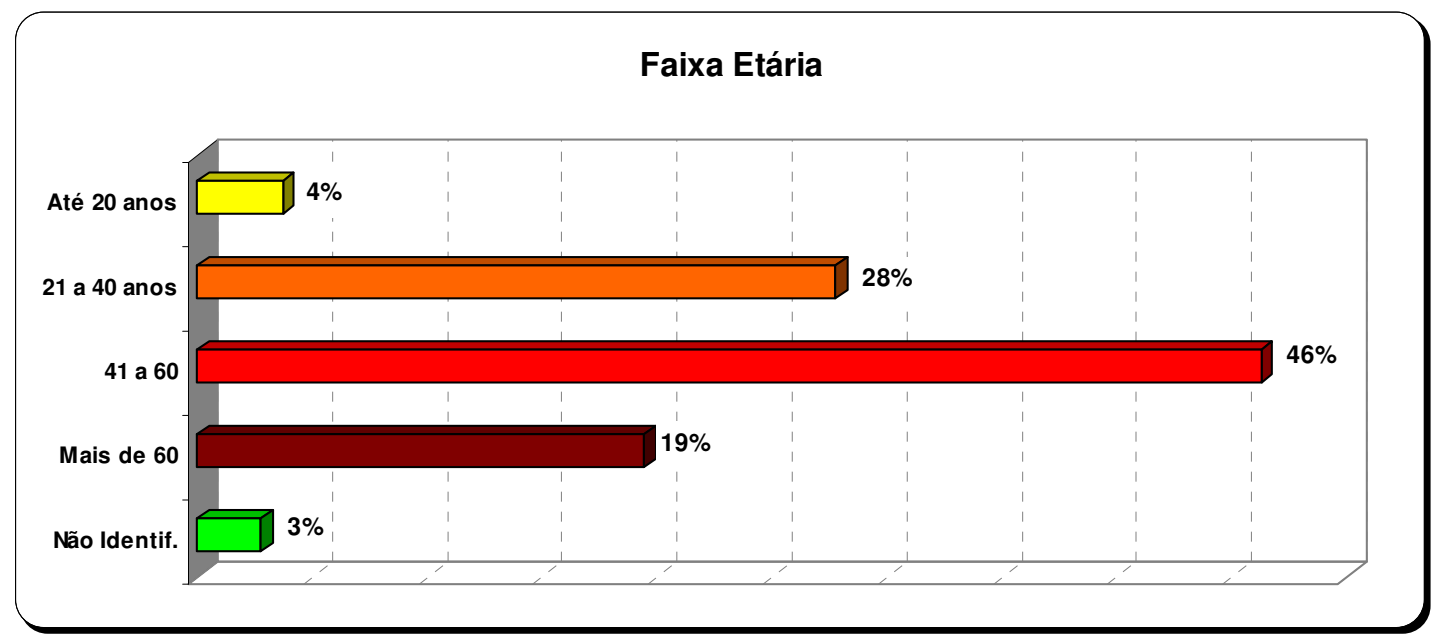

FIGURA4.10 - Perfil dos participantes quanto à faixa etária

Fonte - Elaborada pela autora 


\subsubsection{Acesso ao tema}

Contabilizam-se 53 assinantes de um periódico, outros 32 assinantes de dois periódicos e 23 de três ou mais, conforme esquematizado na FIG. 4.11. Todos assinam pelo menos um dos periódicos analisados neste trabalho. A partir do segundo título de jornal ou revista da qual o participante é assinante foram contabilizados outros jornais ou revistas de informação de âmbito nacional ou regional, por meio impresso ou eletrônico, de forma a tentar caracterizar de forma indireta o quanto o participante valoriza a busca por informação. Mais de $50 \%$ dos participantes assina pelo menos duas publicações. Alguns respondentes chegam a assinar seis publicações, entre as de jornalismo diário e semanal e revistas mensais de informação sobre ciência, carreira, negócios e destinadas a segmentos profissionais específicos. Fica evidenciada a destinação de receita regular para investimento em acesso a informação de forma significativa.

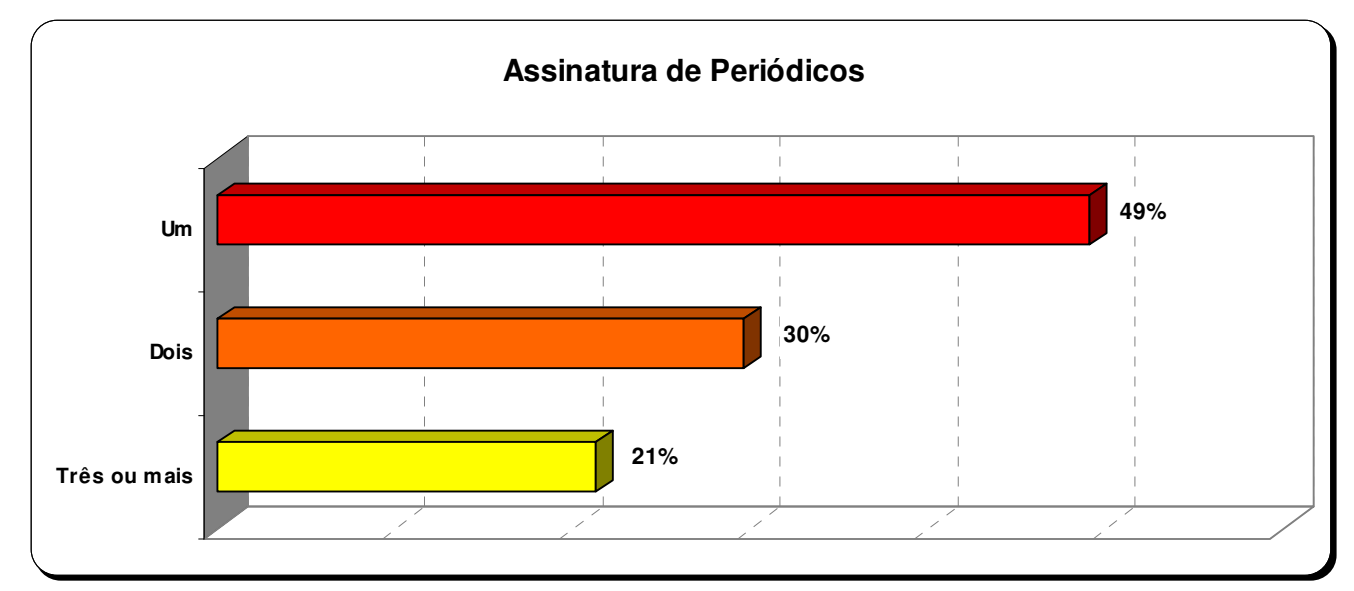

FIGURA 4.11 - Perfil dos participantes quanto à assinatura de periódicos

Fonte - Elaborada pela autora

Predomina o meio jornal impresso como fonte de acesso a informações sobre mudanças climáticas (61 citações), seguido por TV (53 citações), revistas e internet (49 citações para cada veículo). Apesar de a pergunta ter sido "Qual o principal meio de acesso a informações sobre o tema mudanças climáticas", a grande maioria dos participantes preferiu citar mais de uma mídia, por isso a somatória das citações é superior ao número de participantes da enquete. $\mathrm{Na}$ TAB. 4.6, o total de respostas. Outras respostas não especificadas na tabela são participação em movimentos, Greenpeace, WWF, relatórios, livros, seminários, conversa com filho (uma resposta para cada). 
TABELA 4.6 - Respostas do público sobre principal meio de acesso a informações sobre o tema mudanças climáticas

\begin{tabular}{lcc} 
& \multicolumn{1}{c}{ Meio } & Percentual de citações \\
\cline { 2 - 3 } Jornal & $26 \%$ \\
\cline { 2 - 3 } TV & $23 \%$ \\
\cline { 2 - 3 } Revistas & $21 \%$ \\
\cline { 2 - 3 } Internet & $21 \%$ \\
\cline { 2 - 3 } Leituras & $2 \%$ \\
\cline { 2 - 3 } Rádio & $2 \%$ \\
\hline Outros & $6 \%$ \\
\hline TOTAL & $100 \%$ \\
\hline
\end{tabular}

Fonte - Elaborada pela autora

\subsubsection{Interesse por temas científicos e ambientais}

No levantamento bibliográfico sobre a relação do público brasileiro com temas de ciências foi identificada uma pesquisa nacional de opinião promovida pelo Ministério da Ciência e Tecnologia com a parceria da Academia Brasileira de Ciências e conduzida pelo Departamento de Popularização e Difusão da Ciência e Tecnologia do MCT (Brasil, 2007). Nela foi investigado o interesse, grau de informação, atitudes, visões e conhecimento dos brasileiros a respeito de ciência e tecnologia. Responderam à pesquisa brasileiros a partir de 16 anos. Ao graduar o interesse por temas tais como medicina e saúde, política, esportes, entre outros, meio ambiente foi apontado como o segundo de muito interesse, perdendo apenas para saúde. O principal motivo indicado pelos que não se interessavam por temas de ciência e tecnologia, de modo geral, foi a falta de compreensão do assunto.

A partir dessa informação, foram inseridas duas perguntas no questionário destinado ao público:

- Qual seu interesse por ciência e temas relacionados à ciência?

- Qual seu interesse pelas questões ambientais?

O respondente deveria assinalar uma nota entre um e cinco, onde um significava nenhum interesse e cinco queria dizer muito interesse.

Para ciência, a nota média dos participantes do sexo masculino foi de 3,84 , enquanto o interesse pelo mesmo tema entre os respondentes do sexo feminino foi menor, de 3,59 . Houve três respostas de participantes que não se 
identificaram contabilizando média de 3,67. A média geral entre todos os pesquisados foi de 3,70. Nas FIG. 4.12 e 4.13 estão demonstrados os resultados obtidos.

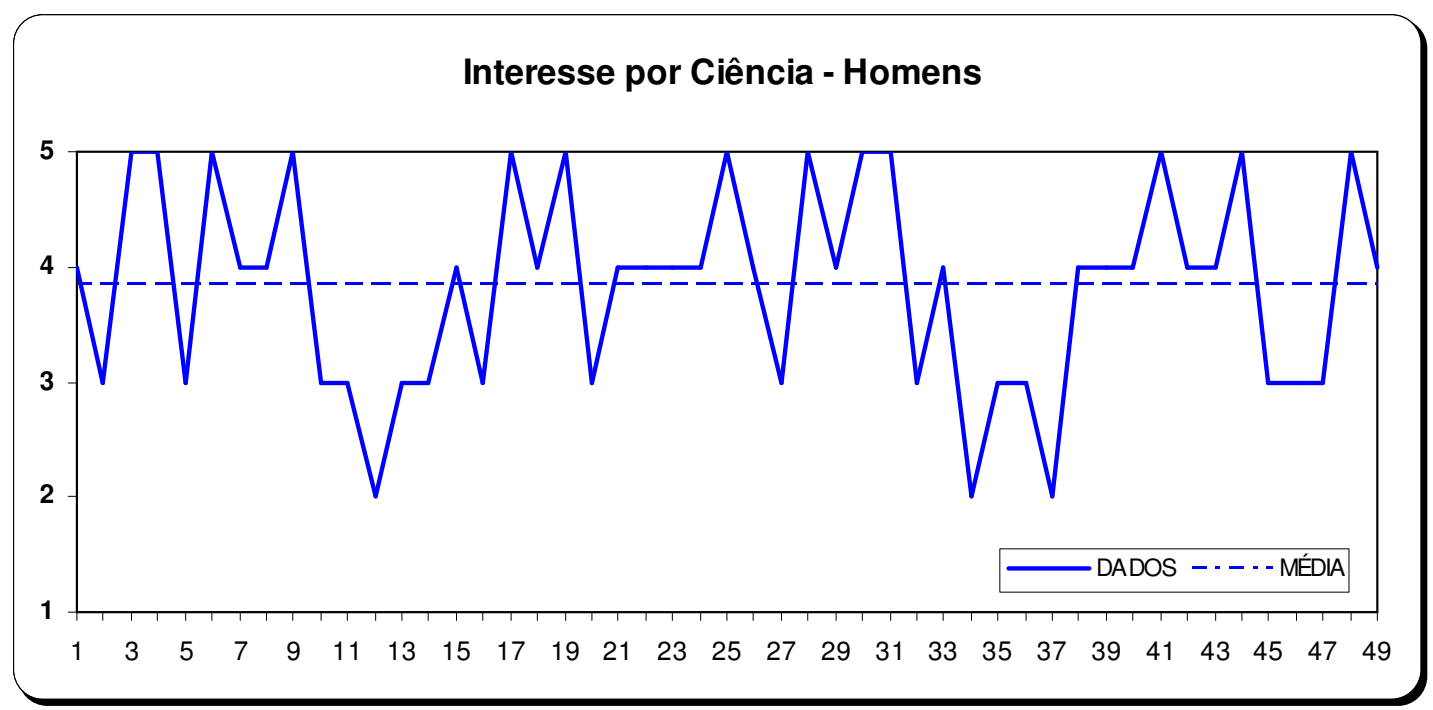

FIGURA 4.12 - Interesse por temas relacionados à ciência - Homens

Fonte - Elaborada pela autora

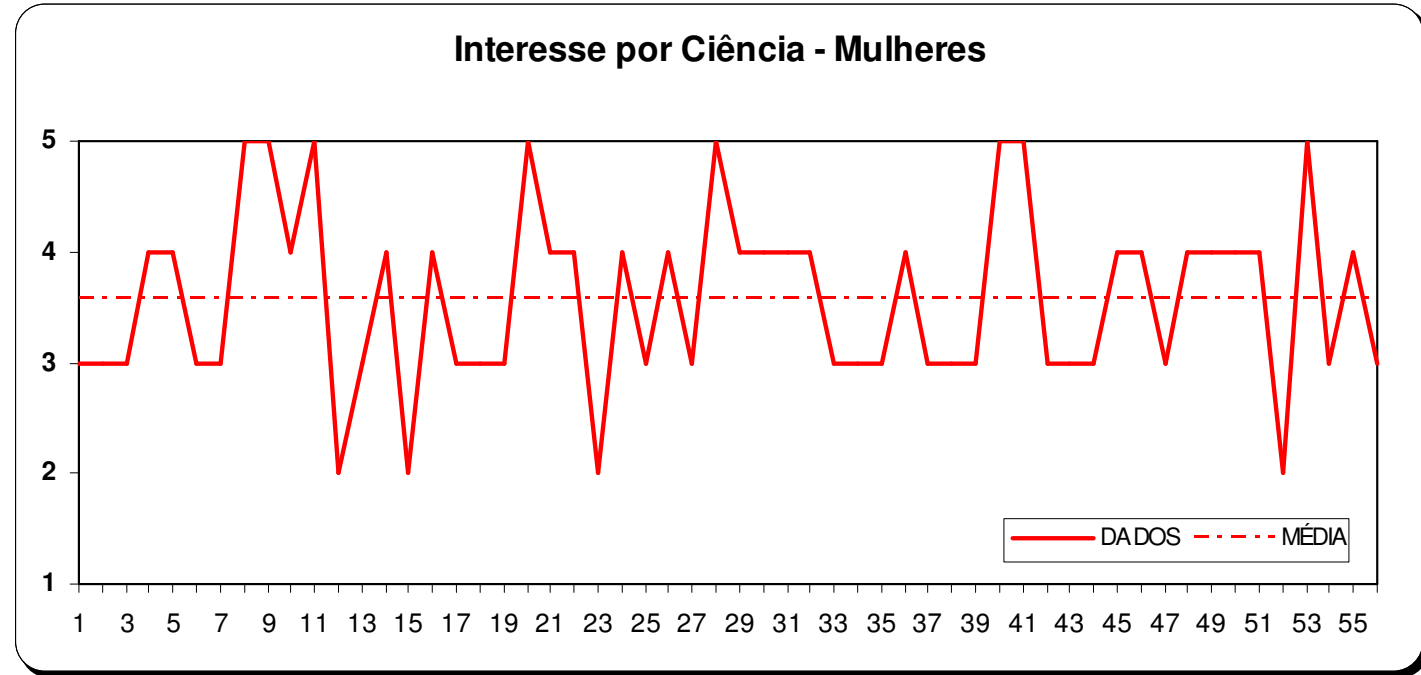

FIGURA 4.13 - Interesse por temas relacionados à ciência - Mulheres

Fonte - Elaborada pela autora

Já para as questões ambientais, a média de interesse foi de 4,02 para os homens e 4,18 para as mulheres. Entre os três participantes não identificados, a média foi 4,33. Como interesse médio total, o valor é de 4,18. Nas FIG. 4.14 e 4.15 estão demonstrados os resultados obtidos. 
Interesse por questões ambientais - Homens

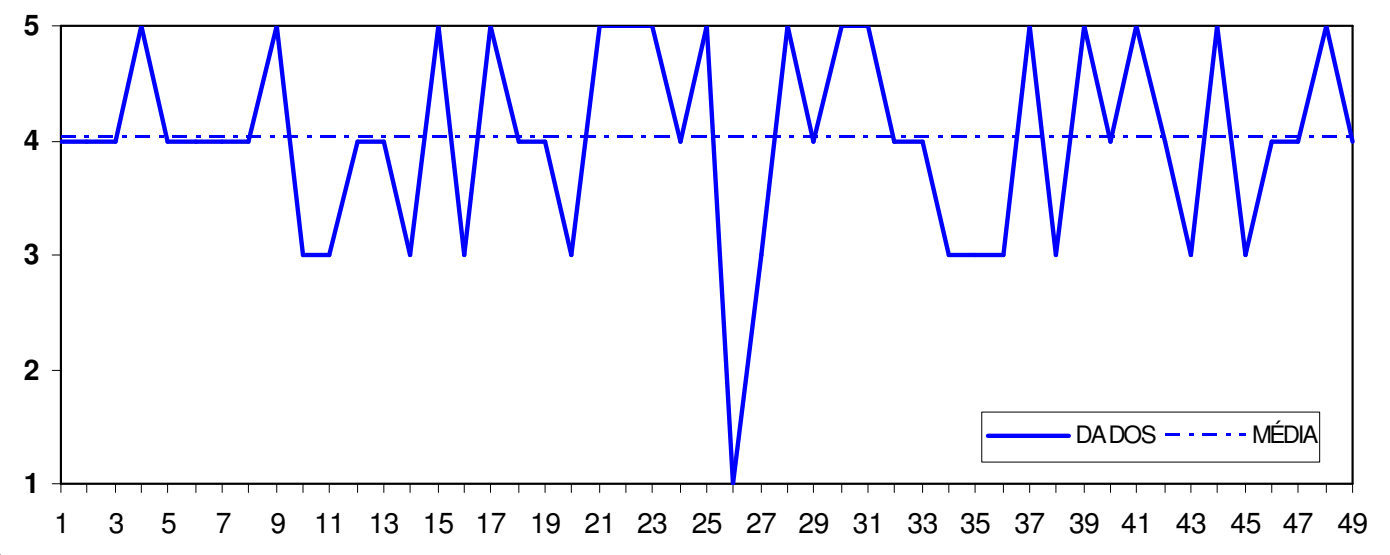

FIGURA 4.14- Interesse por temas relacionados ao meio ambiente - Homens

Fonte - Elaborada pela autora

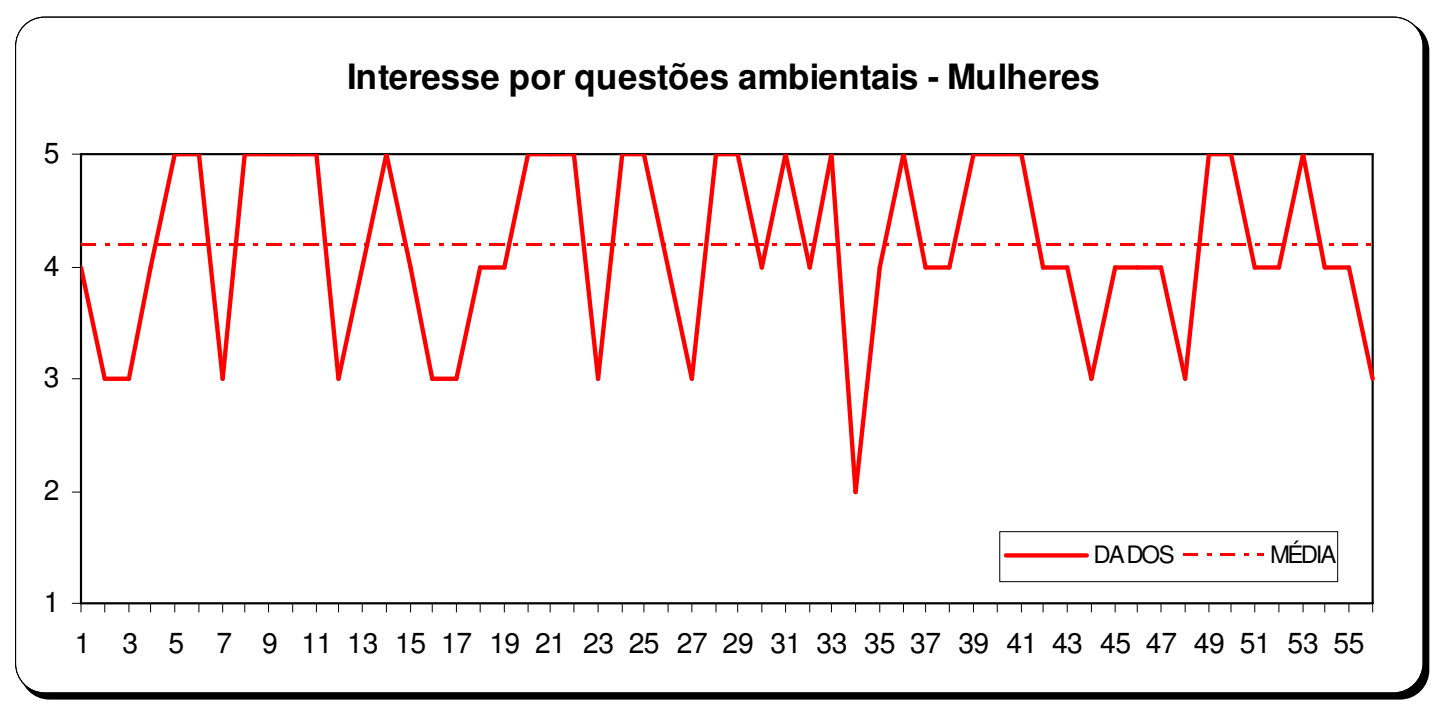

FIGURA 4.15- Interesse por temas relacionados ao meio ambiente - Mulheres

Fonte - Elaborada pela autora

Entre os entrevistados, percebe-se claramente que homens têm maior interesse em ciência do que mulheres. Para as questões ambientais, o interesse dos respondentes do sexo feminino supera o interesse dos respondentes do sexo masculino.

Comparando-se as médias gerais de interesse em ciência e meio ambiente, percebe-se que o interesse específico na temática ambiental é superior em aproximadamente $13 \%$. 


\subsubsection{Conceitos científicos e senso comum}

No questionário aplicado ao público, foram elaboradas duas perguntas com o objetivo de identificar como tem sido o grau de compreensão do público pesquisado a respeito do tema mudanças climáticas, de forma que algumas definições e conceitos científicos pudessem ser avaliados. As questões foram as seguintes:

- O que você sabe sobre mudanças climáticas?

- Como você define o efeito estufa?

Propositalmente, em nenhuma das questões foi utilizado o termo aquecimento global, para verificar como essa expressão seria relacionada a todas às demais utilizadas. De forma equivocada, mudanças climáticas, efeito estufa, aquecimento global costumam ser expressas como sinônimos. A explicação para a ocorrência do aquecimento global e a controvérsia a respeito do que estaria ocorrendo com o planeta no campo da variabilidade climática, conforme detalhado nos capítulos iniciais deste trabalho, também poderia aparecer ao longo do processo de respostas do instrumento de coleta de dados.

Ao mesmo tempo em que o acesso as mais diversas fontes de informação contribui para trazer atualidades sobre um determinado tema, pode concorrer para novas perspectivas, aprendizado, mudanças de conceitos e conscientização, neste caso em favor da temática ambiental.

Não se constituía em objetivo primordial da pesquisa trazer opiniões a respeito do tema, mas obviamente as respostas podem traduzir opiniões e emoções a respeito dos assuntos relacionados. Nessa expectativa, durante o processo de análise das respostas, as diferentes considerações registradas pelos respondentes foram anotadas. Na última parte do questionário, referente à possível associação entre energia nuclear e mudanças climáticas, foram registradas algumas opiniões manifestadas pelos participantes.

No que tange o conhecimento científico, percebe-se claramente respostas intuitivas, carência de conceitos científicos e algumas confusões no campo das definições, como nas respostas a seguir, que tentaram definir o que seria o efeito estufa:

- "Li sobre o efeito estufa. Por isso estão vindo as enxurradas, o vento forte". 
- "Uma inversão térmica que se apresenta fora das estações do ano".

- "Aquecimento gradual do clima, por conta dos buracos formados na camada de ozônio da Terra, que funciona como um escudo protetor natural do planeta. Esta camada vem sendo atacada por ações poluentes geradas pelo crescimento sem controle da população e por consequência das emissões de gases produzidos pelo homem".

O primeiro exemplo utiliza a definição de efeito estufa de forma equivocada. Em segundo lugar associa fenômenos que não apresentam necessariamente relação com as mudanças climáticas se tomados de forma isolada. No segundo exemplo, foi trazida uma informação de fenômeno que não se relaciona à questão mudanças climáticas. No terceiro exemplo foram mencionados os danos à camada de ozônio para conceituar efeito estufa, quando essa correlação não é correta.

$\mathrm{Na}$ questão "O que você sabe sobre mudanças climáticas", seis respostas - ou 5,5\% do total - mencionam que as mudanças climáticas são alterações resultantes da própria natureza. Uma delas parece cópia de definições constantes no IPCC. Uma resposta apenas deixa explícita a inquietação sobre o quanto se refere à ação humana ou à ação da própria natureza. Também houve confusões sobre o que se apresenta como mudança global do clima e degradação ambiental, que obviamente também contribui ou pode contribuir para impactos no clima. Vale à pena destacar as seguintes respostas:

- "São variações nas características regionais do clima ao longo do tempo; o clima não se repete ciclicamente como no passado".

- "Não saberia dizer quanto se deve à ação do homem quanto se deve à ação da natureza".

- "Antes de cuidar do meio ambiente, devemos cuidar do ser humano, investindo em educação e cidadania. Mudanças climáticas sempre existiram, mas desta vez por ação humana (...)".

- "Mudanças climáticas são provocadas por fenômenos naturais e principalmente pela ação do homem a partir da revolução industrial, que tem provocado o aumento da poluição através da emissão de gases e substâncias tóxicas na atmosfera. Acabam interferindo nos índices pluviométricos, temperaturas, umidade do ar entre outros".

- "Percepção no dia-a-dia - SP poluída, contaminação de águas". 
Há predomínio da associação do termo mudanças climáticas com aquecimento global. As respostas as relacionam ao fenômeno aquecimento global e consequências apontadas nos relatórios do IPCC. Também predomina a visão de que as mudanças se devem à ação do homem.

- "O mundo está aquecendo rapidamente".

- "A temperatura da Terra está aumentando. Número maior de catástrofes relacionadas com enchentes ou secas violentas".

- Aquecimento global; doenças novas; desflorestamento; desertificação na África; desaparecimento de espécies; poluição de solo, água, ar aumento incontrolado de cidades".

- "Resultantes da ação do homem; aumento da população".

- "Degradação ambiental e modificações feitas pelo homem estão alterando o clima".

Três respostas apontam para as diferentes visões a respeito das mudanças climáticas, quais sejam a postura adotada pelo IPCC e a do grupo chamado céticos. Em duas respostas, são mencionados os argumentos dos céticos sobre períodos experimentados pelo planeta de temperaturas mais quentes de forma alternada a outras mais amenas. Uma das respostas nessa linha de raciocínio é a seguinte:

- "Aparentemente há um aquecimento global a caminho. Há alguns estudos apontando para a influência do homem neste aquecimento, mas nenhum conclusivo. Vários desses estudos foram desacreditados nos últimos anos".

Na questão "Como você define o termo efeito estufa", a expressão gases de efeito estufa não foi utilizada, mas pode-se inferir que o participante se referia a esses elementos em algumas das respostas. Nas citações aos "gases", estes foram caracterizados como nocivos (3 citações), tóxicos (3 citações), elementos indesejáveis e poluentes (12 citações). Definições incompletas ou equivocadas predominam. Respostas corretas ou próximas da definição correta foram raras. Predominou ainda o uso do termo como sinônimo de aquecimento global ou poluição. Pelo fato de o conceito ser também intuitivo (palavra estufa utilizada na linguagem senso comum) há várias respostas que comunicam a essência do funcionamento de uma estufa, que na verdade ocorre com o fenômeno efeito estufa, de retenção do calor na superfície da Terra. A existência 
de poluentes na atmosfera foi apontada como causador do fenômeno, uma associação frequente entre os respondentes. Algumas das respostas constam a seguir:

- "Parte do calor recebido do sol pela terra fica retido por camada de gases nocivos presentes na atmosfera e este calor aumenta a temperatura na superfície da terra".

- "Garantia de vida".

- "Destruição da camada de ozônio causa tal efeito".

- "Emitimos muito $\mathrm{CO}_{2}$ e esse gás sobe e vai se acumulando, forma buracos na camada de ozônio. Ocorre o aumento de temperatura na Terra".

- "Furos na camada de ozônio".

- "Conseqüência da poluição, mau uso de elementos até então desconhecidos".

- "Acúmulo de poluentes na atmosfera, que retém o calor na Terra produzido pelos raios solares, aumentando por consequência o aquecimento global".

- "Efeito provocado pela emissão excessiva de $\mathrm{CO}_{2}$, que impede a dissipação natural do calor recebido do sol”.

- "Superaquecimento causado por gases, poluição, que destroem a camada de ozônio, que protege os seres vivos dos raios ultravioleta".

- "Radiação solar, presa em uma parte da atmosfera devido à poluição, e essa radiação não é liberada, ficando presa e provocando o efeito estufa".

- "Também chamado efeito invernadeiro. É um dos principais fatores para o aquecimento global. $O$ nome vem da semelhança com os galpões utilizados em cultivos para manter o calor no interior da instalação".

O efeito estufa também foi citado como altamente maléfico à humanidade. Houve 12 citações ao gás carbônico na pergunta sobre o que é o efeito estufa, 2 citações ao metano e 1 citação aos CFCs.

\subsubsection{Sobre o combate à mudança do clima}

Aos participantes, foi pedido que citassem duas palavras das quais lembrassem imediatamente quando pensavam no tema mudanças climáticas. Alguns respondentes citaram mais de duas palavras. O resultado pode ser visualizado na TAB. 4.7. Expressões que apareceram nas respostas uma vez 
foram: mudanças dos polos, mortes, hipocrisia, política, irresponsabilidade, descaso, descompensação, descontrole, instabilidade, vidas, qualidade de vida, sol, futuro, pegada ecológica, natureza, verde, preservação, créditos de carbono, consumo, temporal, tempo, fenômenos climáticos, doenças respiratórias, ações urgentes, inversão térmica, meteorologia, carros, ventos (fortes), terremotos, Michael Moore. Outro preferiu registrar: o sertão vai virar mar/ o mar vai virar sertão. Outro registrou apenas uma resposta: "tá ficando quente". Dentre todos os respondentes, quatro participantes citaram apenas uma palavra ou expressão, ao invés de duas. Dois participantes registraram que não sabiam responder.

TABELA 4.7 - Palavras associadas ao tema mudanças climáticas.

\begin{tabular}{lr}
\hline Termo & $\begin{array}{r}\text { No de } \\
\text { respostas }\end{array}$ \\
\hline Aquecimento & 29 \\
\hline Degelo ou Derretimento ou Geleiras & 19 \\
\hline Poluição & 15 \\
\hline Temperatura & 13 \\
\hline Calor & 10 \\
\hline Desmatamento & 9 \\
\hline Estufa & 9 \\
\hline Água & 7 \\
\hline Enchentes ou Inundações & 7 \\
\hline Camada de ozônio & 5 \\
\hline Catástrofes & 5 \\
\hline Destruição & 5 \\
\hline Seca & 4 \\
\hline Frio & 3 \\
\hline Chuvas & 3 \\
\hline Desastres & 3 \\
\hline Gás carbônico & 3 \\
\hline Homem & 3 \\
\hline Desequilíbrio & 2 \\
\hline El Niño & 2 \\
\hline Furacões & 2 \\
\hline Sustentabilidade & 2 \\
\hline Emissões & 2 \\
\hline Fogo (na floresta) & 2 \\
\hline Extinção (de espécies) & 2 \\
\hline Amazônia & 2 \\
\hline Ambiente & 2 \\
\hline Protocolo de Kyoto & 172 \\
\hline Total & \\
\hline pela auto & \\
\hline
\end{tabular}

Fonte - Elaborada pela autora 
Interessante notar que diante de toda a discussão com relação à sustentabilidade, mudanças de hábitos e atitudes ante a degradação ambiental experimentada pela humanidade, apenas um participante associou mudanças climáticas a consumo. Claro que este é um exercício mental que busca respostas imediatas a uma questão apresentada e envolve aspectos subjetivos na escolha do termo a ser registrado, mas é no mínimo curioso que apenas um respondente tenha se lembrado da palavra consumo. Esta observação é capaz de despertar reflexões e pode sinalizar como o homem reage ou pensa diante dos desafios ambientais. Outra questão interessante é que houve apenas dois registros ligando mudanças climáticas à extinção de espécies, embora o país seja detentor de $20 \%$ da biodiversidade mundial. Política foi uma palavra lembrada por apenas um dos participantes, embora essa componente tenha uma participação de peso no noticiário impresso do período analisado. Entretanto, o enfoque predominante das reportagens publicadas no período foram as políticas dos países desenvolvidos e não medidas nacionais.

Vale lembrar que a busca por informações e o interesse por determinada questão é o primeiro passo na longa caminhada por mudança de atitudes. Na avaliação geral, pode-se identificar que a maioria das citações está relacionada às palavras recorrentes na imprensa ao tratar do assunto.

Para a pergunta "Conhece algo que o Brasil está fazendo no combate às mudanças climáticas", 27 respondentes - 25\% do total - afirmaram desconhecer ações em curso. Como havia a possibilidade de quantos exemplos o respondente achasse adequado, alguns entrevistados registraram mais de uma resposta. Foram 23 citações ao combate, redução ou controle do desmatamento, ou $21 \%$ do total. A referência a energias renováveis ou combustíveis alternativos apareceu em 13 respostas (12\%). Metas de redução de gases e discussões com essa finalidade foram mencionadas em 8 respostas (7\%). Igual número de citações para o controle de emissões veiculares, que ocorre desde 2008, em São Paulo (Controlar, 2008). Reciclagem foi mencionada em 6 respostas (5,5\%) e Protocolo de Quioto, em 4 respostas (3,7\%). Na FIG. 4.16, uma síntese das respostas obtidas. 


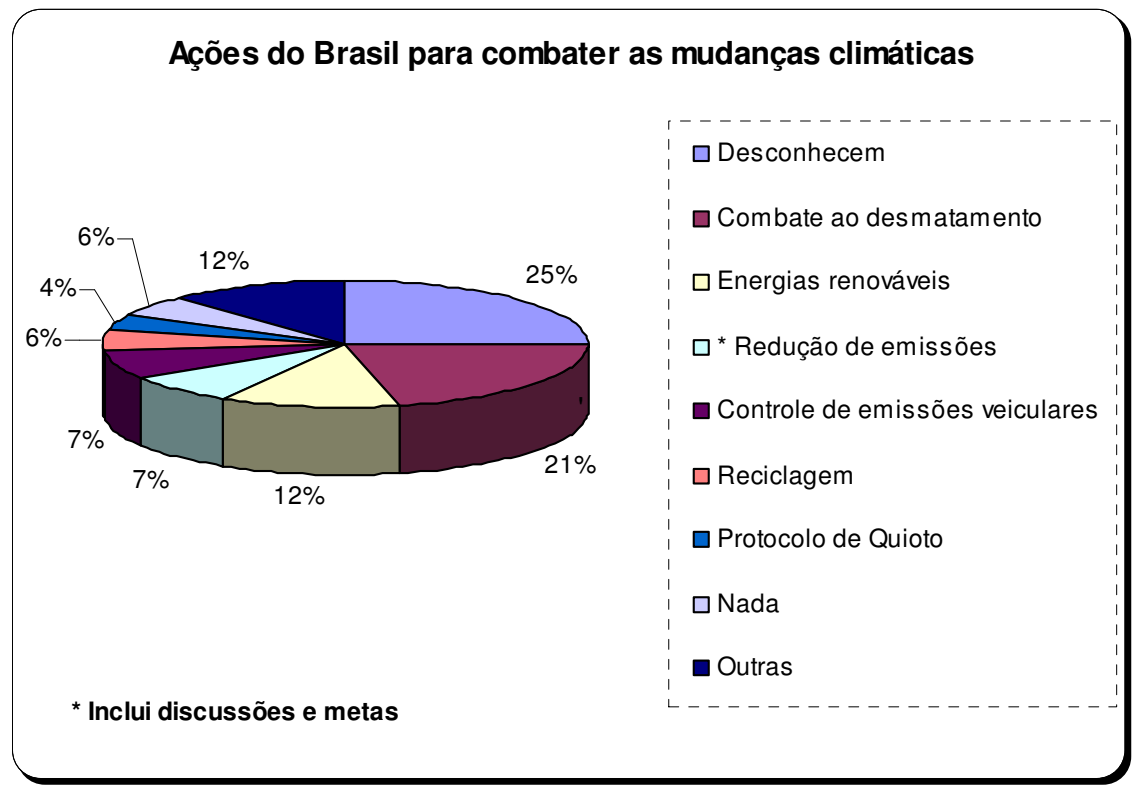

FIGURA 4.16 - Ações de combate às mudanças climáticas - Brasil

Fonte - Elaborada pela autora

É importante salientar que o programa de inspeção e manutenção de veículos não atinge todo o país. Apenas os Estados de São Paulo e Rio de Janeiro realizam a inspeção. A partir da Resolução do Conselho Nacional do Meio Ambiente (Conama) № 418, de 25 de novembro de 2009, publicada no Diário Oficial da União de 26 de novembro de 2009, tornou-se obrigatória a inspeção veicular nos Estados e cidades do país com mais de 3 milhões de veículos (AMBIENTE BRASIL, 2009). O programa pode ter impactos na questão de controle de emissões de GEE, mas o Brasil não tem metas com relação à diminuição de emissões veiculares. Ou seja, trata-se de uma medida em estágio inicial e ainda com poucos impactos.

Portanto, o combate ao desmatamento e o uso de renováveis ou combustíveis alternativos (referências ao etanol e uso de biocombustíveis) são as ações mais lembradas pelos participantes. Houve seis registros sobre a falta de ações do país para combater as mudanças climáticas, conforme os exemplos seguintes de respostas:

- "Nada! Destruímos a Amazônia por interesses políticos e econômicos".

- "Acredito que não esteja fazendo nada". 
- "Tentativa de acabar com o desmatamento. Algumas ONGs, não muito confiáveis. Enfim, praticamente nada. Reciclagem é feita como meio de sobrevivência. Não em termos de preservação".

- "O Brasil tem muita promessa, muita conversa, mas desconheço ações governamentais sérias para esse assunto".

Dentre a seis citações à reciclagem, uma continha crítica porque seria realizada como meio de sobrevivência para as pessoas, mas não pela necessidade de preservação ambiental. Um dos respondentes registrou que falta informação para a população e que seria necessário incentivo à conscientização. Nesse sentido, quatro respondentes apontaram a necessidade de conscientização sobre o tema ou a educação ambiental sendo mais discutida como ação do país no campo de combate às mudanças climáticas. Quatro participantes do sexo feminino se referiram à existência de conscientização. Uma delas aponta que as campanhas de conscientização ocorrem nas escolas de ensino fundamental e médio. Para os do sexo masculino que citaram esse aspecto (apenas dois), este é um caminho que ainda não foi trilhado. Um deles afirmou que ONGs têm dado sua parcela de contribuição ao promover a conscientização, embora se tratem de ações pontuais. Outro lembra que falta ainda muito a ser feito. Parte da resposta é transcrita:

- “(...) Muito mais pode e deve ser feito. Basta estabelecer metas reais e concretas e estabelecer leis que façam com que empresas também participem e façam sua parte reduzindo as emissões de gases, poluindo menos nossos rios e tomando seu papel de parte de sociedade investindo em projetos que promovam da conscientização e mudanças de atitudes".

Cinco participantes afirmaram que falta empenho das autoridades para a questão da preservação dos recursos naturais. Uma resposta lembra o grupo Greenpeace, que "luta para que não ocorram mais desvios climáticos".

Outras respostas pontuais foram: Projeto Tamar, SOS Mata Atlântica (duas respostas), combate a queimadas (duas respostas), leis que não são cumpridas, aprovação do Código Florestal, fiscalização de criadores suínos e bovinos para uso de biodigestores. As respostas refletem em muitos casos a área de experiência dos participantes, como por exemplo Direito ou agronegócio. 
Depois de responder sobre as ações no país de combate às mudanças climáticas, o participante deveria relacionar as ações mundiais nesse campo. Foi feita a seguinte pergunta:

"Conhece algo que está sendo realizado em âmbito mundial no combate às mudanças climáticas?"

Um percentual menor de participantes afirmou não saber citar ou desconhecer a resposta. Foram 18 afirmações dessa natureza, ou 16\% dos entrevistados. Houve 20 citações a Quioto, 18 citações a conferências, reuniões, discussões e tentativas de acordos, 10 citações a esforços de controle ou redução de gases poluentes e outras sete a redução de emissões de carbono. No que se refere ao "controle de gases poluentes", algumas respostas contêm crítica aos "resultados pífios" obtidos. Créditos de carbono tem três citações, renovação da frota uma citação e reciclagem duas citações. Para investimento em fontes de energia renováveis, diversificação da matriz energética e substituição de combustíveis fósseis houve 10 respostas nesse sentido. O IPCC teve uma citação nas respostas, menos do que o Greenpeace, lembrado em quatro respostas "por suas ações de combate às mudanças climáticas", e o ex-vice-presidente dos Estados Unidos Al Gore, mencionado em 3 respostas.

Em dez respostas houve críticas em relação às medidas que têm sido adotadas em menor escala do que o necessário e possível. Na FIG. 4.17, um resumo esquemático das respostas obtidas para a questão.

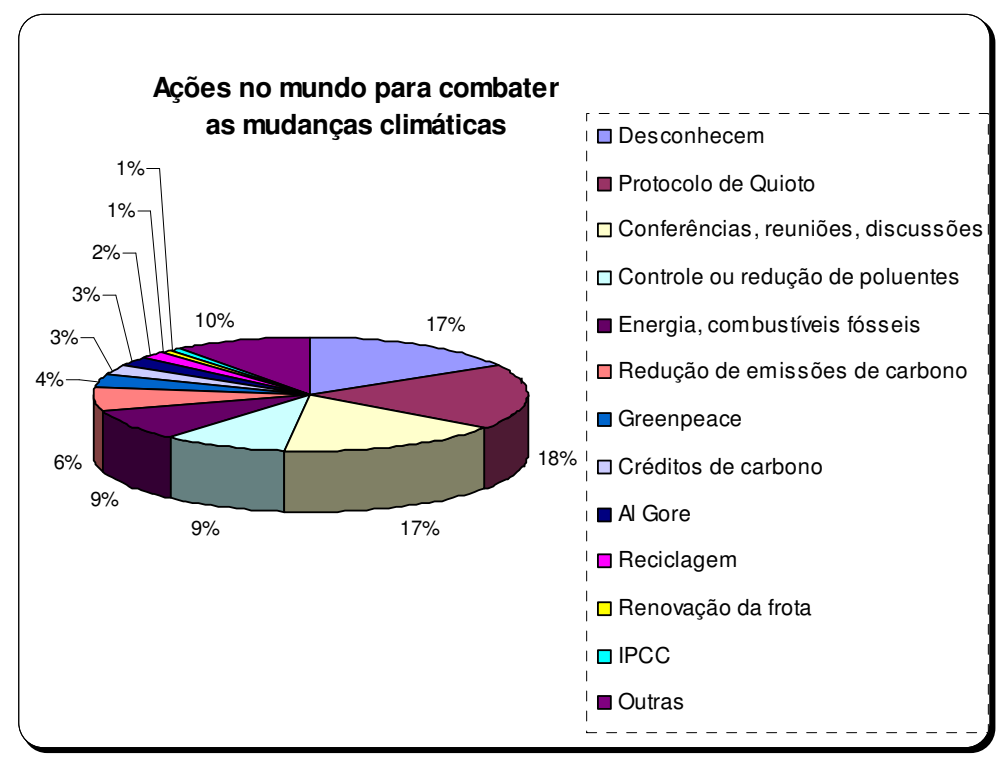

FIGURA 4.17 - Ações de combate às mudanças climáticas - Mundo Fonte - Elaborada pela autora 
Algumas das respostas estão registradas a seguir:

- "Protocolo de Kyoto, COP 15, Eco 92 (todas com pouco sucesso)".

- "Discussões em âmbito mundial para estabelecimento de controle de emissão de gases prejudiciais à atmosfera".

- "Alguns tratados são assinados, mas as potências não abrem mão de seus interesses".

- "No início de 2010 houve um congresso mundial para estabelecer políticas globais no combate a estas mudanças".

- "Reuniões de alto nível visando estabelecer ações e metas para horizontes futuros, relativas ao controle e redução da poluição em escala mundial".

- "Planos que visam o reequilíbrio do sistema dentro do programa de sustentabilidade, lixo nuclear etc".

- "Troca dos combustíveis de fontes não renováveis por combustíveis de fontes renováveis. Ex. motor a gasolina por motor elétrico".

- "Projetos de proteção de águas, florestas".

- "Documentário de Al Gore conseguiu que a mídia e as pessoas olhassem para o problema (conscientização). São pequenos hábitos que vão mudando o mundo".

- "Diversos países assinaram acordos para diminuir as emissões de $\mathrm{CO}_{2}$. A sustentabilidade está mais em pauta. $\mathrm{Na}$ bolsa de valores listadas as empresas sustentáveis".

- "Nada que produza efeitos significativos. A última conferência na Europa foi um fiasco".

- "Leio sobre palestras do Al Gore, protocolos. O que foi feito efetivamente eu não sei. Mas a mídia é muito importante para explicar. Acho importante que hoje nas escolas as crianças estão sendo conscientizadas, coisa que a geração passada não tinha".

- "Vários movimentos de conscientização, as reuniões do COP-15,16... que deverão definir os acordos sobre mudanças climáticas, porém estes acordos estão difíceis de acontecer e na prática nada de concreto acontece".

- "Debates no IPCC. Deste, existe a tentativa de se criar protocolos entre os países para redução significativa de emissões gasosas com impacto no efeito estufa".

- "Corrida por carros híbridos ou elétricos. Procura por energias renováveis". 
- "Tentativa de acordo entre os países, porém não está funcionando. O que mais existe hoje são atitudes individuais ou de pequenos grupos para tentar mitigar os efeitos das mudanças climáticas".

\subsubsection{Energia nuclear em pauta}

A questão que procurou verificar o nível de informação sobre a relação entre energia nuclear e mudanças climáticas apresentou resultado bastante diferenciado em relação às demais, por conta do elevado grau de desconhecimento sobre o assunto. A pergunta apresentada foi:

"Você percebe alguma associação entre energia nuclear e mudanças climáticas? Qual (is)?"

Dos 108 respondentes, 47 não percebem relação entre energia nuclear e mudanças climáticas, três dizem perceber associação entre os termos mas não responderam qual e dois não responderam. Somados, contabilizam quase metade dos participantes (48\%), um número bastante significativo.

O questionário não teve como objetivo principal aferir opinião do participante, mas seu nível de informação e conhecimento a respeito do tema. Entretanto, alguns manifestaram suas opiniões, mostrando fatos, opiniões e emoções ao tratar da temática nuclear, que geralmente é cercada de polêmica, dúvidas e preconceitos.

As respostas, para melhor análise, podem ser divididas em quatro grupos:

- Grupo 1 - Grupo do desconhecimento: formado por 52 participantes;

- Grupo 2 - Considera que nuclear não envolve queima de combustíveis fósseis: formado por 29 participantes;

- Grupo 3 - Nuclear é prejudicial (ou contribui para as mudanças climáticas): formado por 15 participantes;

- Grupo 4 - Não respondeu de forma direta à questão; comentou aspectos relacionados (positivos ou negativos) ou cometeu erros de informação: formado por 12 participantes.

Um resumo esquemático é apresentado na FIG. 4.18. 


\section{Associação entre energia nuclear e mudanças climáticas}

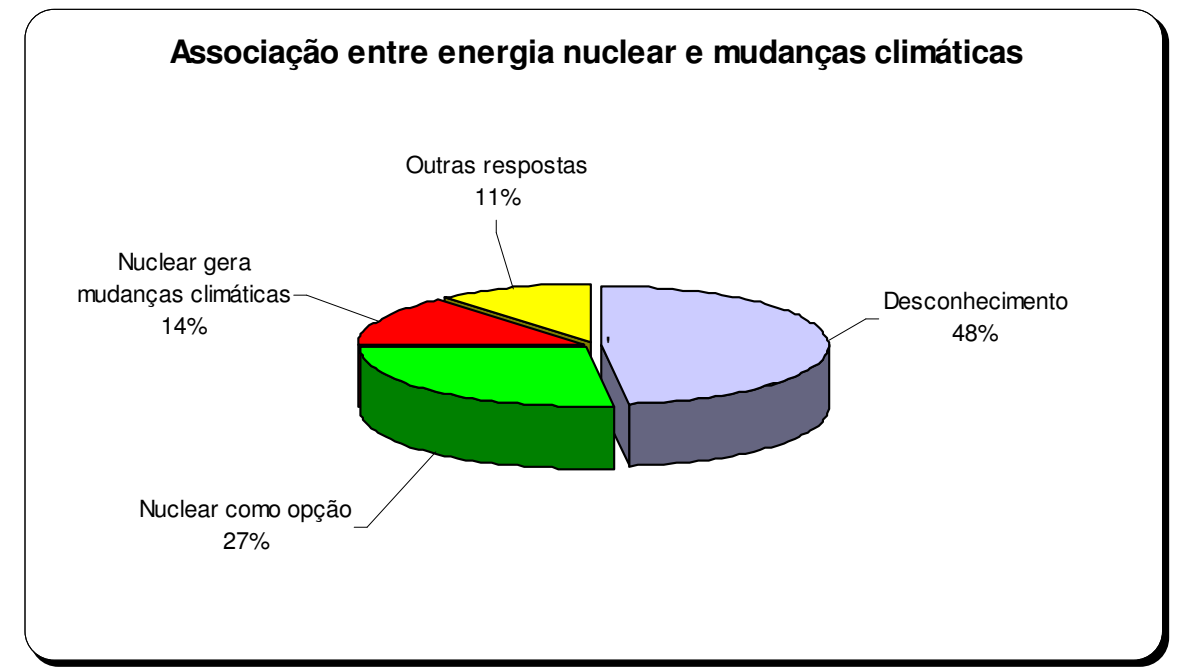

FIGURA 4.18 - Associação entre energia nuclear e mudanças climáticas Fonte - Elaborada pela autora.

No grupo 1, entre os que não associaram energia nuclear e mudanças climáticas, houve quem registrasse seu temor em relação à opção nuclear, mesmo lembrando a aplicação da tecnologia na área médica:

- "Não conheço. A principal aplicação seria nas pesquisas e novas tecnologias médicas. Energia nuclear ainda é algo assustador no quesito segurança".

$\mathrm{Na}$ FIG. 4.19, um detalhamento das respostas apresentadas pelos respondentes que afirmaram desconhecer a associação entre energia nuclear e mudanças climáticas.

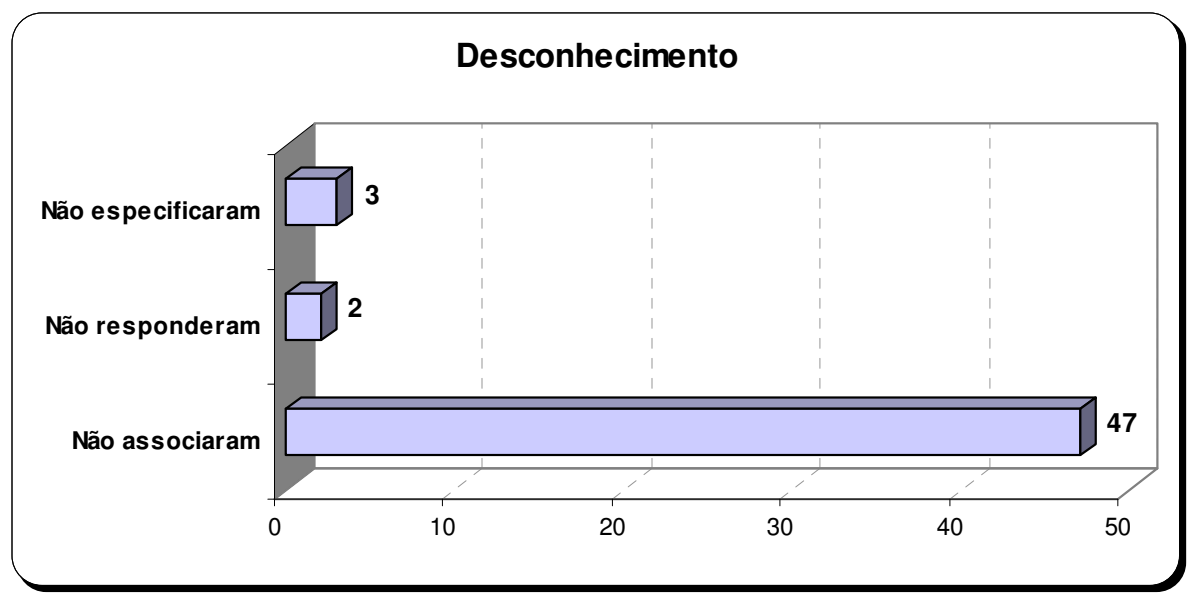

FIGURA 4.19 - Participantes que desconhecem associação entre energia nuclear e mudanças climáticas (Grupo 1)

Fonte - Elaborada pela autora 
No grupo 2, entre os 29 respondentes, 18 consideraram a energia nuclear alternativa para combater as mudanças climáticas, nove consideraram nuclear opção porém destacaram aspectos desfavoráveis ou riscos intrínsecos como por exemplo a deposição de resíduos radioativos, o acidente de Chernobyl ou risco de contaminação -, enquanto dois afirmam que nuclear tem baixa emissão de $\mathrm{CO}_{2}$ mas não sabem se é a melhor alternativa. Ou seja, 27 respondentes (25\%) apontam nuclear como alternativa. Seja porque possui mais vantagens que desvantagens, porque se constitui em "energia limpa" ou pelo fato de já terem lido que seria uma forma de combater o aquecimento global mas não sabem o porquê. Os dois participantes que afirmaram que nuclear apresenta baixa emissão de $\mathrm{CO}_{2}$ mas não sabiam se seria a melhor alternativa destacam como aspectos desfavoráveis a questão de segurança e o custo financeiro. Algumas das respostas considerando a energia nuclear como alternativa:

- "Já li que energia nuclear seria uma forma de combater o aquecimento global, mas também não sei de momento citar o porquê".

- "Energia nuclear é uma energia limpa, não polui, não gerando mudanças climáticas".

- "Acredito que a energia nuclear seria uma ótima alternativa neste momento".

- "Sei que a energia nuclear possui mais vantagens do que desvantagens com relação às mudanças climáticas. Influência menor ao clima".

- "Energia nuclear é uma energia limpa, não polui, não gerando mudanças climáticas".

- "Exploração da energia nuclear de forma responsável, em substituição a outras formas de energia, pode contribuir muito para minimizar os efeitos do aquecimento global".

- "A energia nuclear, pelo que eu saiba, não gera CO. Sobre esta ótica é melhor que a térmica a carvão, óleo, gás quanto à mudança climática".

- "Diz-se que a energia elétrica de origem nuclear influi (de uma forma geral) bem menos que os outros tipos de geração de energia no meio ambiente".

Neste grupo, entre os que consideraram nuclear como opção porém destacaram aspectos desfavoráveis, estão as respostas a seguir:

- "A energia nuclear é considerada uma energia limpa, já que não gera emissão de gases poluentes. Mas há outros pontos desfavoráveis, como os resíduos radiológicos". 
- "Se utilizada para fins pacíficos a energia nuclear pode ser uma das soluções para a diminuição da poluição, provocada por outras formas de energia, principalmente as fósseis, que tem papel fundamental na desestabilização climática do planeta. Os países desenvolvidos já se utilizam da energia nuclear em substituição ao petróleo, mas alguns riscos não devem ser preteridos, como sua utilização para fins militares e eventuais riscos de contaminação".

- "Forma de se produzir energia sem uso da queima de combustíveis fósseis ou carvão vegetal. Porém seu uso é acompanhado de um enorme risco para as populações próximas às usinas, além do problema gerado pela destinação dos resíduos dos materiais radioativos".

- "Energia nuclear é considerada fonte que não provoca aquecimento global. No entanto, a energia nuclear apresenta outros aspectos problemáticos, como as radiações, que já provocaram desastres ambientais (Chernobyl é um dos exemplos). No Brasil, um fenômeno conhecido é o que ocorreu em Goiás, há algumas décadas (componentes radioativos de equipamentos que não foram descartados corretamente e provocaram doenças graves nas pessoas que foram expostas a eles)".

- "Parece-me que a energia nuclear, por não emitir fumaça poluente (como as termoelétricas), parece mais adequada ao controle de emissão de poluentes, trazendo, contudo, o lixo radioativo como consequência".

- "Forma pouco poluente. O problema é a deposição de resíduos nucleares".

Dois respondentes comentaram sobre o potencial da energia nuclear e o papel que ela poderia desempenhar, porém manifestaram dúvidas sobre a adoção desta componente na matriz energética. As respostas foram contabilizadas no grupo 3. Como a pergunta não explorava esse nível de detalhamento, registra-se aqui as manifestações:

- "A energia nuclear é considerada uma alternativa a não emissão de $\mathrm{CO}_{2}$, porém oferece também outros impactos negativos no meio ambiente".

- "Há os que defendem que a energia nuclear é menos poluente. No entanto, há que se considerar a relação custo benefício não somente em termos de emissão de gases, mas também aspectos de segurança e custo financeiro".

Um resumo das principais ponderações do grupo 2 é apresentado na FIG. 4.20. 


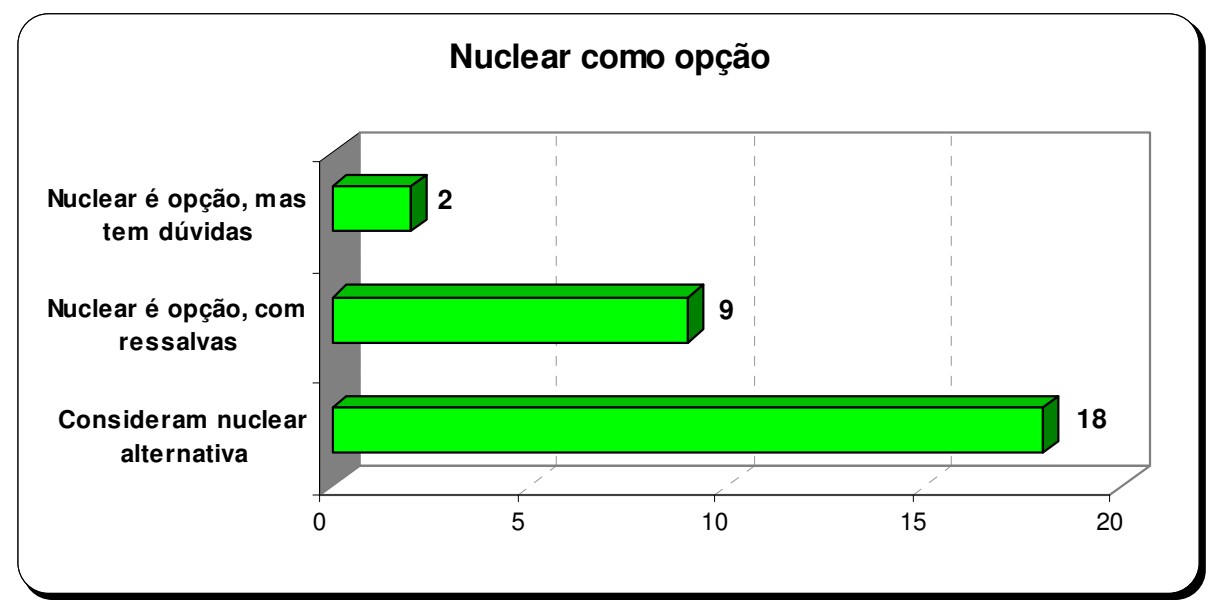

FIGURA 4.20 - Participantes que consideram a energia nuclear como alternativa (Grupo 2) Fonte - Elaborada pela autora

No grupo 3, a maioria das respostas está equivocada, por apresentar incorreções do ponto de vista técnico. Entre os 15 participantes há menções a processos de funcionamento de uma usina nuclear que contribuiriam para mudanças climáticas deletérias. Duas respostas apontam o "lixo" da usina como algo capaz de ocasionar mudanças climáticas.

- "A transformação da energia nuclear implica em mudanças climáticas, assim como toda a interferência humana".

- "Há outras formas de energia preferíveis. Acho que futuramente a energia nuclear pode afetar o clima negativamente".

- "Energia nuclear afeta sensivelmente para mudanças climáticas. Aumento de poluição e prejuízo para a natureza".

- "O uso indiscriminado, irresponsável e com fins bélicos da energia nuclear pode provocar graves mudanças climáticas".

- "Percebo algumas (associações): aquecimento; poluição das águas e do ar".

- "Testes nucleares são prejudiciais ao meio ambiente. Lembro de ter lido que poderiam causar mudanças climáticas".

- "Aquecimento das águas usadas no processo de esfriamento dos reatores. Energia nuclear como opção às termoelétricas e hidroelétricas. Risco de vazamento nuclear e prejuízo ao meio ambiente".

- "Usinas nucleares utilizadas para geração de energia elétrica estão sujeitas a acidentes que podem prejudicar o meio ambiente". 
- "O lixo de uma usina ou mesmo sua construção mudam o meio ambiente, trazendo alterações climáticas".

Na FIG. 4.21 estão representadas as respostas do denominado grupo 3, que considerou ser a energia nuclear prejudicial (ou contribuir para as mudanças climáticas).

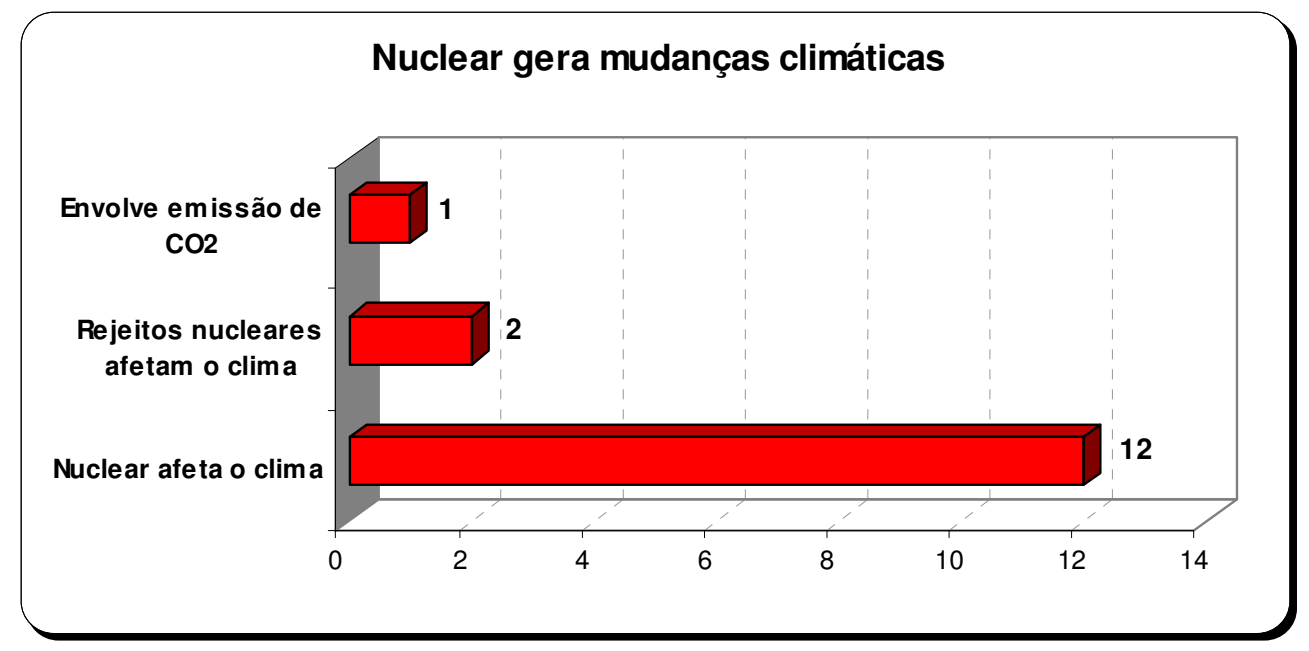

FIGURA 4.21 - Participantes que consideram que energia nuclear gera mudanças climáticas (Grupo 3)

Fonte - Elaborada pela autora

No grupo 4, formado por 12 integrantes, encontram-se incorreções do ponto de vista técnico e manifestações sobre temores de que a energia nuclear cause acidentes ou seja utilizada para fins perigosos. Embora seja possível compreender as opiniões e posicionamento dos respondentes frente à opção nuclear, grande parte das respostas não apresenta correlação direta com a pergunta. Duas respostas, apesar de também não satisfazerem o questionamento proposto, demonstram que o respondente seria favorável à energia nuclear. Destacam-se a seguir algumas delas:

- "Existe sim associação e o mais grave é que o Brasil está do lado de quem produz e até pode utilizar para meios violentos".

- "A energia nuclear solta resíduos nucleares na atmosfera".

- "Resíduos que o homem ainda não sabe o que fazer e vai ter que jogar na natureza, aumentando os danos a natureza".

- "As usinas nucleares emitem calor, tanto na água que serve para seus reatores como no ar". 
- "Risco de vazamento".

- "Lixo nuclear de difícil desaparecimento; risco de poluição como de Chernobyl".

- "Se a energia nuclear for usada para fins não humanitários haverá, sem dúvida, uma grande alteração no clima".

- "Deve ser melhor para o ambiente que as térmicas".

- "Geração alternativa de energia sem precisar devastar grandes áreas para represas de usinas hidroelétricas".

Na FIG. 4.22, as respostas do grupo 4 são apresentadas. Neste grupo, não houve respostas diretas à questão, foram comentados aspectos relacionados à utilização da energia nuclear (positivos ou negativos) ou foram cometidos erros de informação. Desse grupo, dois parecem ser favoráveis à energia nuclear, com afirmações corretas do ponto de vista técnico.

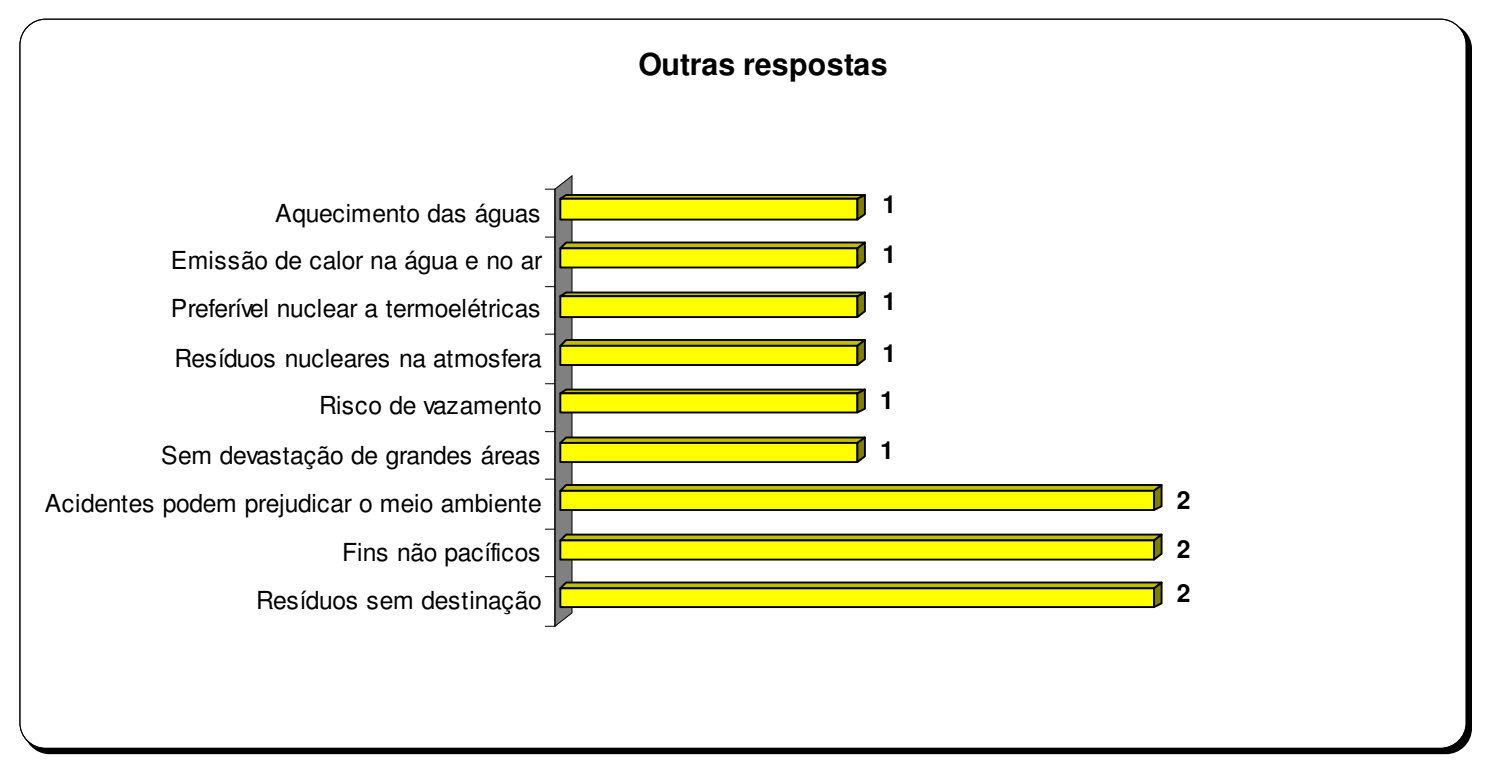

FIGURA 4.22 - Participantes que não responderam de forma direta à questão proposta (Grupo 4) Fonte - Elaborada pela autora

Entre todos os grupos, há nove citações diretas ao rejeito radioativo nas respostas e outras cinco sobre radiações e risco de contaminação. 


\subsubsection{Participação real e participação ideal}

Com relação à participação do público em geral no que diz respeito à conscientização sobre o tema mudanças climáticas, foi solicitado aos respondentes que graduassem de um a cinco o que consideravam ser a participação ideal e a participação real. A nota um significava nenhum interesse e cinco queria dizer muito interesse. A participação ideal reflete a participação considerada necessária e útil, na opinião do respondente. Já a participação real trata-se daquela observada, percebida.

Na FIG. 4.23 está demonstrada a percepção do que foi considerada a participação ideal por parte dos respondentes do sexo masculino, que alcançou média de 4,36. A participação real notada é inferior, em média 2,02. O mesmo gráfico apresenta de forma esquemática os dois resultados.

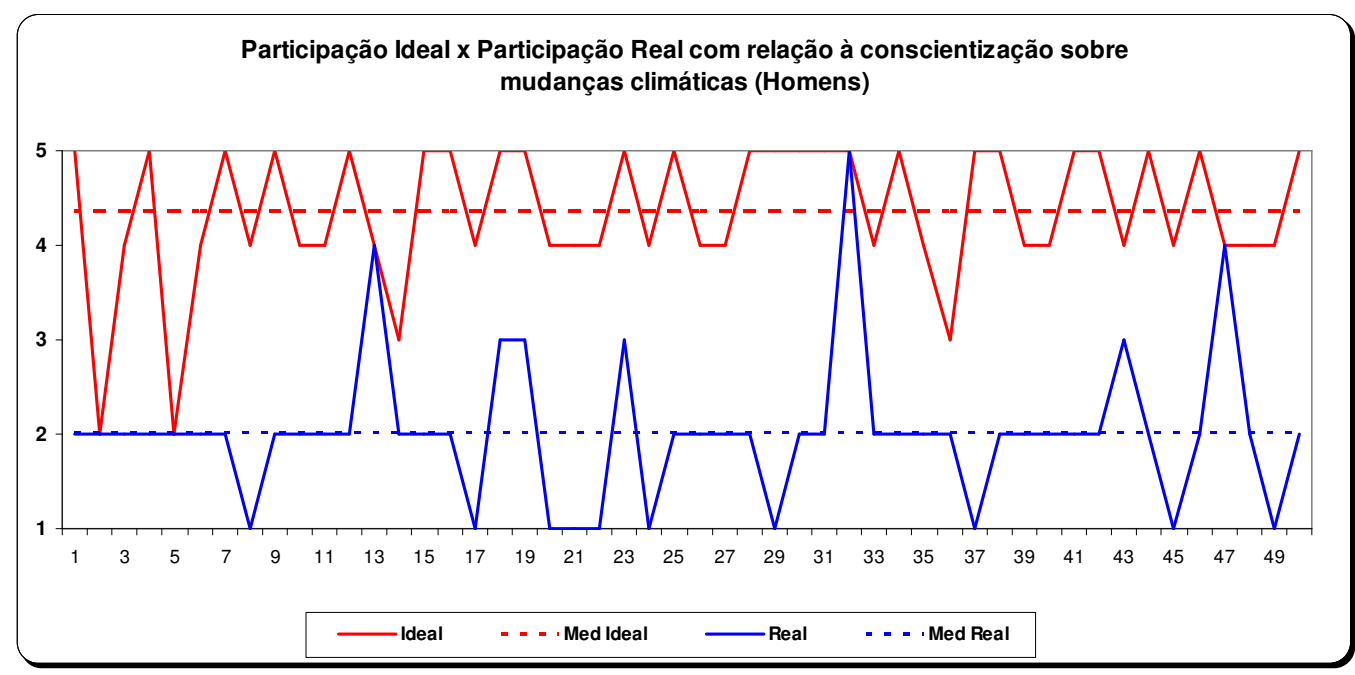

FIGURA 4.23 - Participação ideal versus participação real com relação à conscientização sobre mudanças climáticas - Homens

Fonte - Elaborada pela autora

Na FIG. 4.24 está representada a percepção da participação ideal por parte dos respondentes do sexo feminino, com média de 4,52. A participação real, que também pode ser visualizada no mesmo gráfico, é de 2,04. Houve três participantes cujo sexo não foi identificado. No geral, a média de participação real é de 2,03 e a média da participação ideal é 4,45. 


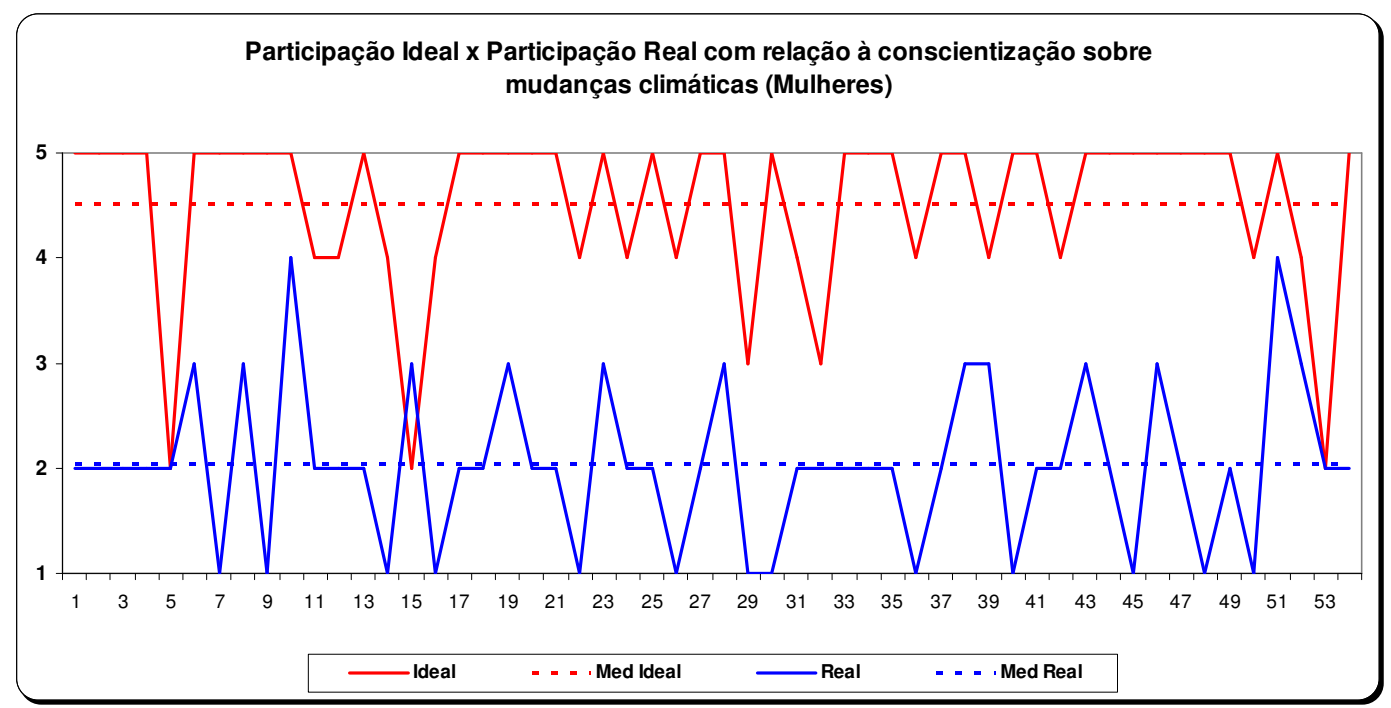

FIGURA 4.24- Participação ideal versus participação real com relação à conscientização sobre mudanças climáticas - Mulheres

Fonte - Elaborada pela autora

Para os respondentes do sexo feminino, a percepção sobre a participação real e a ideal apresenta média ligeiramente superior. Na FIG. 4.25, o comparativo das respostas.

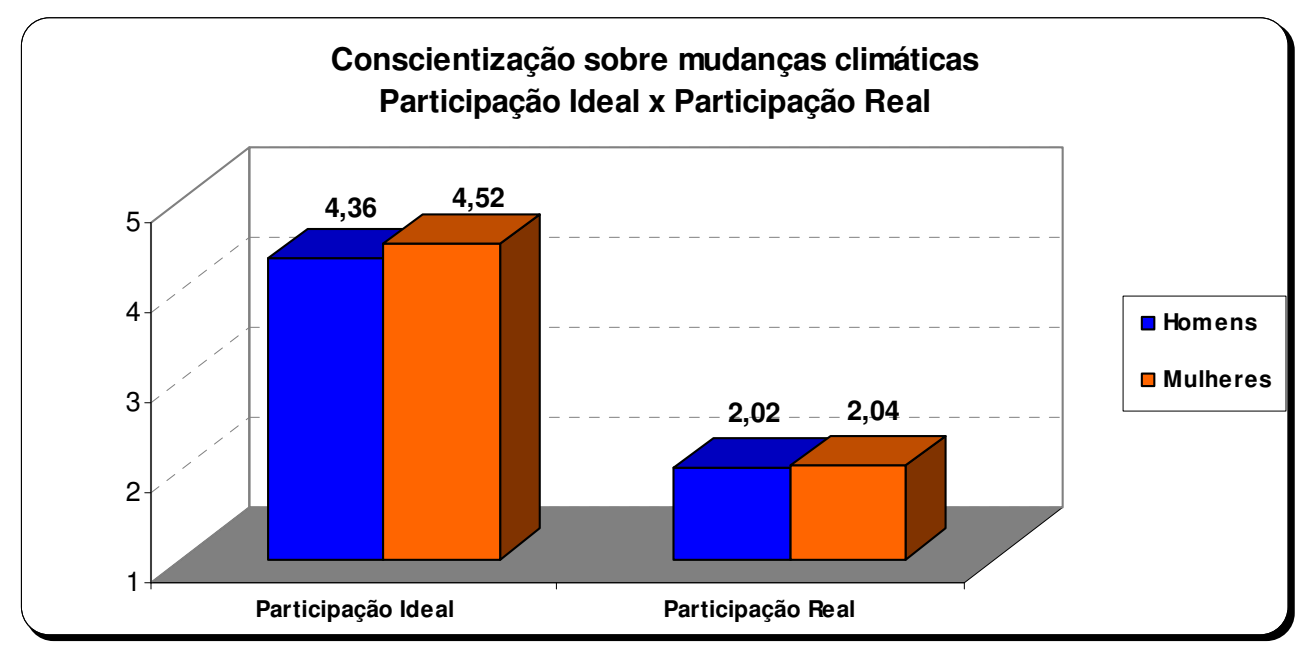

FIGURA 4.25 - Participação ideal versus participação real com relação à conscientização sobre mudanças climáticas - Comparativo

Fonte - Elaborada pela autora

Enfatiza-se ainda que, nesta questão, mais de uma alternativa foi escolhida por alguns dos participantes. 


\section{CONCLUSÃO}

Pelas pesquisas bibliográficas realizadas, é perceptível que a temática ambiental ocupa maior relevância e que as mudanças climáticas mobilizam cientistas das mais diversas áreas, compromissados com a investigação dos fenômenos associados ao tema em suas mais diversas esferas. Os esforços de divulgação científica são urgentes e necessários. Trata-se do delicado equilíbrio entre a relevância dos assuntos a serem abordados e a qualidade com que os mesmos são retratados pela imprensa. Há que se considerar a parte editorial, de opinião, que influencia como os assuntos são recebidos pelo público.

Das análises dos diferentes veículos, nos anos 2006 e 2007, pode-se concluir que na abordagem do tema mudanças climáticas:

- Conceituações erradas do ponto de vista científico predominaram no ano de 2006 ou termos utilizados de forma indevida, como aquecimento global e efeito estufa tomados como sinônimos.

- Com a divulgação dos relatórios do IPCC definições e termos técnicos relacionados às mudanças climáticas foram refinadas $\mathrm{e}$ melhor explicados nos textos.

- Jornais tenderam a se centrar nas negociações políticas, já as revistas apresentaram as conseqüências das mudanças climáticas anunciadas pelos estudos científicos e pelo IPCC e destacaram também atitudes que podem ajudar a "salvar o planeta".

- Em geral, apenas o $\mathrm{CO}_{2}$ é associado ao efeito estufa.

- Quase não se faz menção ao vapor de água para qualquer dos veículos nos anos analisados.

- São poucas as referências ao metano como gás de efeito estufa, por exemplo, em um país de dimensões continentais que tem relação histórica com a atividade agropecuária e tantos desdobramentos desse tema.

- As revistas Veja e Época tiveram cobertura diferente entre elas. A proposta de Época, que possui uma editoria específica de ciência, foi mais esclarecedora e expôs questões ambientais de forma mais próxima das preocupações ambientalistas e das futuras gerações, com aprofundamento dos temas. 
- Reflexões sobre o consumo e estilo de vida foram menos frequentes.

- Foi notório o uso de gráficos e esquemas para explicar de forma didática a questão em todos os veículos.

- Exploração das imagens impactantes sobre extinção de espécies, derretimento de geleiras, seca e fenômenos relacionados a catástrofes predominaram nas revistas, por conta da qualidade gráfica.

- Os alertas e uso de sensacionalismo nas chamadas foram artifícios para destacar o tema.

- Abordagens sobre a realidade nacional, geralmente trazendo questões sobre a Amazônia e os biocombustíveis, foram menos frequentes em relação às questões globais.

- O desmatamento e as queimadas como problemas cruciais a serem combatidos no país na luta contra o aumento de emissões de GEE tiveram papel secundário em termos de destaque, com algumas exceções

- A dualidade ambiente e progresso como valores excludentes ficou marcada especialmente na cobertura de Veja, quando a discussão atual caminha para comprovar que só se obtém progresso com o respeito ao meio ambiente e combatendo a degradação ambiental

- Em um primeiro momento de cobertura, pouco se praticou em termos de jornalismo investigativo e aprofundamento de questões sobre a posição do país no enfrentamento das mudanças climáticas, como a falta de políticas públicas em termos de transporte coletivo ou controle de emissões veiculares nas cidades, por exemplo, ou ainda a falta de fiscalização e políticas eficazes no combate ao desmatamento ou quanto se investe em recursos orçamentários em programas na área de meio ambiente.

- Energia nuclear ocupou espaço coadjuvante na discussão e muitas vezes apareceu com referências a pontos nevrálgicos desta tecnologia: os rejeitos radioativos "sem solução", alto custo e ameaça de proliferação. 
- A matriz energética nacional foi mencionada de forma pouco frequente, apenas citando o Brasil como em posição de vantagem em energias renováveis.

- Nenhuma matéria sobre matrizes energéticas, de forma mais ampla, correlacionando com as perspectivas mundiais.

- Falou-se muito em catástrofes, vítimas, impactos, mas pouco sobre o enfrentamento às mudanças climáticas.

- As negociações internacionais e suas limitações praticamente ficam restritos aos momentos em que ocorrem conferências internacionais.

- Os artigos de opinião nos jornais diários são uma fonte bastante eficaz de contextualização da notícia e funcionaram como complemento para entendimento do tema de forma mais ampla.

- Os espaços em outras editorias ainda eram muito restritos nesses anos de 2006 e 2007, tornando-se um assunto essencialmente da editoria científica, quando a multidisciplinaridade é primordial no tratamento do tema mudanças climáticas.

- Simplificação de conteúdo embora seja desejável, para melhor entendimento, às vezes pode contribuir para raciocínio mais simplista (por exemplo a explicação que países pobres emitem pouco gás carbônico e, portanto, são menos responsáveis pelo aquecimento), não menção a outros contribuintes para o efeito estufa (vapor de água, metano, óxido nitroso, entre outros) e seu potencial de aquecimento.

Duas observações mostram-se pertinentes em termos de análises de abordagem de conteúdo de ciência, em geral, e de mudanças climáticas, em particular:

- O número excessivo de temas e grande diversidade de estudos científicos dificulta a seleção de material, especialmente com as estruturas reduzidas das redações nas áreas de ciência e meio ambiente. 
- As fontes científicas consultadas na elaboração dos textos, a maior interface com a comunidade científica e a diversidade de temas cobertos mostram o potencial do assunto, que deve especialmente se distanciar da abordagem catastrofista. Cientistas, jornalistas e a sociedade devem estar preparados para atuar como participantes desse processo.

Neste estudo foi verificado que o público se informa pela mídia sobre o tema mudanças climáticas, assimilando muitos conteúdos a partir das informações veiculadas; frequentemente confundindo expressões, misturando definições e conceitos científicos. Isto é o resultado de dois fatores: definições e conceitos apresentados de forma equivocada pela própria mídia e exposição a muitos conteúdos noticiosos sem a devida assimilação desse conteúdo. Neste último caso, nota-se a deficiência de conceitos científicos por parte do público, resultado de problemas estruturais do ensino na sociedade atual, especialmente no que diz respeito às ciências de modo geral. Percebe-se o registro de conceitos intuitivos e informações parciais sobre o tema. As conseqüências das mudanças climáticas anunciadas pelos estudos científicos e amplamente divulgadas desde 0 último AR4 estão marcadas no imaginário dos participantes, que estabeleceram relações essencialmente com catástrofes e eventos climáticos de graves proporções. Afinal, a catástrofe climática iminente tornou-se uma grande história.

$O$ interesse por temas relacionados à ciência e meio ambiente mostrou-se elevado, sendo o interesse específico por meio ambiente $13 \%$ maior em relação à ciência de modo geral. Vale destacar que fatores econômicos e políticos influenciam a percepção sobre os problemas ambientais.

Verificou-se também que o tema mudanças climáticas tem sido tomado como sinônimo de aquecimento global e relacionado fortemente às consequências apontadas nos relatórios do IPCC. Também predomina a visão de que as mudanças climáticas se devem à ação antropogênica. Frequentemente são relacionadas às emissões crescimento populacional, desmatamento, degradação ambiental e poluição, mas é praticamente irrisório o número de citações aos padrões de consumo. A ideia de que o crescimento populacional leva ao "acúmulo de poluição" e "gases" não muito bem conceituados (embora as citações ao $\mathrm{CO}_{2}$ predominem) está presente nas respostas de forma direta ou indireta. 
$\mathrm{Na}$ percepção do público pesquisado com relação às ações de combate às mudanças climáticas, um contingente significativo afirmou desconhecer tais medidas: 25\% para ações do país e 17\% para ações em âmbito mundial. Outros 6\% afirmaram não estar sendo feito nada em relação ao combate às mudanças climáticas no país. As ações mais lembradas no contexto nacional são o combate ao desmatamento e o uso de renováveis ou combustíveis alternativos (referências ao etanol e uso de biocombustíveis), respectivamente por $21 \%$ e $12 \%$, totalizando $33 \%$ do público participante. No contexto internacional, as ações mais lembradas são o Protocolo de Quioto (18\%) e conferências, reuniões e discussões (17\%), citados de maneira genérica, totalizando juntos $35 \%$ das respostas obtidas.

Para o público pesquisado, há desconhecimento por parte de quase metade (48\%) sobre a relação entre mudanças climáticas e energia nuclear. 0 público que afirmou que energia nuclear não contribui para as mudanças climáticas por não envolver a queima de combustíveis fósseis é de $27 \%$, dentre os quais $1 / 3$ destaca aspectos desfavoráveis da componente nuclear ou riscos intrínsecos, mesmo considerando a energia nuclear como opção. Para 14\% a energia nuclear é prejudicial ou contribui para as mudanças climáticas, apresentando as respostas desse grupo incorreções técnicas e associações inexistentes (resíduo da usina ocasionando mudanças climáticas). Um total de $11 \%$ não respondeu de forma direta à questão; comentou aspectos relacionados (positivos ou negativos) ou cometeu erros de informação.

Pode-se depreender dos resultados obtidos que a tecnologia nuclear, que envolve preconceitos, legado de guerras e destruição não é vista de forma positiva pelos participantes que souberam responder à questão, mas por outro lado há um público expressivo que desconhece associação entre nuclear e mudanças climáticas e que precisa receber informações sobre as possibilidades desta tecnologia para poder compreender e se posicionar com base em informações bem fundamentadas.

Pela análise de mídia, no período estudado, as menções à tecnologia nuclear ocuparam papel secundário e foram geralmente acompanhadas de advertências sobre os riscos da tecnologia. 
Vale observar que a pressa na leitura ou leitura superficial, devido ao excesso de informações a que estão expostas as pessoas na sociedade atual tende a facilitar a distorção na compreensão de determinados assuntos.

Repensando o papel da ciência e a abordagem do tema mudanças climáticas, é imprescindível destacar que a melhor técnica não pode estar dissociada da comunicação eficiente, capaz de sensibilizar tomadores de decisão e mobilizar as pessoas. Os cidadãos da aldeia global precisar vencer obstáculos e as ciências precisam interligadas, buscar soluções. Não há mais espaço para saberes estanques, compartimentados. Surgem novos questionamentos relacionados à complexa interação homem e meio ambiente. Há um grande apelo às causas de maior mobilização. Em um mundo em que o valor da imagem e a exigência pela informação e entretenimento é tão grande, a velocidade, a fragmentação do discurso trazem novas exigências à ciência institucionalizada.

A participação real das pessoas no que diz respeito à conscientização sobre mudanças climáticas mostrou-se menor do que elas acreditam que seria 0 necessário. Frente aos graves problemas ambientais que se enfrenta seria preciso muito mais conscientização, participação, engajamento. Só assim as ações necessárias por parte dos cidadãos e a devida cobrança de atitudes governamentais para combater a degradação ambiental se concretizam em fatos em prol do homem e do ambiente em que vive.

Tal grau de participação e politização na sociedade brasileira ainda está muito aquém do desejável. Mas o que estaria faltando para a realidade brasileira? Mais informação, legislação específica, ousada e capaz de conter emissões? Fiscalização? Aplicação de penalidades? Algumas leis já existem, mas precisam ser postas em prática. A pesquisa científica pode evoluir, mas sem as devidas ações ela é vazia, apenas um alerta ou um prenúncio de catástrofes e mais degradação. Mobilizar as pessoas é tarefa árdua, difícil, mas sem informação, sem sensibilizar a opinião pública é impossível obter resultados efetivos, eficazes, duradouros.

Como as questões envolvidas com a ameaça das mudanças climáticas globais são muito profundas, sérias, envolvendo novos valores, mudança de mentalidade e conceitos pouco praticados na sociedade atual (altruísmo, bem estar coletivo) é necessário uma verdadeira revolução no modo de pensar e agir. Mudanças de paradigmas que o homem não está preparado para enfrentar. 
Diante da ameaça, animais lançam mão de mecanismos de defesa, mas mesmo assim se extinguem. Será que o homem não usará sua inteligência para mudar o modo como conduz a sociedade atual?

A cobertura de imprensa nos anos estudados foi muito focada nas pesquisas e consequências das mudanças climáticas. Questões sobre política ambiental ficaram de fora da cobertura de modo geral, algo sobre percepção da opinião pública em relação ao assunto também foi tratada de forma pontual. As possibilidades do tema em outras editorias foram pouco exploradas nos anos estudados, especialmente em 2007, marcado pela efervescência do debate, por ocasião da divulgação de relatórios do IPCC.

É fundamental a abordagem cautelosa porém enfática, na medida certa para prover o cidadão com informações de qualidade, que permitam suscitar críticas, gerar mobilização. Os relatórios do IPCC e a cobertura realizada no período permitiu esse exercício de equilíbrio entre o alarmismo e a cautela, um dilema que também o IPCC tenta conciliar entre os cientistas que compõem o painel.

É possível criar boas histórias, baseadas em boas apurações e conteúdos inovadores. As pautas melhor trabalhadas, com criatividade e informação de qualidade, podem trazer abordagens diferenciadas. Nas revistas de informação, com um tempo de produção maior do conteúdo noticioso, esse trabalho pode ser mais fácil. A exigência de blogs, materiais para internet e outras linguagens promovendo a interação com o público podem ser encaradas como um agente revolucionário, que realmente auxilie na produção de novos conteúdos. O jornalismo de investigação, a possibilidade de ouvir várias fontes e de trazer o leitor como agente dessa construção do processo pode trazer muitos ganhos.

Ao mesmo tempo, a ciência e as instituições científicas se adaptam aos novos tempos. Certamente podem se beneficiar dessa interatividade advinda com as novas tecnologias, desde que criem as bases para um novo patamar para a ciência e o processo de produção do conhecimento científico, em favor dos atores para os quais eles devem estar realmente destinados. Também é importante que seja restabelecido o diálogo que falta entre os cientistas e o público, pelo distanciamento entre a academia e o conhecimento tradicional. 
Diante da crise abrem-se possibilidades e alternativas. A crise climática pode ser mais um momento histórico para a busca de soluções para novos modelos de desenvolvimento, para uma visão holística, mais harmônica, capaz de possibilitar ao homem se enxergar como ele próprio parte da natureza. 


\section{TRABALHOS FUTUROS}

- Aplicar questionários a respeito de mudanças climáticas para outros públicos, visando ao acompanhamento sobre a compreensão do tema.

- Reaplicar os questionários para realizar um novo diagnóstico da percepção a respeito do tema.

- Investigar a percepção de riscos sobre as mudanças climáticas para diferentes públicos, comparando inclusive com a percepção de risco nuclear, se ela é alterada pela ameaça climática.

- Investigar a disposição do público em mudar suas atitudes no que diz respeito a ações que impactam o meio ambiente e contribuem para as mudanças climáticas (questões sobre consumo, educação ambiental e outras).

- Investigar como são percebidos aspectos sobre mitigação e adaptação às mudanças climáticas. 


\section{APÊNDICE A - Questionário destinado aos cientistas}

1. Identificação

Nome:

Instituição:

Função exercida:

2. Como você avalia a compreensão das pesquisas relacionadas ao tema mudanças climáticas por parte da imprensa?

3. Houve mudança com relação ao entendimento dos temas por parte da imprensa desde a divulgação do último relatório do Painel Intergovernamental sobre Mudanças Climáticas (IPCC)? De que forma?

4. Destacaria alguma reportagem com a qual colaborou como fonte de informação e que tenha chamado sua atenção por ter sido um exemplo diferenciado na cobertura do tema mudanças climáticas?

5. No contato com os jornalistas, consegue perceber alguma deficiência no entendimento de conceitos ligados ao tema mudanças climáticas ou do conteúdo de pesquisas científicas que pautam as entrevistas?

6. Em caso afirmativo, com que freqüência

Sempre ( ) Na maioria das vezes ( ) Raramente ( )

7. Quais dos seguintes pontos positivos você percebe no contato com os jornalistas que cobrem ciência e meio ambiente

( ) Leitura prévia do tema tratado em papers e informações científicas

( ) Entendimento dos conceitos

( ) Bom nível de informação

( ) Abordagens diferenciadas (pontos de vista interessantes e originais)

( ) Boa qualidade dos textos publicados

( ) Poucos erros relacionados a conceitos técnicos

8. Como pesquisador, há dificuldades no contato com a imprensa? Quais seriam?

9. Quais os maiores desafios na cobertura pela imprensa do tema mudanças climáticas?

10. Citar um ou mais exemplos de erros encontrados na cobertura do tema mudanças climáticas. 
11. Nas entrevistas, com que freqüência as perguntas dos jornalistas são mais voltadas a

\begin{tabular}{|l|l|l|l|}
\hline & Sempre & $\begin{array}{l}\text { Na maioria } \\
\text { das vezes }\end{array}$ & Raramente \\
\hline $\begin{array}{l}\text { Políticas públicas de combate ao aquecimento } \\
\text { global }\end{array}$ & & & \\
\hline $\begin{array}{l}\text { Catástrofes ou desastres naturais } \\
\text { relacionados às alterações climáticas }\end{array}$ & & & \\
\hline $\begin{array}{l}\text { Medidas de mitigação e adaptação } \\
\text { relacionadas às alterações climáticas }\end{array}$ & & & \\
\hline $\begin{array}{l}\text { Dúvidas técnicas envolvendo conceitos } \\
\text { básicos relacionados ao tema }\end{array}$ & & & \\
\hline $\begin{array}{l}\text { Dúvidas técnicas envolvendo conceitos } \\
\text { complexos relacionados a pesquisas sobre o } \\
\text { tema }\end{array}$ & & & \\
\hline $\begin{array}{l}\text { Participação da sociedade nas discussões } \\
\text { sobre o tema }\end{array}$ & & & \\
\hline $\begin{array}{l}\text { Abordagem política do tema mudanças } \\
\text { climáticas }\end{array}$ & & & \\
\hline $\begin{array}{l}\text { Abordagem econômica do tema mudanças } \\
\text { climáticas }\end{array}$ & & & \\
\hline
\end{tabular}

Caso tenha interesse em registrar algum comentário adicional: 


\section{APÊNDICE B - Questionário destinado aos jornalistas}

1. Identificação

Nome:

Órgão de imprensa:

Há quanto tempo trabalha para o veículo:

Há quanto tempo trabalha como jornalista:

Área que cobre no periódico:

Função:

2. Há quanto tempo cobre questões ambientais:

3. Há quanto tempo cobre o assunto mudanças climáticas:

4. Como você se preparou para a cobertura do tema mudanças climáticas?

5. Participou de algum curso específico? Em caso afirmativo, quando ? Esse evento ocorreu no país ou no exterior?

6. Assina algum periódico específico voltado ao tema mudanças climáticas ou recebe regularmente informes de instituição científica?

7. Especificamente na cobertura do tema mudanças climáticas, acessa papers ou relatórios científicos:

Sempre ( ) Na maioria das vezes ( ) Raramente ( )

8. Com que freqüência acessa papers e publicações científicas na cobertura geral de ciência?

9. É ligado a alguma sociedade ou associação nacional ou internacional de jornalismo científico?

10. Quais as maiores dificuldades ou facilidades que encontra no contato com os cientistas?

Use o espaço abaixo caso tenha interesse em registrar algum comentário adicional: 


\section{APÊNDICE C - Questionário destinado ao público}

Nome:

Formação/ Atividade:

Cursando:

Em que instituição:

Idade:

E-mail para contato:

Orientações para o preenchimento: Caso desconheça algum dos conceitos ou não saiba responder algumas das questões, escreva desconheço ou não sei responder, deixando claro que leu a pergunta.

1. Qual o seu interesse por ciência e temas relacionados à ciência?

Marque com X uma das colunas graduadas de um a cinco, onde um significa

nenhum interesse e cinco significa muito interesse pelo assunto:

\begin{tabular}{|c|c|c|c|c|}
\hline \multicolumn{5}{|c|}{ Grau de interesse pelos temas de } \\
ciência
\end{tabular}

2. Qual o seu interesse pelas questões ambientais?

Marque com X uma das colunas graduadas de um a cinco, onde um significa nenhum interesse e cinco significa muito interesse pelo assunto:

\begin{tabular}{|c|c|c|c|c|}
\hline \multicolumn{5}{|c|}{$\begin{array}{l}\text { Grau de interesse pelos temas } \\
\text { relacionados ao meio ambiente }\end{array}$} \\
\hline 1 & 2 & 3 & 4 & 5 \\
\hline & & & & \\
\hline
\end{tabular}

3. Você assina jornais e revistas impressas?

( ) Sim ( ) Não

Quais?

4. O que você sabe sobre mudanças climáticas?

5. Cite duas palavras das quais lembra imediatamente quando pensa no tema mudanças climáticas.

6. Qual seu principal meio de acesso a informações sobre o tema mudanças climáticas?

7. Como você define o termo efeito estufa? 
8. Conhece algo que o Brasil está fazendo no combate às mudanças climáticas?

9. Conhece algo que está sendo realizado em âmbito mundial no combate às mudanças climáticas?

10. Você percebe alguma associação entre energia nuclear e mudanças climáticas? Qual (is)?

11. Em relação à participação do público em geral com relação à conscientização sobre o tema mudanças climáticas, o que você considera participação ideal (necessária) e participação real (hoje existente)?

Marque com $X$ uma das colunas graduadas de um a cinco, onde um quer dizer nenhum interesse e cinco quer dizer muito interesse.

\begin{tabular}{|c|c|c|c|c|}
\hline Partic & & ária & & dera \\
\hline 1 & 2 & 3 & 4 & 5 \\
\hline & & & & \\
\hline
\end{tabular}

\begin{tabular}{|c|c|c|c|c|}
\hline \multicolumn{5}{|c|}{ Participação real (a que você percebe, observa) } \\
\hline 1 & 2 & 3 & 4 & 5 \\
\hline & & & & \\
\hline
\end{tabular}




\section{REFERÊNCIAS BIBLIOGRÁFICAS}

AFP - Agência France Press. México quer trazer excluídos na COP-15 para as discussões climáticas. UOL, São Paulo, 12 ago. 2010. Disponível em: <http:// noticias.uol.com.br/ultimas-noticias/afp/2010/08/12/mexico-quer-trazerexcluidos-na-cop-15-para-as-discussoes-climaticas.jhtm>. Acesso em: 18 jul. 2010.

AíMOLA, L.A.L. Cascatas de incertezas, impactos climáticos perigosos e negociações internacionais sobre mudança de clima global: um modelo exploratório. 2006. Tese (Doutorado) - Universidade de São Paulo, São Paulo.

ALMEIDA, J. A problemática do desenvolvimento sustentável. In: BECKER, D.F. (Org.). Desenvolvimento sustentável: necessidade e/ou possibilidade? 4. ed. Santa Cruz do Sul: EDUNISCC, 2002.

AMBIENTE BRASIL. Resolução do Conama que obriga inspeção veicular é publicada no DOU. Disponível em:

<http://noticias.ambientebrasil.com.br/clipping/2009/11/27/50074-resolucao-doconama-que-obriga-inspecao-veicular-e-publicada-no-dou.html>. Acesso em: 18 jul. 2010.

ANDI. Agência de Notícias dos Direitos da Infância. Mudanças climáticas na imprensa brasileira. Brasília, set. 2009. Disponível em:

<http://www.scribd.com/full/19618824?access_key=key1fandna8pq7fwype2fz>. Acesso: 6 jul. 2010.

AZEVEDO, J.C. (Org.). Escrevendo pela nova ortografia: como usar as regras do novo acordo ortográfico da língua portuguesa. São Paulo: Publifolha, 2008.

BARBIERI, J. C. Gestão ambiental empresarial: conceitos, modelos e instrumentos. 2. ed. atual. e ampl. São Paulo: Saraiva, 2007.

BARROS, S.M. Base científica para a compreensão do aquecimento global. In: VEIGA, J.E. (Org.). Aquecimento global: frias contendas científicas. São Paulo: SENAC, 2008.

BIS - Department for Business Innovation and Skills. Science and the media: securing the future, Jan. 2010. Disponível em:

<http://interactive.bis.gov.uk/scienceandsociety/site/media/files/2010/01/Scienceand-the-Media-Securing-the-Future.pdf>. Acesso em: 12 ago. 2010. 
BRAGA, B.; HESPANHOL, I.; CONEJO, J.; MIERZWA, J.C.; BARROS, M.T.L. SPENCER, M.; PORTO, M.; NUCCI, N.; JULIANO, N.; EIGER, S. Introdução à engenharia ambiental. 2. ed. São Paulo: Prentice Hall, 2005.

BRASIL. Ministério da Ciência e Tecnologia (MCT). Departamento de popularização e difusão da C\&T. Secretaria de Ciência e Tecnologia para Inclusão Social. Percepção pública da ciência e tecnologia. Brasília: CDN Estudos e Pesquisas, 2007. Disponível em:

<http://www.mct.gov.br/upd_blob/0013/13511.pdf>. Acesso em: 5 jul. 2010.

BRASIL. Ministério da Ciência e Tecnologia (MCT). Inventário Brasileiro das Emissões e Remoções Antrópicas de Gases de Efeito Estufa - Informações Gerais e Valores Preliminares. Brasília, 30 nov. 2009. Disponível em:

<http://www.mct.gov.br/upd_blob/0207/207624.pdf >. Acesso em: 8 ago. 2010.

CONTROLAR, 2008. Programa de inspeção e manutenção de veículos em uso I/M - SP. Disponível em:

$<$ http://www.controlar.com.br/empresa_programa.php?tipo=3>. Acesso em: 18 jul. 2010.

CRESPO, Samyra. Uma visão sobre a evolução da consciência ambiental no Brasil nos anos 1990. In: Meio ambiente no século 21... 4. ed. Campinas: Armazém do Ipê, 2005.

D’ AMÉLIO, M. T. S. Estudo de gases de efeito estufa na Amazônia. 2006. Dissertação (Mestrado) - Instituto de Pesquisas Energéticas e Nucleares, São Paulo.

DANTAS, E. O Imaginário do aquecimento global. 2009. Dissertação (Mestrado) - Universidade de São Paulo, São Paulo.

DIAS, G. F. Educação ambiental - princípios e práticas. 9. ed. São Paulo: Gaia, 2004.

DIAS, G. F. Pegada ecológica e sustentabilidade humana. São Paulo, Gaia, 2002.

DOULTON, H., BROWN, K. Ten years to prevent catastrophe? Discourses of climate change and international development in the UK press. Global Environmental Change, v. 19, p. 191-202, 2009.

DUARTE, M.Y.M. Comunicação e cidadania. In: DUARTE, J. (Org.). Comunicação pública: estado, mercado, sociedade e interesse público. São Paulo: Atlas, 2007. 
FMI ambiental' nas metas de redução. Folha de S. Paulo, 16 ago. 2010.

FARIA, A. M. Imprensa e interesse público. In: DUARTE, J. (Org.). Comunicação pública: estado, mercado, sociedade e interesse público. São Paulo: Atlas, 2007.

GOLDEMBERG, J.; LUCON, O. Energia, meio ambiente \& desenvolvimento. 3. ed. rev. ampl. São Paulo: Edusp, 2008.

IBGE - Instituto Brasileiro de Geografia e Estatística. Indicadores de desenvolvimento sustentável Brasil 2010. Rio de Janeiro, 2010. Disponível em: <http://www.ibge.gov.br/home/geociencias/recursosnaturais/ids/ids2010.pdf>. Acesso em: 13 set. de 2010.

IBGE - Instituto Brasileiro de Geografia e Estatística. Pesquisa nacional de saneamento básico 1989/2000. Rio de Janeiro, 2002. Disponível em: <http://www.ibge.gov.br/home/estatistica/populacao/condicaodevida/pnsb/ pnsb.pdf>. Acesso em: 12 set. 2010.

IBGE - Instituto Brasileiro de Geografia e Estatística. Vocabulário básico de recursos naturais e meio ambiente. 2. ed. Rio de Janeiro, 2004. Disponível em: <http://www.ibge.gov.br/home/presidencia/noticias/vocabulario.pdf>. Acesso em: 12 set. 2010.

IGAMI, M.P.Z.; ZARPELON, L.M.C. (Org). Guia para a elaboração de dissertações e teses: preparado para orientação dos alunos de pós-graduação do IPEN. São Paulo: IPEN, Divisão de Informação e Documentação Científicas, 2002. Disponível em:

$<$ https://www.ipen.br/conteudo/upload/200609111605540.guia_teses.pdf>. Acesso em: 13 de ago. de 2010.

IIDS - International Institute for Sustainable Development. A brief history of the UNFCCC and the Kyoto Protocol. Earth Negotiations Bulletin. v. 12, n. 472, June 14, 2010. Disponível em: <http://www.iisd.ca/vol12/enb12472e.html>. Acesso em: 16 jun. 2010.

IPCC - Intergovernmental Panel on Climate Change. Climate Change 2007: The physical science basis. Contribution of Working Group I to the Fourth Assessment Report of the Intergovernmental Panel on Climate. Cambridge University Press, Cambridge, United Kingdom and New York, NY, USA, 2007, 996 pp. Disponível em: < http://www.ipcc.ch/ipccreports/ar4-wg1.htm>. Acesso em 28 abr. 2010.

IPCC - Intergovernmental Panel on Climate Change. Climate Change 2007: synthesis report. Contribution of Working Groups I, II and III to the Fourth Assessment Report of the Intergovernmental Panel on Climate Change [Core Writing Team, Pachauri, R.K and Reisinger, A. (eds.)]. IPCC, Geneva, Switzerland, 104 pp. Disponível em: 
$<\mathrm{http}: / /$ www.ipcc.ch/publications_and_data/ar4/syr/en/contents.html>. Acesso em 28 abr. 2010.

IPCC - Intergovernmental Panel on Climate Change. Carbon dioxide capture and storage. Prepared by Working Group III of the IPCC [Metz, B., O. Davidson, H. C. de Coninck, M. Loos, and L. A. Meyer (eds.)]. New York: Cambridge, 2005.

KITCHER, P. The climate change debates. Science, v. 328, p. 1230-1234, n. 5983, 4 June 2010.

LEAL FILHO, W. Universities and climate change. Germany: Springer, 2010. Disponível em:

$<$ http://books.google.com.br/books?id=sX2LG0pXV3AC\&printsec=frontcover\&dq= climate+change+at+universities+leal\&source=bl\&ots=KFDgZSQxpV\&sig=yvey4SL 8MWPgveePQ93SA9F0EEE\&hl=pt-

BR\&ei=ygHRTPziAc2r8AaOprGtDA\&sa=X\&oi=book_result\&ct=result\&resnum= $5 \& v e d=0 C D I Q 6 A E w B A \# v=0 n e p a g e \& q \& f=$ false $>$. Acesso em: 20 jul. 2010.

McCORMICK, J. Climate change and the nuclear option. Environmental Practice v. 9 , n.1, March 2007

MOLION, L.C.B. Aquecimento global: uma visão crítica. In: VEIGA, J.E. (Org.). Aquecimento global: frias contendas científicas. São Paulo: SENAC, 2008.

MOLS, B. Understanding scientific uncertainty. World Federation of Science Journalists, Mar. 2010. Disponível em:

$<$ http://www.wfsj.org/blogs/2010/03/08/understanding-scientific-

uncertainty/?utm_source=feedburner\&utm_medium=feed\&utm_campaign=Feed\% 3A+WfsjBlog+\%28WFSJ\%27s+Blog\%29>. Acesso em: 25 jul. 2010.

MORAIS, R. Educação, mídia e meio ambiente. Campinas, SP: Alínea, 2004.

NEWPORT, F. Americans: Economy Takes Precedence Over Environment. Gallup, Princeton, Mar. 2009. Disponível em: $<$ http://www.gallup.com/poll/116962/Americans-Economy-Takes-PrecedenceEnvironment.aspx >. Acesso em: 16 jul. 2010.

OLIVEIRA, F. Jornalismo científico. São Paulo: Contexto, 2002.

PARRA FILHO, D.; SANTOS, J.A. Metodologia científica. São Paulo: Futura, 2003, 6.ed.

PNUD. Relatório de desenvolvimento humano 2007/2008. Disponível em: <http://www.pnud.org.br/arquivos/rdh/rdh20072008/ hdr_20072008_pt_complete.pdf>. Acesso em: 10 mai. 2010. 
RAMPAZZO, S. E. A questão ambiental no contexto do desenvolvimento econômico. In: BECKER, D.F. (Org.). Desenvolvimento sustentável: necessidade e/ou possibilidade? 4. ed. Santa Cruz do Sul: EDUNISCC, 2002.

REIGOTA, M. A contribuição da ciência ao desenvolvimento com base ecologista. In: BECKER, D.F. (Org.). Desenvolvimento sustentável: necessidade e/ou possibilidade? 4. ed. Santa Cruz do Sul: EDUNISCC, 2002.

SATTERTHWAITE, D. The implications of population growth and urbanization for climate change. Environment and Urbanization, v. 21, p. 545-567, n. 2, October 2009.

SHANAHAN, M. Time to adapt? Media coverage of climate change in nonindustrialised countries. In: BOYCE, T.; LEWIS, J. (Ed.). Climate change and the media. United Kingdom, UK: Peter Lang, Aug. 2009. Disponível em:

http://www.iied.org/pubs/pdfs/GO2512.pdf. Acesso: 6 jul. 2010.

STEPHENSON, J. Population dynamics and climate change: what are the links?. Journal Public Health, v. 32, p. 150-156, June 2010.

STOCKER, T.; PLATTNER, G.K. The Physical Science Basis of Climate Change: latest findings to be assessed by WGI I in AR5. In: UNITED NATIONS CLIMATE CHANGE CONFERENCE, 15, Dec. 8, 2009, Copenhague.( IPCC Side event IPCC findings and activities and their relevance for the UNFCCC Process). Disponível em:

$<$ http://www.ipcc.ch/pdf/presentations/COP15presentations/stocker09unfccc Copenhagen_delegate_new.pdf>. Acesso em: 12 mai. 2010.

TRIGUEIRO, A. (Coord.). Meio ambiente no século 21: 21 especialistas falam da questão ambiental nas suas áreas de conhecimento. 4. ed. Campinas: Armazém do Ipê, 2005.

VARGAS, P.R. O insustentável discurso da sustentabilidade. In: BECKER, D.F. (Org.). Desenvolvimento sustentável: necessidade e/ou possibilidade? 4. ed. Santa Cruz do Sul: EDUNISCC, 2002.

WALKER, G.; KING, S. D. Tradução: Caroline Chang. O tema quente: como combater o aquecimento global e manter as luzes acesas. Rio de Janeiro: Objetiva, 2008.

WB - World Bank. Country partnership strategy progress report for the federative republic of brazil for the period 2008-2011. March 11, 2010. Disponível em: <http://siteresources.worldbank.org/BRAZILINPOREXTN/Resources/3817166- 
1220388091471/CPS_CountryProgressReport_2008_2011.pdf>. Acesso em: 18 ago. 2010

WEC - World Energy Council - Comitê Brasileiro. Eficiência energética: uma visão mundial. Rio de Janeiro, Ago. 2004. Disponível em:

<http://www.worldenergy.org/documents/eficincia_energtica_mundial.pdf>. Acesso em: 8 dez. 2009.

WEC - World Energy Council. Energy and Climate Change. London, June 2007. Disponível em:

$<$ http://www.worldenergy.org/documents/wec_study_energy_climate_change_onli ne.pdf>. Acesso em: 12 mai. 2010.

WEC - World Energy Council. Pursuing sustainability: 2010 assessment of country energy and climate policies. London, 2010. Disponível em:

<http://www.worldenergy.org/documents/assessment_2010_full_report_1.pdf>. Acesso em: 2 set. 2010.

WEC - World Energy Council. World energy and climate policy: 2009 assesment. London, 2009. Disponível em:

$<$ http://www.worldenergy.org/documents/report_final_3.pdf>. Acesso em: 10 jun. 2010.

WOLCOTT, S.; SENGUPTA, A. Learning for change in public, educational and other science organisations: embedding greater public engagement. Fev. 2010. Disponível em:

$<$ http://interactive.bis.gov.uk/scienceandsociety/site/all/files/2010/02/Senguptaand-Wolcott-Organisational-Change-FINAL1.pdf>. Acesso em: 28 jul. 2010.

XAVIER, M.E.R.; KERR, A.S. A análise do efeito estufa em textos paradidáticos e periódicos jornalísticos. Caderno Brasileiro de Ensino de Física, São Paulo, v.21, n.3, dez. 2004. Disponível em:

$<$ <ttp://homologa.ambiente.sp.gov.br/proclima/artigos_dissertacoes/ artigos_portugues/analisedoefeitoestufaemtextosjornalisticos.pdf>. Acesso em: 20 nov. 2009. 